Pues no soy mujer. The Upheaval of Singularity in Sor Juana Inés de la Cruz.

Valeria Stabile 


\section{Pues no soy mujer. The Upheaval of Singularity in Sor Juana Inés de la Cruz.}

Pues no soy mujer. De omwenteling van singulariteit in Sor Juana Inés de la Cruz.

(met een samenvatting in het Nederlands)

PROEFSCHRIFT

ter verkrijging van de graad van doctor aan de Universiteit Utrecht op gezag van de rector magnificus,

prof. dr. H.R.B.M. Kummeling,

ingevolge het besluit van het college voor promoties in het openbaar te verdedigen op VRIJDAG 12 NOVEMBER 2021

DES OCHTENDS TE 10.15 UUR

door

\section{Valeria Stabile}

geboren op 29 december 1985

te Castrovillari, Italië 
Promotoren: Prof. dr. R. Buikema

Prof. dr. M. J. Rodrigo Mora

Dr. K. Thiele

Prof. dr. E. Balletta

The degree is awarded as part of a Joint Doctorate with Alma Mater Studiorum University of Bologna, (Bologna, Italy) 
Table of contents

ENGLISH SUMMARY

NEDERLANDSE SAMENVATTING............................................................................................... 7

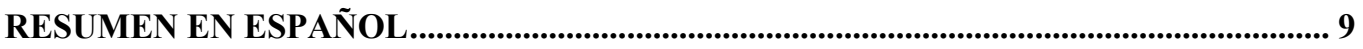

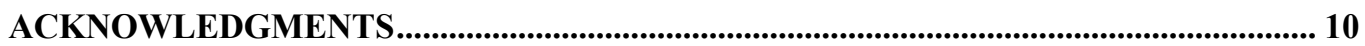

INTRODUCTION. SOR JUANA: SEDUCTION, POLYSEMY, AND REVOLUTION.... 12

FIRST CHAPTER. THE SEXUAL REVOLUTION OF THE SUBJECT: FROM EL

NEPTUNO ALEGÓRICO TO PRIMERO SUEÑO

1. Introduction: How to Read Sor Juana’s TeXts Without Separating Sex from SUBJECT?

2. Which SubJeCt SPEAKS IN SOR JUANA's EL NEPTUNO ALEGÓRICO? 36

3. THE LABYRINTH AND THE BAROQUE FoldS OF THE SIGN.............................................. 42

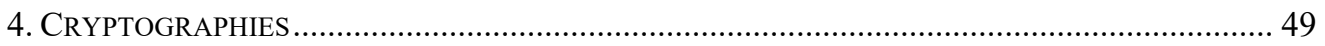

5. The Fluidification of the SubStance of the SubJeCt ................................................ 53

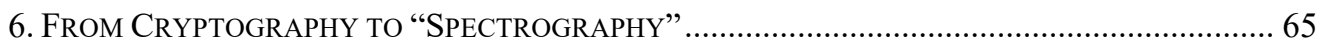

7. Primero Sueño: The Disjunction of Soul from Body and Mind, And the

ENTANGLEMENT OF THE SUBJECT AND SEX

SECOND CHAPTER. SOR JUANA AND THE SEXISTENCE OF BODIES.................... 83

1. INTRODUCTION. DeFINING SEX: THE OTHER ANSWER

2. Moving the AtTention from LA RESPUESTA to RESPONDIENDO A UN CABALLERO DEL PERÚ 90

3. Pues no soy mujer: The Denial of Belonging in Respondiendo a UN CABALLERo DEL PERÚ 94

4. "She Should Become a MaN": SeX as A Bodily Act In Sor JuAna And JeAn-LuC NANCY. 106

5. SeX, S'EXISTENCE, AND SEXISTANCE 
6. Why Is THE Question of SEX In SOR JuAna InÉS DE LA CRUZ’S TEXTs So IMPORTANT TODAY?

THIRD CHAPTER. THE PHOENIX: RESISTING THE NORMS OF LANGUAGE .... 131

1. Introduction: The Phoenix And the Impossible Space of LifE DeAth 131

2. INTRODUCING AND CONTEXTUALIZING ROMANCE QUE RESPONDIÓ NUESTRA POETISA ........ 140

3. The Rara Avis: The Phoenix AS A UniQue Creature ................................................. 145

4. The Phoenix as the Metaphor of “Life DeAth” ................................................... 155

5. QUE HAYA FÉNIX QUE NO BARBE: Writing THE PHOENIX .............................................. 161

6. The Monster and the Impossible Genealogy of the Phoenix .............................. 171

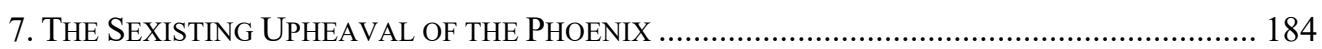

FOURTH CHAPTER. ;MUERE, AMÉRICA ATREVIDA! UNTRANSLATABLES AND

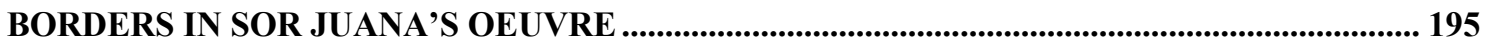

1. INTRODUCTION: THE IMPOSSIBLE ORIGIN OF SOR JUANA …........................................... 195

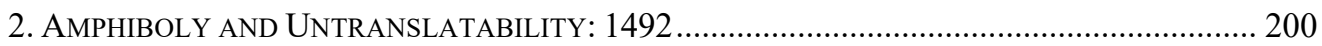

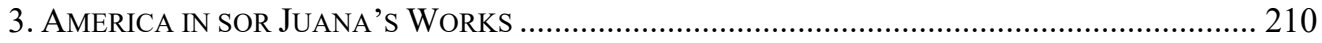

4. LoA al Divino Narciso: A Dialogue Between Conquerors AND AMERiCA................ 222

5. Loa Of the Auto Dedicated to SAn Hermenegildo: The Conquest of America in sor JUANA'S WORK 232

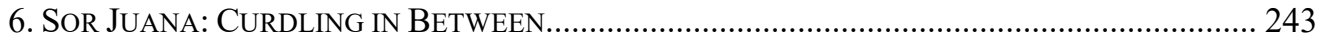

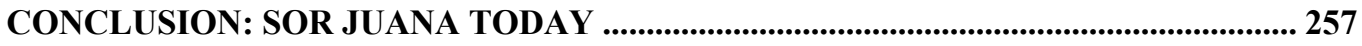

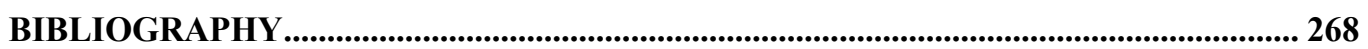

SHORT BIOGRAPHY .................................................................................................................. 287 


\section{English Summary}

\section{Pues no soy mujer. The Upheaval of Singularity in Sor Juana Inés de la Cruz.}

In titling this dissertation Pues no soy mujer: The Upheaval of Singularity in Sor Juana Inés de la Cruz, I decided to center my thesis on the revolution that sor Juana (San Miguel Nepantla 1648?- Mexico City 1695) started in the debate about singularity, sexedness, and in-betweenness - not only in the field of literary studies and literary criticism, but also in the broad landscape of feminist and gender studies. By defining herself neither as a woman, nor as a stable subject belonging to a fixed homogeneous group or genre, sor Juana opens an interesting debate about difference and non-binarism.

As the several examples I analyze in this dissertation suggest, sor Juana problematizes the age-old question of identity from within. This causes not only a disintegration of the structure of identity and of the process of identification, but also a breakup of the very structuralist ground upon which they stand. Presenting a subject that is semiotic, unplaceable, and untranslatable, and that functions along with a sex that is, in its turn, singular, excessive, and also untranslatable, entails a profound reshaping of identity politics beyond the sphere of the metaphysic of presence. In my understanding, sor Juana interestingly configures a non-binary and fluid position for her subjectivity that even today can enter into a powerful dialogue with contemporary feminist theory.

To put in evidence the dynamism of this subject I insisted in the first chapter on the fluidity of the subject; in the second chapter on the resistance that this subject operates against its sexual categorization as a woman; in the third chapter on the proximity between life and death and the continuous movement from a status to the other embodied by the allegory of the Phoenix; and in the fourth chapter on the "in betweenness" and the restlessness of sor Juana's corpus that is impossible to be placed into a single canon once and for all.

In sor Juana's corpus identities are endless and impossible to grasp in their ultimate meaning. They remain forever impossible to place, neither fully present nor fully absent. They exist in a dangerous balance between (nepantla) life and death, dancing and moving, following the chaotic geometry of points, folding the ordinate symmetry of lines, and subverting the hegemonic order of the patriarchal and colonial world. 


\section{Nederlandse samenvatting}

\section{Pues no soy mujer. De omwenteling van singulariteit in Sor Juana Inés de la Cruz.}

In mijn dissertatie getiteld Pues no soy mujer: The Upheaval of Singularity in Sor Juana Inés de la Cruz ontrafel ik de revolutie die sor Juana (San Miguel Nepantla 1648?-Mexico Stad 1695) teweegbracht in het debat over singulariteit, sekse en in-betweenness. Zoals ik uiteenzet anticiperen haar zeventiende eeuwse inzichten niet alleen op hedendaagse theorievorming op het gebied van de literatuurwetenschap en de literaire kritiek, maar ook met betrekking tot het bredere landschap van het feminisme en genderstudies. Door zichzelf noch als vrouw te definiëren, noch als een stabiel subject dat tot een vaste homogene groep of genre behoort, opent sor Juana een interessant debat over sekseverschillen en non-binariteit.

Zoals de verschillende voorbeelden die ik in deze dissertatie analyseer suggereren, problematiseert sor Juana het eeuwenoude vraagstuk van de identiteit. Haar gedachtengang leidt niet alleen tot de desintegratie van de begrippen identiteit en het proces van identificatie, maar ook tot de deconstructie van hun structuralistische grondslag. Deze conceptualisering van het subject, dat tegelijkertijd semiotisch, niet te plaatsen en bovendien onvertaalbaar is, en met een sekse die op haar beurt uniek, excentriek en eveneens onvertaalbaar is, brengt een diepgaande hervorming van hedendaagse identiteitspolitiek met zich mee die verder reikt dan de metafysica van aanwezigheid. Sor Juana neemt hiermee een non-binaire en fluïde positie in ten opzichte van haar subjectiviteit, die zelfs vandaag nog in staat is een krachtige dialoog aan te gaan met de hedendaagse feministische theorie.

Om de dynamiek van dit onderwerp in kaart te brengen, heb ik in het eerste hoofdstuk de nadruk gelegd op de fluïditeit van sor Juana's conceptualisatie van het subject; in het tweede hoofdstuk richt ik mij op het verzet dat dit subject voert tegen een seksuele categorisering als vrouw; in het derde hoofdstuk op de nabijheid tussen het leven en de dood, en de voortdurende beweging van de ene status naar de andere, zoals belichaamd door de allegorie van de Feniks; en in het vierde hoofdstuk op de inbetweenness en rusteloosheid van sor Juana's oeuvre, een oeuvre dat onmogelijk voor eens en voor altijd in één enkele canon kan worden ondergebracht. 
In sor Juana's oeuvre zijn identiteiten onderhevig aan een eindeloze transformatie en onmogelijk te vatten in één enkele, eindige betekenis. Ze blijven voor altijd onmogelijk te fixeren en zijn noch volledig aanwezig, noch volledig afwezig. Ze bestaan in een precair evenwicht tussen (nepantla) het leven en de dood, dansen en bewegen, en volgen de chaotische geometrie van punten, vouwen en de symmetrie van lijnen, en ondermijnen aldus de hegemoniale orde van de patriarchale en koloniale wereld. 


\section{Resumen en español}

Con un título como Pues no soy mujer: The Upheaval of Singularity in Sor Juana Inés de la Cruz, esta tesis quiere concentrar su atención en la revolución que sor Juana Inés de la Cruz (San Miguel Nepantla 1648? - Ciudad de México 1695) causa en el debate sobre la singularidad, el ser sexuados, y el posicionarse entre. Dicho debate no involucra solo los estudios y la crítica literarios, sino también el más amplio panorama de los estudios feministas y de género. Al no definirse nunca unívocamente como mujer, ni como sujeto perteneciente a un grupo o género homogéneo, sor Juana abre un interesante cuestionamiento a propósito de la diferencia y del no-binarismo.

Tal como evidencian los ejemplos citados y analizados en esta tesis, sor Juana problematiza la cuestión de la identidad desde su interior, provocando no sólo una desintegración de la estructura de la identidad y del proceso de identificación, sino una desintegración del terreno estructuralista mismo sobre el cual se fundan. Presentar un sujeto semiótico, imposible de posicionar, intraducible y que funciona junto a un sexo que es, a su vez, singular, excesivo y siempre intraducible, implica una profunda reconfiguración de la identidad política más allá de la esfera de la presencia metafísica. La lectura que presenta este trabajo de los textos de sor Juana destaca que su autora configura - en una manera aguda y fascinante - una posición no binaria y fluida para su subjetividad. Dicha configuración puede dialogar aún hoy con la teoría feminista contemporánea.

Para poner de relieve el dinamismo de la subjetividad en sor Juana, en el primer capítulo se subraya su fluidez; en el segundo, la resistencia que dicha subjetividad opone en contra de su categorización sexual como mujer; en el tercer capítulo, se subraya la cercanía entre vida y muerte y el continuo movimiento entre los dos estados de la existencia representados por la alegoría del Fénix; y en el cuarto, se analiza como es que la inquietud del corpus de sor Juana lo transforma en imposible de posicionar en un canon literario de una manera clara y unívoca. En los escritos de sor Juana los sujetos son infinitos e imposibles de asir en su sentido último. Son sujetos a los que resulta imposible posicionar, sujetos ausentes, o nunca del todo presentes. Sujetos que existen en un peligroso equilibrio entre (nepantla) vida y muerte, danzando y moviéndose, siguiendo la caótica geometría de los puntos, doblando la ordenada simetría de las líneas y subvirtiendo el orden hegemónico del mundo patriarcal y colonial. 


\section{Acknowledgments}

I would like to thank my supervisors for guiding and supporting me during these four years: (in alphabetical order) Prof. Edoardo Balletta, Prof. Rosemarie Buikema, Prof. Gilberta Golinelli, Prof. María José Rodrigo Mora, and Prof. Kathrin Thiele. My research received a special and fundamental impetus from your experience and immense knowledge. I would also like to thank Prof. Giovanni G. Marchetti and Prof. Héctor Rodríguez De La O for believing in my research since my MA and for keeping alive my passion for sor Juana's universe and Mexican literatures from a feminist perspective.

I would like to thank all the extraordinary institutions and people that made possible the realization of this first cotutelle between Utrecht University and the University of Bologna: The Graduate Gender Programme of the Utrecht University; the Netherlands Research School of Gender Studies NOG; the Institute for Cultural Inquiry (ICON) of Utrecht University; the professors of the $\mathrm{PhD}$ board in Modern Languages, Literatures and Cultures (LILEC) of the University of Bologna coordinated by Prof. Gabriella E. Imposti; the professors of the curriculum EDGES PhD in Women's and Gender Studies coordinated by Prof. Serena Baiesi; Drs. Trude Oorschot and Drs. Angela Maritato.

I want to express my gratitude to Prof. Rita Monticelli, who coordinates the GEMMA program - Erasmus Mundus Master's Degree in Women's and Gender Studies for being an indispensable source of inspiration in the field of Gender Studies and who generously helped and motivated me during my research.

I cannot conclude these acknowledgments without mentioning Prof. Lilla Maria Crisafulli who coordinated the EDGES curriculum and the GEMMA program during the first years of my career in Bologna.

I want to thank the whole group of the "Festival delle donne e dei saperi di genere" of the University of Bari, organized by Prof. Francesca Romana Recchia Luciani. This experience changed my life, for the first time opening me to the universe of feminist research.

I want to thank also my friends Begimai, Giulia, Joana, Luca, Valentina, and Wilmarie for being the best people to share this intense experience with.

I am deeply grateful to my family: my sister Annamaria, with whom I experienced the most important moments of our lives; my partner Iulia, who indefatigably followed all the steps of the creation of this dissertation; my mother Mattia Maria; my father Dario Pio; and my grandmother Rosetta. You are the bravest and strongest people I know. 
In Bologna, I had a special family too- people to whom I must say thank you for being there when I was completely alone and for welcoming me in this beautiful city: Barbara, Davide, Enea, Gabriella, Michelangelo, Silvana, and Vito from via del Pratello; Gughi, Michelangelo, and Vincenzo from via Cartoleria.

In Utrecht, I had also a very special family who hosted me and treated me as a family member: Thank you Rianne, Dunya, and Harun for being such amazing and friendly people! 


\section{Introduction. Sor Juana: Seduction, Polysemy, and Revolution}

La seducción de Sor Juana es el triunfo de la diferencia y su gozo.

C. B. López-Portillo Romano and S. Lorenzano Aproximaciones a Sor Juana $(2005$, p. 7)

In titling my dissertation Pues no soy mujer: The Upheaval of Singularity in Sor Juana Inés de la Cruz, I decided to center my thesis on the revolution that sor Juana (San Miguel Nepantla 1648?- Mexico City 1695) started in the debate about the concepts of singularity, sexedness, and in-betweenness - not only in the field of literary studies and literary criticism, but also in the broad landscape of feminist and gender studies. By defining herself neither as a woman, nor as a stable subject belonging to a fixed homogeneous group or genre, sor Juana opens an interesting debate about the concepts and phenomena that we now coin as difference or non-binarism.

From its very beginnings, my research has sought to engage with the question of why it is so important to keep giving full attention to sor Juana's work today. I think that a possible answer to this question resides within sor Juana's own words and in the unchanging power of seduction that they wield over the reader. Their power is not generically predicated on some simplistic emotional or aesthetic approach to the act of reading, but rather has important and wide ranging repercussions, not least for gender and feminist studies, representing an unavoidable and fascinating theoretical contribution to sexedness and subjectivity. Sor Juana seduces, and this act of seduction manifests as the triumph of difference, as stated by Carmen López-Portillo Romano and Sandra Lorenzano in the epigraph to this introduction. I found inspiration in this quote-as I did with the entire Aproximaciones a sor Juana (Approximations to sor Juana; López-Portillo Romano and Lorenzano, 2005) - because it offers the leitmotiv of my approach to sor 
Juana's work; an approach that I condense into the word "seduction". The word embodies, not only the act of being attracted to, but also etymologically, both the acts of being separated from, and the act of being drawn aside (New Oxford American Dictionary, 2010). Therefore, to be seduced means, in a figurative sense, to be attracted by something or someone that separates us from our certainties, and to be drawn aside to have an intimate dialogue - in this case, with sor Juana's words. So, what happens when we are drawn aside by sor Juana to have this (intimate) close reading? Alone with her fascinating words, writing this dissertation, it seemed to me that the enigmas presented by sor Juana are not intended to be solved, but rather to be heard and treated as open questions.

Focusing more closely on these enigmas, to spotlight some, at least the most common, we need to go back to 1926 when the illustrious sorjuanist scholar Dorothy Schons (1926, p. 141) defined these enigmas as "obscure points". These obscure points give rise to the following questions: Why did she enter the cloister? Was she a lesbian? Why did she leave the court where she lived as a protégée of the vicereine Leonor de Carreto? Better still, the questions are also summarized in the verse (below) of the poem by Luis Felipe Fabre, translated by John D. Pluecker, "Sor Juana and Other Monsters" (Fabre \& Pluecker, 2015, p. 1):

The reasons sor Juana took the veil.

The reasons sor Juana wrote the Carta Atenagórica.

The reason sor Juana finally recanted.

Or also, for example:

The real last name of sor Juana.

The real meaning of "Primero Sueño".

The real nature of her relationship with the Marquesa de Paredes alias Lysi. 
These are all legitimate questions, which emanate from a profound silence in sor Juana's biography. However, my research question, while also emerging from sor Juana's texts, is not an inquiry into biographical facts or the many anecdotal accounts of sor Juana's life. Rather, my research question can be summarized as follows: What original contribution does sor Juana's oeuvre make to the contemporary debate about sexedness and subjectivity, in particular a subjectivity that refuses binarism and belonging to a canon understood as a process of colonization?

It is well-known that in the history of philosophy, the term "subject" carries with it two main implications. According to the Italian philosopher Nicola Abbagnano (1994), the word "subject" indicates in its first and ancient meaning, the matter whose it is possible to indicate qualities or predicates. In its second, later meaning, it indicates the "I" that is the spirit or the consciousness, understood as the determining principle of knowledge or action (Abbagnano, 1994, p. 474). In this second meaning of the term, there is a conflation of the subject and the "I". Sor Juana writes precisely at the beginning of the early modern era, before the moment when the subject and the "I" according to western philosophy became reduced to a single definition. However, in sor Juana's writings, it is possible to individuate a subject that is near to becoming the sentient and self-sufficient metaphysical subject, yet still refuses to adhere completely to an idea of subject that self-defines its own "being" (I am referring in particular to the Cartesian cogito ergo "sum"). This resisting subject that so resolutely refuses to be identified with a universal category, and that therefore resists "being", is the nexus between the poststructuralist theoretical perspective from which I read sor Juana's work and the innovation I recognize in her writings. 
After introducing my research question, I now introduce the method adopted to read, and engage in a dialogue with, sor Juana's texts. The unique contribution of this dissertation resides in its attempt to place into a direct dialogue the most recent publications by Jean-Luc Nancy and Jacques Derrida (among other theoretical perspectives, such as also the Deleuzian analysis of baroque; the decolonial theory elaborated by María Lugones; the critique of humanism and 1492 proposed by Sylvia Wynter; and the theory of untranslatability elaborated by Emily Apter) and some of the most intriguing texts by sor Juana, namely El Neptuno Alegórico; Primero Sueño; the poem Respondiendo a un caballero del Perú, que le envió unos barros diciéndola que se volviese hombre $;^{1}$ Romance que respondió nuestra poetisa; ${ }^{2}$ the loa that introduces the auto El Divino Narciso; and the loa that introduces the auto El Mártir del Sacramento, San Hermenegildo. This dialogue is anchored to a post-structuralist approach that affects both the methodology adopted, and the meaning of the term "subject". The poststructuralist perspective represents an attempt to think the subject out of the sphere of being - that is, to think a subject whose first act is not grounded in the affirmation "I am". For this reason, I purposely focus on authors that can accompany the reading of sor Juana's texts: Gilles Deleuze, Jean-Luc Nancy, Jacques Derrida, Emily Apter, María Lugones, and Sylvia Wynter, because they all contributed to the conceptualization of a decentered and fluid subjectivity. Anchored in Deconstruction this dissertation offers the possibility to individuate in sor Juana a contribution to contemporary feminist theory, mainly to the debate on sexedness, subjectivity, and in betweenness. In sor Juana's writings, it is possible to discern an interesting use of the "I" and of the concept of sex

\footnotetext{
${ }^{1}$ The poem's first line is: "Señor: para responderos" (Cruz, 2018, p. 117).

2 The poem's first line is: “'Válgate Apolo por hombre!” (Cruz, 2018, p. 130).
} 
that is able to ascribe each a different meaning and, in doing so, to explore an alternative political functioning for both.

The importance of post-structuralism to my research is not only theoretical; it also offers a valuable methodological lens through which to read sor Juana's work. This methodology is inspired by the four essays about Geschlecht by Jacques Derrida. ${ }^{3}$ In the four works, Derrida underlines the polysemy of the word Geschlecht and the impossibility of reducing it, for example through an operation of translation, to a single definition or meaning. Geschlecht is a noun that derives from the critique to the Heideggerian attribution of sexlessness (Geschlechtlosigkeit) to Dasein (Derrida, 2008, p. 12). In the second essay, Geschlecht becomes, not only the indication of sexual difference, but also the indication of belonging to a species or a genus (Derrida, 2008, p. 33). According to Derrida (2008, p. 7), it is impossible to reduce the word Geschlecht to only one of its possible meanings:

I will leave this word in its own language for reasons that should impose themselves on us in the course of the reading. And it certainly is a matter of "Geschlecht" (the word for sex, race, family, generation, lineage, species, genre), and not of Geschlecht as such: one will not so easily clear away the mark of the word ("Geschlecht") that blocks our access to the thing itself (the Geschlecht); in that word, Heidegger will much later remark the imprint of a blow or a stroke (Schlag). (Derrida, 2008, p. 7)

\footnotetext{
${ }^{3}$ The four essays by Jacques Derrida about Geschlecht are: "Geschlecht: différence sexuelle, différence ontologique", published in Les Cahiers de l'Herne Martin Heidegger, Michel Haar ed., 1983, Paris, L'Herne; "Geschlecht II: La Main d'Heidegger", published in Jacques Derrida, Psyché: Invenstions de l'autre, 1987, Paris, Galilée; Geschlecht III: Sexe, Race, Nation, Humanité, 2018, Paris, Éditions du Seuil; Geschlecht IV is an essay titled "L'Oreille de Heidegger (Philopolémologie Geschlecht IV)" and published in Jacques Derrida, Politiques de l'amitié, 1994, Galilée, Paris. The English translations that I use in this dissertation are: "Geschlecht I: Sexual Difference, Ontological Difference" in Jacques Derrida, Psyche: Inventions of the Other, Volume II, 2008, Stanford University Press, Stanford; "Heidegger's Hand (Geschlecht II)" in Jacques Derrida, Psyche: Inventions of the Other, Volume II, 2008, Stanford University Press, Stanford; Geschlecht III: Sexe, Race, Nation, Humanity, 2020, the University of Chicago Press, Chicago; and "Heidegger's ears: Philopolemology" In Reading Heidegger. Commemorations, John Sallis ed., 1993, Indiana University Press, Bloomington Indianapolis.
} 
From this quote, two main points emerge: First, the term Geschlecht manifests a clear untranslatability; and second, this untranslatability is directly related to the polysemic sense of the term. The inherent impossibility of picking a single meaning at any given time renders translation impossible because such a move would force the translator to choose each time one meaning among many alternatives. This fundamentally characterizes Geschlecht because the use of the term always implicates more than one of its possible meanings. Geschlecht is untranslatable, not only from one language to another, but also within German. Geschlecht is a term that is unreplaceable by other terms with a similar range of meanings. Facing this intersection of untranslatability and polysemy, Geschlecht becomes more than a term: It becomes a metaphor, indeed, even more than a metaphor, a bodily, corporeal manifestation. As such it forms a crack in the principle of non-contradiction - the principle that forces one to make a choice, and only one possible choice, within a binary alternative.

This gamut of meanings, "stock, race, family, species, genus, generation, sex" (Derrida, 2008, p. 51), undergoes another transformation from a word to a mark (Derrida, 2008, p. 51). This mark, which “[p]erhaps it is no longer a word” (Derrida, 2008, p. 51), can be accessed, according to Derrida, only via its de-composition or generation and in this way, one may affirms that it is possible to look at the mark Geschlecht only using its genealogical composition - that is to say, its Geschlecht. "We are going then to concern ourselves", writes Derrida (2008, p. 51), "with the Geschlecht of Geschlecht". Geschlecht is, then, a lens through which we can look and deconstruct something that nonetheless maintains its untranslatability for being polysemic. 
For Derrida, Geschlecht becomes a "lens" useful also as a practical method of reading texts that focuses on the act of listening for the sound of signifiers and their polysemy, rather than on the research of a coherent and unitary meaning of the signified. In particular, it is in the third essay, Geschlecht III: Sex, Race, Nation, Humanity, that Derrida (2020) transforms Geschlecht into an actual method of reading. Importantly, this method works neither as a methodology, nor as a method that reduces the reading of a poem to a paraphrasis that flattens the meaning and "translates" an expression from a more complex to a less complex one, inhibiting the difference and plurality of the text. I decided to adopt the methodological lens of Geschlecht in this thesis because it offers the possibility to read a poem underlining all its possible meanings, without elevating one meaning among many possible different interpretations. In this sense, this method can be considered as inherently "anti-philological" because it does not seek the "origin" of terms, but rather attempts to reveal their current and contemporaneous meaning. Of course, this is not a critique of philological methods tout-court, but rather of the "so-called" philologists (Derrida, 2020, p. 61) that criticize any method that, working on words and texts, accepts different directions and purposes instead of finding the ultimate truth within the text.

The Geschlecht method functions without following a pre-established logic or imposing a meaning upon the text, but rather by following an attraction between the text and the reader. In Geschlecht III, Derrida (2020, pp. 60-61) uses the French verbs magnétiser [magnetize] and aimanter [draw] to distill the ultimate functioning of the method: The reading is not guided (magnetized) by "the internal organization or the apparent meaning of the text" (Derrida, 2020, p. 61), but only by "[...] the text" that attracts or seduces us (as suggested at the beginning of this introduction). Renouncing 
any urge to follow the structure of the text, instead hinging on the moments in which that structure reveals its cracks, the Geschlecht method is perceived by those who are soidisant [so-called] "philosophers, philologists" and "poetic critics" as an arbitrary attitude or as an "anti-philological" (Derrida, 2020, p. 61) reaction to the origin of words and terms. Yet, this method is, in fact, far from arbitrary because it interprets via a process of magnetization or seduction that discerns two singular poles, generating an inherently nonrandomly chosen attraction.

The different perspective that the essays about Geschlecht enable, towards both writing and texts, escapes the classic metaphor of knowledge as a space available only to men and to which it is possible to enter only when accepting the possession of a phallus. The refusal of this possession undermines the common idea of sexual difference because it constitutes a refusal of the phallologocentrism. ${ }^{4}$ The revolutionary position sor Juana assumes with regard to sex will be revealed in my dissertation. To this end, I adopt Geschlecht as a method able to promote a new arrangement of sexual difference. However, this "new arrangement" does not claim to be novel in the sense that it has never been seen before, but rather to displace pre-existing elements into a different order.

In Geschlecht III, Derrida (2020) focuses on the reasons why Heidegger specifically chose the poems of Georg Trakl to conduct his analysis. ${ }^{5}$ The reason Derrida uncovers is interesting in the context of my dissertation because it is linked to the

\footnotetext{
${ }^{4}$ Starting from 1967 with the publication of Of Grammatology, Derrida proposes a neologism that is phallogocentrism to indicate the privilege of the phallus in the construction of meaning in western thought. This same neologism has been adopted by feminist scholars and authors such as Hélène Cixous and Catherine Clément in The Newly Born Woman (1986).

${ }^{5}$ The fourth essay about the term Geschlecht, titled "L'Oreille de Heidegger", was published at the end of Politiques de l'Amitié. Geschlecht $I V$ is a practical demonstration of the theoretical approach to some of Heidegger's texts. The close readings I propose in this thesis are in fact a practical demonstration of how sor Juana's poems hide several elements that become visible only if they undergo a reading that subverts any classical and expected method or methodology. For this reason, I focus mainly on Geschlecht I, Geschlecht II, and Geschlecht III, because they offer a more theoretical insight into the method.
} 
singularity expressed by both the poem and the poetic language in their unique and unrepeatable words. This singularity is often made vulnerable by the anxiety to translate its meaning (be it a paraphrasis, or a literal translation from one language into another), and by the obsession with a philological coherency that does not allow any other link than that of a cause-effect logic to each passage of the analysis. In this sense, "Geschlecht" provides that methodological lens that I use to deconstruct and reveal the many different and concurrent meanings of the verses, words, and expressions used by sor Juana. The texts themselves will show their own ambiguous points - those passages that refuse to be translated into other terms or words that respond to the binary logic of "being" either this or that. In my close readings, I seek to demonstrate a clear will to show how the poetic text is made-borrowing an expression from Catherine Malabou's (2016, p. 38) Changing Difference - of an "unfamiliar, strange, queer" polysemy that needs to be recognized.

The methodological lens Geschlecht allows for an in-depth analysis of the polysemy in sor Juana with two fundamental aims. The first is to overcome a mindset that might otherwise leave sor Juana's work too intrenched in baroque theoretical thinking to be received by the contemporary reader. The second is the adoption of a method not subjected to a hermeneutical perspective that would only be interested in finding the ultimate truth about the text. Therefore, Geschlecht as a lens does not merely highlight the polysemy in sor Juana's texts, but also enters into an active dialogue with this polysemy, hence offering an opening toward other questions that might otherwise remain hidden in some undiscovered and unquestioned fold of the text. Throughout this thesis, Geschlecht operates silently yet effectively, always without assuming the authority of a guiding, undisputable methodology. Throughout the close readings, a sort of "agency" of 
sor Juana's words is demonstrated. This agency is revealed in words' ability to affirm multiple meanings without being subjected to a translation, which would be a reductive strategy — the condensation of a supposed "original text". Indeed, the ultimate reason why I found the lens of Geschlecht so important to reading sor Juana's texts is that it allows me to enhance the specific complexity of her work without losing their quality of being pleasing for being caught in the net of an ultimate interpretation.

What emerges from my close readings is that there is no possibility of translating sor Juana's work into a new text that acknowledges the existence of an original source (the original text). The texts by sor Juana will simply deny any connection to this "original text". Indeed, to underline this aspect, in my dissertation I decided to analyze those works by sor Juana that refer back to "other" (original) texts, either because of the presence of several citations (El Neptuno Alegórico); because the text concerned is a reply to another original text (such as in the case of the poems Respondiendo a un Caballero del Perú and Romance que respondió nuesta poetisa); or because it was a commissioned work (the loa to El Divino Narciso).

Sor Juana's work is thus characterized by several different levels of interpretation. Here, it should be noted that when performing a close reading, I do not pretend to offer the totality of these levels in my analysis. Actually, I do not even want to fulfill the whole spectrum of possibilities that might offer up the baroque text in its infinite folds. To the contrary, what I aim to show is how it is precisely this infinite number of folds that gives the text a life and, as with the metaphor of the Phoenix analyzed in chapter three, these infinite folds represent its endless "reincarnation". Each time the Phoenix - the text"reincarnates" itself, it says something different, and each time a new level of interpretation is revealed. This congruence between Phoenix and text exemplifies the 
importance of a Derridean deconstructive insight. Such a perspective is crucial if one is to fully comprehend the meaning and function of the writing so particular to sor Juana's style.

Derrida's essays about Geschlecht are useful, both theoretically and methodologically: On the one hand, they function as illuminating contributions via which to enter the baroque language, providing a point of entry into the intricate construction of meaning surrounding the semantic field of sex/genre. On the other hand, the approach used by Derrida transforms the word Geschlecht into a sort of unspeakable manifesto of the unexplored potentialities of an underived and pre-differentiated sex. ${ }^{6}$

The benefit of the introduction into the theoretical framework of the first essay “Geschlecht I: Sexual Difference, Ontological Difference" can be found precisely in those passages in which Derrida (2008, p. 26) overcomes binary logic, introducing what he calls "the other sexual difference":

This order of implications opens thinking to a sexual difference that would not yet be sexual duality, difference as dual. As we have already observed, what the lectures neutralized was less sexuality itself than the "generic" mark of sexual difference, belonging to one of the two sexes. [...] The retreat of the dyad leads to the other sexual difference. It may also prepare us for other questions. For instance, this one: How did difference get deposited in the two? Or again, if one insisted on consigning difference within dual opposition, how does multiplication get arrested in difference? And in sexual difference? (Derrida, 2008, p. 26)

\footnotetext{
${ }^{6}$ According to Derrida, sexual neutrality is not automatically a deprivation of sex, but an example of the infinite potentiality of the differentiation of sex. What Derrida (2008) claims in "Geschlecht I: Sexual Difference, Ontological Difference" is that there is not a universal and original source of sexuality that only in a secondary moment is divided into two sexes. Rather, the pre-differential state is not homogeneous and already differentiated (Derrida, 2008, pp. 14-26).
} 
As I attempt to demonstrate in my dissertation, it is possible to recognize that sor Juana's words and the Derridean reconfiguration of sexual difference-a reconfiguration that overcomes the limits of duality and binarism — are both indissociable and mutually supportive, and advance an interpretation of sor Juana's texts that enters into sor Juana's words and comes from within. In this sense, Geschlecht becomes the proper name of a practice that traverses a terrain uninterrupted by binary discourse. ${ }^{7}$

Adopting Geschlecht not only as a method, but also as an (open) theoretical framework and lens, is then a strategy aimed at undermining the idea that a method has to be automatically a methodology. That is to say, that a methodology has to have an inner coherency with a given logic, while in the case of poetry, and in the specific case of baroque poetry, the method of reading and the outcome of the interpretation are already provided by the text that in its own words determines the "correct" manner in which to read. I will start now to describe in detail how this method operates in relation to sor Juana's texts, as well as the questions that emerged from my approach to sor Juana's texts, providing an overview of each chapter.

The first chapter grounds the central theme of the dissertation. It asks, who is the subject that speaks in sor Juana's texts? This question makes it possible to demonstrate

\footnotetext{
${ }^{7}$ In all four essays on Geschlecht, Derrida transforms the Heideggerian Dasein into the possibility to have a body that might have a sex, a gender, and that cannot be included into any pre-existing alternatives. This possibility is not reduceable to a dualistic "to be male" or "to be female", nor to any sexual manifestation that we can imagine within or outside the dualistic paradigm of Being. In this way, the meaning of the verb "to be" changes and, in the moment in which something is impossible to be demonstrated in its universal validity, there is something that can be monstrated. This word pun does not work properly in English because the verb "to demonstrate" has no equivalent that can use the $d e$ - at the beginning as a prefix and as a consequence, nor does there exist a verb that means "to show" and that alliterates with the word "monster", as is the case in Italian [mostrare], French [montrer], and Spanish [mostrar]. Paradoxically, this impossible translation is helpful to better understand what happens in Geschlecht II and in which Jacques Derrida (2008, p. 28) writes at the very beginning: "We are also going to speak of monstrosity." The idea of monstrosity is the bridge that connects the idea of queer that Malabou (2016, p. 38) associates with the "unfamiliar" and the "strange" on the one hand, to the majestic image of the monster that appears in the poem Romance que respondió nuestra poetisa by sor Juana, on the other.
} 
that sor Juana is a feminist ante litteram because of her ability to present a subject that is neither autonomous nor universal, but rather finds its constitution in the voice of the Other. To evidence this singular presentation of the subject and of its authority in the text, the first chapter proposes a reading of those passages from El Neptuno Alegórico and Primero Sueño that so patently exhibit one of the primary aspects of sor Juana's style, namely: the revolutionary use of the strategy of modesty.

Specifically in the case of El Neptuno Alegórico (a complex text comprised of prose and poetry that describes the triumphal arch built following a project by sor Juana in 1680 to honor the entrance of the viceroys in Mexico City) each meaning is "covered" by an enigmatic image (a hieroglyph) that sor Juana reveals and explains in the text. For this reason, the text and the arch (the physical building) are not independent from each other. This continuous act of addressing a physical reality (via the reiteration in the text of the demonstrative "this"), the arch—which is defined by sor Juana as "a labyrinth of drawings" ("Dédalo de dibujos"; Cruz, 1957, p. 403)—creates the effect of addressing an enigmatic reality made of emblems (or hieroglyphs) that escapes a sudden and direct interpretation. In this sense, the subject is in perpetual deferral, because each time it is addressed, it readdresses to another element, avoiding declaring a monolithic meaning. Rather, adopting the lens of Geschlecht, it is easier to demonstrate that this act of deferral contains a subject that is polysemic: the subject understood as the topic of the discourse, and the grammatical subject that speaks in sor Juana's text.

In the act of deferral, however, the subject is not absent. Rather-hidden among quotes, metaphors, and strategies of misdirecting - it is never in the place in which it is sought. In my reading of El Neptuno Alegórico, I decided to pair this text with an essay by Gilles Deleuze: The Fold (1992), an essay specifically dedicated to the peculiarities of 
the baroque subject and its folds. As will become clear in the reading proposed in the first chapter, and as anticipated some lines above, the subject in sor Juana's texts will often encounter the metaphor of the labyrinth. This crucial metaphor will be the main bridge between Deleuze's text and sor Juana's.

Through the lens of a Deleuzian interpretation of the baroque and its folds, sor Juana's words are able to fully reveal their cryptic connections and fluidity. The act of deciphering the text El Neptuno Alegórico shows how the idea of the subject in sor Juana resonates perfectly with the poststructuralist idea of the subject which, in turn, can be distilled into Derrida's argument in his essay about the Khôra (1995): a subject that is always on the brink of being named and existing, but that for one reason or another cannot be, thus escaping the possibility to be caught and depicted. The fluid metaphors deployed by sor Juana that stand for the subject (i.e., the labyrinth, water, the fluid female voice) are in contrast with the solid idea of the modern subject proposed by Descartes $(1988, \mathrm{p}$. 603) when he affirms its famous "je pense, donc je suis" (or, in Latin, cogito, ergo sum).

The subject that permeates the words of sor Juana, far from being easily individuated, demonstrates an unexpected relationship with sex. For this reason, in the first chapter I also propose a reading of the poem Primero Sueño, and of the appearance of the pronoun "I" at the end of the poem that conjugates sor Juana's subject- the same subject that we saw deprived of its matter in El Neptuno Alegórico, with a sex that represents a non-separable fold of the subject itself. In fact, the famous ending line of the poem - "y yo despierta" — can be referred either to the author or to the soul (a feminine noun in Spanish), and shows how the meaning of the feminine adjective changes according to the sense of the "I" $[y o]$. What is at stake in this chapter is the substantiality of the subject, its temporal instantaneity (El Neptuno Alegórico), and its refusal to be 
neutral or abstract. Yet, can we take for granted that the female gender of the adjective despierta refers to the sex of the word "I"? This question enhances the critical emphasis that the word "sex" places on a text from the seventeenth century read today. Indeed, is the pairing of sex and gender the only possible pairing in which the word "sex" functions? Once I have identified the subject that speaks, I move on to answer this question in the second chapter.

The poem analyzed in the second chapter, Respondiendo a un caballero del Perú, is a crucial composition that on the one hand deals with the issue of the subject, and on the other, with the issue of sex. The chapter first establishes that the subject involved in the poem is in fact a semiotic subject that replies to another poem (the poem written by the Peruvian gentleman). More importantly, as the chapter then shows, sex is neither a condition — a sexual gender—nor a fixed and predetermined position. Rather, along with the subject, it is an act that rests in the sphere of existence and not necessarily in the sphere of Being in the metaphysical sense. This is both important and revolutionary because it subverts the static idea of a female or male subject constantly defined by the principle of non-contradiction. Simultaneously, sor Juana's refusal to declare her sex in the poem-claiming instead that her body is neutral, neuter, and abstract — clearly demonstrates that her body and "sex" exist, but that both are, in fact, free acts rather than entrapped states of Being. In other words, they exist beyond the possibility to say what they are or what they are not, and act beyond the range of the ontological paradigm. Therefore, the idea of "sex" in sor Juana is a bodily resistance to any categorization that presupposes the principle of non-contradiction to function.

In this second chapter, this resistance is expressed by the use of the pairing "sex/genre" instead of "sex/gender". Indeed, the Spanish word género simultaneously 
translates the English terms "gender" and "genre". I focus on the pair sex/genre to draw attention to the idea that sex no longer functions in opposition to "nature/culture". Hence, it is not something that indicates what a subject $i s$, but rather what a subjectivity does according to its free and different singularity. Thanks to a dialogue established with a recent publication by Jean-Luc Nancy (2017), entitled Sexistence, in which Nancy explores the consequences and the reasons of considering "sex" as a free act instead of a predetermined category, it will be even clearer what it is that sor Juana places out of sight and under so many folds in her words. What becomes clear is that when it transcends the sphere of Being, the word "sex" can individuate something that is unspoken, unspeakable, or unreplaceable. Instead of representing the unchangeable "natural" side of the "sex/gender" pairing, "sex/genre" becomes a fluid and liberated act of resistance against any act of being forced into a "homogeneous group" (genre). Inspired by the neologism forged by Nancy, sexistence, by uniting the word sexe and existence, I propose to call this act of resistance sexistance, a word that encompasses and unites Derridean différance, "sex", and "resistance".

Once exposed as the meaning of sex in sor Juana's significant poem Respondiendo a un caballero del Perú, this idea poses new questions that are tackled in the third chapter. The operation of critique of the binary gender system, into which sor Juana refuses to enter, makes a claim for a body that does not want to lean toward one sex or another. This act in its turn, poses the following question: Is the concept of singularity a valid mechanism via which to add something to the singular definition of sex proposed by sor Juana? Such a question points toward the necessity of configuring differently the perception of singularity, not least because, in another poem, sor Juana delves into this 
very theme, connecting the singularity of sex on the one hand, and the singularity intended as being unique and unclassifiable on the other.

The focus of the third chapter is a poem in which sor Juana discusses the central theme of singularity. Romance que respondió nuestra poetisa is dedicated to the intricate metaphor of the Phoenix, a figure that embodies the impossibility to occupy a fixed position and the impossibility to belong to a genre. In her reply, sor Juana emphasizes some particular features of the Phoenix, primarily focusing on its capability to be both alive and dead in the same space and time. She proposes an evolution of the particular idea of the sexed subject presented in the first and second chapters of this dissertation. This evolution of the idea of the sexed subject is characterized as the overcoming of the life/death dichotomy and it is important that this act of overcoming can occur only thanks to the deployment of a metaphor. This is because the metaphor is useful to interpret the singularity expressed by sex, not as a monadic element, but as an element in motion, in relation to other elements, and in revolt. Thanks to this act of overcoming, sor Juana displaces the idea of sex from the contraposition female/male. She undermines the very principle of non-contradiction when she presents the Phoenix as a creature that is simultaneously alive and dead. The abolition of the principle of non-contradiction places the subject in motion in a perennial deferral of place in which the Hegelian dialectic is dismantled by the deconstruction of the conflict among differences. Indeed, in the poem Romance que respondió nuestra poetisa, sor Juana affirms that the Phoenix agrees grammatically with the masculine gender, but its referent is not necessarily a masculine being. This scission between the grammatical norm and the sex of the Phoenix is an example of an act of sexistance as discussed in chapter two. 
In Romance que respondió nuestra poetisa, sor Juana's identification with the Phoenix is taken to the extreme when she describes how to be the Phoenix affects her life. This description is a revindication of singularity by sor Juana (now speaking with the voice of the Phoenix, but also clarifying that the Phoenix is a metaphor of writing) that this time has as its target an explicit dissent from the possibility of forming or participating in a homogeneous group. The contribution of sor Juana to the contemporary debate about sex here is a critique of the concept of "genre". What happens to the subject that refuses to be grouped into a genre? Is it destined to die? The metaphor of the Phoenix suggests the contrary: The subject that refuses to be grouped is destined for perennial rebirth.

Is it possible to distinguish a point of departure in sor Juana's revolt of the subject? Is it possible to indicate a "where" in which the upheaval of the subject happens? The answers to these questions provide the core argument of the fourth chapter, which is dedicated to the impossibility of finding a stable and steady position for sor Juana's oeuvre in the literary canon and the feminist canon. The act of placing sor Juana's oeuvre in the canon is subverted, not only by the theoretical insights already gleaned from the preceding chapters, but also because of her "national" identity. In sor Juana's writings, there are several references to the national development of New Spain and Mexico, however, these two different geographical concepts are influenced by the recent conquest of the territories and by the consequent colonial situation. Again, the reading of sor Juana's works from a deconstructive perspective leads me to pay specific attention to these influences and to question the ultimate attempt of positioning sor Juana in a literary canon. 
The question of how sor Juana describes Mexico in her writings is not sufficiently answered by cursory analysis of the passages dedicated to this description by sor Juana. Rather, it will be necessary to examine how sor Juana describes America, the conquest, the year of the "discovery" 1492 (which she distinguishes from the conquest), and also how she describes Europe and the Europeans arriving in the Americas. These descriptions need "translation" because such concepts are not used in the same sense in which they are used today. Nonetheless, they represent an opportunity to proceed toward new issues. For example, the question of translatability will be approached with reference to Against World Literature by Emily Apter (2013), as it provides foundational theoretical insights into the political outcomes of the revindication of untranslatability. Regarding the fateful year itself (1492), I place sor Juana and Sylvia Wynter into a productive dialogue, as a critical reading of the common interpretation of the outcome of the conquest is needed in order to understand some of the more complicated rhetorical strategies adopted by sor Juana.

Another aspect that necessitates further exploration is the position from which sor Juana speaks, specifically, how the colonial system affected the relationship between the author and her perception of national belonging. To analyze these aspects, it will be helpful to adopt a theoretical framework informed by María Lugones's essays regarding colonial gender, decolonial feminism, mestizaje, and the forced homogeneity of colonial society. In order to enable an in-depth analysis of the complex concept of mestiza and the Nahuatl word Nepantla (a concept that intersects the life of sor Juana, who was born in a village called San Miguel Nepantla), I will use the classic and (to this day) inspiring text by Gloria Anzaldúa (1987) Borderlands/La Frontera. Anzaldúa's work unifies the analysis of the "borderlands" created by the act of translating, and the question of the 
nepantilism as a perennial restless movement of the mestiza. I compare this restless movement with the restless movement of the literary production of sor Juana, explicating how sor Juana plays with the problematic American influence in her texts. I explain the theoretical outcome that has to think "Nepantla"- that is to say, "in the middle"expanding upon the open structure of "Nepantla" as the point of departure of the revolt of the subject.

Of course, as for any other identity, also the establishment of a national identity is problematic in sor Juana's work and the attempt will necessarily generate paradoxes. First, she claims to belong to a nation that in fact does not exist as an independent state. Second, the Mexican nation sor Juana presents, is characterized by a multiplicity of forces that make it all but impossible to identify it as a singular entity. In fact, sor Juana does not waste the opportunity to deal with the ideas of America and the conquest, subverting here too any nationalistic claim of belonging to a homogeneous group. Through the reading of both the loa that precedes the auto El Divino Narciso, and the loa that precedes the auto dedicated to San Hermenegildo, it is possible to discover a precise perspective that sor Juana develops about the conquest of America. And indeed from this perspective, it is clear that the experience of conquest is not easily translatable, since it is marked by several concepts, such as America, Mexico, the West, or the very act of discovery, that are not easily reduceable and movable through the checkpoints and borders of translation (Apter, 2013) because they do not correspond to our contemporary idea of them.

So, in conclusion, what precisely is the contribution of sor Juana to the contemporary debate about sex and subjectivity, especially when a colonial condition is taking place? As the several examples I analyze in this dissertation suggest, sor Juana problematizes the age-old question of identity from within. This precipitates, not only a 
disintegration of the structure of identity and of the process of identification, but also a breakup of the very structuralist ground upon which they stand. Presenting a subject that is semiotic, unplaceable, and untranslatable, and that functions along with a sex that is, in its turn, singular, excessive, and also untranslatable, entails a profound reshaping of identity politics beyond the sphere of metaphysical presence. In my understanding, sor Juana interestingly reconfigures a non-binary and fluid position for her complex subjectivity, both as a woman poet and a criollo in colonized Mexico, that even today can enter into a powerful dialogue with contemporary feminist theory.

Sor Juana's Phoenix, the creature that challenges the binarism, is not a monstrous creature, but in the hands of sor Juana rather becomes a creature that embodies the space "in between" (nepantla). For being nepantla, sor Juana's Phoenix is a creature that is not locatable and (between) life and death, moving beyond the simple definition of what is present or absent. As Vicki Kirby (2009, p. 108) writes concerning deconstruction: "Put simply, deconstruction complicates the logic wherein identities are posited as finite, locatable, as simply present or not." This quote I find extremely appropriate in the context of the fundamental questions posed by sor Juana's texts, in which identities are endless and impossible to grasp in their ultimate meaning (Primero Sueño). They remain forever impossible to place, neither fully present nor fully absent. They exist in a dangerous balance between (nepantla) life and death, dancing and moving, following the chaotic geometry of points, folding the ordinate symmetry of lines, and subverting the hegemonic order of the colonial world.

This thesis, in conclusion, wants to offer an example of how complex texts can be read without blighting the possibility of recognizing their in betweenness and their unreplaceable singularity. 


\section{First Chapter. The Sexual Revolution of the Subject: From El Neptuno Alegórico to Primero Sueño}

\section{Introduction: How to Read Sor Juana's Texts Without Separating Sex from}

\section{Subject?}

The first chapter of this thesis aims to explore the connection between the concept of subject and the concept sex in sor Juana's work-most notably, its repercussions for the process of writing texts. As the title suggests, this chapter explores the subject in its various shapes, possibilities, and "revolutionary functioning"-a functioning that depends on the specific relationship that sex and the subject have in sor Juana Inés de la Cruz's literary corpus. Indeed, a peculiar aspect of sor Juana's writing is that sex and subject mutually define each other and are often entangled via different rhetorical strategies. In order to frame this conceptual entanglement in sor Juana's work, it is necessary to find a strategy of reading that makes possible, not only an unpacking of the very concepts of subject and sex, but also to approach them at a close range.

Writing during the second half of the seventeenth century, sor Juana's work is situated at the threshold of that era of modern philosophy in which the problem of the subject becomes central — an era that was inaugurated by René Descartes only a few decades earlier. Sor Juana possibly foresaw the approaching centrality of the subject that came to dominate the modern age, in which the concept of the subject also underwent a process of "solidification". As Michel Foucault states in the first lesson of his 1981-1982 course, L'Herméneutique du sujet, it is possible to discern in the modern age the moment at which the subject becomes the subject of knowledge and separates itself from the object of knowledge (Foucault, 2001, pp. 17-19). 
However, following mainly the Neoplatonic school and Athanasius Kircher (1602-1680; Pascual Buxó, 1996, pp. 181-204), a German Jesuit contemporary of Descartes, sor Juana adopts a distinctly non-Cartesian perspective on both the subject and subjectivity. This divergence in thinking permits me to read her literary production, not according to the classical philosophical sources that celebrate the subject as the most outstanding example of the corporeal body, but rather, according to the philosophical critique that, since the second half of the twentieth century, has fractured and shattered any solid and substantial idea of subject. In particular, I reference Derridean deconstruction not in an attempt to literally 'deconstruct' sor Juana's work, but to underline the deconstructive potential of her oeuvre.

The quest for an appropriate reading strategy necessitated first finding the proper unitary works to consider as a starting point from which to approach the question of sex and subject in sor Juana's work. The most authoritative studies of sor Juana's output (see Arenal, 1991; Cooley, 2005; Glantz, 2006; Merrim, 1991) are based on the philosophical poem Primero Sueño (written around 1685-1691), and focus in particular on the unexpected presence of a feminine adjective for the word "I" in the final verse: "[...] el mundo iluminado y yo despierta" (Cruz, 2018, p. 299, emphasis added). ${ }^{8}$ Subverting this tendency, I propose to take El Neptuno Alegórico (written in approximately 1680) as my point of departure. This work is not usually explicitly connected with the concepts of sex and subject, but nonetheless offers the possibility to explore the question of criollo $^{9}$ subjectivity, as well as other issues that positioned the subject as the political or social identification of an abstract being, or legal entity.

\footnotetext{
${ }^{8}$ Throughout this dissertation, emphasis is original unless indicated otherwise.

${ }^{9}$ Criollo is an adjective used to refer to people who were born in the Americas to Spanish parents.
} 
El Neptuno Alegórico is a complex work by sor Juana. It is complex because of its structure and because of its meaning. The main reason of this complexity is represented by the fact that this text has been composed to describe a physical triumphal arch that today does not exist anymore. As we will see in detail in the next section, the specific triumphal arch that describes sor Juana was made to celebrate the arrival of the viceroys in Mexico City in 1680. By the reading of the work by sor Juana we can imagine how this arch was composed. In fact, each section of the work describes a part of the arch and explains the meaning of each drawing present on the canvases and panels of the arch. The descriptions that sor Juana proposes in her text El Neptuno Alegórico provide the observer of the arch of all the explanation about the subjects of the drawings that were in form of emblems, hieroglyphs, and allegories. What remains today of this arch, as mentioned, is only the text by sor Juana that in her deep and keen knowledge explained not only the meaning of the singular drawing, but also the general meaning of what entails the use emblems and hieroglyphs.

Adopting El Neptuno Alegórico as my starting point afforded me the possibility to define my reading method and its direction in the context of sor Juana's corpus. $E l$ Neptuno Alegórico encourages the adoption of a semiotic perspective via which to interpret the relationship between sex and the subject in sor Juana's work, not least because, as I will show, this work configures the subject more as a sign than as a substance. By starting with El Neptuno Alegórico and working toward Primero Sueño, I adopt a route that guides the reader through three important steps. The first step examines the deconstruction of the subject and its transformation into a sign. The second reflects on the semiotic meaning of considering the subject as a sign. The third and final step 
approaches the final verse of Primero Sueño as representing the pinnacle of the process of entangling sex and subject.

I will attempt to separate sor Juana's notion of the subject from the conflictual space of sex intended as sexual duality (male/female; masculine/feminine), but also, following a broader idea of duality, to move away from any form of dualistic space that forces the subject into a self-definition constrained by the law of non-contradiction. The "sexual revolution of the subject" alluded to in the title to this chapter is, in fact, a revolution against the ideological constraints that emerge from the need to define and delimit the possibilities of movement always (and solely) between two opposite poles. Such an oppositional framing merely acts to exclude the interesting implications of what is impossible or incoherent. Furthermore, the action itself - that of revolution-indicates a movement around a central axis represented, in the first part of the chapter, specifically by the subject.

\section{Which Subject Speaks in Sor Juana's El Neptuno Alegórico?}

The following section offers an initial examination of the entanglement of sex and the subject using El Neptuno Alegórico as our point of departure. However, it is difficult to fully grasp El Neptuno Alegórico without first addressing some of the more enigmatic elements of the text. Here, I should emphasize that the complex structure of El Neptuno Alegórico is precisely the reason I decided to take the text as my point of departure. El Neptuno Alegórico belongs to the long tradition of the so-called "Triumphal Arches"designed, composed, or painted along the line of the Imperial Arches of ancient Rome and re-established mostly between the fourteenth and the sixteenth century. In 1680 , the viceroy Tomás Antonio de la Cerda, third marquess de la Laguna, with his wife, María 
Luisa Manrique de Lara y Gonzaga, countess de Paredes, made their entrance into Mexico City. Octavio Paz (1982, pp. 197-199) offers a detailed analysis of the structure of the ceremony, from the arrival of the viceroys in Veracruz to their entrance into the capital. Paz's (1982, p. 197) analysis highlights the double heritage of the ritual: the triumphs of ancient Imperial Rome, and the ritual of the Medieval entrée. According to Paz, during the Renaissance the two traditions merged in a unique ritual that preserves both styles. This specific type of ritual was observed throughout the entire seventeenth century in the Spanish territories, especially in the viceroyalty of New Spain, where sor Juana lived (Paz, 1982, pp. 198-199).

El Neptuno Alegórico, the text written by sor Juana, is the description and explanation in both prose and verse of the paintings and canvases that constitute the Triumphal Arch. There were, in other words, a Neptuno Alegórico that was the physical Triumphal Arch adorned by canvases and built following the project made by sor Juana (today lost), and a Neptuno Alegórico, text that I will comment in this chapter, that is the text that sor Juana writes to explain and describe the Triumphal Arch.

The text is structured as follows: The opening is a classical dedication of the work to the viceroy. The second part is entitled "Razón de la fábrica alegórica, y aplicación de la fábula", in which sor Juana explains the reasons for the allegorical construction and its invention. While, the third part describes the inscriptions on the arch and is entitled "Inscripción". There then follows a description in prose of each topic of the eight canvases with a short poem ending each section. These descriptions have as their titles: "Argumento del primer lienzo"; "Argumento del Segundo lienzo", etc. (the argument of the first canvas, the argument of the second canvas, etc.). The fourth part provides a description of the bases of the two columns that support the structure of the arch itself. 
There are four sections, two for the right side and two for the left side, titled "Primera basa de mano diestra"; "Segunda basa de mano diestra"; "Primera basa de mano siniestra"; and "Segunda basa de mano siniestra" respectively. Sor Juana then describes the intercolumniation in two new sections: "Primer intercolumnio de mano diestra" and "Segundo intercolumnio". The final section is entitled "Explicación del Arco" and is, according to Alberto Salceda (Cruz, 1957, p. 626), the explanation in verse of the symbolism of the text, which was composed with the purpose of being read in front of the actual architectural arch on the day of the arrival of the viceroys. This final section also appeared as a self-contained edition.

El Neptuno Alegórico belongs to a specific literary genre known as emblematica - a literary form typical of the Renaissance. An emblem book is a collection of epigrams and illustrations accompanied by brief descriptions or explanations. A famous example of this genre is Emblemata by the Italian intellectual Andrea Alciato (1492-1550) published in 1531. Indeed, sor Juana often quotes Alciato's text in El Neptuno, however, there are some important differences between the two works. The most obvious difference is that Alciato's Emblemata contains figures- that is to say, the emblems themselves upon which the author comments are not only textual descriptions and explanations of each emblem—while in sor Juana's text, there are no images.

The first feature that stands out in the El Neptuno Alegórico is the constant and extensive use of direct and indirect quotes. This technique, of building the text through the voice of other authors, raises several questions. First, how might we identify the intellectual background of sor Juana—her own academic context? Second, how can we recognize the "authentic" voice of sor Juana among these other voices? Third, what is the difference between "authentic" and "original"? What I hope to demonstrate is how these 
questions are based on a specific idea of the subject that is assumed to be the source of its own voice - precisely the idea that sor Juana deconstructs. In this section, therefore, I try to shift the emphasis toward an idea of the subject that find its voice outside and beyond itself. To accomplish this, I first need to reformulate both the principles of authenticity and originality. Unless this is done first, it will prove impossible to identify the passage that marks the moment the subject passes from substance to sign in $E l$ Neptuno Alegórico. At this point, I need to address the three questions posed above. I begin with a specific example in sor Juana and then move toward a more general understanding, deconstructing the classical idea of the subject as some pure source of thought that necessarily implies a strong connection between the originality and authenticity of its voice.

Despite the attempt made by Ermilo Abreu Gómez (1934) in his essay Sor Juana Inés de la Cruz: Bibliografia y Biblioteca, it is impossible to know the actual number and titles of books possessed by sor Juana—a situation that also makes it almost impossible to ascertain our author's intellectual background. However, would it really help much to know exactly which books sor Juana was in possession of when it comes to identifying how the subject is formed and presented within her work? Obviously not, as merely owning a book (even at a time when such ownership was in itself notable) tells one nothing about the level of engagement the owner actually enjoyed with the text. Furthermore, even if we were to be in the desirable situation of knowing exactly which texts comprised sor Juana's personal library, it would be at best overconfident and at worst simply naïve to determine sor Juana's intellectual status on the strength of her library. Nonetheless, a minimal awareness of the depth of sor Juana's literary background proves fruitful when one attempts to identify quotes or references within her work. 
In fact, the only solid clue that we have regarding this issue is contained within sor Juana's own words, although it only becomes apparent by paying careful attention to the words themselves. Here, I would like to emphasize, once more, the importance that this investigation attaches to a measured, well-grounded close reading of texts. For this reason, identifying the passages sor Juana references, and the authors, doctrines, or theories she mentions, is crucial. Such passages should not be considered as separate from the supposed "authentic" voice of the author. Rather, their presence reveals an ongoing inner dialogue between sor Juana and her "silent teachers". However, this dialogue should not be understood as a dualistic space comprised of independent questions and their related answers, or one that aims to identify all of the different speakers throughout the text in order to assign an author to each individual passage. In other words, any interest in the presence of citations should aim to recognize and understand the functioning of the intertextual level of sor Juana's texts because, in this way, it is possible for the reader to discern the intricate network of conceptual and rhetorical threads created by the author. The dialogue is thus transformed, revealing the relationship between voices. Indeed, following a semiotic standpoint influenced by Augusto Ponzio's essays about Mikhail Bakhtin, "the dialogic character of the subject" should always be considered as “inevitable" (Ponzio, 1993, p. 44). By positioning this "dialogic character" both without and within the subject, the act of quoting will no longer be understood as an external dialogue between sor Juana and her "silent teachers" (that is to say, the books she read), but as a fundamental and integral part of her "voice". This change of direction, from the dialogue to the dialogical, marks the beginning of a process — of a folding of the sign (Deleuze,1993) that makes it possible to observe its different parts as facets rather than separate elements. This change leads us toward an interesting and specific feature of the 
baroque esthetic and epistemology that will be discussed later in the chapter-the labyrinth.

Turning now to the final question, "authenticity" and "originality" are not only related to the problem of the act of quoting. There is also a need to decrease the moral value that they accumulated during the modern age. Paying homage to authenticity deprives all words of their freedom, since any recognition of "originality" or "authenticity" implies that those words have to be enslaved and possessed by authors"belonging" to him or her, and recognizing them as true only if inalienable. Yet, conversely, not to enter in conflict with the radical freedom of writing, claimed once more by sor Juana in her famous letter La Respuesta a Sor Filotea, and to better perceive and follow a premodern aesthetics, one of the first beliefs that has to be abandoned, is the logic of the "copyright" as we know it in a post-Romantic, post-Idealist, and capitalist context. ${ }^{10}$ Although it is not useful to enter into more depth with this example in this context, it is worth remembering that, in the absence of a law about intellectual property, the meaning of terms such as "citation", "quote", "original", or "authenticity" have to be reformulated and rethought outside of their contemporary legal and moral regulation based on the individual sovereignty of the author. Furthermore, the space of the meaning and the space of the sign are presented by sor Juana as imperfectly aligned. In presenting the explanation of the different emblems that constitute the text, sor Juana uses a specific

\footnotetext{
${ }^{10}$ To give a clear example of this, it is useful to reference another text. The history of the spurious Quijote published in 1614 under the authorship of Alonso Fernández de Avellaneda (cf. Alfonso Martín Jiménez, Cervantes y Pasamonte: la replica cervantina al Quijote de Avellaneda, Madrid, Biblioteca Nueva, 2005) demonstrates how, without any Intellectual Property Law, the author of the first part of El ingenioso hidalgo don Quijote de la Mancha published in 1605, Miguel de Cervantes, managed to regain the authorship of the history of Quijote only by publishing a new volume of the novel specifying in the title that this edition had been written by "Miguel de Cervantes, autor de su primera parte" (or, in English, "Miguel de Cervantes, author of its first part"; Martín Jiménez, 2005, p. 15). In addition to this declaration, Cervantes built a complex series of subtle textual "encounters" between his Quijote and Avellaneda's Quijote.
} 
bibliography that permits her to keep "folding" the sign and, at the same time, to make reference to the absolute otherness that the sign can neither reach nor comprehend.

Thus, the attempt to detect specific sources in a given text is not an attempt to actively contextualize the text, nor to delineate a border between sor Juana's words and those of another author. Rather, I would like to expand any such borders to such an extent that the text can live in a space free from identity or other dangerous processes of (mis)appropriation. If nothing else, any so-called "context" needs to be thought of as shaking its connection with the present in which the author is writing. When sor Juana quotes the work of another author in her text, she extrapolates and recontextualizes the quoted text. Quoting, indeed, means to select, to extract, and to re-insert the quoted text into another discourse and into another context. In Derridean terms (Derrida, 1994), quoting is an operation of re-signification of the text in which the text is recontextualized. According to Derrida, the interpretation of a text is not bound to the comprehension of the context of its production; is not bound to the act of giving back the text to the present in which it was written. On the contrary, the interpretation of a text means to free the text from present and entrust it to the future of its possible interpretations (Derrida, 1994, pp. xvii$\mathrm{xviii)}$. Therefore, there is no context and writing that occupy the same synchronic line, because it is impossible to place synchrony and writing in direct contact.

\section{The Labyrinth and the Baroque Folds of the Sign}

I will introduce the text of El Neptuno Alegórico, focusing on the figure of the labyrinth, as it exemplifies a different pluralization of the sign that shows how, if considering the subject as a sign, it is possible to understand the intersectionality of the subject, not as the mere addition or sum of different elements, but as an indissoluble entanglement thereof. The labyrinth, a classic image of the baroque, is associated first and foremost with the 
Minotaur, a mythological figure that is half human and half beast, and embodies the typical leitmotif of the baroque esthetic - the juxtaposition of two opposing concepts. In sor Juana's work, the labyrinth features in the play Amor es más laberinto (1692). It should, however, be noted that the Minotaur is not the main protagonist of the play. The labyrinth is also the figure chosen by José Pascual Buxó (1996) in his essay dedicated to the enigmatic death and disappearance of sor Juana, entitled "Sor Juana Inés de la Cruz: Monstruo de su laberinto".

The figure of the labyrinth provides a useful way to introduce the subject of cryptography - a crucial concept, analyzed below. Indeed, the construction and affirmation of the subject that inhabits the "I" follows an intricate path. The deciphering of this path is a process that combines two elements: the labyrinth and the impossibility of stating a clear and conclusive destination. Furthermore, the labyrinth is not the most common critical device via which to approach the specific composition of El Neptuno Alegórico. Hidden among other strong metaphors, such as water, the labyrinth appears explicitly in the verses that describe the architecture of El Neptuno Alegórico. Understanding the labyrinthine nature of El Neptuno Alegórico will prove helpful, in addition to the aforementioned cryptographies of the subject, to grasp the roles played by its many other figurations. In other words, I decided to focus on the labyrinth as a central point of departure upon which all other figurations depend, and as the key to gain access to a deeper level of the text.

After a long and detailed explanation in prose of the structure of the arch, there follows an explanation of the arch in verse, Explicación del Arco. The quatrains from line 17 to line 48 are introduced by the anaphora of the demonstrative pronoun "éste" (this), and of the demonstrative adjective "este" (this), both referring to the arch itself. In this 
deixis (este), the grammatical subject makes reference to the arch that is the subject (topic) of the text. This reference is conveyed thanks to the description of the emblems depicted on the arch. The peculiarity of this process is that the deixis is normally a sign that makes directly reference to its object, while in this case, the object is not present anymore and hence, the reference is indirect. This indirect reference is possible thanks to the description of the emblems on the arch in the text. The deixis (este) is a grammatical subject that makes reference to the subject (topic) of the text through its own signs (emblems) and, therefore, this deixis presents the first occurrence of the image of a semiotic subject.

The deixis outlined above is a necessary process because Explicación del Arco follows the constant deferral of the subject (topic) of the text (the arch), which started with the very idea of sor Juana building the arch as an emblema - that is to say, as a representation of an allegorical figure. Sor Juana imagines and plans an architectural structure (the arch as the subject/topic of the prose) that functions as a text. The text of the arch takes the form of emblems, each with a secondary, hidden meaning. The hidden meaning of the emblem indicates something that cannot be reached directly, but requires a new allegory to complete its meaning.

In the following quote, I detail the first and the second quatrains to exemplify how El Neptuno Alegórico - in this case, the triumphal arch — is positioned as the object and "indicated" by the author through the use of the adjective/pronoun "this" (este, éste):

Este, Señor, triunfal arco, que artificioso compuso más el estudio de amor que no el amor del estudio; éste, que en obsequio vuestro 
gloriosamente introdujo

a ser vecino del cielo

el afecto y el discurso;

(Cruz, 1957, p. 403, emphasis added)

The stanzas above refer to the triumphal arch using the deictic "this" (éste, este) that physically indicates the arch. "This" (este) triumphal arch is, according to sor Juana, composed more by the study of love (el estudio de amor) than by the love for study (amor del estudio). These lines are an example of the convoluted style adopted by sor Juana. In declaring a sort of modesty (when she affirms that she did not make a deep study to compose this work), she indeed affirms that she preferred to study the topic of love- a very intricate and complex topic. In the second stanza, the deixis (éste) becomes the subject, reiterating the idea that the composition (the text) and the physical building of the triumphal arch are the same thing, but also that this thing (consisting both of the text and of the physical triumphal arch) is the grammatical subject (which accomplishes the action in the text) as well as the topic (subject) of the text. The substance of the arch and the immateriality of the text merge into a singular position. These two first stanzas are also helpful to understand the labyrinth as the metaphor for a subject that folds itself several times to change its own state from the substantial subject to the substance of a sign.

In the following quatrains, the author affirms that the arch is "a Cicero without tongue", "a silent Demosthenes", with a "voice made of colors", able to make "public the triumphs" of the viceroy:

Este Cicerón sin lengua, este Demóstenes mudo, que con voces de colores 
nos publica vuestros triunfos;

(Cruz, 1957, p. 403)

The structure is defined as an almost arrogant and curious building reaching toward the sky, subtly reminiscent of a voiceless Tower of Babel:
este explorador del aire,
que entre sus arcanos puros
sube a investigar curioso
los imperceptibles rumbos;
este atalaya del cielo,
que, a ser racional, presumo
que al Sol pudiera contarle
los rayos uno por uno;
(Cruz, 1957, p. 403)

In the next verses, El Neptuno Alegórico is described as a "Prometheus made of canvas", and a "Dedalus made of drawings". The first reference is to Titan's Prometheus, who, according to the Greek myth, quoted in the verse "que impune usurpa los rayos" ("that with impunity usurps the rays of the sun"), stole the fire from the chariot of Helios. The second character is Dedalus, the famous architect of the labyrinth of Crete and father of another crucial figure in sor Juana's works, namely, Icarus:

este Prometeo de lienzos

y Dédalo de dibujos,

que impune usurpa los rayos,

que surca vientos seguro

(Cruz, 1957, p. 403) 
If the first emblematic figure chosen by sor Juana is more relatable to the political situation at that time thanks to the image of the power (in the form of fire) stolen and usurped, the second, Dedalus, plays a more fundamental role in this analysis. Of course, deciphering an emblem and a hieroglyph is nothing else than a search for the right path through a labyrinth of cross-references. The reader of El Neptuno Alegórico has to find a way to connect the emblem and the hieroglyph to their allegorical meaning. The route to understanding the emblems and the hieroglyphs is traced and indicated by the author, starting from the external experience of the triumphal arch, proceeding through the arch and arriving beyond, at the textual description, thus immediately pointing toward something that exceeds the sign and is located outside the labyrinth. Therefore, in this labyrinth, the reader takes up the roles of both Theseus and Ariadne, following a thread that comes from a space existing before the arch (the meaning of the allegories) while also overcoming that same space (the explanation of this meaning). Everything that the reader encounters on this journey defers to a preceding sign.

In this way, sor Juana does not simply create an architectural structure that she then explains within a literary text. Rather, to a certain extent, the text itself participates in the architectonical structure. To better understand what I mean by this, one needs to remember that the relevance of El Neptuno Alegórico is not only related to its historical or political value: There is also a specific feature of the text that makes its presence unavoidable in a study about subjectivity and writing in the context of sor Juana's oeuvre. Indeed, El Neptuno Alegórico and the text of El Theatro de virtudes políticas by Sigüenza y Góngora are two rare examples of descriptions of triumphal arches built during the 
sixteenth and seventeenth century. ${ }^{11}$ In his essay “"La erudición elegante': Observations on the Emblematic Tradition in Sor Juana's 'Neptuno Alegórico' and Sigüenza's 'Teatro de Virtudes Políticas"”, Joseph Jones (1979, p. 57) points out:

The study of the civic festivities like the one in which Sor Juana and Dr. Sigüenza played a meaningful part is difficult for the obvious reason that virtually all that remains of them is a small body of descriptions (such as the two discussed here), languid occasional poetry, and a few rare paintings or engravings. The parades, floats, fireworks, tournaments, music, ballets, hangings, flowers, temporary theatre and stadium, wooden monuments and outdoor altars, special religious celebrations, and sermons, speeches, banquets, parties and an infinite number of other manifestations which are partly ritualistic (one might say) and partly artistic, have all disappeared forever. (Jones, 1979, p. 57, emphasis added)

In Jones's quote above, I would like to emphasize the ephemeral nature of the celebrations and the virtual nature of those that remain or, in other words, of those that survive. From this perspective, El Neptuno Alegórico acquires its own subjectivity, yet the presence of such quotes that sor Juana inserts in the text does not represent the occasion only from the perspective of a philological interrogation about who actually said what. When we consider the text as an act of testimony - the account of an event that would otherwise have disappeared - it acquires a more fascinating status. The text continues to point toward something (the arch) that no longer exists, forcing the timeline to recede and thus escaping the supposed present in which the subject supposedly lives.

\footnotetext{
${ }^{11}$ Carlos de Sigüenza y Góngora (1645-1700) was a friend of sor Juana and a famous novohispano intellectual responsible for the construction of a second triumphal arch also erected to welcome the viceroys in 1680. El Theatro de virtudes politicas is the description of Sigüenza y Góngora's arch.
} 
The emergence of this spectral El Neptuno Alegórico, in the relationship between El Neptuno Alegórico (the arch) and El Neptuno Alegórico (the literary text), marks the passage from the substantial nature of the subject to a semiotic and textual subject. While the substantial subject pre-exists the language and writing (so that a deixis can point directly to it), the semiotic and textual subject is constituted through language and writing (so that the deixis triggers an endless chain of interpretations). This passage, from substantial subject to textual subject, is a passage in which the subject, for being written, needs an interpretation and an external reading by "the other" in order to exist. In this sense, the subject does not occupy only its present, but also the possible future of the interpretations. Derrida (1994) refers to this phenomenon as a "specter", in which a text survives its own present via decontextualization and re-signification.

\section{Cryptographies}

How can this passage from substantial subject to semiotic and textual subject be possible? To answer this question, it is first necessary to reflect on the procedures adopted by sor Juana and what happens when the subject is considered as a sign- that is to say, as something that does not precede language, but rather, is constituted by language.

As stated previously, the procedure adopted by sor Juana consists of a deferral of the referent. The act of quoting, so intense and crucial, exemplifies a recurring displacement of the voice of the author, undermining the central position of the "I" as the only source of authorial and authoritative truth within the text. This "I" often indicates and quotes another text. Furthermore, another step is to reconsider the action of using emblema. In an emblema, the signifier does not represent directly its object, showing it "as such", like a deixis does, but only indirectly, thus leaving part of this object unsaid. 
According to sor Juana, the feeling of not being able to fully grasp the reference of the sign allows the possibility at least of speaking of something that cannot be named using a univocal category.

This intent is clearly stated in the incipit of El Neptuno Alegórico. I would claim that the spectral dimension of writing takes root, not only in the explicit (and incidental) function of the text remembered by Jones, as quoted above, as that which remains (or not remains) of the arch, its specter, but also in the very words of the incipit:

Excelentísimo Señor: Costumbre fue de la antigüedad, y muy especialmente de los egipcios, adorar sus deidades debajo de diferentes jeroglíficos y formas varias: y así a Dios solían representar en un círculo, como lo escribe Pierio Valeriano: Aegiptj Deum ex hieroglyphico circuli intelligebant, por ser Symbolo de lo infinito. Otras veces, en el que llamaban Eneph, por quien entendían al Criador del Universo, [...] No porque juzgasen que la Deidad, siendo infinita, pudiera estrecharse a la figura y término de cuantidad limitada; sino porque, como eran cosas que carecian de toda forma visible, y por consiguiente, imposibles de mostrarse a los ojos de los hombres (los cuales, por la mayor parte, sólo tienen por empleo de la voluntad el que es objeto de los ojos), fue necesario buscarles jeroglificos, que por similitud, ya que no por perfecta imagen, las representasen. Y esto hicieron no sólo con las deidades, pero con todas las cosas invisibles, cuales eran los días, meses y semanas, etc., y también con las de quienes era la copia difícil o no muy agradable, como la de los elementos [...], y así de todo lo demás. (Cruz, 1957, p. 355-56, emphasis added) 
This opening paragraph of El Neptuno Alegórico immediately introduces the reader to hieroglyphic writing and to the question of writing itself. In the quote, sor Juana defines the hieroglyph as a strategy to represent deities, since deities are impossible for mortals to see (imposibles de monstrarse a los ojos de los hombres). For this reason, it is necessary to use a sign or an image (emblem) that, even if imperfect, is able to represent them. Expanding upon this point, sor Juana explains how mortals use this technique, not only with deities, but with all "invisible" things—-days, months, or weeks (cuales eran los dias, meses y semanas) or elements that are "difficult to copy" (con las de quienes era la copia dificil). This quote by sor Juana offers three different approaches to the use of the emblem in writing.

The first approach looks at the context beyond the literary text. El Neptuno Alegórico provides an explanation of the emblems that are not represented within the text, but on the arch. This first and obvious passage implements a semiotic "scavenger hunt" in which each sign contains traces of the next. The second approach focuses on the description of a movement out of the sign. In the quote (above), sor Juana emphasizes how Egyptians used hieroglyphs to express two different types of objects: those that are invisible because they are infinite, and those that are invisible because their referent is not corporeal. What these two types of objects share, is the impossibility of being captured in processes of representation. An interesting aspect of this impossibility is that it is not linked with the action of depicting or painting something, but rather with the action of writing down a concept. At the same time, the meaning exceeds the sign, or in other words, the greater the excess of meaning, the more a hieroglyph becomes necessary, as otherwise the existence of the objects they represent would escape mortals entirely. The final approach transforms the entire text into a hieroglyph that has as its signified a 
signifier (the canvas of the arch) that is not present in the text. This means that in the moment the text is transformed into a hieroglyph, it becomes "the signifier of a signifier" (Derrida, 1974, p. 7). In other words, it is a signifier that refers indefinitely to other signifiers in an infinite semiosis. Therefore, El Neptuno Alegórico is the representation of a representation. It is imprecise and far from perfect, not because of some false modesty on the part of the author, but because of the divine nature of the subject: the Roman god Neptune, who serves as an allegory for the viceroy that is, in its turn, an "allegory" for Spanish imperial power. This play of reminders in which the signified is never definitively reached and grasped, undermines the structuralist definitions of signifiers and signified, positing sor Juana's texts, not only in the canon of baroque literature, but also, due to this clever use of baroque rhetoric, in the corpus of literary texts that offer a valuable way to understand and explain the poststructuralist approach to both interpretation and writing.

According to José Pascual Buxó (2002), sor Juana does not recognize the ontic and hermetic dimension of the hieroglyph, relying instead on the difference between "similarity" and "image" as stated by Thomas Aquinas:

Atendiendo, sin duda, las lecciones de Santo Tomás, establece una neta diferencia entre "semejanza" e "imagen" que debe ser recordada a fin de comprender mejor las ideas de nuestra poetisa sobre los problemas relativos a la naturaleza de los signos y, en particular, de la mimesis icónica o representación por medio de imágenes de ciertos contenidos intelectuales. (Pascual Buxó, 2002, p. 135) ${ }^{12}$

\footnotetext{
12 "Following, doubtlessly, the lessons by Aquinas, she establishes a clear difference between 'similarity' and 'image' that we need always to bear in mind if we are to better understand the ideas of our poet concerning the nature of signs, and in particular, concerning the iconic mimesis, or representation through images, of certain intellectual contents" (translation by the author).
} 
Following José Pascual Buxó, the link between the Roman god Neptune and the Marquess de la Laguna relies, not only on the similarity between the marine nature of the god and the name of the viceroy (Laguna means lake or lagoon in Spanish), but also, as sor Juana states, on the impossibility of reducing the nature of the Marquess to anything less than a god. In this way, the Marquess becomes more noble, perfect, and thus exceeds the allegory. This represents a peculiar kind of baroque "concept" which, in the words of Pascual Buxó (2002), could be referred to as "conceptar con sutileza"- the creation of tropes, or conceits using subtleties. According to Buxó (2002, p. 142), El Neptuno Alegórico is not only a triumphal political machine, but also a revindication of the will of the Mexicans, in particular of the criollos.

\section{The Fluidification of the Substance of the Subject}

Pascual Buxó closes his chapter dedicated to El Neptuno Alegórico arguing that within the intricate metaphors of the arch, sor Juana hides the expectations of the criollo people, and in doing so, is able to overcome the tautological celebration of the viceroy expressed by these types of rituals and vassalages. In a recent essay dedicated to El Neptuno Alegórico, Beatriz Colombi (2017) argues that sor Juana was extremely deft in her handling of a code that, via images and inscriptions, allows her to express both explicit and hidden messages:

Sor Juana demuestra un admirable dominio de ese lenguaje cifrado que cruzaba inscripciones y colores, letras y formas, inscriptio y pictura, y era consciente de 
la versatilidad de un código que le permitía comunicar mensajes tanto explícitos como encubiertos. (Colombi, 2017, p. 72) ${ }^{13}$

The same annotation appears in the essay by Electa Arenal (2005), entitled "Del Emblema al Poema: Leyendo como una mujer la imagen de la mujer", in which she briefly quotes Jean-Michel Wissmer, stating: “Como dijera escuetamente Jean-Michel Wissmer: 'La monja sabe manipular sus textos y esconder su mensaje” (“As Jean-Michel Wissmer would clearly state: 'The nun knows how to manipulate her texts and hide her message"”; Arenal, 2005, p. 21). In fact, hiding the message does not imply a covering of the message under the words, but rather within the words, folding each sign several times. Each fold corresponds to a deferral of meaning from a specific level of interpretation, from the position of the signifier (the arch, the emblem, the hieroglyph, or the literary text), to a new level and a new position.

To better understand how the text of El Neptuno Alegórico-which was in fact also referred to as dédalo (the labyrinth) by sor Juana-can be deciphered in a cryptographic context, I turn to the words of Gilles Deleuze (1993) and his opening to Le Pli (The Fold). In the following quote, it is also possible to discern some interesting characterizations of the figuration of the labyrinth that clarify its central importance to the analysis presented in this chapter:

A labyrinth is said, etymologically, to be multiple because it contains many folds. The multiple is not only what has many parts but also what is folded in many ways. A

\footnotetext{
13 "Sor Juana shows an admirable command of this ciphered language that encompassed inscriptions and colors, letters and forms, inscriptio and pictura, and she was aware of the versatility of a code that allows her to communicate both explicit and hidden messages" (translation by the author).
} 
labyrinth corresponds exactly to each level: the continuous labyrinth in matter and its parts, the labyrinth of freedom in the soul and its predicates. If Descartes did not know how to get through the labyrinth, it was because he sought its secrets of continuity in rectilinear tracks, and the secret of liberty in a rectitude of the soul. He knew the inclension of the soul as little as he did the curvature of matter. A "cryptographer" is needed, someone who can at once account for nature and decipher the soul, who can peer into the crannies of matter and read into the folds of the soul. (Deleuze, 1993, p. 3 emphasis added)

The key elements that I would like to underline are the multiplicity of the labyrinth, the curvatures of both soul and matter, and the need for a cryptography that dénombre [accounts for] nature and déchiffre [deciphers] the soul.

In Deleuze's terms, multiplicity does not imply that the labyrinth is composed of multiple pieces, but rather that it is folded in different ways. This first element emphasizes the main feature of the subject deconstructed by El Neptuno Alegórico - that the subject is both unvarying and invariable. Similarly, emphasizing the curvature of both soul and matter, the idea of the labyrinth helps to vanquish the borders between soul and mattera task that in El Neptuno Alegórico is explicitly attributed to the rhetorical process of "reducing" the invisible idea into a visible hieroglyph. The final point that Deleuze raises, and that is of the utmost importance to my reading El Neptuno Alegórico, is the manner in which the labyrinth answers the questions that Descartes was unable to resolve because he refused to adopt a labyrinthine approach to soul and matter, in favor of a rectilinear approach. This solution marks the establishment of a cryptography able to count (dénombre) nature and to decipher (déchiffre) the soul. Zooming in on these terms, it is interesting to note that, alongside their meaning to count and to decipher, by re-thinking 
the prefix de- in the sense of privation (dé-nombre and dé-chiffre), it is possible to translate the French verbs differently. In this way, it is possible to imagine how cryptography helps us to deprive nature of its numbers, thus making it innumerable (sans nombre), and deprive the soul of its symbols (sans chiffre). Cryptography thus reveals its presence in El Neptuno Alegórico when the allegorical mechanism connects images of determinate ideas to figures that differ from those we might expect.

Furthermore, the "Dédalo de dibujos" (Dedalus made of canvas) maintains a degree of conceptual coherence with the fluid element because both labyrinth and water share a (very) baroque rhetoric behavior: They can easily change their shape. Concerning this coherence, the words that Deleuze dedicates to the "wave" as another representation of the fold, doing reference here to the letters to Des Billettes by Leibniz, is particularly productive:

Matter thus offers an infinitely porous, spongy, or cavernous texture without emptiness, caverns endlessly contained in other caverns: no matter how small, each body contains a world pierced with irregular passages, surrounded and penetrated by an increasingly vaporous fluid, the totality of the universe resembling a "pond of matter in which there exist different flows and waves". (Deleuze, 1993, p. 5)

The waves and flows described above also take the form of material folds: "[T]hat is why the continuous is a labyrinth that cannot be represented by a straight line. The straight line always has to be intermingled with curved lines" (Deleuze, 1993, p. 17). The form of the labyrinth and the form of waves are both characterized by curves - the baroque 
form par excellence. Thus, water is the element that flows throughout the text of $E l$ Neptuno Alegórico, steadily connecting the labyrinth to the text and signaling the importance assigned to this figuration. In sor Juana's work, it forms the link between the baroque depiction of reality and the transformation of the substantial subject into a sign. Because of this specific feature - the fluidity of the subject — the text differs from what Foucault calls discours (Foucault, 1970). Indeed, the text is configured and exists in a dimension other than that in which the discourse lives. This discourse, interpreted from a Foucauldian perspective, is what, according to the reproduction of power (Foucault, 1971, 1976), produces subjects. Underlining this difference between text and discourse, it is helpful to understand that the subject of the text, and the text as a subject, do not refer to socio-political labels that adhere to categories associated with belonging. The subject of the text in El Neptuno Alegórico is not individuated by political signifiers such as criollos or criollas, Peninsular Spanish, or indigenous people. On the contrary, when the subject changes its own nature and becomes fluid and variable, it is impossible to think about a subject trapped within or seized by power relations because it constantly avoids occupying any fixed position that is easy to define.

This distance that I signal, between the subject locked into static categories and the subject as a sign, is useful if we wish to establish an irreducible différance characterized by what I have called a deferral that from this point on has to be thought, in Derridean terms, neither as a delay, nor a difference. As Derrida (1994) points out in Specters of Marx:

Is there that differance, if it remains irreducible, irreducibly required by the spacing of any promise and by the future-to-come that comes to open it, does not mean only (as some people have too often believed and so naively) deferral, 
lateness, delay, postponement. In the incoercible differance the here-now unfurls. Without lateness, without delay, but without presence, it is the precipitation of an absolute singularity, singular because differing, precisely [justement], and always other, binding itself necessarily to the form of the instant, in imminence and in urgency: even if it moves toward what remains to come, there is the pledge [gage] (promise, engagement, injunction and response to the injunction and so forth). The pledge is given here and now, even before, perhaps, a decision confirms it. It thus responds without delay to the demand of justice. The latter by definition is impatient, uncompromising, and unconditional. (Derrida, 1994, p. 37)

The sign therefore has to be fluid, because fluidity represents the only possibility for the subject to become a sign without claiming a strong substantial identity. That which is fluid-like water or the folds of the labyrinth — cannot be the source of a strong voice, but only of a voice that "weasels its way" into the text. While the subject of the (Foucauldian) discourse is declared in its sameness and subjected to labelling, the subject as sign, conversely, refuses to belong to any category and constantly opens up the text to the possibility to look at the subject as other, thus overcoming any idea of the subject as the same. For this reason, writes sor Juana, a woman's voice, her voice, is revealed to be the most appropriate to compose the triumphal arch. ${ }^{14}$

Here, it is interesting to learn what El Neptuno Alegórico says about the choice of a woman to compose such an important work. Simultaneously, the same passage also explains something more about the decision and necessity to introduce so many quotes in the text. In the section entitled Razón de la fábrica alegórica, y aplicación de la fábula, sor Juana depicts the female voice as soft and thin. However, instead of deploying a

\footnotetext{
${ }^{14}$ Sor Juana refers here to the biblical episode of the Tecuite, the woman from Tekoa, in Samuel 2: 14.
} 
classical strategy of modesty, the reason why she did not decline the request to compose the arch (as would be expected from a woman at that time) was not motivated by theperhaps expected - argument that she is writing notwithstanding her sex and its correlated weaknesses. To the contrary, sor Juana claims that she is writing because of the weaknesses of her sex. Moreover, she adds a reason why she could have justified declining, which is surprisingly related neither to sex, nor to modesty, but to the excess of the request itself:

Ha sido el lucimiento de los arcos triunfales erigidos en obsequio de los señores virreyes que han entrado a gobernar este nobilísimo reino, desvelo de las más bien cortadas plumas de sus lucidos ingenios [...] según lo cual, la mía estaba bastantemente excusada de tan alto asunto y tan desigual a mi insuficiencia, cuando el mismo Cicerón, padre de las elocuencias, temía tanto la censura de los lectores, que juzgaba todos los extremos en ellos peligrosos, buscando la mediocridad [...]. Causas que me hubieran motivado a excusarme de tanto empeño, (Cruz, 1957, p. 357, emphasis added)

The lines about the fluidity of the female voice follow immediately after: "le pareció que era [...] más apta la blandura inculta de una mujer que la elocuencia de tantas y tantas doctas plumas" (p. 358, emphasis added). The soft and thin materiality of the female voice offers a double cue here. On the one hand, the reference to this kind of materiality leads us to imagine a voice that does not have enough density to acquire a specific shape and, therefore, a specific identity (la blandura inculta de una mujer). On the other hand, and as a direct result of the first, the lack of a solid and rigid materiality-i.e. the lack of substantiality - makes it possible to decrease the value of the presence of a labelled, 
unvarying, and solid subject. The absence of a strong presence of the subject, embodied in the word "I", writes off the operation of creating a simultaneous link between what is said and by whom - a link based mainly on the univocal possibility of speaking the truth. For this reason, a fluid, soft, thin voice that "weasels its way in" introduces the opportunity of changing its own subjective and unrepeatable nature from a substantial to a semiotic subject, and from a solid authorship linked to the idea of an unchangeable and recognizable author to a communion of voices that can easily exchange their place with that (once) occupied by the only possible author.

In doing so, the action of quoting acquires multiple and interesting features. Sor Juana declares explicitly that the softness of the female tongue (referring to the biblical episode of the woman from Tekoa) is a strategy to oppose the fury of the king with a "thin subject" that easily avoids becoming a target:

[...] industria que usó el Capitán Joab en el perdón de Absalón con la ofendida Majestad de David, conseguido por medio de la Tecuites, no porque juzgase más eficaces los mentidos sollozos de una mujer no conocida, ignorante, y pobre, que su autoridad, elocuencia y valimiento, sino porque el rayo de la ira real incitada a los recuerdos del delito, no hiciera operación en el sujeto flaco, pues éste busca siempre resistencia para ejecutar sus estragos [...] (Cruz, 1957, p. 358, emphasis added)

The "thin subject" (el sujeto flaco) is so thin that it is almost impossible to be individuated, and hence does not need strong arguments to be effective: 
Y que la confianza fuese en la piedad a que movería el sujeto y no en la fuerza en la piedad a que movería el sujeto y no en la fuerza de los argumentos, se conoce del mismo sagrado texto, que confesó ella misma no ser suyas aquellas palabras [...]. (Cruz, 1957, p. 358, emphasis added)

The thin and fluid nature of the female subject permits the removal of substance from its voice, and the addition of semiotic matter to it. To understand this, it can be useful to think about this complex configuration of the subject following what Jacques Derrida (1995, p. 91) writes about the Platonic khora: "But on the one hand it is always difficult, particularly in Plato, to separate the two problematics: the quality of the discourse depends primarily on the quality of the being of which it speaks." At this point, it is interesting to consider the Platonic issue of the khôra. Plato explains what khôra is in a passage of Timaeus (Plato, 2009, p. 39). Khôra is both space and matter-in a word, a receptacle. Similar to our fluid subject, khôra is a concept likened to a surface that can receive an impression, matter that can be molded into a shape, or a mother that can produce an offspring - examples that underline the notion of khôra as a third genre (triton genos; Plato, 2009, p. 23); something that can be transformed, or a space for becoming.

Moreover, the issue of losing a clear identification of labelled spaces of belonging affects the possibilities of both recognizing and representing the subject. As Derrida (1995) points out, when the khorra refuses to belong, to be built up starting from “oppositions «platoniciennes»", it limits the opposition between the model (eidos) and the copy (image): 
But there is a point, it seems, where the relevance of this rhetorical code meets a limit and must be questioned as such, must become a theme and cease to be merely operative. It is precisely the point where the concepts of this rhetoric appear to be constructed on the basis of "Platonic" oppositions (intelligible/sensible, being as eidos/image, etc.), oppositions from which khôra precisely escapes. The apparent multiplicity of metaphors (or also of mythemes in general) signifies in these places not only that the proper meaning can only become intelligible via these detours, but that the opposition between the proper and the figurative, without losing all value, encounters here a limit. (Derrida, 1995, p. 147)

Of course, the notion of the limit does not appear explicitly in sor Juana's text. However, the way in which sor Juana connects the figuration of the "thin subject" with the question of representation is the delineation of this limit and the simultaneous action of overcoming it, playing, as in Derrida's quote, into the space of the proper and the figurative:

Y ya dispuesta la voluntad a obedecer, quiso el discurso no salir del método tan aprobado de elegir idea en que delinear las proezas del héroe que se celebra, o ya porque entre las sombras de lo fingido campean más luces de lo verdadero [...], o ya porque sea decoro copiar del reflejo, como en un cristal, las perfecciones que son inaccesibles en el original: [...] o ya porque en la comparación resaltan más las perfecciones que se copian [...] y así ninguna cosa vemos insigne (aun en las sagradas letras) a quien no hayan precedido diversas figuras que como en dibujo la representen. (Cruz, 1957, p. 358-59, emphasis added) 
In this excerpt, sor Juana describes the creation of the hieroglyph, emphasizing that "among the shadows of what is false there are more lights than in what is true" ("entre las sombras de lo fingido campean más luces de lo verdadero"), meaning that there is not a stable difference between a reproduction and the original. In this way, the polarity between the signifier and the signified is also affected, since the signifier is not an imperfect reduction of the signified, but reveals itself to have "more lights" than what is considered to be its real referent.

This impossible limit between the model and the copy is better understood by placing the works of Derrida and sor Juana into a constructive dialogue, as seen below via the following passage from Khôra:

Giving place to oppositions, it would itself submit to any reversal. And this, which is another consequence, would not be because it would inalterably be itself beyond its name but because in carrying beyond the polarity of sense (metaphorical or proper), it would no longer belong to the horizon of sense, nor to that of meaning as the meaning of being. (Derrida, 1995, pp. 92-93)

At this point it is crucial to add a last and fundamental consideration about the anachronic condition of the khôra because this consideration discloses the connection between cryptography and spectrography. In the following quote, Derrida explains that the khora anachronizes being:

It would be a matter of a structure and not of some essence of the khora, since the question of essence no longer has any meaning with regard to it. Not having an essence, how could the khora be [se tiendrait-elle] beyond its name? The 
khorra is anachronistic; it "is" the anachrony within being, or better: the anachrony of being. It anachronizes being. (Derrida, 1995, p. 94)

The connection is subtle and almost invisible, but steadily linked with the axes of the first part of this chapter: the labyrinth; the fluidification of substance into sign; the decrease of individual identity lost into a generical "voice of the author"; the impossibility of having simultaneity between the original idea and its representation (although, as sor Juana underlines, this impossibility does not affect the "quality" of the representation). Each one of these operations creates a detachment from the temporal and the essential level of the "subject", transforming the text into a specter - that is to say, an entity that, like the khôra, anachronizes time. The large number of quotes in El Neptuno Alegórico poses the question: "Who (the essence) is speaking, and at what time?" It represents a constant erosion of the presence of the authentic voice of the subject. This erosion is the result of the contact between the idea of the subject and the idea of the specter, understood as something that lacks substance and anachronizes time via the constant deferral of the signified. Erosion here consists of a rarefaction of the strength and solidity of the subjective voice and results in a displacement of the impact of the affirmation of the word "I". This attempt to rarefy the strength and solidity of the subject, fulfilled via the previously mentioned strategies of quoting other voices, bending their meaning, and interrogating the possibilities of representation, provokes the deployment of a subversive "strategy of modesty" in which the sex of the subject does not use the male voice to reinforce its authority but, on the contrary, the male subject needs a female voice to subvert the role of "authority". The next sections will explain what I mean by the term "specter" in sor Juana's texts; how spectrality is connected with the issue of knowledge in El Neptuno Alegórico and in Primero Sueño; and how the entanglement between sex 
and the subject is created, hence introducing, beyond the topic of cryptography, the topic of "spectrography".

\section{From Cryptography to "Spectrography"}

In the conclusion of the previous paragraph, I focused on the labyrinth, specifically what Gilles Deleuze proposes regarding the figure of the labyrinth during the baroque era, and from the perspective of a philosophy of the baroque. The final paragraphs placed Derrida and sor Juana into a constructive dialogue about the process of representation and the impossible essence of the subject. Throughout the dialogue with Deleuze, it has been possible to highlight the cryptographical element that prevails in El Neptuno Alegórico. Indeed, in many passages of El Neptuno Alegórico, sor Juana demonstrates that the allegorical meaning of the figures depicted on the arch needs further explanation, revealing a cryptographical space between the original idea, the allegorical meaning, and that explanation. This space it is not only useful to maintain a degree of separation that facilitates the comprehension of the allegory, but also the comprehension of each particular emblem.

In the following, I focus on what I call spectrography. Although only marginally touched upon in El Neptuno Alegórico, the concept plays a central role in Primero Sueño. In El Neptuno Alegórico, the question of spectrality appears because, in this text, the subject is deprived of its substantiality and strength, since it is often "occupied" by an extraneous voice that threatens the authenticity and the originality of the voice of the author. It is possible to perceive this strategy of deferral as a first attempt by sor Juana to deprive the subject of its substance and, in this way, to affirm that the subject is not the only source of truth. The constant presence of water and the other fluid elements that 
occur in El Neptuno Alegórico, each performing different rhetorical functions (metaphors, representations, features of matter), is a strategy via which to transform the space of connection between the propre and the figuré-that is, the space of cryptography_into a folded space, a labyrinth, in which the subject loses its substance to the space of "spectrography".

As a consequence, my reading of Primero Sueño will hinge on the Derridean concept of the specter. In Specters of Marx, Derrida (1994) describes the concept of the specter with the following words:

Nor does one see in flesh and blood this Thing that is not a thing, this Thing that is invisible between its apparitions, when it reappears. This Thing meanwhile looks at us and sees us not see it even when it is there. A spectral asymmetry interrupts here all specularity. It de-synchronizes, it recalls us to anachrony. (Derrida, 1994, p. 6)

When Derrida introduces the specter, he uses the Shakespearean specter of Hamlet. The gloomy atmosphere, the impossibility to see the specter and to "comprehend" its "presence", are the basis upon which to understand its characteristics. Similarly, the philosophical poem by sor Juana, Primero Sueño, opens, as we will see, with the same dark atmosphere. During the two nocturnal moments - in Hamlet's scene described by Derrida in Specters of Marx (1994, p. 1), and in Primero Sueño's opening - the night is an element that confuses and disorientates. The night obscures all that is "clear" and "distinct", and that characterizes the metaphysical idea of the subject. In fact, in Primero Sueño, the subject (which appears only at the very end of the dream) is neither the metaphysical subject, nor completely what she calls a "soul", caught in the process of 
knowing. Rather, it is a subject that oscillates between being a sudden appearance, like the specter in the famous nocturnal Hamlet's scene, and being "a Thing that is not a thing", as Derrida suggests in the quoted above.

While in El Neptuno Alegórico sor Juana dissolves the substance of subject, the nocturnal disorientation of Primero Sueño threatens another fundamental feature of the metaphysical idea of the subject, namely the fact that it is centered on its own presencea presence that unavoidably moves from the past to the future in a continuous temporal flow. In fact, the concept of the specter undermines this type of presence because the subject loses, not only its substantiality, but also its power to control both its past and its future. Indeed, the specter in Derrida represents a past that does not pass, interrupting the "regular" linearity of the flow of consciousness. Contesting the substantiality of the subject and the centrality of presence, sor Juana delivers a double blow to the metaphysical subject. As I will demonstrate in the final section of this chapter, this double blow is essential to the introduction of the feminine.

\section{Primero Sueño: The Disjunction of Soul from Body and Mind, and the Entanglement of the Subject and Sex}

In her autobiographical account of 1691, sor Juana references Primero Sueño as un papelillo - that is to say, according to the English translation provided by Electa Arenal and Amanda Powell (Cruz, 1994), a "trifling thing". Following the same translation, the title of the poem is not Primero Sueño, but El Sueño (The Dream). Sor Juana wrote El Sueño toward the end of her life, somewhere between 1685 and 1691. The poem is a silva, which is a composition of hendecasyllables and heptasyllables of an indefinite number of lines, in this case 975. The 975 lines of El Sueño appeared for the first time under the 
following complete title: Primero Sueño, que así intituló y compuso la madre Juana Inés de la Cruz, imitando a Góngora. There is a striking similarity between the title of Primero Sueño and the famous silvas by Luis de Góngora, entitled Soledades: Primera Soledad and Segunda Soledad.

In the following, in accordance with the main theme of this chapter-the sexual revolution of the subject-I underline the salient points that will prove useful to our subsequent reading of Primero Sueño. The elements that sor Juana highlights in El Neptuno Alegórico-Neptune as a deity connected with silence and knowledge; the central role of Minerva; the figure of Dedalus (both as the father of Icarus and the architect of the labyrinth); the possibility of representation; the image of the building similar to the Tower of Babel; and the experiments of Athanasius Kircher - are all present in Primero Sueño, but here there is the clear addition of other elements, such as the leading role of the soul; the deeper uneasiness of a dismembered subject; and a general sensation of unconsciousness that paradoxically goes with the process of knowing and cognition.

Summarizing the plot, Primero Sueño narrates the story of a soul that, separated from its body during the night, embarks on a journey toward universal knowledge. The incipit of the poem establishes a nocturnal and ominous atmosphere during which a pyramidal shadow is cast by the earth:

Piramidal, funesta, de la tierra nacida sombra, al cielo encaminaba de vanos obeliscos punta altiva, escalar pretendiendo las estrellas; (Cruz, 2018, p. 257, lines 1-4, emphasis added) 
The shadow, la sombra, is the terrible first protagonist of the night. It moves toward the stars, as spectral matter declaring a "gloomy war", but the "arrogant" (altiva) tip of the pyramid does not reach even the nearest sky - that of the moon. ${ }^{15}$ For this reason, sor Juana imagines that the stars look at this "immodest" shadow from the height of the eighth sky, immune to its war and almost making fun of it (see verse 10: burlaban tan distantes):

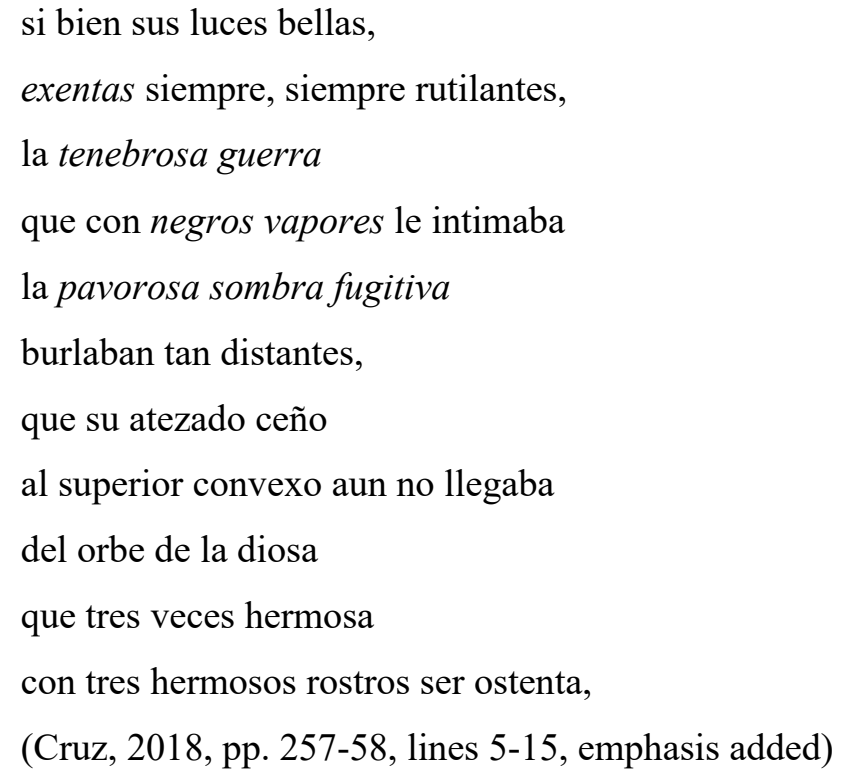

In the following verse, the poem describes the effects of night's shadow on an earth that appears as a quiet empire in which only nocturnal birds are awake. These "doomy" birds are the unique creatures allowed to sing a slow and funereal melody, interrupting the silence imposed during the hours of darkness. In this atmosphere, all other sentient beings (humans and animals) are paralyzed, and they sleep in a non-temporal space: neither dead, nor alive. In this moment, beyond human time, the soul remains temporally dead, in between life and death, beyond the control of the (sentient) subject.

y con siempre igual vara

\footnotetext{
${ }^{15}$ According to the Ptolemaic system, the first sky over the earth is the sky of the moon, while the stars occupy the eighth sky.
} 
(como, en efecto, imagen poderosa

de la muerte) Morfeo

el sayal mide igual con el brocado.

El alma, pues, suspensa

del exterior gobierno - en que, ocupada

en material empleo,

o bien o mal da el día por gastado - ,

solamente dispensa

remota, si del todo separada

no, a los de muerte temporal opresos

lánguidos miembros, sosegados huesos,

los gajes del calor vegetativo,

el cuerpo siendo, en sosegada calma,

un cadáver con alma,

muerto a la vida y a la muerte vivo,

de lo segundo dando tardas señas

el de reloj humano

vital volante que, si no con mano,

con arterial concierto, unas pequeñas

muestras, pulsando, manifiesta lento

de su bien regulado movimiento.

(Cruz, 2018, pp. 266-67, lines 188-209, emphasis added) ${ }^{16}$

The soul is represented in an intermediate state of existence, not separated completely from the body and therefore not dead, but freed from any corporeal chain and beyond the body's jurisdiction. Only the human heart, as a human clock (reloj humano), beats time to the night and remains active, while all other human organs are immobilized or, in the case of the stomach (centrifica oficina), in the process of digesting food, provoking the steam that will be the cause of the dream. The human body lies in silence and appears

\footnotetext{
${ }^{16}$ It is important to remember that "soul" (alma, in Spanish) is a feminine noun that, due to the fact that it begins with a tonic $a$, requires the definite article $e l$, instead of the more common article for feminine nouns $(l a)$.
} 
described not as a whole, but by its organs, by sense organs, and by functions, suggesting that the body is built from smaller pieces and is not an inseparable unitary form. While the body to which it is usually tied sleeps, the soul reaches the summit of a mountain. From this height, the soul is not forced to receive the images of the ideas, wisely depicted by the imagination with the "help" of the estimative faculty of the soul (cogitation), but it can reach knowledge directly from the universe that displays itself at the mountain's feet. Following medieval psychology, sor Juana separates the external sensorial faculties of the body (sight, hearing, touch, taste, and smell) from the inner sensorial faculties of the soul (common sense, imagination, estimative faculty, fantasy, and memory):

los simulacros que la estimativa

dio a la imaginativa

y aquésta, por custodia más segura,

en forma ya más pura

entregó a la memoria (que, oficiosa,

grabó tenaz y guarda cuidadosa),

sino que daban a la fantasía

lugar de que formase

imágenes diversas. [...]

así ella, sosegada, iba copiando

las imágenes todas de las cosas,

y el pincel invisible iba formando

de mentales, sin luz, siempre vistosas

colores, las figuras

no sólo ya de todas las criaturas

sublunares, mas aun también de aquellas

que intelectuales claras son estrellas,

y en el modo posible

que concebirse puede lo invisible,

en sí, mañosa, la representaba

y al alma las mostraba. 
(Cruz, 2018, pp. 269-71, lines 258-291, emphasis added)

Once again, in the quoted verses there appears the problem of representing that which is invisible, as we also encountered in El Neptuno Alegórico, when sor Juana commented that the hieroglyphs were a system to make visible what would otherwise remain invisible. Here in Primero Sueño, it is possible to find the description of the moment that precedes the occurrence of the sign. According to the lines by sor Juana, it is possible to conceive what is invisible and represent intellectual concepts ("invisible ideas") by using an invisible paintbrush to depict them. Here, we must revisit the atmosphere evoked by Primero Sueño: Not only is there a lack of sound and a triumph of silence, indicated by the image of Harpocrates, the Greek god of silence who appears at the beginning of the poem sealing his lips with his index finger, and by the opening verses with their stress on quietness, but also a lack of light and the triumph of darkness and obscurity. ${ }^{17}$ In darkness everything becomes invisible and, similar to death and sleep, obscurity covers, without distinction, material and immaterial objects. The only permitted light is that of ideas which, like stars, show their clarity. Indeed, the internal sense of fantasy, compared to the Pharos of Alexandria, depicts the images of things in the darkness using an invisible paintbrush, while fantasy finally shows the images to the soul. ${ }^{18}$ Darkness is impartial:

\footnotetext{
${ }^{17}$ It is remarkable that the gesture of closing the mouth, symbolizing the imposition of silence and enacted by Harpocrates using his index finger, is precisely the opposite of the function of the hieroglyph-i.e., the indication of a meaning that eludes the hieroglyph, but that is recalled, despite its material absence and irrepresentability, by the hieroglyph. Harpocrates also appears in El Neptuno Alegórico.

${ }^{18}$ The following verses refer to two pyramids made of light and dedicated to Homerus. Martha Lilia Tenorio (Cruz, 2018, p. 273) finds no satisfactory justification for this striking image of the double pyramids, and the reference made to Homerus is classified as an error since Homerus never spoke about pyramids in his work. However, considering the alliteration of the word "pyramid" with the Ancient Greek words "pyr" (fire), and "eidos" (image), it is possible to imagine the two pyramids, not only as the Egyptian ones, but also as the double flames that in Dante Alighieri's Divine Comedy represent Ulysses and Diomedes. I argue this interpretation can be supported, not only because Dante's Divine Comedy circulates between, and influences, other poets known to sor Juana, but also because Dante collocates the two souls in Hell. This is because they behaved outrageously toward the agreed limits of human knowledge and their punishment is thus relatable to the argument of sor Juana's verses, since they are reduced to fire according to the law of
} 
What is visible during the day becomes invisible; and what is already invisible in daylight becomes doubly invisible. This passage of Primero Sueño is dedicated to a first example of a theory of knowledge. The faculties of mind involved in this theory of knowledge, like mind and soul, are all terms that in Spanish agree with the feminine. This is interesting because the female subject ("I") that closes the poem underlines once more this tendency of sor Juana to attribute to the female gender all the features involved in cognition.

Returning now to Primero Sueño, the soul is freed from its corporeal chains, turned into its immaterial essence, and observes the whole of reality without the possibility of comprehending it because of its complexity:

\author{
cuyo inmenso agregado, \\ cúmulo incomprehensible, \\ aunque a la vista quiso manifiesto \\ das señas de posible, \\ a la comprehensión no, que, entorpecida \\ con la sobra de objetos, y excedida \\ de la grandeza de ellos su potencia, \\ retrocedió cobarde. \\ Tanto no, del osado presupuesto \\ revocó la intención, arrepentida, \\ la vista que intentó, descomedida, \\ en vano hacer alarde \\ contra objeto que excede en excelencia \\ las líneas visüales \\ $[\ldots]$ \\ como el entendimiento, aquí vencido \\ no menos de la inmensa muchedumbre
}

retaliation: As they dared to see more than permitted, now they cannot be seen for the light that traps their souls. 
de tanta maquinosa pesadumbre

$[\ldots]$

y por mirarlo todo, nada vía,

(Cruz, 2018, pp. 278-79, lines 448-480, emphasis added)

The faculties of understanding and comprehension appear defeated. Moreover, among all these objects, there are also objects for which it is impossible to retain an image. An example here is the object upon which, by definition, it is impossible to gaze: the sun ("objeto que excede en excelencia / las lineas visuales"). The soul, blinded by the excess of objects, is admiring what it sees, almost in a Cartesian sense of the action, but then suddenly recovers its faculties and decides to methodically approach these myriad objects. The method, similar once more to the Cartesian method, starts with a simplification of the vast variety of things and their distribution into Aristotelian categories. ${ }^{19}$

However, first, it is important to conclude the adventure of the soul and observe how sor Juana creates the condition for the subject to affirm itself. Up to this point, it is clear that the soul, as well as the sleeping human body, is addressed in the third person. Therefore, the poem's narration reveals neither a personal nor an individual voice. However, in line 617, the impersonal and external voice of the narration interrupts the flow and presents its own singularity:

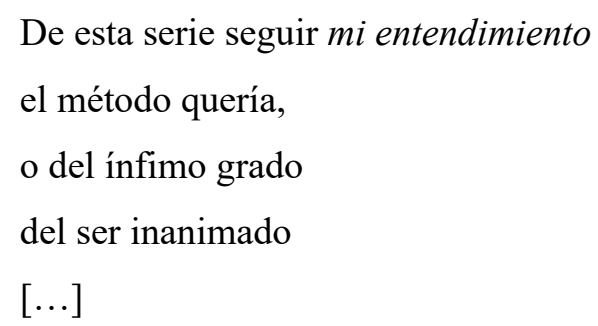

\footnotetext{
${ }^{19}$ In particular, sor Juana does reference explicitly the ten Aristotelian categories: substance; quantity; quality; relatives; somewhere; sometime; being in a position; having; acting; and being acted upon.
} 
pasar a la más noble jerarquía

(Cruz, 2018, pp. 284-85, lines 617-624, emphasis added)

The possessive pronoun "my" (mi entendimiento) indicates that the voice heard in this verse is not impersonal, but rather, starts exhibiting a mind of its own (entendimiento). ${ }^{20}$ The mind is isolated from the voice of the author, while the possessive adjective (mi) turns the direction of the poem toward an almost autobiographical space in which not only the intellect, but also the whole history of the dream (sueño) comes from the mind of an author — an "author" that never identifies him- or herself with human kind. In the following verses of Primero Sueño, the process of cognition reaches, species by species, in order of perfection, the most perfect creature: Man, el Hombre. Here, rather than "Man" acting as a universal term indicating the whole of human kind, there is a possibility that it refers specifically to a male person for two reasons. First, the poem refers to the Book of Genesis, and thus, the first human being was a man-Adam. Second, in other writings such as La Respuesta a Sor Filotea, sor Juana plays on the ambiguity of the term and sagaciously attributes to males all those sinful behaviors generically attributed to humans.

In addition to presenting the body, the soul, and their attendant faculties, another "character" that enters the poem is Thought (pensamiento). During the difficult process of cognition that started with knowing, starting with the simplest objects and finally arriving at Man—considered as the most marvelous creature — a "timid thought" repeats that the process cannot be successfully accomplished because the faculties of the most perfect creature, Man, are not enough to understand even the simplest things, and when this occurs, the discourse cowardly deflects and retreats itself. The process of acquiring

\footnotetext{
${ }^{20}$ The term entendimiento here refers to one of the three faculties of the soul: the mind (cf. De Anima, Aristotle, 2011; De Trinitate, Augustine of Hippo, 1991).
} 
knowledge of the whole of reality (naturaleza) is, therefore, heavier and more laborious than holding the world on one's shoulders, as Atlas does, and it exceeds the strength of Alcaeus (Heracles):

Pues si a un objeto solo - repetía

tímido el pensamiento -

huye el conocimiento

y cobarde el discurso se desvía;

si a especie segregada

- como de las demás independiente,

como sin relación considerada -

da las espaldas el entendimiento,

y asombrado el discurso se espeluza

del difícil certamen que rehúsa

acometer valiente,

porque teme, cobarde, comprehenderlo

o mal, o nunca, o tarde,

¿cómo en tan espantosa

máquina inmensa discurrir pudiera?

cuyo terrible incomportable peso

si ya en su centro mismo no estribara,

de Atlante a las espaldas agobiara,

de Alcides a las fuerzas excediera;

y el que fue de la esfera

bastante contrapeso,

pesada menos, menos ponderosa

su máquina juzgara, que la empresa

de investigar a la naturaleza.

(Cruz, 2018, pp. 291-92, lines 757-780, emphasis added) 
The end of the poem now approaches, and little by little, as the body slowly recovers its unity and awakens, the whole process of cognition is freed of its spectral matter of shadows and ghosts ( $Y$ del cerebro, ya desocupado, / las fantasmas huyeron):

\author{
Y del cerebro, ya desocupado, \\ las fantasmas huyeron \\ y, como de vapor leve formadas, \\ en fácil humo, en viento convertidas \\ su forma resolvieron.
}

(Así linterna mágica, pintadas

representa fingidas

en la blanca pared varias figuras.

de la sombra no menos ayudadas

que de la luz: que en trémulos reflejos

los competentes lejos guardando de la docta perspectiva,

en sus ciertas mensuras

de varias experiencias aprobadas,

la sombra fugitiva,

que en el mismo esplendor se desvanece,

cuerpo finge formado,

de todas dimensiones adornado.

cuando aun ser superficie no merece.)

(Cruz, 2018, pp. 295-96, lines 868-886, emphasis added)

In particular, sor Juana reveals in the quoted verses that the whole adventure of the soul and its faculties was a dream, a hallucination due to natural causes (natural beleño). The act of dreaming, caused by the steam produced during the process of digesting food, is compared to the effect of the magic lantern invented by Athanasius Kircher. The shadows that the lantern displays on the wall are the shadows of objects that do not exist, that are not present, hence convincing the reader of the poem that the process of cognition is not necessarily based on a direct contact between the subject and the object of the process, in 
the same way in which the Derridean specter was described as a shadow that bends timea violent bending that in Derrida's (1993, p. 37) words "interrupts time, disarticulates it, dislodges it, displaces it out of its natural lodging: "out of joint"' and thus prevents the regular flow of time.

Both spectral images - the Derridean specter and the specters that inhabit sor Juana's Primero Sueño - show that, contrary to what happens in the Platonic myth of the cave, shadows are not a projection of a Truth, the origin of which lies beyond the cave. According to this revolution of the process of cognition, the philosophically "cowardly" discourse retreats the moment it fails to reach unitarian knowledge, while the mind and the intellect are defeated, and the soul, despite all its good intentions, cannot achieve any universal knowledge because it is still anchored to the body. The poetic discourse, conversely, admits the multiplicity and difference of a subject that lies in sunlight, but does not coincide with the sun-that absolute light that, as we saw in the poem, is impossible to know. The sun is the ultimate and the highest image of the metaphysical subject—neutral, absolute, self-sufficient, unitary, self-instituted, and self-declaredwhile the world to which the new deconstructed subject is expected to belong, is described as something that, while receiving its light from the sun, is fundamentally different from it.

The last line of Primero Sueño offers a new figuration of the subject because, not only does the word "I" appear for the first time in the entire poem, but also the word "I" concurs with the female grammatical gender of the adjective despierta (awake) forming, in this way, an unexpected entanglement between sex and the subject:

que con luz judiciosa

de orden distributivo, repartiendo 
a las cosas visibles sus colores

iba, y restituyendo

entera a los sentidos exteriores

su operación, quedando a luz más cierta

el mundo iluminado, y yo despierta.

(Cruz, 2018, p. 299, lines 969-975, emphasis added)

The entanglement between sex and the subject, different from the unitary, abstract, and neutral subject that does not permit diversification, is constituted by the fact that the female "I" cannot be read as an "I" that adds its gender: It is an "I" that does not deflect itself as the philosophical discourse, but rather inflects itself or, in other words, folds itself and changes its shape. The point of inflection becomes that double point that Derrida (1993, p. 60) describes in the original French version of Spectres de Marx when he writes: "Point de différance sans altérité, point d'altérité sans singularité." In my opinion, Derrida plays here with the word point, meaning both "point" and "not"- - a word pun that notably disappears in the English translation, which reads: "No differance without alterity, no alterity without singularity" (Derrida, 1994, p. 37). In the same way, here the emergence of the female "I" acquires three possible meanings related to the French word point. First, the unexpected female adjective is the point that expresses la différance of the subject: its alterity, singularity, and temporal instantaneity ("here-now"). Second, the emergence of the feminine subject is also the point when the subject refuses neutral and abstract features because it is no longer the absolute, solid, eventually deflecting, and never inflecting subject. Indeed, as Derrida writes (1994, p. 37), if there is no alterity, there is no différance (represented here by the entanglement of sex and the subject). If there is no singularity, there is no alterity (i.e. the singular "I" congruent with the alterity of the female gender), and there is no singularity without the "here-now" (represented by 
the strong punctual moment in which the "I" awakes). Third, since this is the poem's final verse, this point is also the very end - the very point of Primero Sueño.

In this chapter, I presented my preliminary arguments that make possible the establishment of a link between the works of sor Juana Inés de la Cruz and the contemporary philosophical debate about the deconstruction of the metaphysical subject. One of the primary aims of this section was specifically not to trace a static standpoint from which to propose a monolithic reading of sor Juana's texts. Such an interpretation would be a respectful yet ultimately unproductive response to a methodology constituted by a list of definitions of the crucial keywords of the classical literary analysis (text, poem, genre, subject, etc.). In abandoning this static perspective, it has been possible to perceive the intertextual movements of sor Juana's text, besides other crucial issues related to the revolution of the subject: the semiotic turn and the comparison of the entanglement sex and the subject toward the end of Primero Sueño. I have shown how, in sor Juana's writing, the word "subject" is not perceived or related to as a delimitated semantic area. This polysemy was one of the moments in which the meaning of the word "subject" becomes folded because each of its various meanings is not a newly added feature, but a fold of its labyrinthine path across a cryptography that questions both its solidity and substantiality, as well as its property of being the sole source of Truth. This subversion of the subject is the first step in the upheaval mentioned in the title - an upheaval that also destabilizes and subverts the linguistic and structuralist definition of the subject.

At this point, it becomes evident that the question of the formation of the subject in sor Juana Inés de la Cruz's corpus is crucial, not only from the perspective of the history of literature (as an example of the manifestation of a female subject), but also from the perspective of the history of philosophy as a first and early interrogation of the 
metaphysical subject. Moreover, this cruciality of the subject does not only depend on the question posed by the confrontation between literature and philosophy that forms one of the central themes surrounding and crossing Sor Juana's corpus, but also depends on the questions that Sor Juana herself poses in her work. In accepting the second perspective, even if we recognize that the presence of the author would not create an insurmountable obstacle to subject formation, and that the narrative process creates a secondary problem in order to understand how this subject is formed, the profound absence of a structured character in sor Juana's works and the strong presence of allegorical and disguised meanings allow us to consider her corpus far beyond what we might expect from a narrative example.

Following Judith Butler's $(2015$, p.4) argument about the relationship between literary works and the theory of subject formation, this conflation of sor Juana's own critique of the subject within the text and the tension that arises out of the narrative text force us to think this perspective as the agreement "to occupy an impossible position, one that, perhaps, repeats the impossibility of the condition we seek to describe". Furthermore, it is important to underline that the "impossible position" and the "impossibility of the condition we seek to describe" are not only the expression of a condition that lives within the range of what can be done (Butler, 2015, p. 4) - to think the impossible as something that rests on the level of possibilities - but also establishes a new kind of relationship between truth, beings, and the truth of beings (cf. Derrida and Ferraris, 1997, p. 11). The meanings and experiences conveyed in Primero Sueño and El Neptuno Alegórico are never automatically or "naturally" related to the truth, and empiricism experiences one of its most profound (and probably unique) crises: that nothing is what it appears to be. For this reason, the problematics of the representation of 
the subject, especially from a baroque point of view, find their solution precisely in the moment they accept their impossibility.

This impossibility to define the subject will remain a central topic in the following chapters. In particular, in chapter two in which I will examine the impossible declension of the subject within sexual binarism (male, female) through a close reading of the poem Respondiendo a un caballero del Perú. 


\section{Second Chapter. Sor Juana and the Sexistence of Bodies}

\section{Introduction. Defining Sex: The Other Answer}

This chapter focuses on a crucial issue in sor Juana's oeuvre: the issue of sex. Why is the question of sex in sor Juana's texts so important today? The first reason is that to approach this question introduces into the contemporary debate about sex and gender a different perspective from which "sex" is neither a universal nor a natural attribute, and "gender" recovers its connection with the ancient Latin sense of "homogeneous group" or genre (Apter, 2013, p. 168; Cassin, 2014, p. 375). The second reason is related to the possibility to formulate an answer to the question "What is your sex?", which lies outside the binary options offered by the mainstream definition of sexual difference. While sor Juana Inés de la Cruz was neither a visionary nor capable of foreseeing the future of continental philosophy, I suggest that it is possible to provide a different interpretation of her oeuvre that goes beyond that which constituted a deep watershed in the history of philosophy, namely: the constitution and celebration of an almighty and unavoidable subject that, starting from its presence, defines both itself and otherness.

Throughout the first chapter, I demonstrated how, in sor Juana's writings, it is possible to detect an initial move toward a deep reconfiguration of the steady and solid idea of the subject. Through this move, I established a connection between the preCartesian era on the one hand, in which the subject is not strongly present, and continental philosophy on the other, which, during the 20th century, tried to criticize and deprive of its centrality the position of the subject understood in a metaphysical sense- a position that had been gaining ground in the 18 th and 19 th centuries. The primary theme of the 
first chapter was, indeed, the detection of a subject that is no longer central in its autonomous status, but instead lacks both substance and the power imparted by its occupation of a self-defining, absolute position. Second, the first chapter examined the relationship between sex and the subject, in which the sense of sex and the sense of the subject are obscured by sor Juana, who plays on the multiple senses of, and multiple possible referents for, the final feminine adjective that concludes the long philosophical poem Primero Sueño. Proceeding, in this second chapter, I analyzed the specific role played by sex in sor Juana's work and how the concept of sex is fundamentally entangled with the concept of existence.

If we imagine for a moment that we analyze and interpret sor Juana's poems using a theoretical framework that is centered on the classical idea of a steady and self-sufficient subject completely present to itself, the result would always be incapable of transcending any limit, thus reducing sor Juana's writings to mere biographical events. Such a move would only serve to subordinate her work to the definition of "what" she was, instead of "how" she writes. The historical context, the social context, the gender politics, and the distribution of knowledge in the 17th century are all examples of the limits that I propose to overcome by focusing on sor Juana's writing instead of her biography. I perceive the above contexts to be limits precisely because they are all centered on the assumption that there are factual and actual elements that put the act of reading into a frame- one that easily becomes a cage. While it is possible to overcome the limit of the historical context without abandoning a subject-centered position, the final reading will result only in a transposition into a different context, for example by taking into consideration the social situation, rather than the historical facts. While it is not my intention to criticize such a methodology of analysis, I would like to stress that the method adopted here does not aim 
to provide a modernization of sor Juana's writings, nor to show that everything that has been written following the gamut of what we know very generically as post-structuralism has to be considered as outdated. Rather, and following what Jonathan Culler (1975, p. 161) explains in Structuralist Poetics, I would like to foreground the possibility to give to the literary text what we can imagine as its "freedom of speech" and the possibility of recontextualization.

The text that we will analyze in this chapter is an answer that sor Juana writes in response to a poem dedicated to her by an anonymous gentleman from Peru. During her lifetime, sor Juana wrote several such answers on various different topics. Her most famous reply is La Respuesta a sor Filotea de la Cruz (The Answer; 1700). Literary, and particularly feminist, criticism (Kirk, 2016; Lavrin, 1983; Ludmer, 1984; Merrim, 1991; Schons 1926; Yugar, 2014) takes La Respuesta a sor Filotea as the pivotal text of sor Juana's oeuvre. The text is taken to exemplify her insights into gender politics, because in many passages of this text - among many interesting insights into other issues related to the freedom of women to write and study-sor Juana demonstrates that there are no actual reasons to justify the exclusion of women from academic and/or scientific knowledge. In this chapter, I present a reading of sor Juana's work-specifically regarding the theme of sex - taking another composition as central to her work, namely: Respondiendo a un Caballero del Perú (Replying to a Gentleman from Peru; 1692). By considering the answer to the gentleman from Peru as central, the perspective on the theme of sex radically changes, allowing me to cast new light on sor Juana's contribution to the contemporary debate on the subject.

Indeed, the traditional reading of sex, centered on La Respuesta a sor Filotea de la Cruz, forces the reader to impose upon sor Juana a fracture between what she writes 
about sex and what she writes as a female author. This fracture marks the distance between an intellectual approach to sex in which the topic of sex is discussed without attributing a specific gender or sex to the author, and a social and political expression of sexuality in which a sex (in this case, female) has already been assigned to the author. Importantly, I am not concerned here with analyzing this fracture itself, or indeed reconciling its edges. Nevertheless, it is possible to reduce its width-between the intellectual approach to sex, and the social and political expression of sexuality. Using sor Juana's wider oeuvre, it is possible to question the expression of sex in La Respuesta. In this way, I read La Respuesta specifically in the context of women's rights, not necessarily as something written by a "woman", but rather, according to what she writes in Respondiendo a un Caballero del Perú, as something written by a female subject who maintains an identification with a particular sex that is constantly being questioned.

It is particularly interesting to turn to the illustrative poem Respondiendo a un caballero del Perú because it clearly shows that in sor Juana's thought, it is impossible to reduce "sex" to the specific and contingent biological condition of "being a woman". Indeed, as Margo Glantz (2006) argues, the fact that sor Juana was a woman generates interest in her figure. In Glantz's (2006) essay “Sor Juana ¿hagiografía o autobiografía?” (“Sor Juana: Hagiography or Autobiography”), sor Juana's sex is framed with these words:

Cualquiera que sea la metodología empleada — casi siempre interesante—, salta a la vista la enorme (y a veces hasta malsana) curiosidad que el personaje despierta: en los 
varones porque fue mujer; en las mujeres, porque es posible convertirla en una de las primeras feministas y erigirla como modelo (Glantz, 2006, p. 223 $)^{21}$

In this passage, Margo Glantz underlines that the first thing that attracts literary criticism, is sor Juana's sex. Since sor Juana is considered a woman, the term "sex" is simply presented as a condition, either social or biological, and the sorjuanist criticism only has to analyze the effects that became manifest in sor Juana's life and writings as a result of this condition. This tendency of literary criticism, and feminist literary criticism in particular, ${ }^{22}$ to assign a sex or gender to a writer is a consequence of the decision to answer the question: "What is his/her sex/gender?" This question implies, not only the identification of a subject with an essential, general category, but also the ontological determination of the subject's sex/gender. As a consequence, the identity of a given subject becomes subsumed within a general category (for example, man or woman, or male and female). This ontological perspective on "sex", in which "sex" is one of the possible answers to the question "What are you?", is precisely what sor Juana criticizes in her oeuvre and in particular in the poem entitled Respondiendo a un caballero del Perú. The aim of this chapter, in line with the general aim of this dissertation, is to offer an alternative interpretation of some of the passages sor Juana dedicates to sex generally, and the determination of her own sex in particular. This interpretation has to be

21 "Whichever methodology is adopted - most of the time a very interesting one-the enormous (sometimes unhealthy) curiosity awoken by the personage is patent: in men because she was a woman; in women because it is possible to convert her into one of the early feminists and set her up as a role model" (translation mine).

${ }^{22}$ In 2002, Toril Moi published the second edition of Sexual/Textual Politics: Feminist Literary Theory, now a classic of feminist literary theory. In the afterword, she explains in greater depth why she separates feminist criticism from feminist theory, and why she argues in favor of theory (Moi, 2002, p. 175). The reason why Moi is inclined toward theory is that by making such a distinction, she associates feminist criticism with mainly Anglo-American authors and scholars who demonstrate a strong essentialist attitude. With such an expression of feminist theory, she is referencing the feminism informed by Derridean deconstructionism and post-structuralism. Here, I subscribe to Moi's definitions by using the expression "feminist literary criticism". 
understood as an alternative to the ordinary definition of "sex" as a biological condition, because it changes the perspective from which it is possible to look toward the concept of "sex". In other words, we may accept that it is no longer possible to conflate author/subject and author/sex, particularly in light of what is stated in the preceding chapter. That is to say, because "the author" denies their own neutral and autonomous status, pluralizing and differentiating the sense and the voices of the subject, it is no longer possible to automatically associate them with one sex or one gender, understood in their general sense, instead making sex and subject the expression of something that is singular in its difference. In this way, the sense of the absolute authority of the author is reduced to just another voice among a myriad others - a voice not easily identified with any fixed, predetermined sex. Indeed, the term "sex" changes accordingly with the changing sense of a subject that can no longer be understood as universal, neutral, or autonomous.

For this reason, in sor Juana's works, the terms "sex" and "gender" require a new, different reading. In her work, I seek those moments in which "sex" is no longer identified with an "essence" established or depending on the "nature" of the subject. In fact, the dismantling of the absolute position of the universal subject creates a de-universalization of the concepts of "sex" and "gender", specifically because they are not rooted outside of the subject, but rather depend upon it. As a result of this subversion of the common interpretation of the terms "subject", "sex", and "gender", we cannot proceed following a logic based on similarities, identities, or essential determinations. Indeed, nor can we answer the ontological question "What is ...?", because the use of the verb to be reinforces an irrevocable status of presence that is, in fact, the main target of the operation of deconstruction ante litteram operated by sor Juana. In order to better sustain this analysis of the peculiar sense of "sex" adopted by sor Juana, I now turn toward one of 
Jean-Luc Nancy's (2017) most recent essays, entitled Sexistence. This work by Nancy will be useful when attempting to understand both how sor Juana uses the word "sex", and how she plays with its meanings.

Nancy's (2017) concept of sexistence provides the possibility to simultaneously express the "act" of existence and the "act" of sex. In this work, Nancy returns to an issue that he already approached in another crucial essay, $L$ ' "il y a" du rapport sexuel (Nancy, 2001), in which he challenges the Lacanian affirmation "il n'y a pas de rapport sexuel" (Lacan, 2006, p. 226). Nancy (2001) suggests that Lacan, by affirming that sex does not belong to the sphere of Being, at the same time refuses its existence. He fundamentally agrees with Lacan that sex does not belong to the sphere of Being, but rather revendicates its existence (il $y a$ ), highlighting the corporeal dimension of sexuality and the sexual relationship with otherness (Nancy, 2001).

In Sexistence rests the key to understanding that, for sor Juana, sex/gender in its current configuration fails to work properly, because for sor Juana, sex is not a natural and biological given, and gender is not a cultural and social construct. In fact, she transforms the idea of "sex" into an act, as Nancy (2017) proposes in Sexistence, while, instead of a social construct, the idea of "gender" (género) references a "homogeneous group" (from the Latin sense of the etymon genus). The essay by Nancy is helpful because at the core of his argument, Nancy critiques "sex" as a biological given — a critique that sor Juana, as we will see in the poem Respondiendo a un caballero del Perú, also proposes when she refutes being considered a woman, since she is not acting (sexually) like a woman.

The above permits us to reinterpret the common pairing of sex/gender into the unusual pairing of sex/genre, in which "genre" means "homogeneous group". In this way, 
the singularity of "sex" is counterposed to the homogeneity and universality of "genre", and the word "sex" can also indicate something different in its singularity. By subverting the position and meaning of the term "sex", it can longer be paired only with the word "gender". In fact, "sex/gender" functions only as a derivation of the pair "nature/culture". The pairing of "sex/genre", on the contrary, functions more in the sense of "singular/universal". In "sex/genre", the term "sex" represents singular rather than universal aspects. Operationalizing this conceptual inversion of the word "sex" from its classic meaning, introducing instead the concept of "sex/genre", it becomes possible to view "sex" in "sex/genre" as fluid and changeable, while "genre" assumes a predetermined and static position.

This subversion, as we will see at the end of the chapter, undermines the principle of "non-contradiction" because it proposes to introduce a subjectivity that does not need an identification- "what I am" and "what I am not"- to function. Introducing into the spectrum of possibilities the body that "resists" being identified with a sex, sor Juana challenges the binary logic of "diversity", instead pointing toward an unreplaceable, free, and fundamentally different subjectivity. In light of the foregoing, this chapter focuses on the analysis of the poem Respondiendo a un Caballero del Perú, adopting a deconstructionist perspective on the definition (and self-definition) of sor Juana's sex.

\section{Moving the Attention from La Respuesta to Respondiendo a un caballero del Perú}

Respondiendo a un caballero del Perú, que le envió unos barros diciéndola que se volviese hombre (which translates as Replying to a gentleman from Peru who had sent her some small clay vessels telling her she should become a man) is a poem that appeared for the first time in the 1692 edition (second volume) of works by sor Juana Inés de la 
Cruz, entitled: Segundo Volumen de las Obras de sor Juana Inés de la Cruz, monja profesa en el monasterio del señor San Gerónimo de la Ciudad de México, dedicado por su misma autora ad. Juan de Orue y Arbieto caballero de la orden de Santiago (Second volume of the oeuvre by sor Juana Inés de la Cruz, professed nun in the cloister of San Géronimo in México City, dedicated by her own author to Juan de Orue y Arbieto, knight of the Santiago order). The volume was printed in Sevilla by Tomás López de Haro, and opens with a letter by sor Juana known as the Carta Atenagórica, the title of which in the original edition was Crisis sobre un sermón. This letter constituted a watershed in sor Juana's life because, in spite of being a woman, she dared to write about theology. $L a$ Respuesta a sor Filotea - briefly alluded to in the introduction of this chapter-is the text sor Juana wrote to apologize for writing Crisis sobre un sermón. Before entering into the analysis of the poem Respondiendo a un caballero del Perú, I need to refer to La Respuesta because for a long time — at least until $1980^{23}$ — it represented the primary (and only) source of reliable information about sor Juana's life. La Respuesta a sor Filotea and Crisis sobre un sermón share a strong connection since in La Respuesta, sor Juana had to issue an official apology for the publication of Crisis sobre un sermón for the manner in which it critiqued a sermon written by the famous Portuguese Jesuit Antonio Vieira.

La Respuesta is the answer written by sor Juana to a letter received by the bishop of Puebla, Manuel Fernández de Santa Cruz, in 1691. La respuesta a sor Filotea appeared in the third volume of sor Juana's works_Fama $y$ obras Posthumas, published

\footnotetext{
${ }^{23}$ In 1980, Aureliano Tapia Méndez discovered a letter known as "Carta de Monterrey" or "Autodefensa espiritual", then attributed to sor Juana. The letter addressed to Padre Antonio Núñez de Miranda, confessor of sor Juana, contains a lot of information about sor Juana's life (Tapia Méndez, 1981).
} 
posthumously in 1700, and translated into English as The Answer. ${ }^{24}$ The answer takes the form of an apology for writing Crisis sobre un sermón, but is also a strong critique of the power structures in colonial New Spain.

Establishing Crisis sobre un sermón and La Respuesta respectively as points of departure and arrival with regard to the development of the discourse about sex and gender in sor Juana Inés de la Cruz's oeuvre, we can imagine the texts being connected by a common narrative thread, not least as La Respuesta would not have been written had sor Juana not criticized a sermon written by a man. In other words, Crisis sobre un sermón represents both the beginning and the cause of the definitive clash between sor Juana and the patriarchal and misogynist society in which she lived - a society that did not tolerate a woman arguing with a Catholic man, even if her life was devoted to God and her argument solid and aligned with the orthodoxy. La respuesta a sor Filotea is the extended and brilliant text in which sor Juana is called upon by the bishop of Puebla to furnish an explanation for not serving the Church "properly" by observing her duties as a nun. Of course, in La Respuesta, sor Juana does not betray her enigmatic and polysemic style. No matter if the argument is based on theological grounds, able to dismantle the very roots of the accusation she received, or if it is based on a more common claim for equality between the sexes, the core of the question remains the same: There are no reasons why a woman cannot have the same intellectual life as a man.

Now that the two extremes of this latest evolution of the events related to sex and gender in sor Juana's life have been firmly established, there necessarily needs to be some mention of those poems that do not fit within this debate. Such works assume a position

\footnotetext{
${ }^{24}$ There are many translations of La Respuesta. The most relevant are the translation of 1982 by Margaret Sayers Peden; the translation of 1988 by Alan Trueblood; and the translation by Amanda Powell and Electa Arenal, published in 1994.
} 
that cannot be reconciled with a debate between those who believe women are not entitled to write and study at an academic level, and those who clearly feel that this is unfair and based on centuries-old misconceptions. From the perspective of feminist criticism, this dialogue, comprising requests and their corresponding answers, might seem closed and self-explanatory. Nonetheless, in my opinion, the poem Respondiendo a un caballero del Perú shakes the fundamental principle of this debate and places a question mark over it: Is sor Juana endorsing the equality fight simply because she is a woman herself? Instead of seeking to answer this question posed by La Respuesta - in which it is obvious that sor Juana is proclaiming a woman's right to study-I decided to shift my attention to the poem in which sor Juana offers a less explicit answer about what should be perceived as her "proper" sex. In order to arrive at a different answer, I consider it prudent to redirect our attention and find a possible connection with the narrative thread emanating from Crisis sobre un sermón to La Respuesta. From my perspective, and from a deconstructionist point of view, it is impossible to ignore sor Juana's sex, however, I will consider it always open to question. A significant consequence of adopting this perspective is the necessity to subvert traditional modes of thinking regarding the autobiographical account as always being the bearer of a greater level of historical truth.

Before entering into the reading of the poem Respondiendo a un Caballero del Perú, I need to state clearly and firmly that the well-known Some Obscure Points in the Life of Sor Juana Inés de la Cruz (Schons, 1926, p. 141), which inaugurated a proper canon of criticism of sor Juana's work, will remain outside the scope of this thesis, since I am not concerned here with the demonstration of any biographical fact. On the contrary, and probably resorting to a more baroque perspective on "reality", each obscure, uncertain, erratic, and ambiguous element provides to this reading a new fertile path for 
a possible different interpretation that allows the literary text to live beyond its own historical, social, and contextual limits. In doing this, the reading of Respondiendo a un caballero del Perú will not supply a direct answer to the question "Was sor Juana a woman?" even if, at first sight, it seems to supply precisely only the answer to this question. This is because, at the explicit and superficial level of discourse, the reply to the gentleman from Peru can lead the reader to the conclusion that sor Juana has a complex relationship with her sex — pertaining both to her own sex and the female gender.

\section{Pues no soy mujer: The Denial of Belonging in Respondiendo a un Caballero del} Perú

It is time to unveil the content of this mysterious answer that sor Juana offers to the gentleman from Peru. I would like to present and comment upon the text, first reading and making the complex baroque matter more suitable for a modern reader. Subsequently, I will provide some marginal annotations useful to understand the poem, and finally, I will proceed with a deeper analysis of sor Juana's words. It will not be necessary to read the whole composition, focusing instead on those passages coherent with, and connected to, the topic of this chapter.

It is no coincidence that I decided to use a poem that performs the role of an answer. Following what has been established in the first chapter, this answer in verse represents another "double slash" to the metaphysical subject sor Juana criticizes in $E l$ Neptuno Alegórico. Firstly, in such an answer there is no place for a subject that embodies the first and leading voice, or indeed, for a subject that posits and answers its own question. Quite the contrary, an answer opens a space for a subject that speaks after, that is second to, the voice of the question. Secondly, the use of a subject that behaves like a 
subsequent voice in a poem also represents a slash against traditional lyrical poetry marked by the "I". In fact, sor Juana is able to write in a manner that is personal, while simultaneously, the "I" is linguistically and grammatically forced out of the active position of being the "I" who posits the question, since that same "I" assumes the position (neither active nor passive) of answering as a subjectivity more than as a subject. In order to deconstruct the poem Respondiendo a un caballero del Perú-that is to say, in a Derridean sense of the action, shaking the poem, undermining its logic, and provoking a different textual outcome (Derrida, 2013, p. 34) —it will be useful to proceed step-bystep, underlining the crucial passages of the text, and starting from a traditional close reading of the poem.

The first element that deserves a comment is the epigraph of the poem. Without engaging in an overly long explanation of its philological aspects, along with the first edition of 1692, the text was edited by Martha Lilia Tenorio in 2018 . However, the earlier edition by Antonio Alatorre (2009) will also be considered, as this was used by Tenorio herself. In addition, following the history of the modern editions, it is not possible to exclude Alfonso Méndez Plancarte’s 1951 edition.

The poem written by the gentleman from Peru is now lost, as is the identity of the gentleman, although most probably he was Sebastián Navarrete (Cruz, 2018, p. 119). What we can say with certainty, reading sor Juana's reply, is that the gentleman from Peru sent sor Juana some "clay vessels, telling her she should become a man" (Trueblood, 1988, p. 27). The sending of the clay vessels can be related to the invitation to become a man, making reference to some of the collateral effects of the popular habit among women in the Spanish Empire during the early modern era of eating clay in order to inhibit the menstrual cycle, and to attain a paler complexion. However, perhaps more worthy of 
attention is the suggestion that sor Juana should become a man. The resulting question is of course: Should sor Juana be a man, instead of being what?

The first 85 verses in sor Juana's reply are written as a classic praise of the gentleman, characterized by such hyperbole that it is relatively easy to conclude that sor Juana is adopting this exaggerated style in order to obtain exactly the opposite effect: to ridicule the gentleman. Starting from verse 85 , the poem focuses on the question of becoming a man:

$$
\begin{aligned}
& \text { Y en el consejo que dais, } \\
& \text { yo os prometo recibirle } \\
& \text { y hacerme fuerza, aunque juzgo } \\
& \text { que no hay fuerzas que entarquinen: }
\end{aligned}
$$$$
\text { (Cruz, 2018, p. 120, lines 85-88) }
$$

After a very long introduction comprised only of jocular praise of the Peruvian gentleman, these first four verses allude to the suggestion (consejo $)^{25}$ received by the gentleman. Sor Juana promises to follow the advice [recibir el consejo] and forces herself to become a man (hacerme fuerza), even if in her opinion, there does not exist anything that could turn her into a man. The verb "entarquinen" is, in my opinion, semantically peculiar. This is the first example of what I perceive from a deconstructionist perspective as resistant to any easy, direct translation. In fact, the verb entarquinar has its own history and is polysemic. An examination of its historical use reveals the diachronic evolution of the word, while the polysemy represents a synchronic multiplicity in its meaning. The problem is that there are no clues here to detect where the diachronic axis intersects the

\footnotetext{
${ }^{25}$ I use round brackets when I quote from the Spanish text to orient the reader into the poem, and square brackets to provide the Spanish translation from English when the text in brackets does not literally corresponds to the text of the poem.
} 
synchronic axis - an intersection that would declare the meaning of entarquinar, indicating a unique corresponding meaning. From my particular and singular position, which is grounded in a deconstructionist method of reading, the solution to this problem is to dismantle the problem itself. I suggest that the correspondence between the "when" (when the term is used) and the "what" (what the term means) represents a problem only if we approach the reading using a Cartesian system of univocal, linear, and closed correspondences. The deconstructionist approach, however, opens and liberates each axes, which are now free to move and create each time a new possible correspondencethat is to say, a new possible meaning. This method will guide this close reading and my approximation of sor Juana's texts.

With regard to the etymology of the verb entarquinar, the Diccionario de Autoridades (1732) suggests that, formed by the preposition en- and the noun tarquin, it means to fill something with tarquin (mud). Of course, we must acknowledge here that this is by no means the only interpretation of the word. As Alfonso Méndez Plancarte (1951) and Martha Lilia Tenorio (2018) observe, entarquinar includes the name of Lucius Tarquinius Superbus, the 6th king of Rome and the man who raped Lucretia in Titus Livius' account of the history of Rome entitled $A b$ Urbe Condita. Leaving aside the history of Lucretia, Méndez Plancarte and Tenorio suggest a different sense of the verb in which entarquinar means to turn someone - in this case, sor Juana —into a virile man like Tarquinius (Cruz, 1951, p. 433; Cruz, 2018, p. 120).

What do we have to do as readers? Do we have to choose only one meaning? Or can we accept both? I suggest here that we accept both meanings. In the first case, the verb entarquinar means to make something dirty with mud. In the second, it means to transform someone into a "virile" rapist. The interplay between the two is interesting: Sor 
Juana receives clay vessels from the gentleman, probably as an explicit invitation to eat the clay from the vessels and in this way to dirty herself with mud (tarquín). However, at the same time, she receives an invitation to turn herself into a man, or in other words, a Tarquinius. Facing at once these two invitations, there is no more appropriate verb than entarquinar. Moreover, Tarquinius forced himself upon Lucretia (becoming the dirty part of the history), and sor Juana claims that she tried to force herself to become a man, while asserting that there do not exist forces (fuerzas) able to "entarquinar" someone. In forcing herself to become a man, sor Juana recognizes that an act of violence occurs and that like Tarquinius, she would become the dirty part of the history.

Proceeding at a slow pace, the next verses exemplify some other aspects of the impossibility of turning herself into a man:

$$
\begin{aligned}
& \text { porque acá Sálmacis falta, } \\
& \text { en cuyos cristales dicen } \\
& \text { que hay no sé qué virtud de } \\
& \text { dar alientos varoniles. }
\end{aligned}
$$

(Cruz, 2018, p. 121, lines 89-92)

In order to understand these verses, it is first necessary to introduce the figure of Salmacis. This reference to the Metamorphoses by Ovid introduces the interesting figure of the hermaphrodite into a poem written as a reply to a question about sex. However, hermaphroditism is not treated here as some superficial means to avoid answering the question. In the account of Salmacis, we find an acute interpretation of the myth that, instead of providing an answer, complicates the question because it introduces the issue of sexual violence. Again, I need to approach this reference from a deconstructionist 
perspective. In other words, I am not interested in the "origin" of this quote, but in the implications this quote carries for the text.

Salmacis is the nymph who, in Ovid's Metamorphoses (2008, pp. 83-85), falls in love with Hermaphroditus, ${ }^{26}$ the son of Hermes and Aphrodite. When Salmacis succeeds in binding Hermaphroditus' body with her arms, she prays that the Gods will make their bond eternal. Indeed, the Gods fulfil Salmacis' wish, and the two bodies merge, creating a being that contains both sexes: female and male. The crystals (cristales) sor Juana mentions are the crystalline waters of the spring where the nymph lives in the Greek region of Caria. This element is fundamental, because in the moment when the body of Salmacis merged with Hermaphroditus' body, Hermaphroditus prays that the Gods will avenge his humiliation. As a consequence, Salmacis' spring was cursed and its waters became a poison which, according to the Ovidian tale, would effeminate whoever entered or touched the waters as a man. This remark can be interpreted as a mistake by sor Juana, since she claims that Salmacis' fountain should give her a manly breath (aliento varonil). Moreover, the power of the water is considered not to be an inherent virtue (virtud) of the spring, but rather the result of rape and subsequent damnation. Even if we accept the idea that sor Juana falsely interpreted Ovid's tale, it is evident that there is a very interesting link between the first quatrain (examined previously) and this quatrain, namely, the sexual violence perpetrated by Tarquinius and Salmacis.

When the interpretation is based, not on the actual existence of the possibility to be transformed into a man, but on two examples of abuse, the incorrect description of the

\footnotetext{
${ }^{26}$ For more on the figure of Hermaphroditus in sor Juana's poem, see the essay by Margo Glantz, "El cuerpo inscrito y el texto escrito o la desnudez como naufragio: Álvar Núñez Cabeza de Vaca, published in 2006 in the edition of the complete works by Margo Glantz (2006, p. 107); and the essay by Stephanie Merrim, "Toward a Feminist Reading of Sor Juana Inés de la Cruz: Past, Present, and Future Directions in Sor Juana Criticism, published in 1991 in the collection of essays Feminist Perspectives on Sor Juana Inés de la Cruz (Merrim, 1991, p. 22).
} 
power of Salmacis' spring becomes but a minor problem. Yet the presence of the violence supports the idea that sor Juana knew Ovid's tale, since in Metamorphoses, the figure of Salmacis is firmly presented as the rapist of Hermaphroditus. Furthermore, the Ovidian Salmacis is depicted as a peculiar nymph, uninterested in hunting as a creature bound with the essence of the Goddess of the Hunt, Diana, should be. In fact, Salmacis is brought back as a particularly effeminate nymph, in stark contrast with the exceptional virility of Tarquinius. The point then, is to have two figures: a man and a woman, able to represent, not only sex — being man or woman — but sex as an act. Whether a woman or a man, a dichotomous view of sex now rests on the two facets of the sexual act: On the one hand, we have sexual violence - or, in other words, the antithesis of sex-while on the other hand, there is sex intended as a consensual act between two people. Sor Juana places any distinction between female and male sex on a secondary level, the primary focus slowly moving toward the conflation of the meanings of "sex"-although the term never appears explicitly in the verses, but rather is implied, hidden beneath metaphors, allusions, or synecdoches. The latter use of words - as figurative terms for sex-is particularly interesting, since we will see how terms such as woman (mujer) and wife stand for the multiple meanings of the term "sex". As we have already seen, it is often a single word or expression that, in sor Juana's conceptos, carry two (or more) senses and possible interpretations.

Turning now to the third quatrain. The stanza contains the first part of the reply of sor Juana. It functions by way of an introduction and offers the key terms of our author's problem and why she cannot change her sex:

Yo no entiendo de esas cosas

sólo sé que aquí me vine porque, si es que soy mujer, 
ninguno lo verifique.

(Cruz, 2018, p. 121, lines 93-96)

Sor Juana affirms that she is not acquainted with "these things" (esas cosas) and that she does not understand them (no entiendo de esas cosas). She only knows that she decides to live here in a cloister (solo sé que aquí me vine) because, in the eventual occurrence that she can define herself as a woman (si es que soy mujer)—or, more literally, if she is a woman-nobody can verify her sex (ninguno lo verifique). The verses of these quatrains are undoubtably impactful and enlightening, especially regarding one of the most frequently recurring (currently unanswered) questions about the life of sor Juana remains why she entered a cloister when she could have enjoyed a pleasant life at court (Schons, 1926, p. 142). This quatrain provides a clear answer to that question, yet doubt remains throughout the history of criticism about sor Juana's works of exactly why this was the case. Reading the verses again, in light of the preceding quatrains, it is evident that there is something more here than a simple biographic annotation. It is exactly this deeper meaning that interests me, and this I need in order to proceed with my particular purpose.

To quickly recap, the fundamental question driving this chapter hinges on why sor Juana does not reply to the Peruvian gentleman saying that she cannot be a man for the simple and self-evident reason that she was born a woman and, despite all the difficulties a woman can have in living in such a sexist and misogynist era, sex is something unchangeable and pre-determined by objective conditions. However, sor Juana's answer is far more complex than this. First of all, she admits that she does not understand "these things" (esas cosas) - that is to say, she understands neither what sex should be (the man/woman dichotomy), nor how it should be verified. If indeed sex is something that 
needs to be verified, in the last two verses of the quatrain there is both a clear anticipation of the discursive limits of sex as discussed by Judith Butler (1992) in Bodies That Matter, and also a reference to another kind of limit, namely that by entering the cloister, sor Juana renounces sex as an act.

Reviewing sor Juana's journey thus far, it is possible to see how the impossibility of changing sex hints at the ontological and universal impossibility of sex itself. In addition, it is also impossible to change sex if this sex is not verifiable. The first two quatrains of the verses presented above place female and male sex on the same level: In perpetrating a rape, both sexes received a blemish that turned sex, not only into a category (or in other words, a genre), but also into something that is performative in the Austinian pragmatic sense of the term (Austin,1962). Consequently, the quatrain opens by asking what sor Juana intends when she states that nobody can verify if she is a woman-a question that will find its answer along the next three quatrains:

$$
\begin{aligned}
& \text { Y también sé que, en latín, } \\
& \text { sólo a las casadas dicen } \\
& \text { uxor, o mujer, y que } \\
& \text { es común de dos lo virgen, } \\
& \text { (Cruz, 2018, p. 121, lines 97-100) }
\end{aligned}
$$

Using a peculiar rhetorical strategy, sor Juana places the arguments in support of her reply, before the reply itself. For the second time, the verb that plays a major role in the verses is the verb "to know". In the preceding quatrain, we saw the same verb appearing in the second verse after the striking expression "I do not understand" (Yo no entiendo), where it is possible to read "I only know" (sólo sé que). Here we discover that sor Juana knows something more (Y también yo sé), which is connected by the anaphoric 
sólo at the beginning of the second verse of the quatrains. She knows that the term to indicate women in Latin is the same term used to address wives: uxor (en latín, / sólo a las casadas dicen uxor). In doing this, what a woman is and what a woman does, coexist under the same term (uxor or mujer in Spanish), thus creating a peculiar equation that sor Juana complicates even further. Indeed, the last verse (es común de dos lo virgen) affirms that both share the trait of virginity, leaving a shadow on the actual meaning and reference of the term "both" (dos). According to Martha Lilia Tenorio (Cruz, 2018, p. 121), the trait of virginity is common to "both" men and women, since both of them are defined as "virgins" if they have never had sexual intercourse. Accepting this interpretation, a virgin can be either a male virgin or a female virgin — or better still, a sexless virgin, making reference to, and playing with, the plural sense of the expression "a virgin has no sex". Within this expression it is possible resolve the possibility of "having sex" and "having $a$ sex".

The next quatrain offers the first half of the reply:

$$
\begin{aligned}
& \text { conque a mí no es bien mirado } \\
& \text { que como a mujer me miren, } \\
& \text { pues no soy mujer que a alguno } \\
& \text { de mujer pueda servirle, } \\
& \text { (Cruz, 2018, p. 121, lines 101-104) }
\end{aligned}
$$

By virtue of her virginity, sor Juana claims, it is not possible to look at her as a woman and, as a consequence, she is not a woman (pues no soy mujer), since she cannot be useful as a woman to anyone.

The following quatrain contains the second half of the reply:

$$
\text { y sólo sé que mi cuerpo, }
$$


sin que a uno u otro se incline,

es neutro, o abstracto, cuanto

sólo el alma deposite.

(Cruz, 2018, p. 121, lines 105-108)

The first line anaphorically repeats the same "I only know" (y sólo sé), confirming that sor Juana actually knows more about sex than she admits. However, another important element is also introduced here. Sor Juana begins to make allusions to her own body ( $y$ sólo sé que mi cuerpo). However, contrary to what many scholars claim (Merrim, 1991; Paz, 1982; Pfandl, 1963), she describes her body not as in conflict with itself, nor as an hermaphrodite, but rather as neuter or abstract (neutro, o abstracto). We need to pay attention to the use of the adjective "abstract", since abstracto, according to the Diccionario de Autoridades (1726), has an unusual and very interesting meaning in $17^{\text {th }}$ and $18^{\text {th }}$-century Spanish: At that time, "abstract" meant "out of the self", or "separated from the subject". As we already know from the first chapter of this dissertation, the subject can be thought of as deprived of its substance. It is easier to think about a body that lacks substance, because it is neuter (neutro) or, in other words, it is neither female nor male, active nor passive and, according to its third possible meaning, neither neuter nor neutral. Why, one may ask, does sor Juana have a body if this body is useless? The reason is explained in the last verse: Sor Juana's body is useful only as a repository for her soul. ${ }^{27}$

\footnotetext{
${ }^{27}$ Margo Glantz dedicates a passage about this quatrain in her essay about María de Zayas, entitled "El entorno de Sor Juana" , which appears in the first volume of the complete works by Margo Glantz, Obras reunidas 1. Ensayos sobre literatura colonial (Glantz, 2006). I quote from this edition the passage about androgyny in sor Juana: "La neutralidad o la abstracción del cuerpo forman parte de una codificación cultural que contrasta y convive flagrantemente con la ponderosa presencia del cuerpo tal y como era concebido desde la antigüedad clásica. [...] Polarizaciones extremas edificadas sobre el supuesto de que la mujer es inferior al hombre y no sólo eso, un hombre mutilado, y por tanto incompleto, incapaz por ello de
} 
The last quatrain concludes the reply and, once more, sor Juana shows that she is not interested in accepting the invitation of the gentleman (after demonstrating that the gentleman took for granted too many things; that the invitation itself is meaningless; and that is not applicable to her situation) because she kindly refuses to be engaged in any further conversation:

\author{
Y dejando esta cuestión \\ para que otros la ventilen, \\ porque en lo que es bien que ignore, \\ no es razón que sutilice,
}

(Cruz, 2018, pp. 121-22, lines 109-112)

Leaving this issue aside (dejando esta cuestión), sor Juana concludes her reply by stating that it is pointless to discuss this argument in further detail, because it is better for her to ignore everything about it. This "it" should not automatically be thought of as the question of sex itself, but rather could be read as the question of changing her sex. Moreover, in writing that there are no reasons to go into more detail (no es razón que sutilice), sor Juana declares at the same time that, as a matter of fact, she is absolutely able to go into

jamás igualarlo. La tradición eclesiástica decreta una ley divina para justificar la superioridad masculina. Zayas y sor Juana se defienden contra esos decretos afirmando la neutralidad del alma. [...] El entendimiento es andrógino, se aloja en el alma, tópico muy utilizado en la época, idea favorecida muchas veces por las mujeres que descollaban; si una mujer poseía un entendimiento excepcional, la argumentación que agigantaba su singularidad recurría a los estereotipos clásicos de la misoginia" (Glantz, 2006, p. 203). "Neutrality or the abstraction of body are part of a cultural codification that is in contrast, but at the same time coexists, in flagrante with the powerful presence of body as it was conceived during the Classical times. $[\cdots]$ Extreme polarizations built upon the assumption that the woman is inferior to the man and not only this, but also that it was a mutilated body, incomplete, and for this reason unable to equal the male body. The ecclesiastical tradition decreets a divine law to justify male supremacy. Zayas and sor Juana defend themselves against these decrees affirming the neutrality of the soul. [...] The mind (entendimiento) is androgynous, stays in the soul, a very common topic during that time, an idea often supported by outstanding women; if a woman was in possess of an exceptional mind, the arguments that exaggerated her uniqueness turned to the classical stereotypes of misogyny" (translation mine). 
more detail—much like Herman Melville's (2002, p. 10) Bartleby the Scrivener: A Story of Wall-Street, she simply "would prefer not to".

Like the introduction, lines 113 to 140 , the final section of the poem, are not directly relatable to the main argument of this chapter. Indeed, in these lines sor Juana develops a tense dialogue with the Peruvian gentleman, in which she lets the reader know that he is in New Spain by virtue of his being ostracized from Peru and, almost threatening him, she writes ironic words to welcome him to New Spain.

This close reading highlights some keywords and passages that will be crucial to the next section, which is dedicated to establishing a dialogue between Sexistence and this peculiar poem. First of all, the whole reply is based on the assumption that it is impossible for sor Juana to transform herself into a man, because she is neither woman nor man. Secondly, it is also important to bear in mind that, while sor Juana undermines essentialist ideas of sex, at the same time she claims that she is not a woman because she does not act (sexually) like a woman should. Thirdly, she makes a distinction between "virgin" and "woman", citing the former's validity for both men and women. Finally, she writes that her body has no sex because it feels no attraction for anyone, adding that it is in fact neuter, neutral, and abstract.

\section{4. "She Should Become a Man": Sex as a Bodily Act in sor Juana and Jean-Luc}

\section{Nancy}

The centrality of Respondiendo a un Caballero del Perú resides in the long title under which it appeared in its first edition. The title has been translated into English as "Replying to a gentleman from Peru who had sent her some small clay vessels, telling her she should become a man" (Trueblood, 1988, p. 27). It is obvious from the title that the 
intention of the gentleman from Peru is for sor Juana to change her sex. However, as we read in sor Juana's words, the affirmation "her sex" already contains a fundamental question, namely: Which sex? The answer provided by sor Juana is acute and complex, offering a milestone along the history of the theoretical investigation of the concept of sex.

The reason why Respondiendo a un caballero del Perú is able to undermine all of our assumptions about how sor Juana feels under the misogynistic and aggressive regime of the time is that, in this poem, we find an intriguing theoretical shift-a step toward the detachment of the idea of sex from the idea of gender. If adhering to a strict definition of sex and gender, it is evident that there is little room left to discuss the moments in which sor Juana criticizes or provokes her supposed belonging to a specific sex, detaching it from the idea of gender and at the same time from the idea of a biological status, or sociocultural construct. Indeed, as discussed earlier, the line that connects Crisis sobre un sermón and La Respuesta a sor Filotea does not easily intersect with any critique of sex, but only a critique of gender roles or gender-based discrimination. At best, any critique of what we can call "sex" in La Respuesta can be realized only by taking into consideration the "discursive limits of sex" as posited by Judith Butler: the subversion of the role of sex and gender in the classic "reading" of bodily matters and identities. Here, I refer in particular to Gender Trouble: Feminism and the Subversion of Identity (1990), Bodies That Matter: On the Discursive Limits of Sex (1993), and Undoing Gender (2004). In these three texts, Butler operationalizes a revolution of the concepts of gender and sex, and in particular of a concept of gender that is not considered as a noun, but as "a doing" (Butler, 1990, p. 33). In other words, traditionally, sex is subjugated by a subjective 
condition in which a strong Lacanian mindset leaves no room for anyone to provide a radical negative answer to the question "What is your sex?".

In Sexistence, as stated in the introduction to this chapter, Nancy (2017) considers sex as an act, and therefore as something that does exist - also if it does not belong to the sphere of Being, thus challenging the Lacanian statement "il n'y a pas de rapport sexuel":

Un excès, une excédance ou transcendance. Une poussée d'être qui n'a aucune autre sens (ni raison, ni cause, ni fin) que d'être poussée - d'être en tant que poussée et d'être poussée par... son propre excès. Qui ne lui est donc pas "propre” puisqu'il est exclu d'atribuer une propriété quelconque à "être". En deçà de toute propriété ça arrive et ça existe. Ça se donne puisque ça n'est pas donné, ça se désire sans être désiré par quiconque. C'est pourquoi la chose, le réel est à réaliser. (Nancy, 2017, p. 90)

According to Nancy, sex is a ça [it]: something that is indefinite- that is to say, something that cannot be defined by a "what is" in the sphere of Being, but that, nonetheless, exists. This ça is not a thing or a status (i.e. a biological reality), but rather something that refuses to reply to the question "What is?". For this reason, it exists beyond the sphere of definition by the verb to be that often works as a proper cage. According to Nancy, it is only possible to say one thing about this ça: This ça exists, freed from the immobilizing status of Being (Nancy, 2017, p, 90). When sex refuses to be confined to only one definition, as sor Juana proposes - in Nancy's words, when sex is indicating a singular and individual act (instead of a general and universal condition) what we have is the liberation of sex from the suffocating realm of "nature" and from the ontological paradigm. 
In another famous composition, the villancicos dedicated to Santa Catarina (Cruz, 1951, pp. 163-81), in particular in the first stanza of the coplas of the villancico VI, we find the resolution to the entire enigma surrounding sor Juana's concept of sex as something that does not belong to the sphere of Being:

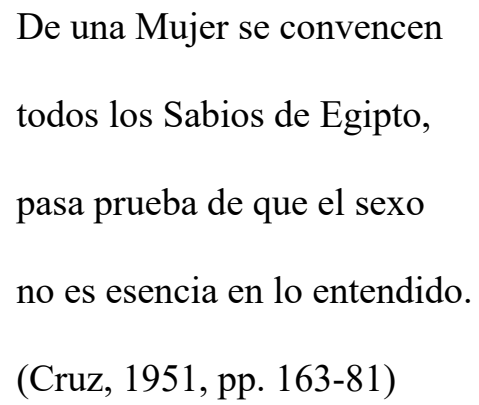

Arguing that sex does not constitute an essence into the sphere of intelligence ("[...] el sexo/ no es esencia en lo entendido") means precisely that the existence of "sex", according to sor Juana, is placed outside of Being and into the bodily and corporeal sphere.

The problem of sex, in conclusion, is not connected to what someone is (for example, if one is a man or a woman), but rather pertains to the sphere of what a body does and makes in relation to the Other. In this sense, Nancy (2017) interprets sex as a bodily act that exists in relation to otherness, and it is this contribution that is most useful if we are to understand the verses in which sor Juana expresses her corporeality and, at the same time, the existence of an otherness that, even though claiming not to be attracted to, she recognizes. According to Nancy (2017, p. 144, p. 153), the psychoanalytical subject is basically presented as unable to exist outside of itself (something that sounds obvious, since the Latin etymology of the word "existence" has already taken into account the idea of being out of the self), and any possible exception is to be treated as an abomination or a rift in need of healing. 
In view of the above, it should now be possible to understand why I decided to avoid La Respuesta in this chapter dedicated specifically to sor Juana's idea of sex. Rather than retreating within the limits of gender, I instead selected Respondiendo a un Caballero del Perú as my primary source. Indeed, it is this text that can best subvert the reduction of sex to a definition influenced by biology, genealogy, sociology, or psychology.

The main problem with sex in sor Juana's universe is that the appearance of the term "sex" in works by female authors - especially one writing under the inquiring eye of the Inquisition — not only represents a fascinating and intricate topic that can all too easily be received as a confession, but also one in which nothing can be too explicit. On the one hand, one can see the influence of specific philosophical traditions, such as Hermeticism and Neoplatonism, on sor Juana's work, which constitutes a challenge to the classical interpretation of the role played by sex in the 19th and 20th centuries.

Rather than adopting an external model of interpretation, I will take up this challenge from within sor Juana's text. Such a reading from within is a method rather than a methodology, since I do not want to leave space for a "discourse (-logy)" that might prevail upon the text itself. This means I will use a method (or "lens") through which to read the text unhindered by a specific technique of reading, thus leaving the text itself free to speak. On the other hand, the method of reading from within is required if we are to approach, not only this challenge to the definition of sex, but also the definitions of other critical terms, such as "origin", "position", and "genealogy". This approach allows me to respect sor Juana's text without reducing it to a "case study". Reading sor Juana's texts from within highlights the fact that they are written using poetic language - as if the question of sexuality might necessitate and encourage the use of poetry as the unique 
mode of writing able to express all of the folds and creases of this complex topic. Indeed, in Jean-Luc Nancy's Sexistence, even though it is a philosophical work, we find numerous literary excerpts and for this reason, it is fruitful to establish a dialogue between sor Juana's poem and this essay.

Nancy’s (2017) Sexistence is deeply informed by poetry and built around different literary excerpts via which Nancy unveils the link between sex and language. In the first chapter of this dissertation, it has been possible to appreciate the link between the subject and language in sor Juana's work. Now it will be possible to extend this link to also encompass the concept of sex. Furthermore, the link between sex and language will be revealed to be even stronger than the link between subject and language established in the first chapter. To explain why sor Juana denies having a sex, and also denies binary logic, I need to introduce the joint issues of untranslatability and irreplaceability, since the extreme and absolute embodied uniqueness revendicated by sor Juana is a strong critique of any possibility to be forcedly placed into a fixed and essentialist category of sex. Instead of other forms sor Juana uses poetic language to express her concept of sex in a definite and intentional manner. The reason for this is the same one that urged JeanLuc Nancy to base his discourse on literary examples. In fact, the crucial quality is the ability of poetry to embody something that is otherwise impossible to convey. A poem is, as a matter of facts, impossible to be translated, not only among different idioms, but also into the space of a single idiom. Each translation of a poem is a new rewriting of the text and for this reason a new, different poem. The term "poem" has its roots in the Greek verb poíesis ("to create"; Hoad, 2002, p. 359), which may explain why poetic language is characterized by a strong materiality and corporeity. This is the reason why a poem, which represents a radical singularity that has its own body, cannot be translated without 
losing its body and acquiring a new one. This "body" is formed by all the particular sounds, assonances, semantic networks, rhetorical effects, and rhythms that each poem conveys.

Within the idea of the corporeity of language, we have to accept that when we read something (in this case, poetry), it is shaped and forged by the very concept of materiality (that is, the matter that precedes all matters) rather than seeing the corporeity of language as a simple construction-something that is built starting from several objects, like a building that is made of different materials. This corporeity is the materiality of the signifier. In this sense, Derrida (1974, p. 7) states in Of Grammatology that writing is the "signifier of the signifier", because it is the part of language that is neither completely replaceable nor translatable. Expanding upon this latter idea of something that is not completely replaceable or translatable, the link between language and poetry can be imagined as a love relationship in which the person we love (that is to say, the specific word used in the poem) is precisely that singular person (or word): "He", "she", or "they" are irreplaceable and untranslatable into someone else (another word with a similar meaning). In accordance with Nancy and Derrida, poetry represents the ultimate and clearest example of what writing is. In other words, writing has to be understood as an unrepeatable and untranslatable act.

More precisely, as Nancy (2000, p. 74) argues in his essay Corpus, writing is the body, le corps. While reducing the issue to a very rough and oversimplified draft, according to Derrida (1971), it is not writing that needs a body to be represented but, on the contrary, it is writing that gives the bodily matter (the signifiers that constitute the act of writing) to the material body of the writer. Yet these two perspectives do not stand in opposition. Rather, as we will see in the interpretation of sor Juana's texts and her answer 
to the Peruvian gentleman, they are co-dependent and equally important to our analysis. Indeed, sor Juana herself plays on the multiple meanings of the term sex-the act, the function, the biological and social determination, or indeed, the organ.

\section{Sex, s'Existence, and Sexistance.}

Throughout the history of philosophy, sex has featured prominently and is the subject of a myriad books, articles, and essays. However, I sought a specific insight on sex that might allow me to interweave sex and subject and, in the same entanglement, to connect on the one hand, the final verse of Primero Sueño, and on the other, the answer to the Peruvian gentleman that constitutes the heart of this chapter. For this reason, Jean-Luc Nancy's (2017) essay Sexistence is helpful, allowing us to focus on the term sex as an act that maintains a balance between its own different meanings and its complex relationship with language.

As stated above, I noticed significant assonances between sor Juan's notion of "sex" and Jean-Luc Nancy's (2017) idea of sexistence. Sexistence is not an isolated essay dedicated to the body and sexuality, as indeed this topic is tackled by Nancy in several preceding works. ${ }^{28}$ As explained earlier, the concept of sexistence works perfectly with sor Juana's idea of having a sex, since both authors challenge the common approach to "sex" as something that someone is, rather than something that someone does.

In Sexistence, sex is approached, not as a status, but as the act of sex. Nancy (2017) specifies that he will not refer to sex as sexual difference, diverse sexualities, sex as the organ, or indeed as a function, but rather to sex in and of itself - the act:

\footnotetext{
${ }^{28}$ I am referring specifically to Corpus (Nancy, 2000); L' " il y a » du rapport sexuel (Nancy, 2001); L'intrus (Nancy, 2010); and Del Sesso (Nancy, 2016).
} 
Nous sommes en vérité au point crucial de ce qui se nomme «le sexe»; non les différences de sexes, ni les sexualités différentes, mais le sexe en lui-même, c'est-à-dire en tant qu'acte et non en tant qu'organe ou fonction. (Nancy, 2017, p. 11)

Exciting, exceeding (excédent), and exasperating (excédant), the act of sex is configured according to a quotation offered by Jacques Derrida (1967) in L'écriture et la difference, which Nancy appropriates in order to point to in a comment about the Lacanian idea of sex and castration. The quote reads as follows:

L'organe accueille donc la différence de l'étranger dans mon corps, il est toujours l'organe de ma déperdition et ceci est d'une vérité si originaire que ni le coeur, organe central de la vie, ni le sexe, organe premier de la vie, ne sauraient y échapper. [...] L'homme vrai n'a pas de sexe car il doit être son sexe. Dès que le sexe devient organe, il me devient étranger, il m'abandonne d'acquérir ainsi l'autonomie arrogante d'un objet enflé et plein de soi. Cette enflure du sexe devenu objet séparé est une sorte de castration. [...] L'organe, lieu de la déperdition parce que son centre a toujours la forme de l'orifice. L'organe fonctionne toujours comme embouchure. (Nancy, 2017, p. 11)

According to Derrida, desire is the basis upon which Lacan demonstrates how the process of castration functions. However, Derrida suggests that the position is inverted, and sex is no longer something external that is castrated by desire the moment it becomes an organ. To the contrary, according to Derrida, sex cannot be castrated since it is an organ that always functions as a mouth and an opening (embouchure) and not as an external and phallic element (Nancy, 2017, p. 11). Thus, in this sense, "my" sex can never 
be "mine" and, more important, sex is no longer a phallocentric idea, because the opening necessarily implies Otherness. This opening or mouth does not coincide completely with Luce Irigaray's (1980) conception of the mouth (or better, the lips). In her essay "When Our Lips Speak Together", the lips are part of an exchange: "The whiteness of this red appropriates nothing. It gives back as much as it receives, in luminous mutuality" (Irigaray, 1980, p. 70). The stress here falls upon the mutual relationship of the lips that give back and receive. On the contrary, the mouth that Derrida and Nancy describe is a mouth that can, to again quote Irigaray (1980, p. 70), only take without giving "back as much as it receives", because it completely refuses the role of the phallus as it is conceived in the psychanalytical tradition. The opening of the mouth embodies an act of sex in which the affirmative penetration of the phallus is no longer central because, focusing on the mouth, the psychanalytical order is subverted and sex, along with language, is based only on the acts of reception and listening:

Le gouffre-toi n'est gouffre que parce que je m'y engouffre: quel qu'il soit, vagin, bouche ou anus, pénétré par membre, doigt ou langue, il se fait sentir à chacun, au pénétrant et au pénétré, comme le tout au-fond sans fond dont la pénétration signifie en effet profondeur, recueillement, compréhension, divination, méditation. (Nancy, 2017, pp. 102-103)

In the above quote, Nancy explains how the act of penetration is not one that reinforces the traditional sense of the subject. Instead, "penetration" becomes an act of sex that is an opening to, and swallows (gouffre), the substantial subject. Here, the act of penetration concurs with a different sense of the verb "to penetrate", which means, according to the quote above, depth (profondeur), reverence (recueillement), comprehension 
(compréhension), divination (divination), and meditation (méditation). Through this first position adopted in Sexistence, it is possible to move not only toward a non-phallocentric idea of sex, but also toward a non-phallocentric idea of the subject. In fact, when sex is not considered as sexuality, sexual difference, as an organ, or indeed as a social paradigm, we can more easily consider the possibility of adopting a new standpoint that allows us to shift from a classical psychoanalytic paradigm — one centered on the phallus - to a paradigm that accepts the term "sex" freed from its conventional connection with the assertion of Being. This new paradigm is able to maintain a connection with a language that is no longer phallogocentric. This non-phallogocentric language is not centered in a subject that, starting from itself, affirms the being of things. Rather, it is the embouchure (opening) of a body opened toward Otherness. This new non-phallogocentric paradigm, which subverts the act of penetration, is centered on sex (understood as the sexual act of opening toward Otherness). However, this process of subversion is the same process that subverted the idea of subject that I examined in the first chapter in relation to El Neptuno Alegórico and Primero Sueño.

The resonance between sor Juana's conception of sex and Nancy's sexistence is evident, since at the core of their argument both authors express a particular entanglement of sex and existence. I would like to start this dialogue going back to the first chapter of this dissertation to recover some useful elements in order to have a clearer idea of why sor Juana can "exist" even if she claims to have a body only as a repository for the soul. First of all, it is not essential to evoke the separation of body and soul, as it became later theorized in Cartesian philosophy. By saying that her body has no sex, and for this reason it is abstracto, sor Juana is following the scholastic theory that distinguishes body and soul, yet at the same time, she is implicitly saying that there is further possibility for the 
body to have sex and, for having sex, to retrieve both its senses and its singularity. However, this possibility coincides with something that is not generally identifiable with an object, since the poem clearly states that sor Juana is not a woman because she does not feel any inclination or desire for anyone.

Focusing on this possibility or excess, it is possible to find the first connection with a passage in Jean-Luc Nancy's (2017) Sexistence, in which the very meaning of the neologism sexistence is presented:

$[\ldots]$ comme une excitation s'excite, s'exalte, s'exaspère et pour tout dire - en ne disant peut-être plus rien - s'existe: se lève et se propulse dans l'existence en tant que l'un au moins de ses plus énergiques ressorts - pourtant aussi bien le moins nécessaire, le plus excédent (sinon même excédant). (p. 11, emphasis added)

The reason why, in the above quote, Nancy can connect the excitation to a s'existence that alludes to something that exceeds and at the same time is both excessive, as a surplus (excédent), and infuriating (excédant), is based not only on a simple assonance of the terms in which the prefix ex-plays its fundamental role, but also on a reason that sor Juana knows very well. Indeed, when sor Juana claims that her body is abstract, she is using a term that in the 17 th century was strongly linked with its Latin etymology: abstrahere, which means precisely to "abstract from" (Hoad, 2002, p. 2). Analyzing this passage, it is evident that according to sor Juana, her body represents what "exists" because, as it is important to remember, the verb "to exist" and the adjective "abstract" have in common a similar etymological meaning. Indeed, "to exist" comes from the Latin verb exsisterre, formed by the preposition ex- and a peculiar form of the verb stare, and it means literally to stay out (Hoad, 2002, p. 160). This latter sense of the verb "to exist" 
provides the connection between the terms used by Jean-Luc Nancy to introduce the neologism s'exister. In this sense, the excess of sex over Being is the same excess that allows sex to exist out of Being into the very space of existence.

The apostrophe between se(xe) and exister is the kingpin of the connection between sor Juana's poem and sexistence. Moreover, the structure of the neologism is extremely useful if one wants to understand sor Juana's reply. The apostrophe in s'exister separates (but in a certain sense, also possibly connects) two parts, but the separation does not divide what is unavoidable from what is a surplus. According to Nancy (2017), sex and existence are both excesses and they can be considered as a surplus or an exceeding part. The previous quote about the definition of sexistence emphasizes that sex is something excédent and excédant. However, later in the same essay, existence is also considered as an excess. Indeed, even if it is considered as "my existence" or "your existence", according to Nancy (2017, pp. 65-66), existence is rather impossible to appropriate because it represents that which exceeds the relationship between "us and ourselves"- that which defines the Cartesian concept of subject:

L'existence est le nom de cet excès dès lors qu'il se désigne comme nôtre, c'est-à-dire comme en nous ou à travers nous le surgissement de la démesure, de l'inappropriable, de tout ce que nous nommons en termes négatifs ou soustractifs comme si nous manquait toute autre possibilité de désignation. (p. 66)

At the same time, this peculiar kind of excess (démesure) in Nancy's own words arrives in and through us as the appearance (surgissement) of something that is non-appropriable. In this movement, the existence remains unlabeled because, as Nancy underlines in the quote, the existence is what we name in negative terms since we lack any possibility of 
designation (designation). To better understand this passage, we have to consider that Nancy says that existence is the ultimate name of the excess after a section entitled "Technique et transcendence", in which he establishes a connection between sex, the sacred, and language. It is possible to think about the sacralization of sex throughout the history of philosophy, traditions, and popular culture, and in the same terms in which we can think about language, since both sex and language represent the two elements that make possible the individuation of "human kind" (Nancy, 2017, pp. 66-67). In other words, sex and existence can be translated, in sor Juana's words, as that which is abstract. The challenge now is to discover what is sex and what is existence in sor Juana's poem Respondiendo a un caballero del Perú, and whether it is possible to read the poem as a whole - that is to say, as a s'existing poem.

The first quatrains upon which I commented above in the third section allude to two accounts of sexual violence. What is interesting here is that sor Juana claims that there are no possibilities to change sex because of the absence of that violence. Therefore, the first response to the invitation to change sex is refused implicitly, stating that such a change is either the consequence of violence, or an act of violence itself. The third quatrain begins with an apophasis - a very common rhetorical device in Spanish baroque literature in which the author introduces a topic declaring that she or he does not want to mention it. However, the argument that is often introduced using the apophasis, according to Nancy (2017), is not only sex, but also language:

Des cultes et des règles sociales en témoignent avec abondance. Le langage a toujours été ce que Valéry nomme «saint langage»: apophasies, magies verbales et poésies le montrent dans toutes les cultures. Sans hasard, dans les deux cas nous retrouvons des indices de sacralité. (p. 65) 
When sor Juana writes that she knows nothing about "these things", she is not only using an apophasis, but also creating the perfect prelude to the following affirmation: She only knows that she decided to enter a cloister to avoid any verification of her sex. The link with Sexistence is now established, not only by the fact that sor Juana regards sex as an action more than a way of being, but also by the fact that she is asserting that the specific relation between existence and sex can be found in the same action that performs the apostrophe in the word neologized by Nancy: s'existence - that is to say, an act of separation that simultaneously functions as a connection.

Establishing this peculiar relation between existence and sex, the text of sor Juana's poem establishes a dialogue with Nancy's essay. The answer contained in the poem begins with the affirmation of the grammatical subject "I" (Yo no entiendo de esas cosas) — a word that, as stated in the first chapter of this dissertation, is undetachable from sex, and ends with a fading subjectivity, confused into a generic plural of those who might be more interested in talking about sex ( $Y$ dejando esta cuestión / para que otros la ventilen). At the same time, sor Juana's answer to the Peruvian gentleman begins and ends with an apophasis, showing that sor Juana is not interested in talking about sex in terms of what today might be defined as a highly essentialized biological identity. Nonetheless, in creating this trajectory, sor Juana is able to convey, from beginning to end, an entire speech about sex and existence, in other words: about s'existence.

Behind the lack of interest showed by sor Juana in contemplating the invitation of the gentleman to turn herself into a man, there is more than a simple refusal. Furthermore, behind the argument that sex is not only a condition that we can change, there is an anticipation of what today is referred to as "gender roles". Finally, behind the verses in which we read that sor Juana is not a woman because nobody can "use her" as such and 
she cannot behave as a woman, there is a perception or an intuition of a performative theory of sex. Beneath all of these passages is hidden a clear triangular connection between s'existence, desire, and violence - albeit one that works slightly differently in Nancy's Sexistence, even if both authors use almost the same means to arrive at their respective conclusions. Indeed, in sor Juana's work, the role of desire is crucial to her demonstration that her body exists, but also that her body does not have a positive reply to the question "What is your sex?". Moreover, she has no positive answer to the question “Do you have sex?". Despite the absence of a positive reply, she answers emphasizing her own existence as a s'existence that resists (any) categorization and within which it is possible to identify an absolute refusal to attribute the quality of existing only to what can express desire, or that adheres to an ontology of sex.

To better express this resistant s'existence, it might be useful to adopt a different neologism: S'existance also simultaneously echoes both Derrida's différance, and the word "resistance". In the expression s'existance that I will use further, there is the sense of the act of resisting singularity, interpreted as an unreplaceable difference (différance). In this way, the cloister becomes the sacred space in which an unspoken sex and an abstract body resist and s'exist. Within the walls of her enclosure, sor Juana lives in s'existance against any ontology of sex that functions only if a desire is present or if the act of sex is carried out. In other words, s'existance is a form of resistance against the ontological criteria to determine the existence of something or someone, and also a resistance against the mere idea of an ens that comes into existence only through universal features.

In conclusion, the poem by sor Juana puts centerstage some crucial points that mark the history of sex and existence. The first point is the impossibility to change sex 
simply to obey a pre-established frame that decides whether certain actions are coherent (or not) with someone's sex. This suggestion is promptly addressed by sor Juana via two examples with a clear reference to violence (the rape perpetrated by Tarquinius and Salmacis). The second point tackles the refusal by sor Juana to allow her sex to be defined. Despite this refusal, in the poem it is possible to find a fascinating definition of sex that combines both a glimpse of the theory of the discursive limits of sex as developed by Judith Butler (1994); and of sex intended as an action with a clear performative value, also developed by Butler (2004). The third point is the possibility that a body can also exist without an explicit desire toward the Other. This affirmation does not question Nancy's essay, but in a certain way expands the notion of s'existence to the very limits of a sex that not only affirms itself through an apophasis, but that is also capable of expressing, at the same time, a form of singularity that exists also in its absence.

\section{Why Is the Question of Sex in sor Juana Inés de la Cruz's Texts so Important Today?}

The application of sor Juana Inés de la Cruz's work in a modern context implies a reconfiguration of many key terms and concepts that, in contemporary theoretical debate, have a different use or meaning. This process of reconfiguration has as its first and most obvious outcome the problematization of these terms, as well as their subsequent deconstruction. The terms "gender", "genre", and "sex" are the most prominent terms that undergo this process. The necessity to think differently about these three terms is due mainly to the fact that sor Juana Inés de la Cruz cannot conceive the pairing of sex and gender in modern terms. Secondly, there is a problem of translation. Under the term "gender", it is now possible to recognize a strong political and sexual foundation that sor 
Juana could not have foreseen in the 17th century. Indeed, the corresponding old Spanish word "género" still had a strong connection with the original Latin meaning of "homogeneous group", which in English has its own translation into the term "genre". In other words, "género" in sor Juana's idiom, and "genre" in Jean-Luc Nancy's idiom, translate both the English words "gender" and "genre". ${ }^{29}$ Sor Juana's refusal to define the sexual group of belonging, as the declaration of neutrality of the body that escapes any gender trouble (Butler, 1990), is a pivotal act if we are to understand the consequences to the idea of género that such a stance regarding sex generates.

In the 17th century, according to the Diccionario de Autoridades (1734), the word género had four possible meanings. Three are related directly to the Latin etymon genus, and their meanings are therefore related to the idea of belonging to a homogeneous group. Turning now to the first entry from the Diccionario de Autoridades (1734):

Diccionario de Autoridades tomo - IV (1734)

GÉNERO. s. m. El ser común a muchas cosas entre sí distintas o diferentes en especie. Es voz tan universal, que comprehende todas las matérias de ciencias y artes: y assí arreglándonos al uso más común de los Diccionarios, se omiten los que son próprios de cada ciencia o facultad. Viene del Latino Genus, que significa esto mismo. FR. L. DE GRAN. Trat. de la Orac. part. 1. Viernes en la noche, §. 1. Porque no quede algún género de tormento por probar, a los que ningun género de deleite quisieron dexar de gustar.

\footnotetext{
${ }^{29}$ The difference between genre and gender that appears in English is untranslatable in many other languages that, like Spanish, have only one word to express both meanings. Regarding this interesting case of untranslatability, as well as the invention of the term gender, I would like to make reference to the entry "Sex, gender, difference of the sexes, sexual difference" in the Dictionary of Untranslatables (Cassin, 2014), as well as to the history of the difficult translation of the text Gender Trouble by Judith Butler as narrated in Against World Literature by Emily Apter (2013).
} 
The interpretation of the term género is marked by two interesting expressions: "El ser común a muchas cosas" [to be common to many things]; and "voz tan universal" [such a universal voice]. According to these expressions, the term "género" refers to something that is collective, common, and universal.

Nonetheless, there is a fourth meaning of the term "género" that the historical dictionary (Diccionario de Autoridades, 1734) records in the following way:

\section{Diccionario de Autoridades - Tomo IV (1734)}

GÉNERO. En la Gramática es la división de los nombres, segun los diferentes sexos, o naturalezas que significan, y corresponden a los artículos que se aplican: como el, la, lo. Latín. Genus. BOBAD. Polit. lib. 3. cap. 15. num. 35. Tambien se comprehenderá la muger, si exerciesse la tal arte, pues el género masculino comprehende al femenino. ALDRET. Orig. lib. 1. cap. 10. Aquí bien claro dice que vulgarmente decían Cubitus, si bien sabia que su propriedad era del género néutro. [iv.42]

The appearance of the term "género" in the above entry shifts the interpretation of sex from something that regulates gender, toward something that has a grammatical gender, such as a name, object, or noun.

Therefore, because of the peculiarities of the linguistic frames within which they work, Jean-Luc Nancy and sor Juana Inés de la Cruz can think together, and under the same word, the English terms "gender" and "genre". This ambiguity does not in reality represent a confusion of the two concepts, which in some manner merge hazily into the same space of a single term. Rather, it is a clarification of some aspects that the term "gender" shares with the term "genre"-a sharing that is otherwise not obvious, because of the disambiguation attributed by the English language. In separating the meaning of 
"gender" as a sexual condition from the term "genre" as "homogeneous group", it is possible to have two pairings: the pairing of sex/gender; and that of sex/genre, which in Spanish (but also in French [genre], Italian [genere], and German [Geschlecht]) can have only one expression: sexo/género or sexe/genre.

Of course, if we employ a single term for both gender and genre, the functioning and meaning of the term "sex" also changes. This is the crucial point on which I need to focus in order to finally explain sor Juana's answer. Indeed, sor Juana plays on both possible meanings of the term "sex", however, since she is writing in an era that does not separate between the two meanings of "género", she does not need to name the word "sex", because any reader at that time would have no doubts about the fact that she is talking about sex. However, this fact remains hidden to contemporary readers who collocate any discourse about sex into the dichotomy sex/gender. It is for this reason that Jean-Luc Nancy, who clearly knows that he needs to re-collocate the term sex into the pair "sex/genre”, makes sor Juana's discourse crystal clear.

The importance of juxtaposing the unusual pair sex/genre with the pair sex/gender is fundamental to the gaining of any understanding, not only of the literal meaning of sor Juana's words, but also the contribution made to the philosophical debate regarding the potential that the term sex has, and that has remained hidden for so long because of the disappearance of the pair sex/genre. As a matter of fact, in the first instance, the term "sex" in the pair sex/gender plays the same role as "nature" in the more famous pairing of nature/culture - a role that, in my opinion, seriously limits its discursive potential. In the second pair, sex/genre, the word "genre" embodies the limited potential of the term "identity" in the pairing of singularity/identity, here suffering from the limitations imposed by the strong meaning of category, group, restricted identity politics, or universal 
definition, while the word sex is now free to express its own bodily, corporeal, unique, and singular character.

As a consequence of the above, in the pair sex/genre, finally the term "sex" can resist any categorization and can yield a creative, rather than restricted space. This role played by the term "sex" is completely different from the role that the same term plays in the pairing of sex/gender, in which it was regulated and strictly controlled by biological and discursive norms. In conclusion, in sor Juana's work, the concept of sex functions as a form of resistance to the idea of genre. In this way, we should not consider a separation between sex and gender, but rather a separation between sex and genre.

The common meanings attributed to the dichotomy "sex/gender" in contemporary critique of sor Juana's work are informed by notions that obviously post-date the time in which they were written. For instance, in Sor Juana's Second Dream: A Novel by Alicia Gaspar de Alba (1999), dedicated to sor Juana, the use of the terms "sex" and "gender" are regulated by the current meanings of the words and often the character of sor Juana uses the word gender according to a meaning very distant from sor Juana's time. Yet these meanings of "sex" and "gender" fail not only for chronological reasons, but also and above all for theoretical reasons. In sor Juana, the term "sex" is not conceived as an organ (or indeed any other biological derivation), and the term género is not conceived as a condition or a social role. I specifically underline these important distinctions, also in the works by Jean-Luc Nancy, as otherwise all of the passages in which sor Juana uses the terms sex and gender-either using metaphors or rhetorical references to sex as an act (instead of a fact), and genre as a homogeneous group (instead of gender as a social condition) - might fail to move beyond mere literal interpretation, and thus any allusions 
to the specific sense of "sex/sexistence" as a form of resistance against genre will be impossible to detect.

It is important here to describe how sex functions as a form of resistance. The first step requires a redefinition of the relationship between genre and sex, making both terms independent from one another, reestablishing their independence. In doing so, thanks to the theoretical perspective adopted, it will be possible to consider the word "sex" as a resistance against every form of embodiment in a specific category (genre). The main (and in my opinion most interesting) feature of the concept of sex in sor Juana's work is that sex no longer functions in the contemporary sense to which we have become so accustomed. In the pair sex/gender, it is autonomous, becoming a strategy of resistance to genre. The great contribution offered by Respondiendo a un caballero del Perú consists precisely of the possibility to think the concept of sex beyond the pairing of sex/gender. Using a Saussurean metaphor, ${ }^{30}$ sor Juana plays on a chessboard that lacks the chess piece "gender" (intended here as a "sexual social condition") and as a result has a more powerful chess piece_- "sex" - to play with. Thus, once "gender" is deprived of its meaning (relative to sex) and becomes fully translatable into the word genre, necessarily, the word genre returns to its Latin sense of "homogeneous group" (identity). At the same time, if we consider sex as a form of resistance to genre, sex becomes sexistance because it is freed from any form of belonging, ${ }^{31}$ and it becomes free to express, not only a concept of sex no longer limited to the option offered by the meaning that one may attribute to

\footnotetext{
${ }^{30}$ In this metaphor the French linguist Ferdinand de Saussure (1971, pp. 125-26) makes a comparison between langue and a chessboard. Each signifier represents a chess piece with a meaning and a range of possible uses. Consequently, the worth of each signifier depends on the moment and on the configuration of the chessboard during the game.

${ }^{31}$ About the complexities of the translation and meanings of the term "gender", see also what Judith Butler writes under the entry "Gender" in the Dictionary of Untranslatables (Cassin, 2014, pp. 377-79) in box 1, entitled "Gender and Gender Trouble".
} 
gender, but also a concept of sex that lacks any possibility to be categorized, therefore also expressing the concepts of difference, of "non-connection", and of "non-belonging". On the other hand, when the word "genre" returns to its conservative function of circumscribing an identity, it unveils its hidden aspects. The most important outcome of the transformation of "sex" into "sexistence" is the subversion of the traditional belief in which "sex" is the unchangeable and unavoidably present biological determination, while "gender" is the subjective, free, changeable definition. As a matter of fact, in this new pairing of sex/genre, sex/sexistence represents the "underived" and "without origin" side of the equation, since sex is primarily a free act. Genre on the other hand, embodies what I referred to as the "hidden aspects" of "gender"-aspects that make "gender" a predetermined and determinant category that cannot be changed - since it indicates what subsists before a subjectivity (for example, its ancestors and genealogy). In light of this now fixed past, the word "genre/gender" defines the unchangeable identity of subjectivity.

As a provisional answer to the question that opens this section- "Why is the question of sex in sor Juana Inés de la Cruz's texts so important today?"-it is possible to affirm that sor Juana's insight into sex is helpful, also in a contemporary context, as a means by which to adopt a provocative perspective on sex that is no longer enslaved by gender, and that does not respond to, nor depend on, any biologically or genealogically informed structure. In doing so, the perception of sex can be freed from the traditional psychoanalytical frame, becoming something that allows a practice of difference that not necessarily requires a connection with the idea of "diversity". Here "diversity" implies a process of identification and the acceptance of belonging to a community in which "I" is a replaceable example of a universal category that entails a binary logic, since it functions 
only according to what I am or what I am not. Conversely, "difference" does not require any universal category to function, and it is connected solely with the impossibility of being replaced.

In sor Juana's work, the concept of sex reveals its ability to occupy a space that is "subjected" neither to binary division, nor to definition. What we read is a short, sharp, and acute reaction to a system that regulates our adhesion (what I am), but also our dissent (what I am not), since it is a system based only on a diversity that does not open itself to singular difference. The attempt to subvert the system—crucially not any specific system, but rather the very idea of systematization - is connected, of course, to the subversion of the Cartesian philosophical model that configures the most common type of structures and power structures with which we currently engage. Therefore, to read sor Juana's texts today, interpreting the possibilities of the text from a post-structuralist perspective possesses not only theoretical relevance, but also political potential. The problem of overcoming a given structure, system, or model is a well-known (and thorny) one. In fact, it is always difficult to understand if a process of overcoming is actually fruitful, or if we are merely exchanging one structure for a new or different one, perpetuating the same limitations and controls, simply adopting a different name. This "thorny problem" is perfectly summarized in an important passage by Gilles Deleuze in his essay of 1967 regarding the second criterion of structuralism: "A quoi reconnaît-on le structuralisme?" ("How Do We Recognize Structuralism?"). He states: "For if the place is primary in relation to whatever occupies it, it certainly will not do to replace God with man in order to change the structure" (Deleuze, 2004, p. 175).

The challenge that sor Juana poses to the idea of having (a) sex is not only provocative for her time, but also provides the contemporary debate with a fresh 
standpoint that does not adhere to Cartesian philosophy, belonging instead to an intellectual space that does not allow itself to be caged, either logically or chronologically, into clear and distinct categories. Regarding the latter point, I would like to underline once more that in the previous chapter, the reading of Primero Sueño clearly offered a critique of the Aristotelian categories that were presented by sor Juana as insufficient to narrate the entirety of existing things in the world. In conclusion, by adopting a method of reading of sor Juana's texts in which the word "sex" is not only connected with a biological or social sexual construction and sexual operation, it becomes possible to think the concept of sex as resistant to genre.

It is not my intention to question the classical feminist interpretation of sor Juana's writings, which underlines her brave and strenuous defense of women's rights. Rather, I challenge the idea that sor Juana's claim for women's right to write and study is proposed from within - that is to say, by a woman. On the contrary, I argue that sor Juana indicates the rights of women. By the verb "to indicate", I mean "to point to" or, in Latin, monstrare. Therefore, she points to (monstra) and she is the very monster who is "pointing to"- the literal monstrous creature. In the following chapter, I will demonstrate how this idea of "the monster" is connected to the question of the relationship between sex and genre, introducing the figure of a very particular monster: the Phoenix. 


\section{Third Chapter. The Phoenix: Resisting the Norms of Language}

\section{Introduction: The Phoenix and the Impossible Space of Life Death}

The second chapter revealed sor Juana's vindication of sexistence-a singularity that claims its own existence beyond the sphere of Being. This claim took the form of a revindication of living existence against that which might otherwise seek to deny it, entrapping it within a rigid definition that transforms life into its polar opposite: death. Had I ended my analysis with the poem Respondiendo a un caballero del Perú, it might now seem that sor Juana's discourse is limited to the establishment of simple, rigid, binary oppositions: sex/genre, singularity/universality, existence/Being, life/death. If everything had culminated in these rigid binary oppositions, such a move would have generated a new fall, again, into the sphere of Being. How, then, can I say what "I am" without using the verb to be, thus trapping "myself" into a rigid process of identification? The answer that sor Juana provides, is to identify herself with something that does not uniquely belong to living existence (life) or its reduction to Being (death): the Phoenix.

This third chapter focuses on the poem Romance que respondió nuestra poetisa and its central figure, the Phoenix. The figure of the Phoenix provides the perfect metaphor for the complexities of a non-rigid opposition between life and death (existence and Being) — one firmly grounded in the principle of non-contradiction. Indeed, as I aim to demonstrate in this chapter, the Phoenix transforms the rigid opposition between life and death into what Jacques Derrida (2019) coined "life death". My analysis of sor Juana's Romance que respondió nuestra poetisa will be divided into two sections: Initially, (lines 1-124) I focus on the Phoenix and the impossible separation between life 
and death. Proceeding, (lines 125-200) although still firmly focused on the Phoenix, my attention turns toward the genealogical aspects of this fantastical creature.

In this third chapter I would like to plot a route, from the idea of the Phoenix, which knows no distinction between life and death, to the uniqueness of a creature that occupies such an impossible place. Indeed, through the figure of the Phoenix and the Derridean concept of "life death" that it embodies, I attempt to demonstrate how the sexisting singularity expressed by sor Juana is not merely the act of taking a side (a position) in favor of life and against death, in favor of existence over and against Being, or even in favor of sex against genre. Rather, the Phoenix manifests the impossibility of assuming a position, precisely because it refuses any (op-) position. Therefore, I argue, sexistence cannot be other than an impossible position.

My theoretical framework will lean strongly on the work of Jacques Derrida (2019) and the proximity he suggests between life and death in his text Life Death. The non-opposition that sor Juana suggests between life and death-the non-opposition embodied by the Phoenix - dismantles the idea of position and the principle of noncontradiction once and for all. In the preceding chapter, we saw how sor Juana refused to be identified as either woman or man, and how this refusal affected the definition of a sex that was instead configurated as something singular rather than universal — as a free act rather than a predetermined category. The immediate consequence of sor Juana's declaration - the refusal to be identified with a particular sex - represents a first rift in the principle of non-contradiction, not least as it means nobody can ascribe to her a sexual identity. Sor Juana states that she is not a woman because she cannot be "used" as a woman, nor does she identify as a man; whatever her sex, she prefers to leave it unverified. Is it possible, therefore, to place sor Juana within a sexual continuum, or does 
her radical refusal undermine the very idea of placing something? I argue that in her texts, sor Juana undermines the process of identifying something with a univocal and steady position, in particular within the sexual continuum. Preferring not to define herself, she refuses to undergo this process and to be assigned to a "place" that defines her sexual position.

Considering what sor Juana writes about the figure of the Phoenix, as the creature that knows no difference between (or deferral to) life and death, it becomes clear that also the structuralist idea of a position that is identified through distinctions is affected. The focus of this chapter will be to explain the relationship between the singularity of sex and the impossibility to ascribe a position to something that is unique. This uniqueness, as expressed by the metaphor of the Phoenix, is conceived not in opposition, but in its perennial rebirth, since, as sor Juana's Phoenix reminds us, life and death are neither cultural nor natural status, but rather processes of transition. This theoretical interrogation of identity, understood as a trap in which the structuralist principle of definition through distinctions (I am this because I am not that) leads to a rigid opposition, is not only a theoretical question, but also represents a political revindication of that which does not allow definition. Representing this peculiar relationship between life and death, the Phoenix is thus a metaphor for a process of subjectivation and empowerment that does not adopt an oppositional position.

The metaphor of the Phoenix unites two ideas: the idea of uniqueness and the impossibility of separating the moment of death from life. The uniqueness of the Phoenix resides partly in its status, not as a species, but as a singular and unrepeatable creature, and the impossibility of separating the moment of its death from life, as realized through 
its power of rebirth. These attributes are also present in Derrida's (2019) Life Death. ${ }^{32}$ As will become clear, it is not possible to read and interpret the concepts of singularity and sex within the sphere of Being. The question here is not about "be"(-ing) singular, nor is it about "be(-ing) female" or "be(-ing) male". Rather, it concerns transformation: the movement that the Phoenix epitomizes in its transformation from life, to death, to life.

Sor Juana's cultural background contains a specific myth of the Phoenix that she uses as a reference - a myth that I would like briefly to summarize. The legend of the Phoenix has its origins in the mythology of Ancient Egypt. Eventually, the figure of a mythical bird that is reborn from its own ashes emerges within ancient Greek mythology, as can been seen in the works of Herodotus, Pliny the Elder, and Ovid (authors that sor Juana frequently references). Not only is the figure of the Phoenix one of regeneration; it also represents an absolute singularity. It is the rara avis, the black swan of classical Ancient Latin culture: the rare or unique bird. This is precisely the quality that sor Juana highlights in Romance que respondió nuestra poetisa. If there is any characteristic of the Phoenix that justifies the comparison between sor Juana and this mythic creature, it has to be the absolute singularity of the bird. ${ }^{33}$ The connection with life (and) death should be clearer at this point: The Phoenix indeed embodies that impossible moment of passage from life, to death, to life again. Rather, it is a movement with neither origin nor

\footnotetext{
${ }^{32}$ In an essay titled "Tracing Life: 'La Vie la Mort'”, Vicki Kirby (2009) explores the connection between divisibility and deconstruction. Kirby also grounds her argument on the seminars held by Derrida in 1975 . Kirby shows an interesting link between physics, biology, and différance. While I do not explore the "life death" from a scientifically informed perspective, methodologically I do try to show how, in the metaphor of the Phoenix, sor Juana transfers the same image of a différance that "arises from within writing" (Kirby, 2009, p. 118).

${ }^{33}$ Regarding the influence of the myth of the Phoenix in baroque novohispano poetry, see the essay "El mito del Ave Fénix en la poesía barroca novohispana: influencias y relaciones comparadas" by Jorge García-Ramos Merlo, published in 2020 in El largo viaje de los mitos. Mitos clásicos y mitos prehispánicos en las literaturas latinoamericanas (Tedeschi, 2020). The essay is important because in presenting the myth of the Phoenix, it traces a comparison with the Mexican deities Quetzalcoatl and Huitzlihuitl, both of which are associated with two Mexican birds, the quetzal and the colibri, which are famous for being both rare and marvelous (García-Ramos Merlo, 2020, 30-33).
} 
destination, but also a movement that covers no distance between life (and) death. Following Jacques Derrida's (2019) characterization of “life death", sor Juana's Phoenix occupies the (impossible) space of the conjunction "and", thus written in parentheses:

But in saying "life death" in order to approach this other alterity, it is also not a question for me of trying to identify life and death, to say life is death, a proposition that, as you know, can be supported in multiple ways, through numerous well-known paths. The blank [trait blanc] between life and death does not come in place of and and [et] or an is [est]. (Derrida, 2019, p. 4)

This is the reason why above, parentheses surround the conjunction "and" in its appearance between life (and) death in order to urgently underline the impossibility to find a moment of separation between "life death"—an impossibility that becomes easier to imagine with the introduction of the metaphor of the Phoenix. This is also the reason why the title of the text by Jacques Derrida is Life Death, without the conjunction "and". The impossibility of assuming a position performed by the sexisting singularity represented by the Phoenix distorts the meaning of the word "I", as we will see in the poem, each time that sor Juana uses it. The Phoenix indeed represents a sexisting singularity because in being both unique and simultaneously alive and dead, it forwards a form of resistance against the binary thought that lies at the heart of sexual difference. The "I" of the Phoenix is indeed freed from any form of definition, since it puts in crisis the first and most evident form of difference: the difference between life and death.

As I will demonstrate, sor Juana's Phoenix indicates something that is simultaneously, temporally, and spatially alive and dead-something multiple and inseparable. Nevertheless, this moment and this space are so unique in their nature 
(genre) that they are impossible to find or individuate: They do not "exist", or rather (and perhaps better), they are neither present, nor necessarily absent. The fall of this pivotal distinction between different states of Being represents the deconstruction of any structure based on the principle of non-contradiction.

In order to have a clearer idea of the connection between the two texts, I first offer a brief introduction to the main theme and structure of Life Death. The work details the fourteen sessions of a series of seminars that Derrida held between 1975 and 1976. The collection was published in 2019. The seminars are dedicated to the supposed opposition between life and death — an opposition that Derrida questions. Vicki Kirby (2009, p. 121) underlines the way in which Derrida subverts the common idea of reading "presence in terms of absence, or life in terms of death", and the manner in which he criticizes a reading that begins "with oppositional difference". Proceeding, she asserts that "what is life from one perspective is death from another, a superposition of states that does not divide into the either/or of mortality/immortality" (Kirby, 2009, p. 121). This is fundamental to understand how the Phoenix subverts the "oppositional difference", leaning toward a deconstruction of the idea of (op-)position.

During the first session, Derrida (2019) introduces the main points of the seminar. Here, the similarities with sor Juana's considerations are immediately evidentsomething that will become clearer as the close reading of the poem progresses. For now, I would like simply to summarize, using a quote from Derrida's first session to clarify the question of the singularity of the Phoenix, the indivisibility of "life death", and the multifaceted issue of position and op-position : 
I simply wanted to indicate that the same logic could help to distinguish the various semantic registers of life and (et) death (where the and signifies position, juxtaposition or op-position) and life is (est) death where death defines essence as the dialectical process of life keeping itself alive as life, producing itself and reproducing itself, etc. (Derrida, 2019, p. 5)

This quote makes evident the reason I put the conjunction between life and death in parentheses or, in some cases, renounced completely the expected "and". In English, it is no longer possible to evoke the assonance between the French conjunction et [and] and the French verb est [is]. Here, Derrida affirms that there is neither "and" nor "is" between the words "life" "death":

So that, by saying, with the black of a pause or the invisible mark of a beyond, "life death," I am neither opposing nor identifying life and death (neither and [et] nor is [est]), I am neutralizing, as it were, both opposition and identification, in order to gesture not toward another logic, an opposite logic of life and death, but toward another topos, if you will, a topos from which it would be possible to read, at the very least, the entire program of the and and of the is, of the positionality and presence of being, both of these being effects of "life death". How to think position and presence as effects? (Derrida, 2019, p. 6)

This second quote explains even more clearly how the "pause" between "life death" indicates a "beyond" [au-delà], positing the question of life death in terms of "another topos" (Derrida, 2019, p. 6). This quote is fundamental if we are to reconnect, on the one hand, what sor Juana states in the poem analyzed in the second chapter of this dissertation, regarding her entry into the cloister in order to distance herself from the anxiety of being 
classified as a woman, with the passage in which she affirms that her body is neutral and abstract on the other. This neutrality, chosen as a refusal of desiring this or that - that is to say, to surrender to the principle of non-contradiction - upsets the "program of the and and of the is" (Derrida, 2019, p. 6). According to Derrida, this "program"- the principle of non-contradiction that so characterizes the logic of Western thought - is an inevitable effect of "life death", but simultaneously provokes a repression of "life death". The peculiarity of sor Juana's poem Romance que respondió nuestra poetisa is precisely the fact that "life death" is not repressed, but rather assumes center-stage in her discourse, acquiring a medial position that upsets the logic "of the and and of the $i s$ "- the very "program", to invoke Derrida's term once more, upon which the principle of noncontradiction is grounded.

Indeed, in Romance que respondió nuestra poetisa, sor Juana is replying to an anonymous author that identifies sor Juana with the Phoenix. The metaphorical relationship between the Phoenix and sor Juana is interesting because, as Derrida demonstrates, it allows the reader to think in a manner that goes beyond a gendered or sexed identification. Indeed, the Phoenix is not only an animal - in this case a fabulous creature-but in Medieval terms, it is also a monster. The bird, who resurrects from its own ashes, is generally perceived as a positive, but nonetheless terrible, creature. The Phoenix is an important metaphor for the deconstruction of the oppositional relationship between "life death" which, in its turn, makes possible the deconstruction of duality more generally, and of the sexually differentiated system that imposes itself as the only possible way to think sexual difference in particular. The key is precisely the abolition of the oppositional thought that permeates also those identity politics in which to hold a position means to completely discharge any other position, without the possibility to find what 
Kirby $(2009$, p. 108) calls the decoherent principle of superposition "inasmuch as 'one' particle can be in different states at the same time". Decoherence proves to be of great value if transposed into the reading of sor Juana's poem, since it makes evident why sor Juana does not want to think the Phoenix in oppositional terms. This is the key if we are to understand how to proceed in the reading of sor Juana's subjectivity and her contribution to the debate about sex.

Sor Juana accepts being likened to a Phoenix by the anonymous poet, however, the features of the creature upon which she lingers are not entirely good. Above all, the most evident yet highly significant feature on which she lingers, is the rare eccentricity of the creature. Here, eccentricity should be understood as something that exists outside of any possible act of positioning, but also as something that does not occupy common space; rather, it only exists in a non-shareable place. To say that the Phoenix is an eccentric creature, means that it is also a creature that symbolizes an affirmation of a singularity — one that possesses the language used to name it and that, as we will see, tells its own history, thus changing the program of language.

Of course, sor Juana can choose among several examples of uniqueness, so why precisely does she choose the Phoenix? My suggestion here is that the Phoenix is the metaphor of a singularity that is not isolated, but rather is caught in a perpetual transposition between "life death", between sexes, and between any kind of oppositional status regulated by the principle of non-contradiction. It is clear that sor Juana understands singularity, not as a monadic principle, but as a transition. Nonetheless, it is also important to remember that the transition between "life death" is in no way a transition from life to death, just as any other transitions performed by this singularity in revolt are never linear because "life death" is understood beyond the observance of the principle of non- 
contradiction that thinks the definitions of these two concepts as in contradiction and opposed one to the other: Here "life" and "death" are folding, one into the other.

The Phoenix that emerges from sor Juana's words is simultaneously "decoherent" (Kirby, 2009, p. 108)—representing life and death in divisible (specifically not opposed) moments, or "superpositions" (Kirby, 2009, p. 121). This transition is a becoming that is no longer generated through oppositions, but rather through that torsional movement that Vicki Kirby (2009, p. 121) describes in "Tracing Life: 'La Vie La Mort", and that "strives to reconfigure 'the what' and 'the how' of that individual identity formation".

\section{Introducing and Contextualizing Romance que respondió nuestra poetisa}

The Romance que respondió nuestra poetisa was first published in the Segundo volumen de las Obras de Soror Juana Inés de la Cruz [...] in 1692. The romance is a complex and lengthy reply to another poem written by an anonymous author who arrived in New Spain from Europe. Mexican sor Juana scholar Margo Glantz (2006, pp. 215-341) comments upon this poem in her famous essay “Sor Juana: ¿Hagiografía o autobiografía?”. Glantz focusses on the Phoenix mainly as a monstrous creature and its relationship with other female figures, such as the Sybil and the Muse. Another scholar, David Solodkow (2009), dedicates an essay to the image of the Phoenix in sor Juana, but here, too, the monstrous characteristics of the Phoenix are highlighted. Further examples in which the poem is discussed (see Arenal, 1985; Arenal \& Powell, 1993; Bergmann, 1993; Martínez, 2012) also follow these interpretations, and focus on what I have identified as the second part of the poem (lines 125-200). Indeed, in the second half, sor Juana also clearly argues that the Phoenix is a monster that represents the beginning and the end of its species. Yet, 
despite this broad focus on the second half of the poem, I decided to focus my analysis more on the poem's first half (lines 1-124).

The question that I put to myself, and that I try to answer here, is why sor Juana introduces this line of argumentation in the second part after such a long section (which I define as the first part) that apparently avoids the theme of monstrosity altogether, concentrating instead on the following main themes: a) the Phoenix as the rara avis; b) the Phoenix and "life death"; and c) the problematic identification of sor Juana with the Phoenix. These themes are crucial if we are to understand why sor Juana's idea of a sexisting singularity is not only dynamic, but also impossible to place.

Since this poem is an answer to another poem, I include a brief contextualization of the main issues that the instigating poem raises for sor Juana. This analysis will show how sor Juana reinterprets the classic figure of the Phoenix. Such innovative interpretations of classical figures, hidden as usual under many layers and folds of a semantic labyrinth and enigmas that I attempt to solve, principally target the meaning of the Phoenix in the sense of a subversion of the common belief that sees the creature "simply" as a metaphor of reincarnation and immortality. Sor Juana challenges precisely an image of the Phoenix that differentiates the moment of (its) birth from the moment of (its) death, seamlessly passing from one status to the other, when, in the first part of the poem, to the contrary, she claims that the Phoenix comes back to life in the same moment it dies.

Before entering into the close reading of the poem itself, it will prove beneficial to spend a moment examining the poem to which sor Juana is replying. The poem is shorter than sor Juana's reply, and its tone is comedic rather than theatrical, as is the case with the poem by sor Juana. The Romance que un caballero recién venido a la Nueva 
España escribió a la madre Juana was also published in the Segundo volumen de las Obras de Soror Juana Inés de la Cruz [...] (Cruz, 1692). The anonymous European ${ }^{34}$ poet, adopting a strongly hyperbolic tone, writes in praise to sor Juana, offering her all the themes she will use in her reply. Before defining sor Juana as a Phoenix, the poet addresses her with the term "mother" [madre], a term that does not only substitute a generic "nun", but also refers to motherhood:

\author{
Madre que haces chiquitos \\ $[\ldots]$ \\ A ti van aquestos versos \\ madre sin poder ser madre, \\ (Cruz, 2018, p. 123, lines 1-6)
}

These lines offer sor Juana the possibility to address the question of genealogies in her poem, pointing out, in a very direct way, the fact that it is not possible to have ancestors or descendants, as otherwise she, as the Phoenix, would lose the ability to be unique. ${ }^{35}$ With the term genealogy, I intend to encompass the process of reproduction in a homogeneous group definable as "genre". Sor Juana faces the interesting topic of the impossible genealogy of the Phoenix in the second part of her reply.

The anonymous poet goes on to describe the moment when, reading sor Juana's poem Primero Sueño, he realizes that only an uncivilized person such as himself could

\footnotetext{
34 The anonymous author that arrived in New Spain and dedicates these lines to sor Juana remains anonymous, but his text has been recognized as native Spanish (Cruz, 2018, p. 123).

${ }^{35}$ Contemporary scholars, such as Graciela Hierro Pérezcastro (2005), consider these lines as a testimony of the importance that sor Juana had in the intellectual environment, already during her life: "Los juicios de su tiempo nos hablan del Caballero del Fénix, recién venido a la Nueva España, quien le dirigió un romance 'Madre que hace chiquitos, no es pulla, no, a los más grandes...'” (Hierro Pérezcastro, 2005, p. 160).
} 
miss the fact that if a wonderful poem can illuminate the darkness - an event as rare as it is improbable - then the existence of the Phoenix becomes a more likely possibility: ${ }^{36}$

"Cierto que soy gran salvaje.

Si hay noche en que Apolo luce, ¿qué haya Fénix, no es más fácil?" (p. 128, lines 98-100)

The use of the term salvaje (uncivilized), which was not generally used to refer to Europeans, should be highlighted here in the above stanza. This use of the term is interesting, not least as it represents an inversion of the usual perspective at that time of the Americas and Europe - one that is also strongly present in other sor Juana's poems, as we will see in the last chapter of this thesis.

The following lines (106-108) focus simultaneously on singularity and gender. Indeed, the anonymous poet here claims that a single sheet by "Juana" is more valuable than fifteen pages written by some generic "Juanes"-fifteen sheets written by a plural and masculine declension of "Juana". Here, the author presents the proper name "Juana" in the singular and feminine form, while the masculine "Juanes" is merely a counterpart (instead of being central, as would be expected for a male subject). Additionally, the name appears in the plural form, thus revoking the qualities of uniqueness and singularity that are the typically used to individuate a proper name:

“[...] más vale sola una hoja de Juana, que quince hojas de Juanes". (p. 128, lines 106-108)

\footnotetext{
${ }^{36}$ I use the masculine pronoun because in line 9, the poet defines himself as "el menor de los poetas", or in English, "the minor among poets", using the masculine gender.
} 
This conflation of gender and number, along with the use of the proper name, is a crucial point and provides a helpful mechanism via which to read sor Juana's reply to the anonymous poet from New Spain. It will help to us understand her answer, as well as how she chooses to frame it.

Proceeding, the anonymous poet announces to the reader that he has finally found the Phoenix [hallé la Fénix]. ${ }^{37}$ While the Diccionario de Autoridades (1732) reports cases of the use of the term Phoenix in the feminine, this is rare. Exceptionally, the word Phoenix here is shown in the feminine, while it is generally masculine in Spanish:

hallé la Fénix que bebe

las perlas de más quilates

(p. 129, lines 117, 118)

The author is announcing that he found the Phoenix and that the Phoenix is a woman. It will be possible to see how, in sor Juana's reply, the gender of the Phoenix is approached and unconventionally (re)phrased.

The final lines in the romance by the anonymous poet upon which I would like to remark are those in which the author brings back once more the idea of uniqueness, precisely in the line in which he defines sor Juana/the Phoenix as the most unique [la más única] and the most rare [y más rara] creature to exist in the known world. This will be the first theme addressed in our analysis and our point of departure for sor Juana's text:

la más única y más rara
que hay desde Etiopia a Flandes:
no hable Córdoba palabra;
calle Mantua, Sulmo calle.
(p. 129, lines 121-124)

${ }^{37}$ Fénix appears capitalized here, because the Phoenix is a proper name par excellence and singular by its very nature. 
However, there is another reason that this quatrain is important. On the one hand, it is possible to find another allusion to the uniqueness of the Phoenix when he writes "la más única y más rara" (the most unique and the most rare); on the other hand, this uniqueness is related not only to sor Juana as a person, but also to sor Juana as a writer who does not fear any comparison with the great contemporary male authors, or those of antiquityGóngora, the poet from Cordoba; Virgilio, the poet from Mantova (Mantua); and Ovid, the poet from Sulmona (Sulmo). This passage is of relevance if we are to not only comprehend how the anonymous author of the romance understands the uniqueness of the Phoenix in a very literal way, but also appreciate how sor Juana revolutionizes the concept of uniqueness, transforming it into a singularity that is never disconnected from relationships with others or separated in an absolute status.

The following sections present in detail the themes that sor Juana approaches in her reply: the uniqueness of the Phoenix; the relationship between the Phoenix and the metaphor of "life death"; the issues presented by the identification of sor Juana with the Phoenix; and the impossible genealogy of the Phoenix. The question of "life death" is central in the poem, not only because of its crucial importance, but also in the literal meaning of occupying a medial position. As we will see, "life death" acts as the bridge between the other themes.

\section{The Rara Avis: The Phoenix as a Unique Creature}

The first part of Romance que respondió nuestra poetisa reveals how the metaphor of the Phoenix, in its connection with the metaphor of "life death", is perceived by sor Juana, and especially which kind of relationship can be traced between sex and singularity. The incipit is powerful and instead of submissively dealing with the laudation of the 
anonymous poet, sor Juana bursts into a proparoxytone word (válgate) that rhythmically signals this firm beginning:

$$
\begin{aligned}
& \text { ¡Válgate Apolo por hombre! } \\
& \text { No acabo de santiguarme } \\
& \text { (más que vieja cuando Jove } \\
& \text { dispara sus triquitraques) } \\
& \text { de tan paradoja idea, } \\
& \text { de tan remoto dictamen; } \\
& \text { sin duda que éste el autor } \\
& \text { es de los Extravagantes. } \\
& \text { (p. 130, lines 1-8) }
\end{aligned}
$$

Similar to my close reading in the second chapter, the literal translation of each word of the two quatrains is less important than the focus on some specific keywords that reveal more complexity than one might expect. Summarizing the argument of these two stanzas, here sor Juana is expressing her surprise in reading so many glorifying words about her writings. Even so, this surprise is expressed by adopting a colloquial, plain, and almost crude register that describes a scene characterized by a quite comic atmosphere-as emphasized by the image of a scared old lady that crosses herself [santiguarse] when Jupiter [Jove] shoots his firecrackers [triquitraques]. Analogously, or more vigorously than the old lady, our author is crossing herself in the face of the praising words of the poem that the anonymous Spanish writer dedicated to her. The praise that sor Juana receives as something illogical and remote, offers an opportunity to displace her poem in a similar way led by an idea introduced in the last line by the word "extravagants" [extravagantes]. "Extravagant" used as noun is the name of the letters written by the Pope that are not included in the Litterae Decretales [Decretal] and for this reason are not numbered and catalogued, thus they are extra-vagant, literally meaning to "wander outside". However, extravagante also means extravagant, outrageous, and rare.

The poet that dedicates his work to sor Juana affirms that he wants to praise the Mexican Phoenix. While sor Juana certainly does not deny being the Phoenix, as seen in 
chapter two, she strongly denied being a woman. In fact, the following quatrains are particularly interesting and clear about what it means for her to be a special, rare, and extra-vagant creature. In these quatrains, sor Juana transforms the poem into a monologue that can be imagined as part of a drama, recited in a theatre and addressing an audience. The poem was expected to be a written reply, but in the moment in which sor Juana presents the anonymous poet to her fictitious audience, the register and the style of the reply changes:

\author{
Buscando dice que viene \\ a aquel pájaro que nadie \\ (por más que lo alaben todos) \\ ha sabido a lo que sabe; \\ (p. 130, lines 9-12)
}

The anonymous poet says that he is looking for the bird that, according to sor Juana's text, even if everybody praises it, nobody has ever tasted. As might be expected, this short and literal translation does not adhere to the original meaning. In particular the last line of the stanza has several possible interpretations. "The bird that nobody knows which is its taste" in Spanish can be expressed playing on the verb saber, which means to know, but also [saber $a$ ], meaning to taste of. Therefore, here sor Juana's opening follows the semantic flavor left by the word extravagante that appears at the end of the previous quatrain. The Phoenix is described as a rare bird that nobody has ever met, that nobody has ever tasted and, albeit forcing the grammar a little, nobody knows what the Phoenix knows. The Phoenix - or sor Juana - is a creature that wanders in a space that is withdrawn from the world: the cloister. For this reason, the Phoenix is unreachable yet still, everybody praises it.

Sor Juana insists on this idea of elusiveness of the Phoenix. In fact, in the following lines of the poem (lines 13-32), she describes the art of falconry and underlines 
the superiority of the Phoenix, subtly alluding to the fact that it would never allow itself to be caught. In this sense, the cloister is considered not as a place of confinement, but rather as a space that exceeds reality, and that cannot be caught or approached. Moreover, sor Juana does not forget that the anonymous poet who dedicates the poem to her has come from Europe to find the Mexican Phoenix:

De éste, el pobre caballero dice que viene en alcance, revolviendo las provincias y trasegando los mares; (p. 131, lines 33-36)

The gentleman is characterized as "poor" [pobre] because, as the audience already knows, it is impossible to find or approach that which he seeks. In order to find the Phoenix, the anonymous poet turned the world upside down and decanted the sea [revolviendo las provincias / y trasegando los mares]. According to sor Juana, the actions that the anonymous poet takes - that is to say, to turn the world upside down and decant the sea (in the manner one might decant wine) — are expressed using two peculiar verbs: revolver and trasegar. The peculiarity of these two verbs rests in the numerous possible meanings each can be attributed in Spanish. According to the Diccionario de Autoridades (1737), the verb revolver has eight possible interpretations, seven of which prove interesting to understand the poem because they are all related to the act of "turning". 38 The second verb, trasegar, presents three possible interpretations (Diccionario de Autoridades,

\footnotetext{
${ }^{38}$ These meanings can be briefly summerized as follows: to stir, to shake, to rummage through, to turn around, and to turn on. However, it is important to add some more detail in order to better specify their current meanings and use, together with other meanings that in contemporary language have almost disappeared - also from Spanish. For example, when revolver means "to turn around", it is important to remember that this is an action characterized by a strong feeling of uneasiness and restlessness. Similarly, when it is used as "to turn on", the sense is to turn on somebody with an aggressive attitude. According to the Diccionario de Autoridades (1737), this latter meaning also has a secondary meaning that indicates precisely the action of invading an enemy territory, which leaves open the probability that sor Juana is implicitly criticizing the cruel actions perpetrated by Spaniards and Europeans during the conquest of the Americas and the consequent world changes that followed.
} 
1739): The first "to turn upside down", the second "to shuffle"; the third, "to decant". The closing lines of this stanza, once more, add to the poem more than an atmosphere in which everything is examined in the hunt for something that is impossible to find. The sense of turning something upside down, contained in the verb cited above, leads the poem to express and point to a sort of mundus inversus in which not only is the anonymous poet allowed to go in search of something that cannot be found, but sor Juana can also play freely on this metaphorical association between her and the Phoenix.

Moreover, from this quatrain, a new suggestion emerges: The inversion of the meaning, its "revolution", or in more technical terms, the resorting to the topos of the mundus inversus, also contains a reference to the geographical position from which the poem is written. An explicit mention of the Americas appears within a few quatrains, not merely as a geographical annotation. Indeed, if the Americas represent that part of the world that is inverted (not only geographically, but also morally and ethically), in comparison with the Old World that represents the "right" side of the world (once more, a "rightness" that is not only geographical, but also moral and ethical), it is clear that the whole reply by sor Juana has to be read in this delicate and intriguing context. The Phoenix occupies the precise point in which this inversion takes place; a point that does not belong to any side of the world — neither to the "right" side, nor to the inverted one. This point — an unlocated place—-is where the Phoenix can be found.

The following quatrain offers the (fictitious) audience something more about the route taken by the anonymous poet that arrived in New Spain from Europe:

$$
\begin{aligned}
& \text { que, para hallarlo, de Plinio } \\
& \text { un itinerario trae, } \\
& \text { y un mandamiento de Apolo, } \\
& \text { con las señas de rara avis. } \\
& \text { (p. 131, lines 37-40) }
\end{aligned}
$$


In order to find the Phoenix, the anonymous poet has an itinerary afforded him by the Latin author Pliny the Elder [de Plinio un itinerario trae], who mentioned the Phoenix in his Naturalis Historia (lib. X, chapters 3-5). The poet also follows the instruction of Apollo, who specifies in detail [con las señas]: rara avis. In this quatrain, sor Juana starts to undermine the ultimate metaphysical pillar: the status of presence, understood as one that can be directly experienced. The description of the anonymous poet's journey to find an absent creature, the Phoenix, will prove to be extremely interesting and this narrative has a direct impact on the process of demolishing whatever might be considered as certainty. This process can be read both in terms of the generic tension generated by the baroque atmosphere and its approach to certainty, but also as a particular need of our author to shake the ground upon which the European philosophical and intellectual tradition rests. The question posed in the subsequent quatrains underlines this feeling of unease. Indeed, in this quatrain a surprised sor Juana asks the anonymous poet directly if he is unaware that certain qualities of the Phoenix are an invention of Pliny. The quatrain is composed in a more complex way and introduces an interesting syntactical play in its lines:

¿No echas de ver, peregrino, que el Fénix sin semejante es de Plinio la mentira que de sí misma renace? (p. 131, lines 41-44) 
This quatrain ${ }^{39}$ is an important bridge that connects this first part of sor Juana's reply with the second part that will, in its turn, introduce the reader to the idea of monstrosity that provides the main focus of the second part of the poem. ${ }^{40}$

The peculiar syntactical structure of the question is open to different possible readings. In my interpretation, the relative pronoun que, appearing at the beginning of the last line, almost certainly replaces the word "lie" [mentira] because the pronoun that in English must be the neuter "itself" in both cases, in the original Spanish text agrees with the feminine si misma (herself). If the pronoun had agreed with the noun Phoenix [Fénix], which in Spanish is a masculine noun, it would have been si mismo (himself). As consequence, it cannot be the Phoenix that is described here as able to come back to life, but the lie told by Pliny that is able to regenerate itself. "The lie" here points toward the fact that the Phoenix has no equal and is unique [sin semejante]. The correct interpretation or meaning of the quatrain is not as crucial as the detection of the keywords that carry the meaning of the following lines. Peregrino - the pilgrim — retains a semantic connection, both with the act of wandering, and with the semantic field of the word extravagante. In this quatrain the name of the mysterious rara avis is revealed - that is to say, the Phoenix [Fénix] is named explicitly for the first time: The Phoenix is defined as sin semejante,

\footnotetext{
${ }^{39}$ Margo Glantz (2006) comments on this stanza, saying that the Phoenix is counterposed to another animal, the bat, emphasizing how, on the one hand, the bat is a distortion of the order of creation while, on the other hand, the Phoenix is a metaphorization and an emblem of what is extraordinary: "Al no estar perfectamente delimitadas 'estas alas mal dispuestas', atributos que los diferencian de otros animales, los murciélagos distorsionan el orden de la creación, son monstruos, parecidos al fénix, ave mitológica, producto también de una transformación mental, metaforización y emblema de lo extraordinario" (Glantz, 2006, p. 276).

${ }^{40}$ An interesting insight about the peerlessness of the Phoenix is offered in the introduction of an important essay by Frederick Luciani (2010), entitled Literary Self-Fashioning in Sor Juana Inés de la Cruz. He states: "When the Spanish friar Pedro del Santísimo Sacramento penned the accolade [...] to the Mexican literary nun Sor Juana Inés de la Cruz (1648?- 1695), he indulged a baroque delight in witty panegyric. By emphasizing Sor Juana's peerlessness, he also reflected a trend among her contemporary admirers to represent her in terms of a complicated interplay of 'ones' and 'twos'. She was the Mexican Phoenix, 'sólo semejante a sí misma' [resembling only herself] in the words of another eulogist" (Luciani, 2010, p. 15).
} 
which I translated as "peerless"- a characteristic that underlines once more that the bird is not only rare $[\mathrm{rara}]$, but also unique.

The uniqueness of the Phoenix makes it equally famous in the Americas where, as in Europe, there are many people trying to approach and find this fabulous creature. However, as sor Juana warns: “daca el gallo, toma el gallo, se quedan las plumas en las manos" - the more something is manipulated, and pulled to pieces among the various contenders in a dispute, the less remains of it. Here the bird that is metaphorically manipulated, is "el gallo", the cock. The English translation of this saying comes from the dictionary published in London in 1726 by Captain John Stevens. Under the entry gallo, indeed, it is possible to read: "Prov. Entre daca el gallo y toma el gallo se quedan las plumas en las manos. Whilst they contend for the cock they have only the feathers left in the hand. People contending often pull that to pieces for which they strove" (Stevens, A New Dictionary. Spanish and English and English and Spanish [...], London, 1726).

The meaning of the saying is slightly different from the explanation proposed by the Diccionario de Autoridades (1732), however, both posit the idea that a powerful fixation on something can cause only damage. An interesting fact is how, often in her work, sor Juana states that she can barely tolerate the attention that her reputation garners. Giuseppe Bellini (1987), basing his argument on sor Juana's own words and also on the biography written by Father Diego Calleja in 1700, among other more recent analyses by modern scholars, argues that this intolerance might be the reason why she entered the 
cloister and, more importantly, this intolerance indicates a "revulsion" toward the mundane life (Bellini, 1987, p. 17). ${ }^{41}$

The saying appears quoted in the quatrain, but instead of the cock, the bird that provokes the dispute is the Phoenix:

En fin, hasta aquí es nonada, pues nunca falta quien cante daca el Fénix, toma el Fénix, en cada esquina de la calle. (p. 132, lines 45-48)

In this quatrain sor Juana apparently claims that the marvelous features of the Phoenix, and in particular its capability to come back to life, are merely the trivial inventions of Pliny. ${ }^{42}$ The reason why they are nonada (something trivial) is that, since everyone wants to approach and touch the Phoenix, as the saying claims, the rara avis is reduced to something common, normal, and ordinary. This act — the reduction of the Phoenix to an unexceptional bird - is the core of the structural violence perpetrated by traditional culture upon the Phoenix and, in a figurative sense, upon sor Juana's writings. In other words, sor Juana is blaming the excessive attention paid to her story and life, not because she is shyly avoiding this treatment, but because she perceives it as a threat to her decision to spend her life in the lonely space of the cloister. The isolation that surrounds sor Juana in this poem becomes part of the uniqueness that she possesses-a uniqueness that combines the impossibility of being individuated as a subject; the impossibility to be

\footnotetext{
41 "Conoscendo il carattere di Sor Juana attraverso la sua vicenda conventuale, le prese di posizione dottrinali e soprattutto la Respuesta a Sor Filotea, non sembra indulgere alla fantasia pensare al suo intimo disgusto per il mondo vacuo in cui viveva" (Bellini, 1987, p. 17).

${ }^{42}$ As Jorge García-Ramos Merlo (2020, pp. 43-44) argues in his essay "El mito del Ave Fénix en la poesía barroca novohispana: influencias y relaciones comparadas", in this poem sor Juana proposes an ironic reading of the myth of the Phoenix that starts from claiming its inessentiality and ends with the author that identifies herself with the rara avis. As I wrote above, I do not see a direct and explicit denial of the reality of the Phoenix by sor Juana, but only a doubt radiated over its supposed ability to come back to life. The first line of the stanza introduced above reinforces the idea that the description of the Phoenix proposed by Pliny is a "nonada"- that is to say, "something irrelevant".
} 
identified with a genre or a sex; and the impossibility of being approached, not only because of her uniqueness and absolute, extreme singularity, but also because the cloister is increasingly depicted as a non-place. ${ }^{43}$

Here there is a conceptual bridge between the section of the poem that deals with the rara avis - in which sor Juana introduces the Phoenix, starting from its rarity and insisting on its singularity - and the section about the Phoenix and its relationship with "life death" (discussed in detail in the next section). This conceptual bridge is represented by the word "I". For the reasons explained in the previous chapters about the importance of the presence of "I", this poem introduces another feature to the grammatical agreement of this deep and endlessly complex term: its singularity. If, in the poem Primero Sueño, the "I" provoked a striking intervention of gender since it is accompanied by the feminine form of the adjective "awake" (yo despierta; Cruz, 2018, p. 299), in this poem the grammatical agreement in number (singular) becomes crucial. The "I" is present for the first time in line 53, in which sor Juana is talking about those who call her the Phoenix: "dice que yo soy la Fénix" (Cruz, 2018, p. 132). The absolute and extreme singularity of that "I"- a singularity that underlines an extreme and absolute loneliness - is marked, not only by the grammatical agreement that cannot be other than an agreement in singular, but also by the very meaning of the metaphor of the Phoenix that sor Juana places, not only on the power of rebirth, but on the extravagance, uniqueness, and intangibility of the

\footnotetext{
${ }^{43}$ García-Ramos Merlo (2020, pp. 44-45) comments upon these lines, underlining the extreme uniqueness of the Phoenix as a reference to the extreme freedom of sor Juana. While I agree with this interpretation, which converts the uniqueness into freedom, I am not so sure about the proper use of the term "hermaphrodite" that García-Ramos Merlo (2020, p. 45) uses to remark that sor Juana is also free from any sexual label. Following what sor Juana writes in the poem Respondiendo a un Caballero del Perú, she considers the hermaphrodite as the union of the female and the male sex. Containing the two sexes, in my interpretation, the hermaphrodite is not at all free from any sexual label, and for this reason sor Juana is not comparing herself to this figure. Rather, she compares herself to the Phoenix, which is unique and indeed freed from any genre, so that her sex is also unique and singular, and cannot be thought under existent categories.
} 
legendary creature. Nonetheless, these three features are not independent. Rather, together they constitute its uniqueness - the cause of the extravagance and the intangibility of the Phoenix. The rara avis is rare to the ultimate possible extent: a singularity that is not repeatable and that lives in this eternal moment out of time, and in this exclusive place out of space.

Summarizing, in these initial lines, sor Juana depicts a Phoenix that is impossible to capture, lest it be reduced to its exact opposite - an extraordinary creature reduced to an ordinary bird. The verbs analyzed thus far (revolver and trasegar), as well as the image of the Phoenix pulled apart by various contenders, like the cock in the old Spanish saying "daca el gallo, toma el gallo" that sor Juana quotes in the poem, anchor its depiction to a creature in perpetual motion, impossible to place into a monolithic homogeneous group. In this moment, the Phoenix is still presented as pure existence; one that does not permit any reduction to Being. This means that at this point, the poem presents existence and Being in a powerful opposition. Yet it is precisely after this point that the theme of "life death" enters the scene and, in doing so, problematizes this opposition-something that becomes clear in the next section.

\section{The Phoenix as the Metaphor of "Life Death"}

The identification between sor Juana and the Phoenix becomes clearer and more explicit as the poem progresses. In the passage in which sor Juana declares herself to be the Phoenix, she also declares that it draws no distinction between life and death. The idea of "life death" provides the conceptual link between the question of singularity analyzed in the previous section and the identification of sor Juana with the Phoenix, analyzed in the 
following section. The question of the "life death" of the Phoenix is permeated by the themes of singularity and identification, both of which it permeates in return.

From this point onward in the poem, all references to the Phoenix are metaphorical references to the poet herself. The following quatrains reveal the relationship between sor Juana and the Phoenix:
Lo mejor es que a mí a quien quiere encenizarme, o enfenizarme, supuesto que allá uno y otro se sale; dice que yo soy la Fénix que, burlando las edades, ya se vive, ya se muere, ya se entierra, ya se nace; (p. 132, lines 49-56)

The two quatrains above are inseparable because of their strong syntactical nexus. Indeed, it could be said that they introduce the living heart of the poem. The verb enfenizar is formed according to the same process that formed the verb entarquinar in the poem analyzed in chapter two. The meaning is in line with the verb encenizar and can be translated as transforming something or someone into a Phoenix. Here sor Juana claims that those who identify her as a Phoenix simultaneously consider her able to return to life from death. I would like to underline that this return is a movement that happens not in a linear sense, from one place to another, but rather happens in the same moment and in the same place. Therefore, the Phoenix is not passing from a state of Being to another state of Being (I was that, and now I am this), but rather infringes upon the ontological paradigm of being something. Encenizar and enfenizar, similar to life and death, are not two different sides of the same coin, separated; rather, they are in touch and perfusing themselves, one into the other. The verb salirse (allá uno y otro se sale) indicates that the ashes [cenizas] — the Christian symbol of death—are perfused (encenizar) into the act of coming back to life symbolized by the Phoenix. It is interesting that the Phoenix here 
appears as a verb because it is understood as an active effect rather than a passive point of arrival - since it is an action, it produces something.

This verbal activity, which produces a continuous movement - a perfusion of life into death-creates a composite image of the Phoenix as the embodiment of the movement between the temporal and the spatial: the passage from life to death, and vice versa. However, this moment is not one in which life is added to death. Rather, this moment is formed by "life death" in an indissoluble way. So, the Phoenix is the creature that intersects the space between life (and) death, evading [burlando] both aging and time [las edades]. This image appears more clearly in the next quatrain, in which we read:

la que hace de cuna y tumba
diptongo tan admirable,
que la mece renacida
la que guardó cadáver;
(p. 132, lines 47-60)

The Phoenix transforms both cradle and grave [cuna y tumba] into a diphthong - that is to say, into something inseparable in which the cradle rocks the reborn body [la mece renacida] and the grave saves the body under the form of a corpse [la que guardó cadaver]. The subsequent lines (61-80) repeat this image of a corpse that, in the moment it dies, returns to life. The resurrection of the Phoenix is not simply a comparison with the resurrection of Jesus Christ. Rather, it is an example of that moment (without dimension) in which the two main ontological dimensions (existence and non-existence), marked by the passage from existence (life) to non-existence (death), are inverted and erased.

Yet how to translate and explain to the reader this conflation? To fulfil this necessity, the quatrain formed by lines $73-76$ is interesting because two of the recurrent mythological figures in sor Juana's work appear as protagonists: Atropos and Lachesis, two of the three Moirai who, with Clotho, spin, assign the length, and finally cut the 
thread of life of mortal people. The name of Atropos is interesting because the point of death is indicated with a word that in Greek is formed by two parts: the privative $a$ - and the word tropos, meaning the immutable direction, or the point of no return. This point of no re-turn, embodied by the fate Atropos, is precisely the point that the Phoenix posits in its negative form and sense, or in other words, is a point that instead of leading toward death, leads toward life:

$$
\begin{aligned}
& \text { la que Átropos y Laquesis } \\
& \text { es de su vital estambre, } \\
& \text { pues es la que corta el hilo } \\
& \text { y la que vuelve a enhebrarle, } \\
& \text { (pp. 132-133, lines 73-76) }
\end{aligned}
$$

According to these lines, the two Moiras are combined, their different functions merged into the same action. As a consequence, the thread that Atropos ${ }^{44}$ cuts [la que corta el hilo], is threaded again [la que vuelve a enhebrarle] into the same vital wool ball [su vital estambre] by Lachesis. This miraculous moment, in which life and death are no longer distinguishable from each other, identifies a space that has no dimensions, since there is no distance between the two conditions. As a consequence, the binary system of existing/not existing, but also of being/not being, or of being male/being female, are undermined.

Singularity provides the main theme of lines $81-96$, introduced by a reiteration of the idea that sor Juana does not directly admit being the Phoenix. Rather, once more, she is defined by an external eye that says that she is the Phoenix. In fact, the governing clause is always the quoted line 53: "dice que yo soy la Fénix" (Cruz, 2018, p. 132), or in a strict literal translation into English, "[He] says that I am the Phoenix" (emphasis added). The

\footnotetext{
${ }^{44}$ Sor Juana has a particular affection for the image of the three Moiras. Indeed, in her essay "La narración de (su) mi inclinación: sor Juana por sí misma", Margo Glantz (2006, p. 276) clearly states: "Juana Inés tiene especial predilección por estos míticos tríos femeninos, interminablemente ocupados en tejer y destejer la vida, y de los cuales son muy representativos Láquesis, Cloto y Átropos, las parcas, presentes en varias de sus composiciones líricas, como presagio de la muerte."
} 
question of sex now comes into view, building to a climax that starts in a delicate and almost imperceptible way when the Phoenix agrees in feminine at line 53 (yo soy la Fénix).

In this part of the poem, questions of sex, positionality, and singularity often appear combined into a single metaphor or figuration. Lines 81-84 represent the beginning of this process of combination, here of the question of "life death" and the question of singularity (the latter strictly connected with the idea of sex which, as I showed in the second chapter, is counterposed with the word genre):

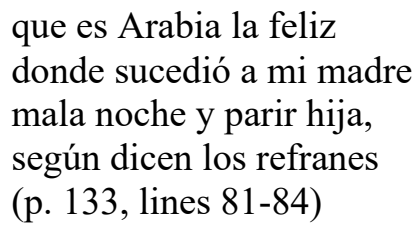

Another Spanish saying is quoted here by sor Juana. Pasar mala noche y parir hija is an expression that alludes to a double disgrace, namely to have a bad night because of childbirth, and because of the birth of a girl instead of a boy. In her annotations to her edition of the poem, Martha Lilia Tenorio explains clearly the meaning of the lines (Cruz, 2018, p. 133) and adds important information about the subsequent quatrain. In fact, sor Juana apparently contradicts herself in the last line where she writes: "según dicen los refranes", using the word "saying" [refrán] in plural [refranes] while she is referring to one saying. Tenorio argues, according to what sor Juana herself clarifies, that the grammatical plural form is used here to maintain the phonetical consonance that the singular version ("según dice el refrán”) would not respect. This grammatical remark is useful because it shows the kind of relationship sor Juana has with writing. Indeed, she uses an unusual rhetorical figure and then immediately explains which rule she is following, thus breaking the distance between the reader and the act of writing. 
Finally, the use of the plural instead of the correct singular form, and the specific reason for doing so, is explained in a quatrain that appears in parentheses:

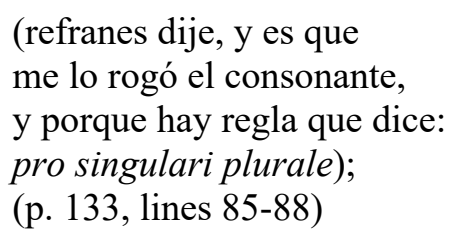

This quatrain contains, not only the justification of the use of the plural ("refranes dije, $y$ es que me lo rogó el consonante"), but also an interesting final line that paradoxically seems so unnecessary that the reader cannot help but pay it more attention. Indeed, so forced into the poem is this justification that sor Juana needs to place it between parentheses. The final line, Pro singulari plurale, in Latin has two possible translations. The first is the regular, and commonly accepted translation: the plural form in place of the singular one. The second is slightly more defensive of singularity: the plural form in defense of the singular one. Here, the idea of a plural form that appears in defense of the singular is fundamental if we are to understand what happens at the end of the first part of the poem. Instead of refusing language, singularity becomes its owner and, in this act of appropriation, language is no longer that which reduces existence to Being, but rather becomes the manner in which existence finds the words to announce itself, producing new, unexpected images - such as the image of the "Fénix que no barbe" (the Phoenix that has no beard), to which I turn in the next section. As a consequence of this revolution of the gender of the Phoenix, a distant and unemotional grammar is revitalized and becomes a living space in which there is more than simple rules mechanically followed and reproduced. Therefore, the struggle of existence (life) against its reduction to a universal definition that transforms it into its opposite (death) is no longer an issue. Rather, there is a "life death" that becomes the productive engine via which language functions beyond the "program of the and and of the is" (Derrida, 2019, p. 6). 
To summarize, in the moment in which the theme of "life death" appears to subvert the rigid binarism of the principle of non-contradiction, singularity no longer appears locked into its existence, deprived of any possibility to go beyond this condition (because it would again be at risk of falling into Being). Rather, it acquires two fundamental characteristics: The first is that underlined by the analysis of the verb enfenizar - a productive verbal activity - and the second is the connection between singular and plural. This productive activity and the connection between singular and plural lead to the peculiar process of identification to which we now turn in the following section.

\section{Que haya Fénix que no barbe: Writing the Phoenix}

The stanzas that conclude the first part of the poem do so via the difficult identification between sor Juana and the Phoenix, specifically how sor Juana removes the obstacle that grammar presents by formulating the gender of the Phoenix as masculine instead (as expected) of female. The grammatical singularity of the Phoenix returns in these stanzas, creating an overlap between the themes of singularity and identity with which sor Juana deals in this part of the poem. The poem unifies into a single metaphor the singular, unique irreplaceability of the Phoenix. It is precisely the irreplaceability of the Phoenix that is the key here, connecting the singularity of the first person of the pronoun "I" $(y o)$ with the fact that this yo is unique, not because of a mere grammatical occurrence, but because it is expressing an absolute singularity.

For expressing this irreplaceability, this singularity is located beyond any possibility of comparison or, in other words, the Phoenix is peerless. Indeed, the stanza that follows, hinges on this idea of peerlessness, not only implicitly, but also by using a 
strategy that appears very often in sor Juana's style in which words do not only mean what they have to, according to the current use of the term, but also the signifier, the written side of the word, intervenes into the semantic aspects, bringing an additional contribution. An example of this procedure is clearly visible when sor Juana writes:

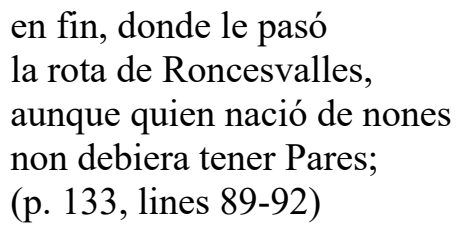

The word game on the term Pares is evident from the comments that appear in the edition of 1951 by Alfonso Méndez Plancarte (Cruz, 1951, p. 440) that annotates the text solving this pun and clarifying that the word game plays on the word "pares", which means peers and paladins. Nonetheless, Méndez Plancare does not connect the pun with the intention of the author to unravel the rigid separation between the levels of language (semantic, grammatical, syntactical, etc.). In the quatrain, sor Juana is alluding to the legendary defeat of Charlemagne in Roncesvalles in 778 as narrated in The Song of Roland. The pun is centered on the word Pares, which in Spanish has several meanings. Charlemagne is presented as peerless, since he was unique and odd, as the number one is ("nació de nones"), since it indicates a single element. For this reason, (he) who is born odd should not have "pares". "Pares" means "even", but is also a reference to the twelve pares, or paladins, who followed Charlemagne on his heroic quests. According to the Diccionario de Autoridades (1737), pares also means placenta [las pares], as well as being the plural form of the word par. Among other, less relevant meanings, it can mean "even numbers", but also "similar" and "pair". The result of this play between "ones" and "twos" is peculiar: On the one hand, the words "odd" and "even" appear both in plural (nones and pares), and it is important to underline that the plural form of the word "odd" [nones] 
partially follows the Latin principle discussed above (pro singulari plurale) because in this case, the odd number is "one". On the other hand, it is possible to interpret the word pares, not only according to the arithmetical meaning, but also in accordance with its other meanings: Who is born unique, does not have comparison, and cannot form part of a pair. Both interpretations function as side aspects of the pun. While "placenta", the third meaning of the term Pares, is not in fact part of the pun, it is also the only term strongly connected with the general meaning of the two quatrains, since both are making reference to the act of giving birth. Following this third meaning, who is born unique has no placenta or, in other words, who is born unique has no descendants. This latter interpretation is a clear anticipation of what sor Juana will write in the second part of the poem about her impossible genealogy.

At this point in the text, sor Juana has to decide whether she wishes to accept the title of "Phoenix" that the anonymous poet has assigned to her. Here, in light of the above analysis, it becomes clear why the reiterated presence of the "yo" that appears several times in the quatrains at lines $93-116$ is so important. In fact, this reiteration serves to underline two aspects of the word "I". While the pronoun points toward a unique and unrepeatable creature - the Phoenix - it is also an encouragement to involve the reader via the use of a pronoun that is at once exclusive in its meaning, and inclusive in its use. As Judith Butler (2015, p. 1) states at the beginning of her book Senses of the Subject, the word "I" does not always say something about "myself": "When I make use of that firstperson pronoun in this context, I am not exactly telling you about myself. Of course, what I have to say has a personal implication, but it operates at a relatively impersonal level." She adds: 
So I do not always encumber the first-person pronoun with scare quotes, but I am letting you know that when I say "I", I mean you, too, and all those who come to use the pronoun or to speak in a language that inflects the first person in a different way. (Butler, 2015, pp. 1-2)

This quote clarifies why I consider the reiteration of the first person as an identification with the Phoenix - an identification that is made less strong, not only by the semantic of the clause (a clause governed by the sentence "he says that"), but also by the very use of a pronoun that is both a grammatical subject and the subject of an object clause simultaneously. This ambivalent role of the word "I" is crucial in understanding the presentation of the Phoenix across all sections of the poem. Sor Juana does indeed not affirm "I am the Phoenix", however, she initially writes: "He says that I am the Phoenix." Proceeding, she asks: “Am I the Phoenix?" Finally, she accepts the epithet without actively asserting her own nature, and without providing a positive reply. I suggest that, in order to achieve this ambivalent result of accepting her nature without affirming it, she uses the ambivalent nature of the word "I" in accordance with the process of the desubstantialization of the subject, as presented in chapter one.

The first quatrain in which the word "I" appears (lines 93-96), concludes the first long clause governed by the verb "to say", conjugated at the third singular person that appears in line 53 (“dice”):

$$
\begin{aligned}
& \text { que yo soy la que andar suele } \\
& \text { en símiles elegantes, } \\
& \text { abultando los renglones } \\
& \text { y engalanando romances. } \\
& \text { (pp. 133-134, lines 93-96) }
\end{aligned}
$$

Briefly, this quatrain concludes a long digression about who sor Juana is said to be (the Phoenix) and the reason why she is compared to it. The reason for the comparison is that, 
like the Phoenix, sor Juana is wandering [suele andar] among "elegant things" [en similes elegantes]. Here, it is important to note that the "elegant things" are a specific reference to the art of poetry: After the second line, we read that the Phoenix is magnifying the lines [abultando los renglones] and decorating romances [engalanando romances]. Of course, it is possible to interpret the quatrain as attributing the role of the poet to sor Juana and/or the Phoenix. Such an interpretation would place specific emphasis on the role of the poet. Sor Juana is not just a writer, an author, or a simple poet; rather, it is the act of writing poems that precisely makes it possible for her to become the Phoenix, and to live beyond her own death. In other words, it is poetry that makes her unique and magnificent like the Phoenix, however, at the same time, she is the one and only who magnifies the lines and decorates the romances by writing them in that specific and unrepeatable form, hence being herself the active subject who writes.

However, the lines can also be interpreted in a different way. This second interpretation moves the subject in the position of the object, meaning sor Juana does not occupy the position of the author, but is herself the topic about which lines and romances are written. In other words, in this different interpretation, she would be an inflection of the subject, rather than the author.

In the next quatrains, sor Juana walks a fine line, recognizing that she might indeed be the Phoenix without stating this explicitly. The style is always strongly ironic and follows the scheme of a comic, dramatic monologue, addressing an imaginary audience:

\footnotetext{
Él lo dice, y de manera eficaz lo persüade, que casi estoy por creerlo, y de afirmarlo por casi. (p. 134, lines 97-100)
} 
The quatrain praises the ability of the anonymous poet to persuade (" $y$ de manera / eficaz lo persüade") everyone, including sor Juana herself, that she is indeed the Phoenix. For this reason, she comes close to believing him and to uttering that sentence: "I am the Phoenix." The reason she ultimately never speaks this sentence, is explained in the following quatrain:

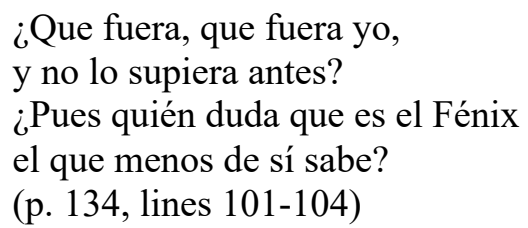

These lines, written in an interrogative form, introduce into the poem a new topic along the question of the singularity of the subject. This new topic is related to the opposition between the determination and affirmation of sex (as the expression of heterogeneity and singularity) and genre (as the expression of the homogeneity of the group): Because sor Juana is unique, she cannot affirm anything about herself. This is a strong refusal of the Cartesian subject, which is considered by dominant Western philosophy also today as the only voice authorized to speak and name its own Being. Here, on the contrary, the most profound example of uniqueness needs another external, heterogeneous voice in order to be named and to know itself.

Returning to the first interpretation of the lines, what is criticized by sor Juana is the act of self-proclamation. Because of the importance that this passage holds, not only in the poem, but also in relation to the contribution I wish to make to subject theory, I would like to elaborate upon this further. The act of self-proclamation is considered impossible and implausible because, as sor Juana writes, it is precisely who "I am" that "I" ignore the most, unless someone else is defining this "I". ${ }^{45}$ In this sense, the subject

45 This intellectual position is aligned with the theories of recognition and self-recognition - theories that Judith Butler traces in her essays written in the first decade of 2000s, and in particular in two books: the 
can be understood, not as a being that is fastened and tied only to itself, but as a being in relation to other beings. For this reason, sor Juana's position differs from the acceptance of the subject as a stable and self-referential entity. Rather, in sor Juana's words, the Phoenix/sor Juana — that is to say, both the author and the "I" (yo) - claims that the subject does not have the ability to know itself. Clearly, this conception of the subject differs completely from the Cartesian subject, which was not only able to make things true only by thinking them, but was also never called into question by another "subject", precisely because it was conceived as absolute. On the contrary, sor Juana's idea of the Phoenix puts forward the idea of a rare and unique creature that lives among other creatures, while the latter are indeed the only subjects that have the ability to know her, and to tell her what she is.

In this part of the poem, the main topic is still the establishment of what entails agreeing only in singular, and at the same time what entails being definable only by an external subject. The reminder of the first issue, concerning "even" and "odd" numbers, is subtle and visible only to the reader able to note that the beginning of the next quatrain contains a rhetorical sematic consonance with line 92: "non debiera tener Pares" (Cruz, 2018, p. 133):

Par Dios, yo lo quiero ser, y pésele a quien pesare; pues de que me queme yo, no es razón que otro se abrase. (p. 134, lines 105-108)

quoted Senses of the Subject (2015) and Sois mon corp, written in co-authorship with Catherine Malabou (Butler \& Malabou, 2010). In the second book, the question of the "I" is approached, taking into consideration the process of the redoubling of the subject, and the Hegelian concept of relation (Zusammenhang), which Butler comments upon with these interesting words: "La chose cesse ensuite d'exister de façon indépendante. Que faut-il entendre précisemént par là? Cela signifie en premier lieu que sa forme déterminée, quelle qu'elle soit, cesse de l'être lorsque la chose se découvre non comme un étant rivé et lié à soi mais comme une instance en relation à d'autres étants rivés et liés à eux-mêmes" (Butler \& Malabou, 2010, p. 63). 
This time, the word pun introduces yet another, new meaning of the word par, previously defined as "even", namely "for", as apparent in the Gallicism "Par Dios", used in old Spanish (an expression equivalent to "By Jove!", or "For God's sake" in English). In this passage, sor Juana declares her willingness to be the Phoenix. Notably, this is a willingness that she did not display when the Peruvian gentleman invited her to become a man (and hence supposedly identifying her as being a woman). The enthusiasm sor Juana expresses when she writes "Par Dios, yo lo quiero ser" is promptly followed by a defense, in which she claims there is no reason why people should take offense of the eventual occurrence that she is indeed the Phoenix. ${ }^{46}$

Why, then, does sor Juana not refuse to be the Phoenix? Why does she not —as might be expected from someone in her position - adhere to the more decent role of a modest nun who should not accept this identification with the rara avis that comes back to life? The answers to these questions appear in the following lines:
Yo no pensaba en tal cosa; mas si él gusta graduarme de Fénix, ¿he de echar yo aqueste honor en la calle? (p. 134, lines 109-112)

Sor Juana is not refusing this role simply because it is an honor that she cannot refuse, but rather, because she has to show respect to the will of the anonymous poet. When all is said and done, sor Juana states, should she refuse this honor, when it is indeed the anonymous poet who wants to give her the status [graduarme] of "Phoenix"? This apparent act of arrogance requires more than just a few quatrains to be dispelled, and

\footnotetext{
${ }^{46}$ Sor Juana plays on the double sense of the verb abrasar, which means both to incinerate and to take offense. This double sense of the verb is understandable because sor Juana makes reference to the ashes of the Phoenix, and to the moment in which she/the Phoenix burns in order to come back to life. The general meaning of the quatrain is that sor Juana wants to be the Phoenix without causing envy (envy is in fact a common theme in many of sor Juana's poems), even if in this case, such envy would be justified by the fact that if sor Juana recognizes that she is the Phoenix, since there exists only one Phoenix, nobody can share this honor with her.
} 
indeed, in the following quatrains that conclude this first section of the poem, the inconvenience (and impossibility) of being recognized as the Phoenix returns once more:

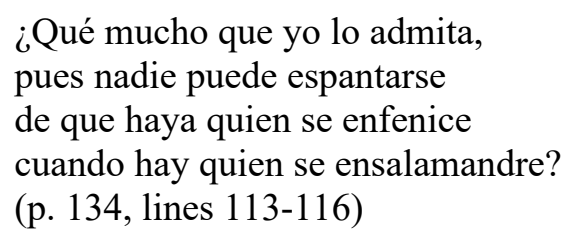

The reply takes the form of a rhetorical question, addressing the audience, saying that there is no reason to be scared by the fact that she is the Phoenix since, as she is transformed into the Phoenix [quien se enfenice], others can be transformed into salamanders [quien se ensalamandre]. Both animals have a peculiar relationship with the element of fire: The Phoenix reemerges from the flames, and the salamander is traditionally represented as not affected by fire. At this point, sor Juana makes a familiar comparison between love and being burnt by fire, using the verb ensalamandrar as the pivot of the quatrain:

$$
\begin{aligned}
& \text { Y de esto segundo, vemos } \\
& \text { cada día los amantes } \\
& \text { al incendio de unos ojos } \\
& \text { consumirse sin quemarse. } \\
& \text { (pp. 134-35, lines 117-120) }
\end{aligned}
$$

However, lovers, even if they are provided with the gift of "consumirse sin quemarse", are not able to come back to life; they merely manage not to die in the flames. This distinction is fundamental, because it differentiates between the two creatures - the salamander and the Phoenix — while simultaneously establishing that the Phoenix is unique, and that it does not form a pair [par] with anyone, whereas salamanders symbolize the condition of being able to love and to be loved in return .

The next quatrain explains something more about the issue of sex, giving the reader a glimpse of what will be stated in the second part of the poem: 
Pues luego no será mucho, ni cosa para culparme, si hay salamandras barbadas que haya Fénix que no barbe. (p. 135, lines 121-124)

Since sor Juana is compared to a Phoenix rather than a salamander, she argues that she cannot be involved in a love relationship, and she is not to be paired up with a similar creature: Because the Phoenix is unique, it has no predetermined companion. Therefore, because of this absence of sexuality, there is no guilt in being the Phoenix, not even for a nun. This quatrain concludes the first section of the poem, and hence I would like to try to isolate the main points that sor Juana reiterates here.

Firstly, we have to remember that the salamander is a feminine noun in Spanish, while the Phoenix is a masculine noun. This may create a problem from the dominant perspective of the Cartesian subject in accepting a unique (male) role, transposing such a famous example of uniqueness and self-reproduction of the singular (which are all typical traits of the ideal Cartesian subject) onto a female embodiment (sor Juana), who speaks in reply to another subject. Moreover, this would suggest a subject that needs an external voice to be defined — one that cannot know itself only by thinking.

Notwithstanding the fact that the Phoenix is indeed a male noun, and a male noun can never agree with feminine, sor Juana continues to say that there would be nothing unusual about having a salamander (feminine noun in Spanish) with a beard, by which she means a virile and male specimen. Similarly, she affirms there would be nothing strange about a Phoenix (masculine noun) without a beard, meaning a non-virile specimen. This passage emphasizes that sor Juana can indeed be the Phoenix, and that the grammatical gender of the noun can be irrelevant, especially in the case of a species comprising only one specimen. 
To summarize, in these lines of the first part of the poem, the question of identification is not approached in order to affirm "what I am" or "what I am not", but rather for the Phoenix/sor Juana to re-appropriate what she is told to be. Sor Juana reappropriates this attribution via an identification with the Phoenix, which re-writes and transforms itself in order to violate the "program of the and and of the is" (Derrida, 2019, p. 6) carried by language. In the preceding section, two characteristics became most evident: the productive verbal activity and plurality. Here, this productivity is expressed as the plurality of writing.

\section{The Monster and the Impossible Genealogy of the Phoenix}

The second part of the poem focuses on the monstrosity of the Phoenix and its impossible genealogy. Indeed, it narrates all the consequences sor Juana has experienced as a result of being compared to the Phoenix. Here, sor Juana imagines being the Phoenix, and at the end of the poem, she also imagines how the Europeans would react if they found out that the Phoenix has been found in a Mexican cloister. While this allegory leads to an image of the Phoenix as a monster, I suggest we must read the word "monster" as pointing not merely toward a creature with unusual or extraordinary features, but also one with a specific semiotic function, namely to indicate, or to deMONSTRate, a sign that functions as a signifier beyond the signified, and for this reason is configurated as an open structure. Consequently, this second part of the poem will be read and interpreted based on the four essays Jacques Derrida dedicated to the word Geschlecht. As will become clear, these essays explain in detail the specific link that the term "monster" maintains with the functioning of the sign. 
The second part of the poem Romance que respondió nuestra poetisa is also an explanation of the reason why the Phoenix cannot have a genealogy, being a unique and singular specimen of a species that begins and ends each time the Phoenix comes back to life. The first stanza of the second part of the poem makes reference to the place where sor Juana was born:

\author{
Quizá por eso nací \\ donde los rayos solares \\ me mirasen de hito en hito, \\ no bizcos, como a otras partes. \\ (p. 135, lines 125-128)
}

This is a place where [donde] the solar beat down upon sor Juana de hito en hito- that is to say, in her entirety instead of obliquely [no bizcos], as it would happen somewhere else [como a otras partes], for example, in the Old World. ${ }^{47}$

In the next quatrain, she expresses an even greater delight, as the rays of the sun are indeed the only limits to her existence:
Lo que me ha dado más gusto es ver que, de aquí adelante, tengo solamente yo de ser todo mi linaje. (p. 135, lines 129-132)

Precisely because of her uniqueness and extreme singularity, it is not only the living space of the Phoenix that is delimited by the sunlight, but the whole "species"- the whole genre/Geschlecht is resting under the rays of the sun for being represented by only one specimen. This is the characteristic of the Phoenix that pleases sor Juana most: not only the possibility of rising from her ashes and coming back to life, but also its independent

\footnotetext{
${ }^{47}$ In the annotations to another text by sor Juana, Alfonso Méndez Plancarte writes that in the seventeenth century, the tropical zone was described as the zone in which the rays of the sun fall perpendicularly to earth and not obliquely, like in Europe, or in other parts of the world (Cruz, 1955, p. 560).
} 
existence. From now on [de aqui en adelante], writes sor Juana, she will be the one and only, unique member of her group. The Phoenix is necessarily both the beginning and the end of the genre: Being the only one of its kind, the Phoenix has no genealogy, and radically refuses to form a group, or to belong to a genre. ${ }^{48}$

The Phoenix/sor Juana that speaks in this second part of the poem presents herself as freed from any ties, starting from the fundamental tie to either life or death.

$$
\begin{aligned}
& \text { ¿Hay cosa como saber } \\
& \text { que ya dependo de nadie, } \\
& \text { que he de morirme y vivirme } \\
& \text { cuando a mí se me antojare; } \\
& \text { (p. 135, lines 133-136) }
\end{aligned}
$$

Indeed, here sor Juana insists that there is no separation between life and death. In the first half of the poem, sor Juana focused on the depiction of the Phoenix as unique, and as both alive and dead at the same time. From this other perspective, however, sor Juana introduces the question of determination and self-determination. Indeed, since for the Phoenix, there is no distance between life and death, she is able to choose freely whether she wants to be alive or dead. Here sor Juana reflects upon the practical consequences of this peculiar status. She starts from the level of being dead and alive, expressed in the reflexive form (morirme, vivirme), ultimately imagining the practical advantage of not having to write a testament. Here, I would like to emphasize the two reflexive verbs morirme and vivirme. Their meanings are strongly related to the lack of a clear opposition between life and death, and hence here sor Juana is demonstrating that, also where language is concerned, she does not perceive there to be a clear difference between the

\footnotetext{
48 In the essay "Mediaciones del yo y monstruosidad: sor Juana o el 'fénix' barroco", David Solodkow (2009) states that in these verses, sor Juana is revising her genealogy to "confess" her uniqueness and her consequent monstrosity. Also in this case, the term "monster" is used to confirm a status of exceptionality that enables sor Juana to write, and for writing to be part of her essence, despite the fact that at the time, women were generally not involved in artistic or creative processes (Solodkow, 2009, p. 152).
} 
two status. Whereas at first sight, the verb morirse has only one meaning, namely "to die", and the verb vivirse does not only mean "to live", but also, and in this case, "to live herself". Actually, going more in detail, the verb morirse indicates the restriction of the movement when a limb "goes dead" and in doing so, removes the distance between life and death. Similarly, the act of vivirse, adopting the meaning of to live oneself, seals the act of living off into oneself, making it inaccessible, similarly to the act of dying. ${ }^{49}$

The lines that follow form a long, interrogative sentence that puts forward the rhetorical question of whether there could be anything better than to be singular and unique, and to represent that "I" (yo) that is metaphorically isolated in a space of absolute freedom, a freedom that is both freedom from the monstrosity of being categorized and from the "monstrasity" (Derrida, 2008, p. 34) of being forced to show itself as part of the category. ${ }^{50}$ In this non-space, what remains of the traditional idea of the subject is one that can choose freely between life and death. The next stanza explores in more depth what it means to the impossibility of having a lineage:
que no soy término ya
de relaciones vulgares,
ni ha de cansarme el pariente
ni molestarme el compadre;
(p. 135, lines137-140)

The Phoenix, of course, is a creature that is not generated by a genealogy, nor does it generate a lineage of its own. The Phoenix does not represent the término, or the end of

\footnotetext{
49 Interestingly, the verb "morirse", according to the Diccionario de Autoridades (1734), has a specific meaning, and has its own entry in the dictionary, rather than appearing as a derivative form of the verb "morir". The meaning of "morirse" is specular to "vivirse", meaning "Entorpecerse o privarse de sentido algún miembro del cuerpo, como si estuviera muerto"—or, in English, "to become dulled, or to be deprived from sensitivity of a limb, as it were dead". Accepting both meanings, as the Geschlecht method would suggest, morirse expresses both an apparent death (since the affected limb is not gone forever); and the very act of dying.

50 The English translators of "Heidegger's Hand (Geschlecht II)" (Derrida, 2008), John P. Leavey Jr. and Elizabeth Rottenberg, decided to translate monstrosite with the term "monstrasity" to translate the idea that monstrosité is "a monstrosity of monstration" (Derrida, 2008, p. 34).
} 
any mundane relationship, imagining the relationship in the form of a rope or a chain. For this reason, the Phoenix is not surrounded by annoying kindred. ${ }^{51}$

Notwithstanding the fact that I translated the word "término" as "end" in the previous sentence, I would like to dedicate a specific paragraph to this term, because it offers an interesting insight about the idea of the limit. Término has three main semantic sets of meanings: The first set points toward the idea of término as the end of something; while the second set relates to the idea of a delimited space. The third and last set of meanings refers to something that is punctual and precise. This latter translation also finds its counterpart in English, translating the word término into the word "term" (See Diccionario de Autoridades, 1739). Interestingly, sor Juana is writing about her own condition as not being the "término" of a relationship (be this relationship a family bond, a sexual relationship, or any other links to the idea of belonging to a group). ${ }^{52}$

This amazing hidden play on the meanings of the word término constitutes a wonderful introduction to the next stanza. Here, as she did in Respondiendo a un Caballero del Perú, sor Juana states that her body is a neutral repository of her soul, without sexual inclinations:

que yo soy toda mi especie y que a nadie he de inclinarme, pues cualquiera debe sólo amar a su semejante; (p. 135, lines 141-144)

\footnotetext{
${ }^{51}$ In their essay "A Life Without and Within: Juana Ramírez / Sor Juana Inés de la Cruz (1648/51-1695)", Amanda Powell and Electa Arenal (1993, p. 68) remark that "her status as a rara avis (strange bird), while setting her apart from others of her sex and class in the public regard, made possible the physical and psychic space in which she thought and wrote. Respect for the exceptionality was in part a reflection of the profound seventeenth-century interest in unusual natural phenomena that viewed artistic talent and intellectual drive in human females as fascinating abnormalities".

${ }^{52}$ Moreover, this independence is reached by occupying a space that is not limited. Indeed, sor Juana uses the word "término" to indicate that the Phoenix is not the "limit", or the end of a mundane relationship, but also, isolating the verse, that the Phoenix is not a limit to itself. In fact, the word "término" has a specific meaning in the field of logic, because it translates into Spanish the Latin expressions terminus ad quem (the limit that indicates the point of arrival toward something leans) and the terminus a quo (the limit that indicates the point of departure from which something starts).
} 
Actually, before expressing the idea that she is not attracted by any other soul or body, she affirms that she is the only member of her species. These lines represent a brief critique of the Platonic theory of love expressed in the dialogue The Symposium (Plato, 2008, p. 23). Here, Plato explains human love via a separation of the soul, generating a constant attraction between the two parts. ${ }^{53}$

The following stanza of the poem is focused again on the dissolution of the space between life and death:

$$
\begin{aligned}
& \text { que al médico no he de ver } \\
& \text { hacer juicio de mi achaque, } \\
& \text { pagándole el que me cure } \\
& \text { tanto como el que me mate; } \\
& \text { (p. 135, lines 145-148) }
\end{aligned}
$$

Here sor Juana simply claims that for the Phoenix, there is no need to visit a doctor that may examine any of her ailments, since the price she would pay in order to be healed, would be the same amount that she would pay to be killed.

The next two stanzas focus on yet another metaphor of the Phoenix: Not only is she the rara avis that puts in crisis the concepts of genre, categories, and life and death; this Phoenix is also an author, or a writer.

$$
\begin{aligned}
& \text { que mi tintero es la hoguera } \\
& \text { donde tengo que quemarme, } \\
& \text { supliendo los algodones } \\
& \text { por aromas orientales; } \\
& \text { (p. 136, lines 149-152) }
\end{aligned}
$$

The act of writing is considered here as the moment in which the passage from life to death takes place. If there is a physical space for this passage, this space has to involve both the idea of presence and absence simultaneously. This space is keenly individuated

\footnotetext{
53 "So saying he proceeded to cut everyone in two, just as people cut up sorb-apples for preserving or slice
} eggs with a hair" (Plato, 2008, p. 23). 
by sor Juana in the act of writing. ${ }^{54}$ Metaphorically, the inkwell becomes a fatal bonfire, in which the Phoenix has to be burned in order to come back to life. In particular, sor Juana here evokes the image of the cotton of the pen that burns and emanates "Oriental scents"- that is to say, the scent of the incense. Specifically, Algodones refers to a seventeenth-century material from which pens were made. Pen, in Spanish, is pluma, which in turn refers both to the "pen" and the "feather" of the Phoenix simultaneously. Indeed, in the next stanza, the first verse introduces exactly this metonymy, in which the Phoenix is depicted while she is writing with her own body:

$$
\begin{aligned}
& \text { que las plumas con que escribo } \\
& \text { son las que al viento se baten, } \\
& \text { no menos para vivirme } \\
& \text { que para resucitarme; } \\
& \text { (p. 136, lines 153-156) }
\end{aligned}
$$

Translating this fundamental quatrain, its general message is that the Phoenix writes with her own feathers - those same feathers that she uses to fly in the wind, to "live herself" [vivirme], and to come back to life. Interestingly, whereas the previous quatrain was centered on the idea of dying (the passage here moved from the cotton of the pen, to the Oriental scents of the funeral), this second half of the diptych focuses on living and rebirth. Both actions - the action of dying and the action of living — are related to the act of writing.

The Phoenix, then, is writing herself. The transformation of sor Juana into the Phoenix can be possible only if sor Juana is willing to transform herself into writing.

\footnotetext{
${ }^{54}$ In her essay “La Celda, el hábito y la evasión epistolar en sor Juana Inés de la Cruz”, Luz Ángela Martínez (2012) claims that this quatrain is also alluding to the double role of the cloister, which is both the place where sor Juana decides to shut herself away, and the place in which she can live, write, and study freely. According to Martínez, the bonfire represents the negative and monstrous aspects of the cloister, while the material (cotton) of the pen represents the freedom offered at the same time by the cloister itself. Martínez (2012, p. 86) calls this double role of the cloister "autoencierro libertario" [liberating self-enclosure]: "Frente a la monstruosidad o la hoguera, la paradoja del 'autoencierro libertario' se presenta como un acto de autodefensa y de huída."
} 
Following the syntax of the lines, these two stanzas continue to express the satisfaction of being a Phoenix, always preceded by the governing clause "Is there anything better than...". Therefore, positing the governing clause next to these stanzas, the conclusion is that there is nothing better than to have an inkwell that is in fact the bonfire in which the Phoenix dies while she is writing; that there is nothing better than to use her own feathered body to write - that is to say, to die, to live, and to come back to life, all in the same space and action.

The following quatrain focuses on the advantages and benefits of not being forced to write a testament, and closes the long interrogative clause. In a certain way, it is possible to consider the testament as a text of rebirth, because it is a text that is written by a person who is alive, and read in the moment of the death of the author. Of course, it is also a text that will ultimately prove completely useless for a Phoenix, as we can read in the stanza:

$$
\begin{aligned}
& \text { que no he de hacer testamento, } \\
& \text { ni cansarme en item máses } \\
& \text { ni inventario, pues yo misma } \\
& \text { he de volver a heredarme? } \\
& \text { (p. 136, lines 157-160) }
\end{aligned}
$$

The advantages of not being forced to write a testament are connected with all the features of the Phoenix that we have encountered thus far: the fact that the Phoenix cannot be married or marry anyone; that she herself constitutes the entirety of her "species"; that for being unique, the Phoenix has no offspring; and lastly, that she is both dead and alive at the same time, and will therefore be the only one to inherit her own legacy.

This section in which the Phoenix ponders whether or not she should write her testament, starts with a depiction of our author, living in joyful isolation in the cloister, where she is completely free - to the extent that even the choice of whether she is alive 
or dead, is hers entirely. Proceeding, the Phoenix rejoices in the fact that her isolation in the cloister also enables her to avoid some other, cumbersome, daily tasks:

\author{
Gracias a Dios que ya no \\ he de moler chocolate, \\ ni me ha de moler a mí \\ quien viniere a visitarme; \\ (p. 136, lines 161-164)
}

In this quatrain, the tone remains the same, and sor Juana/the Phoenix again expresses her gratitude for not being forced to grind [moler] cocoa beans, and for not being "ground" (annoyed) by visitors like cocoa beans. ${ }^{55}$

In the first part of the poem, the decision of the anonymous poet to search for the traces of a nonexistent creature that, even if indeed it did exist, would be impossible to find by definition, is slightly ridiculed. Conversely, this second part plays extensively on the ultimate sense of individuating in sor Juana the embodiment of the Phoenix - an embodiment that she takes seriously, and pushes to its extreme symbolical and practical consequences:

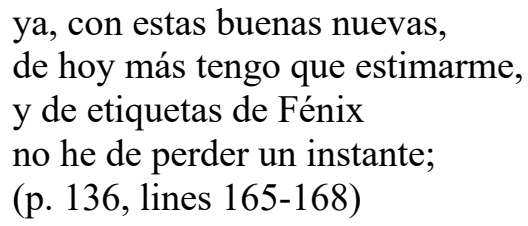

This stanza opens a new section, introducing the effects that being the Phoenix has had on the author. Here, the focus is specifically on the consequences of the potential exposure of the Phoenix to a European audience-if indeed she would not be shut away in the controversial space of the so-called New World. In this context, sor Juana seems to like and appreciate having been identified as the Phoenix. Indeed, in the quatrain, she writes

\footnotetext{
55 The act of grinding chocolate is a very basic and common activity in Mexican cuisine, but it is also
} particularly tough, because the hard cocoa beans need to be crushed to a powder. 
that thanks to this good news [con estas buenas nuevas], she can value herself a little more: Ever since the moment she read the praise of the European gentleman [de hoy más tengo que estimarme], she has been keen not to miss a single moment of the ceremony that identifies and honors her as the Phoenix [y de etiquetas de Fénix / no he de perder un instante]. The long clause ends with the following stanza:

$$
\begin{aligned}
& \text { ni tengo ya de sufrir } \\
& \text { que en mí los poetas hablen, } \\
& \text { ni ha de verme de sus ojos } \\
& \text { el que no me lo pagare. } \\
& \text { (p. 136, lines 169-172) }
\end{aligned}
$$

Here, sor Juana claims that being the Phoenix, she can avoid any suffering derived from the fact that other poets may speak through her voice. She can write freely, quoting other authors. Even more interestingly, she proceeds to suggest that, should anyone want to meet the Phoenix, they should pay to visit her. The next quatrain expresses her surprise when discovering that, presumably, the conquest of the Phoenix had been expected to entail no cost:

$$
\begin{aligned}
& \text { ¡Cómo! ¿Eso se querían, } \\
& \text { tener al Fénix de balde? } \\
& \text { ¿Para qué tengo yo pico } \\
& \text { sino para despicarme? } \\
& \text { (pp. 136-37, lines 173-176) }
\end{aligned}
$$

This stanza opens with a strong expressing of surprise, almost in an offended tone. ¡Cómo! can be translated as an emphatic "What?!”, followed by a rhetoric question in which sor Juana denounces those who may have thought that they could keep this wonderful creature that is the Phoenix for nothing. According to the author, there is indeed a price to pay, should they want to keep the creature. However, this price cannot be expressed in money. Rather, it is constituted by the freedom of the Phoenix to have her revenge, allowing her to speak the truth about them: 
¡Qué dieran los saltimbancos

a poder, por agarrarme

y llevarme, como monstruo,

por esos andurrïales

(p. 137, lines 177-180)

This stanza opens an exclamative clause, comprising three quatrains. The scene in the first stanza quoted above depicts the imaginary kidnapping of the Phoenix by saltimbancos which, as proposed by Electa Arenal and Amanda Powell (Cruz, 1994, p. 179), can literally be translated as "mountebanks". If the mountebanks were to seize and take her, the author suggests, along those "andurriales", they would expose her as a monster. While the word andurriales has been translated as "byroads and lonely places" by Arenal and Powell (Cruz, 1994, p. 179), the actual meaning-which is difficult to place in a poetic translation for rhythmic and metrical reasons - constitutes another blow to the idea of the separation between a supposed Old Catholic, European, morally superior World on the one hand, and a supposedly infidel, American, corrupted New World on the other. Indeed, it is suggested, the mountebanks should take the Phoenix to Europe, here represented specifically by the French and Italian andurriales, a word that means precisely a godforsaken place, or better still, literally, in Spanish, "a place forgotten by God".

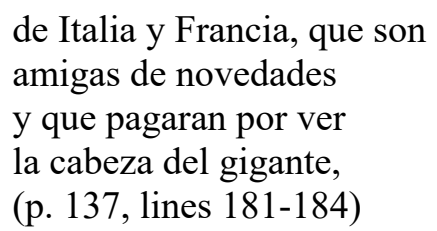

The syntactic period continues in the next quatrain, the second of the triptych, in which a justification is given for why it are precisely the Italian and French places forgotten by God that have been selected for the scene of the kidnapping: Italy and France are "friends of novelties" (translated by Arenal and Powell as "so fond of novelties"; Cruz, 1994, p.179), and they would pay a lot of money to see "the head of the giant" [la cabeza del 
gigante]. In Europe, the Phoenix would be nothing more than a dead monster, exposed by the mountebanks to a curious, almost morbid audience.

This reference to the head of the giant is the first step into the process of the transformation of the Phoenix into a monstrous creature and the play among the different etymological meanings of the Latin root monstr- :

$$
\begin{aligned}
& \text { diciendo: "Quien ver al Fénix } \\
& \text { quisiere, dos cuartos pague, } \\
& \text { que lo muestra maese Pedro } \\
& \text { en la posada de Jaques"! } \\
& \text { (p. 137, lines 185-188) }
\end{aligned}
$$

As if it were a circus performer or a mere circus attraction, ${ }^{56}$ the Phoenix is showed [muestra] in an old inn that is ran by a man called Jaques. While indeed a typical French name, as Martha Lilia Tenorio underlines in her comments on the poem (Cruz, 2018, p. 137), it is also an allusion to el jaque, meaning "a rogue". The show is led by maese Pedro [master Pedro], a name that reminds of Cervantes' maese Pedro-the puppet master in Don Quijote. The reaction of the Phoenix/sor Juana is clear and loud. No puppet master, nor rogues, nor mountebanks are to take advantage of her uniqueness:

\author{
¡Aquesto no! No os veréis \\ en ese Fénix, bergantes; \\ que por eso está encerrado \\ debajo de treinta llaves. \\ (p. 137, lines 189-192)
}

\footnotetext{
${ }^{56}$ Margo Glantz (2006) identifies in these verses the acme of sor Juana's monstrosity. According to Glantz, the verses in which sor Juana describes the eventual kidnapping are taking the metaphor of the Phoenix into the semantic field of the monstrous creatures, rather than the marvelous creatures. This passage, moving from a positive to a negative example, is due to the excessive and almost morbid attention paid to her talents by sor Juana's coeval admirers: "Convertida en Fénix, está en la cima de la monstruosidad. Bien lo entiende ella así, sabe que es mirada como si fuera un bufón, un objeto de circo, el centro de atracción. Se le ha otorgado un lugar especial entre las mujeres, se la ha etiquetado, separado, y el disturbio que su genial inteligencia y su excepcional discreción han provocado puede mantenerse bajo control: se le ha dado un nombre. Sin embargo, la atención que se le presta puede asemejarse, repito, a la que reciben los fenómenos en las ferias o los bufones en la corte" (Glantz, 2006, p. 230).
} 
The quatrain is the ultimate reply by sor Juana to those who ask why she opted for the cloister, rather than to live at court. The arrogant interference of Europe, as it happened with the conquest of the Americas, would deprive the Phoenix of her uniqueness and marvelous aura, monstrada - that is to say, put on display and transformed into a monster-in Jaques' inn. The cloister protects the Phoenix from the kidnapping and at the same time from being reduced to a monster, and in particular to a dead giant. The implication here is that the cloister is a place in which the Phoenix escapes the influences of colonialism.

The last two stanzas are two quatrains dedicated to the valediction of the anonymous poet:

$$
\begin{aligned}
& \text { Y supuesto, caballero, } \\
& \text { que a costa de mil afanes, } \\
& \text { en la invención de la Cruz } \\
& \text { vos la del Fénix hallasteis, } \\
& \text { por modo de privilegio } \\
& \text { de inventor, quiero que nadie } \\
& \text { pueda, sin vuestra licencia, } \\
& \text { a otra cosa compararme. } \\
& \text { (pp. 137-38, lines 193-200) }
\end{aligned}
$$

Here sor Juana states that, indeed, in finding "de la Cruz"- that is, sor Juana Inés de la Cruz - the anonymous poet has found the Phoenix. In this way, sor Juana is accepting the status of Phoenix, but at the same time she is reattributing the privilege of being the Phoenix to the anonymous poet's actions.

\footnotetext{
${ }^{57}$ In an essay published in 1985, entitled "Sor Juana Inés de la Cruz: Reclaiming the Mother Tongue", Electa Arenal (1985, pp. 63-75) claims that the use of the word Phoenix in this poem is a praise as well as a "disparagement". This double interpretation does not affect my analysis, since in both cases, the refusal of the Phoenix to belong to a universal genre is still present in the verses analyzed.
} 


\section{The Sexisting Upheaval of the Phoenix}

I will now combine the act of sexistance, as explored in the previous chapter, with what Derrida (2019, p. 6) defines as "the program of the and and of the is". This program, represented by the Phoenix in sor Juana, emphasizes that the resistance against any sexual identification calls the entire paradigm of patriarchy into question. It does so, not as a mere celebration of diversity, but rather, as Derrida (1995, p. 93) writes in "Choreographies", in terms of "a history of paradoxical laws and non-dialectical discontinuities, a history of absolutely heterogeneous pockets, irreducible particularities, an unheard-of and incalculable sexual differences". This "history" that admits "paradoxical laws", "non-dialectical discontinuities", "absolutely heterogeneous pockets", "irreducible particularities", and "incalculable sexual differences" here becomes the history of the Phoenix, in her constant dance between life and death, as it has been "told" by sor Juana in the poem.

Here, I attempt to establish-in an experimental way-a possible connection between what sor Juana states about the Phoenix on the one hand, and its contribution to the history of "incalculable sexual differences" on the other. Indeed, being unique and without equal, the Phoenix is an example of an "irreducible particularity". In this sense, it can be thought of as an "unheard-of sexual difference": Its difference is "incalculable", since it continues to change sex, from its masculine grammatical gender, to the untold sex of sor Juana.

In my detailed analysis of the poem Romance que respondió nuetra poetisa, I have examined the themes approached by sor Juana: singularity; "life death"; her identification with the Phoenix; and its impossible genealogy. In this final section of the chapter, I 
propose a theoretical elaboration of the elements highlighted during the close reading of the poem. Sor Juana's identification with the rara avis, I suggest, arrives at the construction of a Phoenix (el Fénix) that has no male description nor features, and that becomes the subject of writing. Following this path, there is no rigid opposition between existence (life) and Being (death), but rather, a passage through "life death" that moves from a singularity to its endless re-writing.

What does it mean to write as the Phoenix? The answer to this question points toward an important difference between the Phoenix, which identifies itself through writing, and the concept of "life death" as it has been presented and used by Derrida. This difference is that the Phoenix, transformed into writing, survives the moment of death, but does not overcome it: A cornerstone in Derrida's philosophy is that writing in general, and autobiographical writing in particular (as is the case in sor Juana's poem), are expressions of death, and therefore, in his words, (auto)biographies are "thanatographies" (Derrida, 2019, p. 38). The reason why Derrida connects the process of writing, and in particular the process of writing about oneself, with death, is because he understands writing as something that emerges from our own mortality: In order to survive our death, we need to leave something behind - a trace of our existence (life). From this perspective, writing is the acceptance of the author's death in order to affirm his or her life. In this sense, writing cannot be separated into two different moments: Death, even if it is different from life, constantly accompanies life within writing. Like in sor Juana's Phoenix (as a metaphor of "life death", and thus of writing in the Derridean sense), life cannot be separated from death. The Phoenix is singular and a sexisting, unique creature. The existing Phoenix (that is, the living Phoenix) is inseparable from its male noun el Fénix (the Phoenix that surrenders to the norm and to Being). Sor Juana does not change 
the word's normative grammatical gender, because she needs to underline the apparent contradiction within the Phoenix/writing, as writing contains the engine of "life death". The Phoenix/writing does not overcome the moment of death, because this moment is the fundamental ground upon which it survives.

In his last interview, entitled Learning to Live Finally... The Last Interview, Derrida explains clearly that which I would call the phoenixification of writing: "I live my death in writing" (Derrida, 2007, p. 33). He continues:

The trace I live signifies to me at once my death, either to come or already come upon me, and the hope that this trace survives me. This is not a striving for immortality; it's something structural. I leave a piece of paper behind, I go away, I die: it is impossible to escape this structure, it is the unchanging form of my life. Each time I let something go, each time some trace leaves me, "proceeds" from me, unable to be reappropriated, I live my death in writing. It's the ultimate test: one expropriates oneself without knowing exactly who is being entrusted with what is left behind. (Derrida, 2007, pp. $32-33)$

The main focus of my analysis is the separation between life and death that sor Juana's Phoenix calls into question and shakes at its roots. As observed during the close reading, the theme of "life death" is central to the poem. The strategic theoretical position of "life death" informs a reading of the poem that takes into consideration the whole composition, because it is not possible to extrapolate and decontextualize this theme from the theme of singularity, and the difficulties that the male pronoun causes when it comes to identifying sor Juana with the Phoenix. The Phoenix configures itself as a singularity (rara avis) in movement ("life death"), also between genders/dualities (que haya Féniz que no barbe). 
The idea of singularity that surfaces from the act of positing the theme of "life death" between the theme of singularity and the theme of identification, is that of a singularity in revolt, caught in the moment of its upheaval. This revolt is directed against the "program of the and and of the is" (Derrida, 2019, p. 6).

In this sense, sor Juana distinguishes between the ideas of the Phoenix as existing, and the "Phoenix" as a noun. The first Phoenix (the existing Phoenix) represents something that exists in the sense of exceeding the sphere of Being, while the second "Phoenix" represents a noun that imposes a grammatical norm (singular and masculine). The Phoenix/existing is in revolt and in sexistance against the norm-that is to say, against the Phoenix/noun that imposes the "program of the and and of the $i s$ " (Derrida, 2019 , p. 6). It is a subjectivity in revolt against its own name. The question is whether the norm comes before existence, or whether it is existence (life) that comes before the norm and names itself through a noun. The major transgression enacted by sor Juana is not to name the Phoenix as agreeing with a female grammatical gender, but to claim that the Phoenix not necessarily represents a male being. Indeed, if the grammatical gender functions as a norm also beyond the grammatical level—acquiring an ontological value, defining what something is and what it is not - it would become the instrument by which the homogeneous groups (genres) are constructed.

Following what sor Juana proposes in the poem-writing about a Phoenix that agrees with the male grammatical gender, but has no male features - the grammatical gender is left unmodified. Nonetheless, the sex of the Phoenix is declared to be different from what is expected. In this way, the centrality of "life death" within sor Juana's discourse allows me to show a further complication of the relationship between sex and genre examined in the second chapter. On the one hand, we have the grammatical norm, 
the genre, and sexual categories that harness what is living into the sphere of Being: Only by using the verb "to be" can I express what I am, but in the moment I use the verb "to be" and hence enter into the sphere of Being, I only find death because I do not ex-ist outside of this sphere (I do not exist outside the verb "to be"). On the other hand, we have the freedom expressed by the neologism sexistence (Nancy, 2017) that indicates a sexed life in existence - that is to say, in the space beyond the verb "to be". For this reason, I identify Being with death, and the sexisting Phoenix with "life death". Indeed, existence (i.e. sex or life) does not simply refuse language by transforming into its opposite (i.e. death), classifying it. Rather, existence is able to produce with and by language unscheduled and unexpected moments that oppose the idea of language as an instrument of classification, which would capture existence into the ontological paradigm. Sor Juana's Phoenix can be considered the metaphor for this complication of the relationship between sex and genre, because it has at its heart the engine of "life death".

The Phoenix in sor Juana is completely different from the Hegelian "Phoenix motive" which, as Derrida (2019, p. 43) remarks, is a metaphor for the synthesis that solves the contradiction between positive (life) and negative (death). In fact, in this Hegelian third moment, the synthesis, the negative side (death) disappears, while in sor Juana's Phoenix, death is still present in the metaphor. Making reference to the synthesis of the absolute Idea in the Greater Logic by Hegel, Derrida argues:

At this moment, this ultimate moment, life no longer has any opposition, any opposite; the opposition has taken place within it so that it might reappropriate itself, but life no longer has any other facing it. The is of life is death is of life, being is life, death is unthinkable as something that is. That is, where oppositional logic leads us when the greatest attention is paid to death (as in Hegel): to the suppression of opposition, to its 
sublation in the elevation of one of the terms and the process of its own reappropriation. Life is this reappropriation of being, it is being: only the absolute idea is being, it alone is imperishable life (non-death). (Derrida 2019, p. 4)

The fundamental difference between the Phoenix in Hegel and the Phoenix in sor Juana is that, as Derrida writes, the Phoenix in Hegel arrives only at the end of the dialectical process, while in sor Juana, the Phoenix remains central: It does not represent the end of the discourse, but rather is the engine that sets a new relationship between existence and language in motion. In this way, singularity does not come to signify a pure existence that refuses every linguistic definition, but an existence that reclaims its right to speak and write itself, revolting against the language of an ontology that pretends to define it once and for all. This is what allows sor Juana to create from language an instrument for revolt. According to Derrida (2019, p. 4), the Phoenix in Hegel represents the realization of the "imperishable life (non-death)". Conversely, the Phoenix in sor Juana represents the unsettling power of "life death" that disrupts the "program of the and and of the $i s$ " (Derrida, 2019, p. 6) - that is, a program in which language is nothing more than an instrument to classify reality within the rigid structure of Being, ruled by the principle of non-contradiction. In order to revolt against the norm (genre), the Phoenix/sor Juana does not invent a new language, nor does she upset the grammar. On the contrary, she uses the same language that classifies her, transforming it.

As Judith Butler (1993) explains in Bodies that Matter, grammatical gender is a norm that pre-exists the materiality of sex. This is evident also to sor Juana, who accepts the fact that the Phoenix has to agree with the masculine gender, but nonetheless transforms the sex of the Phoenix by saying that there may exist a Phoenix that "is without beard" ("que haya Fénix que no barbe"; Cruz, 2018, p. 135). In doing so, sor Juana is 
inverting the relationship between the norm, determined by the grammatical gender, and the existence that she names, since the norm is no longer able to impose any sex upon this existence. In other words, this transformation shows that "sex" is separated and independent from the grammatical gender. This freedom to think the grammatical gender as the norm and sex as a free act is important, because in the lines in which sor Juana is commenting upon the fact that the Phoenix has no beard and, therefore, it is not a virile male specimen, she is creating a separation between the grammatical gender and the sex of the existent. In doing so, this separation marks a distance between the noun that imposes the norm, and the existent it names. As a consequence, the existent is not adapting itself to the norm.

At the same time, however, it is important to note this is not just an inversion of the norm. For example, the Phoenix in sor Juana does not repeatedly take up the female grammatical gender either. Instead, there is a refusal of the norm that creates a space between the norm and the existent, demonstrating a clear intention to position the existent outside and beyond the norm. I think this is a significant insight to recover from sor Juana's writings today, because the fact that any norm-including a mostly linguistic one-has the tendency to merely reproduce itself when it is performed yet left unquestioned, remains relevant today. When read through deconstructionist and feminist lenses, sor Juana's writings show how this author can be reborn from the ashes, like the Phoenix, and continues to engage in dialogue with contemporary issues in the debate about sex.

This is why I propose a new reading of sor Juana's texts, in which an upheaval of singularity emerges from within. This suggestion is only new in part, because methodologically speaking, deconstruction has had a long history of entering into 
dialogue with literature in general (see Culler, 1975, 2007), and Hispano-American literature in particular (see Graff Zivin, 2018). The image that epitomizes the refusal of the singularity to enter into a genre is precisely the Phoenix (el Fénix) without its male connotations (the beard). This unconventional male gender that has no male features, yet is not, therefore, automatically female, is the characteristic of the Phoenix that makes it impossible to adapt itself to a homogeneous group. The refusal of the norm allows the Phoenix to regenerate and re-signify itself, because it is not the norm that gives the signified to the singularity, but the singularity that re-signifies the norm in re-writing itself.

The centrality of "life death" in sor Juana's description of the Phoenix creates an image of the Phoenix as a metaphor of endless regeneration. The Phoenix in sor Juana is a figure that connects singularity and writing, thanks to the jointing position of "life death". In sor Juana's work, this connection produces the idea of a singularity that is not isolated into itself - into "what I am". Rather, it is a singularity that escapes Being ("what I $a m$ ") through a continuous movement of regeneration, in which "what I $a m$ " is not erased, but multiplied. In my opinion, the "I" in sor Juana's texts is therefore not an affirmation of a position, but a way to escape this positionality and to dislocate and rewrite herself. When in the text, sor Juana/the Phoenix writes the word "I", this "I" does not have the function of identification, but rather that of a linguistic "shifter".

To have a clearer idea of what a "shifter" is, I quote a passage from the essay "Shifters, Verbal Categories, and the Russian Verb" by Roman Jakobson (1984). Jakobson here returns to the concept of the "shifter", which was first introduced in linguistics by Otto Jespersen, and in semiotics by Charles Peirce. The word "I" is the most famous example of a shifter, since, writes Jakobson: " $I$ means the person uttering $I$ " 
(p. 43). Hence, the meaning of the word "I" is different if "I" am uttering it, than when "you" are (Jakobson, 1984). In the case of the poem by sor Juana, the shifter functions within the same subject - a subject who is speaking and in movement. The "I" who pronounces it, changes each time the "I" is pronounced. The idea of "shifting" from one place to another is a movement that has no direction and no origin: It is not a movement among states of Being, but rather, a manifestation of difference. For this reason, in order to deconstruct the idea of sex and to interpret it as an act that transgresses the sphere of Being, it is necessary to deconstruct the opposition between life (existence) and death (Being). The Phoenix represents this shift that operates the word "I", because when the Phoenix comes back to life, it is not a reincarnation of a precedent Phoenix into a new Phoenix. Rather, it comes back to life in its absolute and singular difference, re-signifying itself each time. In the same way the regeneration of the Phoenix does not constitute a genealogy, it does not constitute a position either, because there is no op-position between the old, dead Phoenix and the new, alive Phoenix. This is another important consequence of the deconstruction of the separation between life (and) death, because it undermines the idea of sex as a position, while sex, as I already highlighted, goes along with the absolute singularity of the Phoenix. The connection between sexistance, understood as a sexed resistance to the norm, and the Phoenix, then, is that the Phoenix is a sexisting creature. The sexistance of the Phoenix is like a dance-a danse macabre of Death and a vital dance of Life that revolutionizes the very concept of position against the Hegelian dialectics that works throughout the re-composition of an opposition (the thesis and the antithesis that recompose their opposition into the synthesis), as Derrida (2019, p. 6) shows. 
Through the Derridean concept of "life death", and via the connection I established with sor Juana's Phoenix, I am able to propose the concept of sexistance as a form of sexual resistance. This resistance leaves open the possibility of sex, however, it is a sex that is not determined or given, since it actively opposes the idea of being a category, or a genre/genus. If sex belongs to life, it is necessary to place all approximations to sex that tend to undermine the meaning of sex in a space of continuous passages - $\mathrm{a}$ state of transition that claims its right to escape definitions or characterizations, or indeed, a space marked by "life death". The cloister, paradoxically, becomes the free space in which sor Juana can avoid having to live her life in a "woman's place", and escapes becoming subject to constant surveillance. As Derrida (1995) writes in "Choreographies": "The most innocent of dances would thwart the assignation $\grave{a}$ residence, escape those residences under surveillance; the dance changes the place and above all changes places" (p. 94). When sor Juana writes that there is no reason to be surprised by the existence of a Phoenix without a beard, she is in fact betraying two grammatical rules: the sex of the Phoenix, which from male becomes female; and the indeterminate article that precedes the Phoenix, as a creature that is unique. In betraying these grammatical rules, sor Juana is dancing; she changes the place, but "above all", she is changing "places" (Derrida, 1995, p. 94) - that is to say, she moves from place to place. In other words, sor Juana's image of the Phoenix erases, once more and once and for all, the dichotomy between existing/not existing in one movement - a change of position that is not a passage, nor a movement from one position to another, or from one state of Being to another state of Being. Rather, it is a dance, a continual revolution, a constant deferring of the own self, in which the dimension of Being loses its substance. 
Therefore, this singularity that phoenixifies itself is moving into a place that is non-central: It is not only marginal, but rather, ex-centrical. This difference between marginality and "ex-centrality" is of pivotal importance to understand that in sor Juana's poem, along the critique of opposition, there is also a radical critique of positionality that conjugates the impossibility to occupy a place with the refusal to be casted "in a realm of radical alterity" (de Lauretis, 1990, p. 117). Here, I am borrowing from Teresa de Lauretis (1990, p. 145) the idea of the "eccentric subject" (de Lauretis, 1990, p. 145). This "eccentric subject" is always in transition (a continuous displacement between "life death") and does not identify itself by naming itself in accordance with the expression of "what I am". Rather, it is a subject that is constantly different from itself or, in other words, other than itself. In the Derridean question of "life death", as well as in the image of sor Juana's Phoenix, the idea of radical alterity emerges or, in Derrida's (2019, p. 4) words, an "other alterity" in which to become the other no longer means to be anymore that and be this, but rather, to go beyond the logic of Being. In the next chapter, I will approach the complex question of belonging in more detail, focusing on the problematic issue of finding a proper literary canon for sor Juana's corpus. 


\section{Fourth Chapter. ;Muere, América atrevida! Untranslatables and}

\section{Borders in Sor Juana's Oeuvre}

\section{Introduction: The Impossible Origin of Sor Juana}

In this chapter I investigate if it is possible to canonize sor Juana's work and, if so, into which canon it might be placed, or if the challenge that sor Juana presents to the principle of non-contradiction prevents her participation in any literary canon-a participation that so often implies national belonging. Via a close reading of the principal works that sor Juana dedicates to America and the critical events of 1492, an anti-essentialist (Sharma, 2015, p. 166) critique of the concepts of nation, coloniality, and (forced) homogeneity will unfold.

Here, I use the term "anti-essentialism" in the manner introduced by Nandita Sharma (2015), whose work focusses on the dualistic and essentialized communities created by the clash between the colonized and the colonizer, and on the risk that emerges as a result. Sharma (2015) captures this risk perfectly in her essay "Strategic Antiessentialism: Decolonizing Decolonization", in which she explains how the essentialist identification of the colonized and the colonizer with a specific racialized representation adopts the same processes of separation effectuated by the colonial system in order to resist colonialism. Following Sharma's perspectives on decolonization and decolonial critique, via the de-essentialization of categories, I will question if sor Juana advocated for Mexican independence because, as was the case with sex, gender, and the subject, the category of "nation" also finds itself in a state of crisis in sor Juana's work. Mexico and America play a pivotal role in sor Juana's corpus. Not only are they geographical expressions; they also already denounce the complex relationship between the different 
faces of a "nation" that, in order to reach a form of unity, needed to erase many voices in the name of homogeneity. In my reading, I also ask how sor Juana's idea of "Mexico" is connected with the idea of singularity.

The answers to these questions are provided in this final chapter, which attempts to unify under the banner of the "national" all of the issues that have come to light thus far. Indeed, without approaching the issue of the subject and subjectivity, and without analyzing the question of sex in sor Juana, this final chapter would be decontextualized and reduced to a mere historiographical account of the Mexican Nation during the seventeenth century from the perspective of a Mexican woman who happens to live in a cloister. If one needed to define sor Juana, one might, in the most spontaneous manner, affirm that she is indeed a woman and a Mexican author, and hence Mexican and women's literature are the two canons in which sor Juana's work might most often be placed. Here, by the term literary canon, I indicate a selection of literary works that respond to a specific general characteristic of the author, or their texts. However, in the previous chapters I demonstrated how sor Juana escapes the canon of women's literature, because she explicitly denies being a woman in the famous line "pues no soy mujer" (Cruz, 2018, p. 121). In this chapter, my focus will be to investigate if the upheaval of singularity that she delineates in her works also problematizes the second definition of her as a Mexican author belonging to the Mexican literary canon.

I suggest that, deprived of its essence, the nationalistic claim by sor Juana represents a critique of the conquest of America and a critique of the monolithic idea of the New World. With this goal in mind, in this chapter I analyze selected passages from two loas (prologues) that precede the auto (play) El Divino Narciso (1691) and the auto dedicated to San Hermenegildo (1692). Additionally, I examine passages from various 
poems and villancicos (carols) in which references to Mexico or America also appear. The reason for this choice rests in the strong connection that these passages and poems have with the topic of the conquista and the expedition of Columbus in 1492 - the year in which the violent conquest of the Americas began. I will interpret this expedition not as a neutral mission, but as a significative yet invasive and abusive intrusion in preHispanic American life. Moreover, I decided to conduct this analysis in order to reveal the difficulties that are encountered when attempting to place sor Juana's oeuvre in the closed space of a literary canon (whether Mexican, or women's literature). Furthermore, I examine possible responses to the urge to classify such an important literary corpus into a canon that responds to a specific theme, not least as sor Juana's corpus demands to be free of any boundary or definition.

Sor Juana Inés de la Cruz lived during the second half of the seventeenth century, experiencing the colonial era as a criolla: a descendant of peninsular Spanish ancestors who were born, or lived, in the Americas. The term, "criollo", rather than defining what sor Juana is, defines what she is not. In a positive sense, "criollo" indicates a person with Spanish parents or ancestors who is born on American soil. However, in a negative sense, one might also say that sor Juana is neither Spanish, mestiza, nor indigenous. From this alone emerges the difficulty any sorjuanist scholar will experience when attempting to place sor Juana's works into a monolithic literary canon (for example woman's literature or Mexican literature). However, this difficulty also opens up new opportunities for the scholar to imagine alternative categorizations that sor Juana herself offers if the reader looks carefully at her writings.

Throughout my readings of sor Juana's corpus, I have demonstrated how her work resists categorization. Her style of writing is multiple, plural, and thus impossible to 
confine to a clearly defined space. The criollo group, as underlined by Octavio Paz (1988), is a subgroup of the so-called novohispano - a group defined more by their absences than presences, and constituted more by what is lacking than what is possessed: "The criollo was and was not Spanish", writes Paz (1988, p. 32). Nonetheless, the criollo became the group protagonist of both the claim and the war for Mexican independence from the Spanish Empire in the nineteenth century. Yet, it is impossible to know if the pride shown by sor Juana when describing America is a declaration of a criollo patriotic feeling (Paz, 1988, p. 36), or if, beyond any question of identity, America becomes an important element in sor Juana's corpus purely because as a space it is featured in so many specific ways. In this chapter, I introduce a perspective on sor Juana's oeuvre that foregrounds the idea of difference instead of thinking about the colonial homogeneity of America from the perspective of the colonial project, which reduces the new world to a wild space that the European gaze can translate and domesticate. My perspective emphasizes and expands upon the condition of singularity and sor Juana's refusal to belong to a sex, defining instead a genre, rather than a gender. This analysis further questions the notions of nation and homeland-especially when that homeland is a colony.

I take as my point of departure a quote from "Strategic Anti-essentialism: Decolonizing Decolonization" by Nandita Sharma, which captures the problem of assigning a category of belonging to sor Juana's corpus:

In the making of a new world, new social bodies and new social imaginaries were made as well. Indeed, many (most?) of the identifications through which people across the world now see themselves would have been unrecognizable prior to 1492 (and, in many cases much later). (Sharma, 2015, p. 165) 
The identities that Sharma describes as non-recognizable "prior to 1492 (and in many cases much later)" are the races, the nations, the "oppositional binaries through which we imagine 'gender'” (Sharma, 2015, p. 165)-homosexuals, heterosexuals, Europeans, Americans, Africans, Asians, and Pacific Islanders. These identities are formed, then, after 1492 and in "many cases" after the era in which sor Juana lived. Moreover, they are formed following an oppositional procedure that does not represent the way in which the concept of "gender" was imagined at that time. For this reason, sor Juana cannot belong to any of these identifications, which also "much later" to 1492, during the seventeenth century, "would have been unrecognizable" (Sharma, 2015, p. 165) to the contemporary reader. We have already seen in chapter one, two, and three how sor Juana negotiates non-heteronormative sexualities and a specific configuration of the subject that is fluid and in a constant state of becoming. Building on these forms, it is now possible to examine the sense in which sor Juana uses terms such as "American", "Mexican", and "Western", and to see whether it is possible, in a contemporary context, to categorize her under such representations. Additionally, it is now possible to examine how the concept of the literary canon, understood here as a space marked and delimited by borders similar to those that delimit the idea of nation, is affected by the challenging "position" that sor Juana occupies. Indeed, sor Juana also challenges this kind of homogeneous group (genre), offering a strenuous resistance_-referred to in the second chapter as sexistance.

In the second half of the seventeenth century, the very ideas of "America" and "1492" possess multiple meanings that demonstrate how geographical and temporal concepts are often impossible to translate. To address this issue, in this chapter I introduce an essay by Emily Apter (2013), Against World Literature: On the Politics of 
Untranslatability. Apter notes the impossibility of translating crucial concepts such as "America", "the West", and especially "1492" to their contemporary meanings. She explains the need to recognize "the importance of non-translation, mistranslation, incomparability and untranslatability" (Apter, 2013, p. 4). According to Apter, to free language from the idea of the existence of a universal truth able to be transposed from one language or idiom to another represents the key to preserving the value of singularity over the hegemony of the politics of translatability. In the specific case of sor Juana's corpus, there is not only an obvious relation with the untranslatability of the text, but also a celebration of grammatical ambiguity as a condition for untranslatability.

As we will see in the next section, the date of "1492" will be the key term used to express the ambiguity of meaning that oscillates between positivity and negativity, and the untranslatability of periodicity (Apter, 2013, p. 69) that resists the homogenizing triumph of the tethering of "literary history to conventions of periodization" (Apter, 2013, p. 69). This non-transferability enables reflection on the "nonplaceability" of both sor Juana's corpus, and of her idea of subjectivity. Ultimately, this idea of "nonplaceability" is resolved at the end of this chapter via the introduction of the Nahuatl word "nepantla", which proves especially interestingly when applied to the work of sor Juana.

\section{Amphiboly and Untranslatability: 1492}

In this chapter I decided to perform a close reading of two loas, preceding the auto El Divino Narciso and the auto El Mártir del Sacramento, San Hermenegildo, respectively. These loas demonstrate the significance of the conquest of Mexico City (loa El Divino Narciso) and of 1492 as a crucial year in the history of "humanity" (from a European perspective; loa El Mártir del Sacramento, San Hermenegildo). Moreover, they show that 
the perception that Columbus' expedition was a heroic deed, was already called into question during sor Juana's lifetime. In this section I will approach the significance of this date, not only as a watershed in Western history, but also as an untranslatable indication of a moment that has many simultaneous, albeit often unrecognized, interpretations.

This reading also questions the white, Christian, and fundamentally European definition of "humanity". Such questioning allows the works on, and references to, America from sor Juana to be placed in a meaningful dialogue with the essays by Sylvia Wynter (1995). Wynter offers a third possible view of 1492 that aims to be a "New World View" according to which the interpretation of 1492 changes. In this seminal text, Wynter tries to overcome the inherent dichotomy present in the interpretation of 1492, calling it "the Janus-faced effects" (Wynter, 1995, p. 14). Here she refers to the dual meaning that can be attributed to this event: positive, a "glorious achievement"; or negative, revealing “interhuman atrocities" (Wynter, 1995, p. 14). Yet, a third view proposed by Wynter (1995) is the "human view" she describes as follows in her "1492: A New World View":

This view is that both the undoubted "glorious achievement" of the processes that led up to Columbus' realization of his long dreamed-of voyage and the equally undoubted horrors that were inflicted by the Spanish conquistadores and settlers upon the indigenous peoples of the Caribbean and the Americas, as well as upon the Africandescended Middle Passages and substitute slave labor force, are to be seen as the effects of Western Europe's epochal shift. (Wynter, 1995, p. 13)

The epochal shift of Western Europe is, according to Wynter (1995, p. 13), the “intellectual revolution of humanism". Rather than simply a number, 1492 is also an event 
that has this Janus-faced quality or, better still, is an amphiboly, an untranslatable term. As Emily Apter (2013) explains, commenting on the recent work edited by Barbara Cassin that explores in a dictionary the untranslatable terms of philosophy (Cassin, 2004), an amphiboly encompasses homonymy and a consequent high level of ambiguity:

Cassin's practice of untranslatability in the Vocabulaire has deepened more recently into a theory of equivocal symptoms in language; historically stigmatized as the mark of radical evil in translation. [...] She suggests that for Aristotle the evil of homonymy is compounded by amphiboly: a form of ambivalent syntax that normalizes the expression of logical fallacies and grammatical anomalies. [...] Amphiboly, as Cassin intimates, makes an error of meaning acceptable even as it arouses conscious suspicion of something off-kilter or terribly wrong within language. (Apter, 2013, pp. 25-26)

Thus, the same signifier, "1492", means (at least) two completely different things, but also other words behave in the same way: "America" and "the West" are words that are not only temporal or geographical; they are also terms that by virtue of their ambiguity and amphiboly undermine what it means to belong to a nation, a period, or an era, and that simultaneously question the colonial system of assimilation, the erasure of difference, and the identification of an indivisible area to a specific intellectual source.

When, in the loa preceding El Divino Narciso, sor Juana claims and revendicates as hers a country that in fact does not (yet) exist (Mexico will only be declared independent from Spain in 1810), her reader witnesses the same process encountered when sor Juana deprived the subject of its solid and steady substance (chapter one), or when she denies belonging to the category of women (chapter two). The problem here is, however, not only a matter of space, or of "where" something is produced, but also a 
matter of "when". From the European perspective, the existence of Mexico is indeed the result of the invasion of a geographical space (the "where"), but also the result of a "discovery" that marked a specific "when" in the history of Europe and, with a completely different outcome, a profound traumatic wound in the history of what is now called the "Americas". This "where" and "when" are the first two "checkpoints" (Apter, 2013) that make it so difficult to place sor Juana into a canon.

Here, I borrow the term "checkpoints" from Apter in order to conceptualize the literary canon as a closed space — one that necessitates checkpoints and borders in order to control what "belongs" and what does "not belong" within it. Indeed, to suggest the existence of these checkpoints and borders problematizes the manner in which texts are deemed worthy (or not). Does sor Juana belong to the European literary canon? Does she belong to the Mexican literary canon? Or does she in fact belong to a generic American canon? The "checkpoints" of the canons to which sor Juana's corpus is generally ascribed (Latin American and Mexican) fail when we acknowledge that the expressions "Mexico" and "America" do not coincide with their contemporary meanings, not least because of the radical changes that have occurred in their geographical and cultural borders. To better understand why, in sor Juana's "conquest" works, there is a substratum of untranslatable concepts, it will prove useful to briefly discuss the events of 1492, in which the invasion of the American continent is just one among several crucial events.

First, to explain why I consider 1492 to be an untranslatable concept, I need to combine the concept of untranslatability proposed by Emily Apter (2013) in Against World Literature: On the Politics of Untranslatability, with the interpretation of the Janus-faced 1492 proposed by Sylvia Wynter in "Columbus and the Poetic of the Propter Nos" (1991); "Unsettling the Coloniality of Being/Power/Truth/Freedom" (2003); "1492 
A New World View" (1995); and in her conversation with Katherine McKittrick, entitled "Unparalleled Catastrophe for Our Species? Or, to Give Humanness a Different Future: Conversations" (2015). These texts will assist in understanding the enormous contribution sor Juana's corpus makes to the process of decolonizing knowledge. If we follow Apter's argument, the untranslatable is a space of resistance:

Words that assign new meanings to old terms, neologisms, names for ideas that are continually re-translated or mistranslated, translations that are obviously incommensurate (as in the use of esprit for "mind" or Geist), these are among the most salient symptoms of the genuine Untranslatable. (Apter, 2013, p. 35)

In Apter's words, not only do we encounter the same untranslatability expressed by the polysemy of the word Geschlecht that permeates this dissertation, but also, upon closer inspection, 1492, "America", and "the West" can be considered "names for ideas that are continually re-translated" (Apter, 2013, p. 35). At the same time, any critique of colonialism cannot disregard what Apter (2013, p. 43) identifies as the "exigencies of a contemporary language politics" that function as "concerns". One of my concerns is precisely to examine the theme of 1492 , and colonial history more broadly, from a perspective that underlines how sor Juana can be read in a manner that encompasses Sylvia Wynter's thoughts on them both. In other words, I need to employ Wynter's third perspective on the events - a perspective that lies beyond simplistic positive/negative interpretations - and connect it with sor Juana's texts in a manner in which both "discovery" and "conquest" are described and perceived differently. In particular, I borrow what Wynter identifies as the repression of the overrepresentation of the white Western "Man": 
A recognition in which we can come to see ourselves as a contemporary, increasingly westernized (in the terms of Man) population, who, as in the case of all other genrespecific human populations, inscript and auto-institute ourselves as human through symbolic, representational process that have, hitherto, included those mechanism of occultation by means of which we have been able to make opaque to ourselves the fact that we so do. (Wynter, 2003, p. 328)

Furthermore, I also need to incorporate into this theoretical approach sor Juana's texts about America, as well as the importance that Wynter (2015, p. 23) assigns to the hybridization between mythoi and bios, and the human understood as homo narrans. Both lead to what she identifies as the "Third Event":

In my own terms, the human is homo narrans. This means that as a species, our hybrid origins only emerged in the wake of that I have come to define over the last decade as the Third Event.[...] I identify the Third Event in Fanonian-adapted terms as the origin of the human as a hybrid-auto-instituting-language-storytelling species: bios/mythoi. (Wynter, 2015, p. 25)

In addition to these initial two co-options outlined above, I need to introduce the "New World View" provoked by 1492, which Wynter defined in 1995 as "human". In sor Juana's work, it becomes evident that the "Western Europe's epochal shift" (which Wynter understands as the cause of the "discovery" of America and the genocides perpetrated by Spanish conquistadores) is still in progress: 
This formulation is the basis of my proposed human view of 1492 . This view is that both the undoubted "glorious achievement" of the processes that led up to Columbus's realization of his long dreamed-of voyage and the equally undoubted horrors that were inflicted by the Spanish conquistadores and settlers upon the indigenous peoples of the Caribbean and the Americas, as well as upon the African-descended Middle Passages and substitute slave labor force, are to be seen as the effects of Western Europe's epochal shift. (Wynter, 1995, p. 13)

Lastly, in my analysis of the loas of sor Juana, I bring into view from Wynter's interpretation of 1492 the key concept of propter nos homines, which she considers of pivotal importance to understanding the attempt to represent a human that is always identical to a hegemonic idea of the human. For this hegemonic human being all the lands were created, so that this genre of the human as "Man" (in Wynter's formulation), which corresponds with the Western European representation, could invade and confiscate all the territories "discovered" during the fifteenth century. In particular, this key concept of propter nos homines is also active in a contemporary context, where an opposition is marked between genetically redeemed and genetically condemned:

The classificatory schema based on the binary opposition of the genetically redeemed and the (supposedly) genetically condemned [...] encodes the criterion of our contemporary model of Man, just as the binary opposition of the habitable/uninhabitable and of the celestial/terrestrial had encoded that of the feudalChristian model. (Wynter, 1991, p. 275) 
On the one hand, 1492 is polysemic and, on the other, it is impossible to translate or displace across centuries and spaces while maintaining the same meaning. The experience of colonization described by sor Juana is both an example of this untranslatability, and simultaneously a proposal to approach the binary colonized/colonizer discourse that Sylvia Wynter (2003, p. 282) also strongly criticizes, differently. In my reading of the loas, and in particular in the close reading of the loa that introduces the auto El Mártir del Sacramento, San Hermenegildo, I also consider 1492 as polysemic instead that connected only to Eurocentric expectations about its meaning in order to interlace the polysemy of 1492 with what Wynter claims about the necessity of thinking beyond oppositional dualities. Although Apter does not directly address the untranslatability of 1492 , I would like to see if what she claims about "the right to the Untranslatable" (Apter, 2013, p.12) can be applied to Sor Juana's work. Sor Juana's corpus here performs a double role: that of an example of the untranslatability of 1492 , but also that of a practical strategy to overcome the two-faced problem it presented.

The main reason I consider 1492 untranslatable, is the powerful impact polysemy had in sor Juana's work. As we will see in the closer engagement with the two loas in the next sections of this chapter, sor Juana distinguishes between the conquest of Mexico in the sixteenth century, and the discovery of the Westward route toward Asia proposed by Columbus in the fifteenth century. The arrival of Columbus in the Americas, initially confused with the Western region of the Asian continent, is not the only event that affected sor Juana's works. Indeed, in the loa that precedes the auto dedicated to San Hermenegildo, she places the exercise of free will by Columbus in relation to the evangelical scene of the Washing of Feet. The concept of free will is the common ground of both the expedition and the Washing of Feet, as it precedes the act of sacrifice: In the 
Christian religion, it is believed that without free will, there cannot exist an act of actual sacrifice. This act of sacrifice is the sacrifice of Christ and the sacrifice of Columbus that sor Juana puts in connection. The act of Columbus is described by sor Juana as a sacrifice because, in my opinion, as Christ moves away from His Father, in the same way Columbus leaves Europe, his fatherland. At the same time, however, the refusal to adhere to the Christian religion and to accept the sovereigns of Spain as legitimate kings (an act encompassed in a specific ritual called Requerimiento ${ }^{58}$ in Spanish) is set against the act of free will and sacrifice. The characters of Occidente and América in the loa to El Divino Narciso act, not as the indigenous population who live through the occupation, without rights, in a no-one's land (terra nullius), but rather as the legitimate sovereigns of a land that sor Juana defines as patria. The question remains open: Was the fall of Tenochtitlan/Mexico City (1521) a consequence of $1492 ?$

To understand why sor Juana holds this double perspective of the conquest and the discovery, it is necessary to further consider 1492 through the eyes of a world that had yet to theorize a colonial consciousness, but that already lived in a colonial situation. In 1492, Europe was experiencing its Renaissance-an extended historical period associated with a flourishing of literature and fine art in many Europeans countries, most notably Italy. According to the Cambridge Companion to Renaissance Philosophy edited by James Hankins (2007, xii), the European Renaissance encompasses the period from the fourteenth to the sixteenth century. Important for our project, examination of the

\footnotetext{
${ }^{58}$ Sylvia Wynter (2003, p. 294) defines the Requerimiento (the Requisition) as follows: "[A] hybridly theologico-juridical document, written in Latin, the Requisition was supposed to be read out to groups of assembled indigenes by a notary who was to accompany any slave-raiding, land-expropriating expedition that sailed from the first settled Caribbean islands to the mainland. This document was intended to ensure that the indigenes in question literally heard the Word of the Christian Gospel, so that they could then be later classified as having refused it, and therefore as Enemies-of-Christ. The document proclaimed to the indigenes that Christ, who was king over the world, had granted this sovereignty to the pope, who had in turn granted the lands of their 'barbarous nations' to the king of Spain, who had sent the expedition members as his emissaries."
} 
chronology that opens Hankins' Companion, specifically with reference to 1492, there is a description of four different events powerful enough to delineate a "before" and "after" within the Renaissance itself. These events interact with, and contribute strongly to, sor Juana's critique of 1492 and the conquest of Tenochtitlan/Mexico City.

Within European history, 1492 is not only the year of the "discovery" (Hankins, 2007, xiii) and conquest of the so-called "New World", but also a complex year that saw several fundamental changes in both the collective European mindset and the approach to major theoretical questions. For example, Hankin (2007, xiii) cites "the death of Lorenzo de' Medici; the expulsion of Jews from Spain; the birth of Juan Luis Vives (d. 1540); [and] Ficino's Latin translation of Plotinus is printed". In addition to Columbus' expedition, these important Renaissance events are all reflected in sor Juana's texts. Indeed, it is possible to argue that the way in which she interprets colonization is heavily influenced by these other events.

Via the events detailed above, sor Juana inherits a peculiar relationship with Greek and Latin mythology — one that forged the allegories of 1492 and 1521 that appear in her works. Indeed, this peculiar relationship proved useful to give back "dignity" to the Aztec and indigenous past of Mexico. However, the hegemonic idea of the human-with the consequent binary opposition between rational/irrational that Wynter (2003, pp. 289-290) discusses in "Unsettling the Coloniality of Being/Power/Truth/Freedom"-represent a damning critique of European society and the genocides. Precisely because the impossibility to translate 1492 rests in its "Janus-faced" nature (Wynter, 1995, p. 14), to translate 1492 would be an act of hegemony. Such an act would entail choosing between "dissident" and "celebrants" (Wynter, 1995, p. 5), refusing the "Third Event" (Wynter, 2015, p. 31) and the possibility of a "third perspective", which Birgit M. Kaiser and 
Kathrin Thiele (2017, p. 404) suggest as a perspective "from which to commemorate, i.e. to give meaning to '1492': an 'ecumenically human', or 'species' view-a perspective decisively beyond humanism, such as 'we' know it".

I would like to conclude this section by suggesting that sor Juana's work indeed provides a further alternative to what Nandita Sharma (2015, p. 167) calls, commenting on Wynter's theories, the dualism of "native and migrants". This alternative is rooted in the fact that sor Juana occupies a "middle ground", albeit one that is fundamentally external to the migrants/native continuum since, being criolla, she is neither. What this "in between" model in the negative ('neither') suggests, is a third (non-conflicting) position-i.e. a third perspective from which to dismantle the concepts of linearity, dualism (led by the principle of non-contradiction), and homogeneity (genre). In the following section, I will present a selection of brief excerpts from some of sor Juana works that will provide further clarity regarding her position toward "America" and "Europe".

\section{America in sor Juana's Works}

When approaching her poetical work, it is clear that sor Juana is completely aware of being an American author, as can be observed in the poem dedicated to "America" quoted in this section. However, it is less easy to affirm her Mexican identity. The latter exists in a convoluted relationship between the criollo people and the indigenous people of Mexico. Indeed, the relationship is even more complex because of the variety of different traditions and cultures that exist in Mexico today, not least the predominance of the Aztec culture (Paz, 1988, p. 36). Sor Juana recognizes the sovereigns of Spain as her monarchs, but she also recognizes the Spaniards as Europeans. What emerges in the work sor Juana dedicated to America and Mexico is precisely this clear awareness of the intrusive and 
abusive role played by Europe. However, there also emerges a dramatic awareness of not being indigenous and hence unable to claim a pure Mexican identity, and of not being European and hence unable to claim a Spanish identity. This schismatic consciousness not only creates a fractured subjectivity, but also a fractured (national) identity. This mechanism is crucial to understanding the complex attitude sor Juana holds toward her place in a space that is always in the middle — not only between the self and the other (as we saw in the first chapter); not only between being female or male (as we saw in the second chapter); not only between being dead or alive (as we saw in the third chapter); but also in political and geographical terms, between (not) being Mexican and (not) being Spanish. There now follows a timely examination of some crucial passages in sor Juana's corpus in which this fracture is expressly articulated, making clear that on the one side of the fracture there is America while, on the other, there is Europe.

If traditionally, America is associated mainly with infidelity toward Christianityan infidelity that justifies the violence perpetrated to conquer its soil (Elliot, 2009, p. 114) — in sor Juana's work it becomes something completely different. In the famous poem dedicated to the Duchess of Aveyro, Aplaude lo mismo que la Fama en la sabiduría sin par de la señora doña María de Guadalupe Alencastre, la única maravilla de nuestros siglos (Cruz, 2018, pp. 100-108), sor Juana describes America as "an isolated pole" (apartado polo) from which she sends her praises to the Duchess (creating a similitude between the Duchess and a deity):

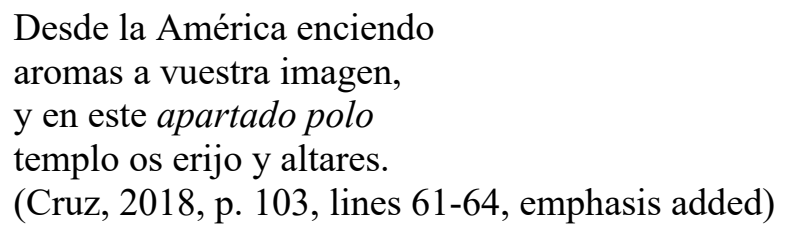

In his annotations to these lines in the first volume of the edition of the complete works by sor Juana, Alfonso Méndez-Plancarte stresses that "polo" means not only "pole" but 
also "clima" (climate; Cruz, 1951, p. 411). Clima is the main meaning of the word "polo", probably because it refers to the belief that the American soil was "corrupted" by its peculiar climate, also corrupting those who live on it (Brading, 2015, p. 104). Nonetheless, I would like to emphasize and add to this annotation that the first attribute that sor Juana identifies in America is its isolation (apartado) from Europe, thereby interrupting any relationship of substantial co-dependance upon European soil as the center of power and the Christian world. It is important here to delineate between "center" and "middle", a distinction that I will analyze further in this chapter. The center and the middle are considered as representing two independent concepts. On the one hand, I consider the middle as a creative and dynamic point that represents an obstacle to the hegemonic power because it subtracts itself from the possibility to be clearly definable. On the other hand, I consider the center as the space occupied by the hegemonic idea of the human as modeled by the West. As Sylvia Wynter suggests in "Unparalleled Catastrophe for Our Species? Or, to Give Humanness a Different Future: Conversations": "[T]he West, over the last five hundred years, has brought the whole human species into its hegemonic, now purely secular (post-monotheistic, post-civic monohumanist, therefore, itself also transumptively liberal monohumanist) model of being human" (McKittrick \& Wynter, 2015, p. 21). If we consider the center as the space of the hegemonic human, sor Juana's work (cited above) necessarily suggests that America's isolation would indicate an exclusion from this model. I adopt this particular perspective here because the insights surrounding 1492 that Sylvia Wynter offers in her essays do not support a specifically Euro-centric viewpoint. While Wynter indeed disrupts the dissidents/celebrants dichotomy of the "discovery" — because, as she writes in "1492: A New World View" (Wynter, 1995, p. 5), the narration of the conquest needs a third point 
of view that cannot simply be reduced to a celebration or a condemnation of the eventthis third perspective can also be traced in the work of sor Juana.

A few stanzas below, in the same poem, sor Juana explicitly praises America and in particular its abundance of goods, showing its central role within the European economy:

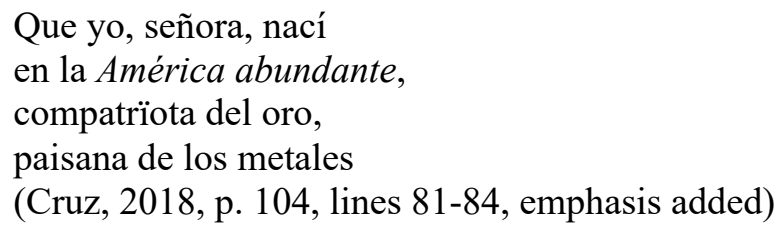

Sor Juana here perceives America as a blessed soil that produces a large amount of goods ("América abundante"), in particular gold and other metals, but also products of the earth that make sor Juana doubtful about the fact that people living in this isolated area are marked by the Original Sin (la común maldición). As with the whole of (Christian) humankind, the inhabitants of the Americas can earn their "daily bread" without effort:

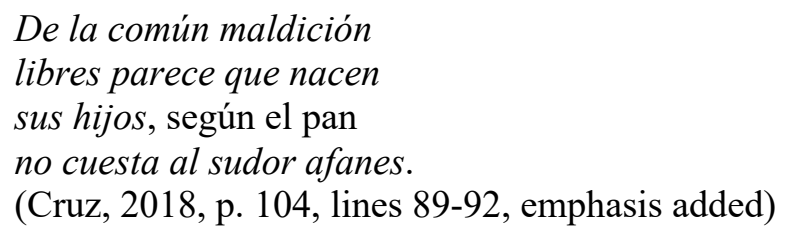

What is opened here, in my opinion, is an important rift in the conviction that America is an "infidel land". This is not only because sor Juana lifts the burden of Original Sin from those who live in the New World, but also because she overturns the idea that America is a land created for the wellbeing of Europeans and therefore a land fully at its disposal. According to David Brading, since the publication of Memorial de las historias del Nuevo Mundo in 1630 by Buenaventura de Salinas y Córdova, and of Crónica del Orden de San Agustín en el Perú (1638) by Antonio de la Calancha, the idea had been circulating that 
it was immoral to enslave the indigenous people of the Americas, since they were considered to be as free as the rest of humankind (Brading, 2015, pp. 84-89).

In other words, in her works, sor Juana distances her idea of America from the allegory circulating in Europe (and represented in the famous engraving by Johannes Stradanus, which depicts America as a naked, vulnerable, but also tempting and lascivious woman who is "conquered" by a European explorer). Indeed, the poem continues with a crucial stanza in which Europe appears as an insatiable predator that drains American resources:

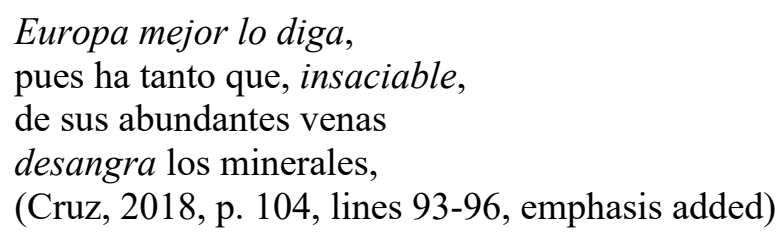

These lines explicitly allude to the predatory attitude of Europe toward the Americas, and the old continent is described as an insatiable creature that bleeds the mines of America as if they were (American) veins.

If, according to sor Juana, America is a land without the Original Sin - a pure Eden - then this posits America at the center and revolutionizes the pivotal idea of the propter nos homines (the Latin expression that indicates that the world has been created for human beings). In this sense, I propose to interpret these lines as those in which sor Juana elevates the inhabitants of Mexico above that of the human, since they live in a state that precedes the moment in which the Original Sin was committed. Once more in Wynter's terms (Mc Kittrick \& Wynter, 2015), a new (but pre-existing) referent- "we” is introduced: the inhabitants of the American continent. Of course, it is not a mere substitution of a precedent "we" to answer the question "who, we?", but a pluralization of referents on the "horizon of humanity" (Mc Kittrick and Wynter, 2015, p. 24). This pluralization weakens the strong and monolithic idea of humanity that the West 
constructed following the conquest of America in 1492, positing instead a single human subject with specific characteristics for which the world was created. The adherence to these characteristics determines whether or not one is able to participate in the "we" that indicates humankind, and therefore whether or not one is granted the privilege of existence or representation.

Sor Juana now shows no mercy as she describes the Europeans, first as Lotus Eaters that forget Europe, and then as a people that, facing American plenty, become contemptuous of their homeland and Gods. This strong critique of the conquest of Mexico plays on an inversion of roles in which Europeans, confronted with a magnificent America, are pushed to betray their Gods, become infidels themselves, and abandon their origins-metaphorically becoming the conquered (by America), rather than the conquerors. Europeans reveal their weakness and aptitude to betray their own faith:

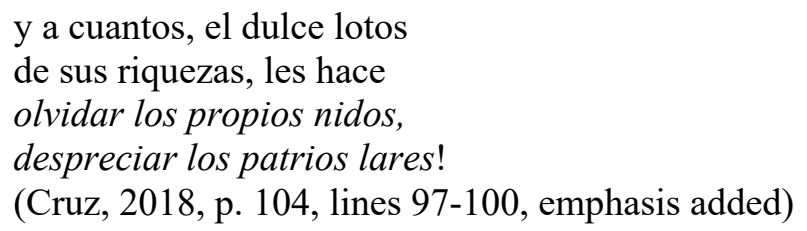

Here, America is confidently described as flourishing and prosperous, a tempting place, impossible to abandon, and even preferred to Europe. ${ }^{59}$ This preference is expressed not only by European mortals, but also by European gods - and specifically in the next quote, by Venus. Sor Juana describes Venus abandoning the beauty of the Mediterranean island of Cyprus for America-a theme that is possible to read into a composition written to

\footnotetext{
${ }^{59}$ This frequent praise to the American territories is accompanied by a precise reference to the Mexican territories with the frequent use of the reference to the "Mexican Eagle"-which remains the symbol of the Mexican Republic today. Generally, the expression "Mexican Eagle" appears in those poems by sor Juana in which there is a strong political element, for example when sor Juana dedicates her poems to the viceroys to celebrate specific occasions such as birthdays or the birth of their heir. I refer in particular here to the introduction of the Baile entitled de un festejo, asistiendo en el Monasterio de S. Jeronimo los Excelentísimos Señores Condes de Paredes, Virrey y Virreina de Méjico; and to the romance Habiéndose ya bautizado su hijo, da la enhorabuena de su nacimiento a la señora virreina.
} 
celebrate the visit of the viceroys of Mexico in the cloister where sor Juana lived (de un festejo, asistiendo en el Monasterio de S. Jerónimo los Excmos. Señores Condes de Paredes, Virrey y Virreina de Méjico; Cruz, 1951, pp. 184-185). The third stanza of the fifth part, the jácara, states:

Hoy, que Venus de sus cisnes desunce el carro triunfal, y por América olvida de Chipre la amenidad; (Cruz, 1951, pp. 184-185, lines 9-12, emphasis added)

Before proceeding with my reading of those verses focused more strongly on the inhabitants of America, rather than on America itself, we need to distinguish the indigenous peoples from Mexican Aztec culture - both present in sor Juana's words, but approached very differently. It remains unclear if sor Juana was aware of the massacres and violence perpetrated during the conquest of Mexico and, if so, whether she condemned them. Nonetheless, Aztec culture is present as a protagonist in many compositions, as well as examples of poems written in Nahuatl. In her poems, she also references the "indios" (Cruz, 2018, p. 158)—references that are not limited only to the highly praised Aztec culture. I find this difference crucial because, in the words of Lugones (1994, p. 463), it "curdles" the idea of America into several different elements (Spaniards, criollos, indios, Aztecs, etc.). ${ }^{60}$ This action reinstates the image of a New World that is responsive to an idea of the "human" that is no longer relative to a strong "in his own image", but rather is pluralized, "curdled", and in which people and idioms are multiple.

\footnotetext{
${ }^{60}$ I use the term "curdle" in accordance with what María Lugones (1994, p. 463) writes in her essay "Purity, Impurity, and Separation": "According to the logic of curdling, the social world is complex and heterogeneous and each person is multiple, nonfragmented, embodied. [...] According to the logic of purity, the social world is both unified and fragmented, homogeneous, hierarchically ordered."
} 
Moreover, the meaning of "American" and "Mexican" have changed over time and today both terms carry different meanings in comparison to the meaning they held in seventeenth-century Spanish. This change is due, not only to the geographical area that these two adjectives represent(ed), but also to their carrying a different semantic aura since, according to Paolo Broggio (2004, p. 17), the New World was inextricably connected with the spiritual conversion to Catholicism of the Spanish Empire. However, as John H. Elliott (2009, p. 193) points out, the relationship between Europe and America during the early modern period was marked by a constant search for some form of balance between similarities and diversities between the two continents - a balance that often involved the principled choice of to whom the status of human was (and is) assigned or denied (Elliott, 2009, p. 195).

A brief pause from our otherwise direct reading of the presence of America in sor Juana's works is now needed, because we need to take a moment to examine the verses in which sor Juana describes her own relationship with Mexico. Bearing in mind that she is a criolla or, in the novohispano meaning of the term, a descendant of Spaniards born on American soil, it remains difficult to establish how deep her roots go in a land that seems to be only a surface upon which sor Juana's genealogy rests. The stratagem that sor Juana uses to establish a connection with Mexican soil is quite interesting. On many occasions, sor Juana affirms that she was born and that she lives in Mexico. She creates a sort of consubstantial relationship with Mexico, for example in the stanza that I presented in the previous chapter during the analysis of Romance que respondió nuestra poetisa, in which sor Juana compares herself to chocolate (an emblematic Mexican product; Cruz, 2018, p. 136):

Gracias a Dios que ya no he de moler chocolate, 
ni me ha de moler a mi

quien viniere a visitarme;

(Cruz, 2018, p. 136, lines 161-164, emphasis added)

Another interesting example of the presence of the American traditions in sor Juana's corpus comes from the romance composed to express gratitude to those European authors who dedicate to her the poems of praise that traditionally formed the preliminares of a publication, and in particular to those authors who wrote the preliminary poems of praise that are to be found in the Segundo volumen, published in 1692 (Cruz, 2018, pp. 156160). In this unfinished poem, the first line of which recites "Cuándo, númenes divinos" and epigraph is Romance en reconocimiento a las inimitables plumas de la Europa, que hicieron maypres sus Obras con sus elogios: que no se halló acabado, sor Juana rhetorically asks which kind of supernatural power could have made her worthy of these:

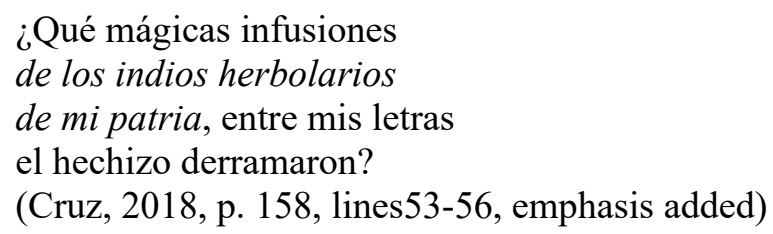

The presence of the "Indian herbalists" can be considered as drawing a partial parallel between sor Juana's writings and the traditions of pre-Hispanic Mexico. What sor Juana wants to create, has in fact a dual effect. On the one hand, she makes a declaration of modesty, claiming that she is not worthy of praise because her work is not purely the result of her own inventiveness, but the result of the intervention of various supernatural elements. On the other hand, among this array of supernatural elements that contribute to the creation of a valued masterpiece, she introduces the magical abilities of the herbalists of "her homeland" (mi patria) and in this way, along with deities from classical Latin and Greek traditions, the "Indian herbalists" make their appearance. Magic also permeates the work of sor Juana, creating yet another example of the consubstantial relationship between Mexico and sor Juana's writings. 
María Dolores Bravo Arriaga (2005) comments on these lines in her essay "Las loas de los autos de sor Juana: los signos de la tolerancia", suggesting that sor Juana simultaneously condenses two different cultures: Pre-Hispanic and European. She writes:

$[\ldots]$ los dos tiempos, los dos espacios y las dos religiones en una convivencia en la que la antigua cultura sigue viva en sus costumbres y en que $[\ldots]$ persiste en su palabra: en las mágicas infusiones que los indios herbolarios entre sus letras derramaron. (Bravo Arriaga, 2005, p. 63)

While I see that Bravo Arriaga's intent is to underline the fact that pre-Hispanic culture survived the violence of the conquest and that also sor Juana stresses this co-existence of two worlds after the colonization of the Americas, for several reasons I do not fully agree with her interpretation. First, it can be shown by looking into the analyzed poems that sor Juana refuses a dualistic separation between a generic and universalistic pre-Hispanic culture and a European Old World. In naming the indios, she differentiates the imperial Aztec culture from indigenous magical rites, and therefore not only is there a co-existing pre-Hispanic and a Hispanic culture, but also several different cultures that merge and diverge in the same geographical space. Thus, I see it better suited to refer in the plural to pre-Hispanic cultures, and to respect the passages in other compositions in which sor Juana references Aztec culture, and other passages in which she references indigenous cultures (even if she fails to name them explicitly). Second, contrary to Bravo Arriaga, I cannot interpret "indios herbolarios" (Indian herbalists) as the subject of the verb "derramaron" (meaning "to spill") in the poem quoted above (Cruz, 2018, p. 158). Instead, I propose that the grammatical construction of the line "de los indios herbolarios" is a possessive phrase, and the subject of the verb "derramaron" is an undetermined 
"they". Thus, the meaning of the stanza changes from a scene in which the indigenous herbalists prepare the potion and they themselves pour this potion over sor Juana's verses, to a different scene in which the potion is indeed prepared by the indigenous herbalists, but someone else is responsible for "adulterating" sor Juana's verses. This indetermination of the subject who commits the action is important, precisely because it absolves the indios from the responsibility of the sinful act of altering the content of sor Juana's poems. In other words, by defining a different "they" - one other than the indios - sor Juana makes a distinction between those who spill the magical potion, and those who made it (the indios). In this way, sor Juana separates the act of making the magical potion from the reprehensible act of corrupting and altering the value of her poems.

Beneath the pluralization of the breadth of Mexican cultures also appears the presence of pre-Hispanic traditions and the Afro-Mexican traditions. This becomes apparent in the many villancicos in which sor Juana writes in Nahuatl, or when her transcriptions - often written in defense of the rights of Afro-Mexicans - exhibit typical Afro-Mexican linguistic patterns and mannerisms. The multilingualism present in sor Juana's work is a significant point of interest, and will be analyzed later in this chapter. Indeed, in addition to Spanish, sor Juana writes in Nahuatl, Latin, Basque and, as briefly touched upon above, in the parlance of Afro-Mexican communities, transcribing their particular way of speaking in order to render and describe a reality that is indeed homogeneous. Instances of these languages, parlances, and jargon can be seen in the negrillos and estribillo of the villancicos para la Asunción composed and published in 1676 (Cruz, 1955, p. 3), which provide an example of seventeenth-century Afro-Mexican parlance (Cruz, 1955, pp. 15-16). Other examples of this parlance are the estribillo 
"Puerto Rico" and the coplas of the villancicos composed for San Pedro Nolasco and dated 1677 (Cruz, 1955, p. 39-40); the estribillo of the villancico composed for the Asunción in 1679 (Cruz, 1955, p. 72-73); and the negro that forms part of the villancico for the celebration of the feast of the Assumption in 1685 (Cruz, 1955, p. 96-97). The presence of the Nahuatl language in sor Juana's literary production is also of substantial interest, not merely as a way to describe the social environment of Mexico City during the seventeenth century, but also demonstrating that sor Juana was in all probability fluent in Nahuatl—a language that does not have the same prestige as Latin did, for example. Here, I would like to quote the introduction to the tocotin (a typical Nahuatl dance) in Nahuatl, which forms part of the villancico dedicated to the feast of Assumption in 1676:

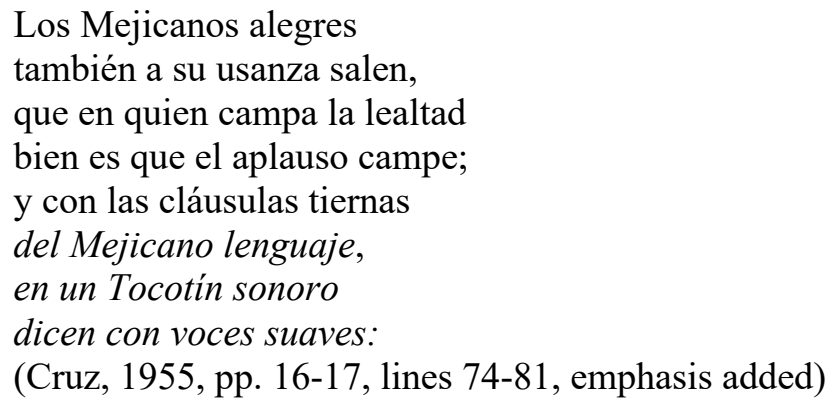

There is of course a specific observation that emerges from the quote, namely, the identification of the "Mexican language" (Mejicano lenguaje) with the Nahuatl language, as if it were representative of all the traditions and cultures then present in Mexico. This is a clear example of the untranslatability of sor Juana's "Mexico" into the modern meaning of the term. Here, with the adjective mejicano [Mexican], sor Juana refers to the Mexica culture that gave its name to the modern nation, but that in the seventeenth century indicated mainly the area of the so-called "Valley of Mexico", rather than the whole territory of the Viceroyalty of New Spain. Nonetheless, despite possessing the ability to write a tocotin in Nahuatl, sor Juana does not identify herself with the Nahuatl and 
Mexican population. At the same time, she does not identify resistance to the Spanish presence in Mexico with a singular, strong, and aggressive imperial indigenous people. For this reason, sor Juana departs from the tendency in criollo literature as described by Octavio Paz (1988, p. 11), namely to establish a cultural continuity between the Aztec culture and the criollo identity.

\section{Loa al Divino Narciso: A Dialogue Between Conquerors and America}

In order to dive even deeper into the discussion of which relationship develops between the conquerors and the conquered peoples of America, I now explore a single work by sor Juana that, by virtue of its form, theme, and length, merits a section of its own. The presence of America in this work unfolds according to a specific perspective on the conquest of Mexico, and therefore reflects on a direct encounter between Aztec and Spanish cultures. This work is the loa (a prologue in form of a play) to the auto sacramental entitled El Divino Narciso (1691). ${ }^{61}$ In this play, sor Juana chooses not to explore the relationship between Europe and America using rhetorical devices to cross the space between the two cultures. Instead, the play is a personification of America, the West, the Christian religion, and religious zeal itself, embodied by characters whose voices allegorically represent the conquest of Mexico City- the ancient Tenochtitlanin 1521 . The work could also be characterized as a sort of mise en abyme of the history of the conquest of Mexico City and, as such, it deserves particular attention in order to evidence the peculiarities of the text.

${ }^{61}$ According to Alfonso Méndez-Plancarte (Cruz, 1955, p. 503), who comments on this loa in his edition of complete works by sor Juana, a loa was a brief stage play of introduction and prologue to a main play, rather like a comedy or an auto sacramental. In this introductory play, the principal characters and topic of the main play were presented, as well as the occasion for which the play was performed. 
María Dolores Bravo Arriaga (2005, p. 57) underlines an important feature of sor Juana's loas and autos, namely the fusion of the pre-Cortesian Aztec theatrical tradition with the Spanish tradition strongly influenced by the plays by Calderón. In fact, the importance of the loa that precedes the auto El divino Narciso hinges on the presence of a specific character: América, a female character who embodies the voice of America. According to Paola Lizana Miranda (2019), the depiction of América in the loa represents an inversion of the common imaginary of the Americas developed in the sixteenth and seventeenth centuries. Contrary to previous examples of the presence of America in sor Juana's poems, here, America does not express its variety of languages and cultures, but is identified specifically with Aztec culture and religion.

As Lizana Miranda (2019) underlines in her essay "La poética o retórica subalterna en la loa El Divino Narciso de Sor Juana Inés de la Cruz" ("The Subaltern Poetic or Rhetoric in the Loa El Divino Narciso by Sor Juana Inés De La Cruz”), América wears a traditional dress instead of being naked or represented in the European clothes of Latin and Greek antiquity, thus demanding equal dignity be acknowledged between European and American antiquity (Lizana Miranda, 2019, p. 48). Indeed, the introductory description of the first scene of the loa reads: "Sale el Occidente, Indio galán, con corona, y la América, a su lado, de India bizarra: con mantas y cupiles, al modo que se canta el Tocotín" (Cruz, 1955, p. 3). This introduction emphasizes the fact that América is "India bizarra: con mantas y cupiles": América is a woman dressed elegantly with mantle and huipil (a traditional Mexican garment), and is thus expressly not a naked territory, as Europeans seemed to believe before venturing into its interior. Simultaneously, other indios are dancing the tocotin, a traditional dance that entered the canon of baroque music composed in New Spain. On the other side, seated next to América, there is another 
personification of the New World - the West, called Occidente. Both characters have two European counterparts: a woman, Religión, the personification of Christianity; and a man, Celo, the personification of Christian religious zeal. In this opening scene, there are only Aztec and American protagonists on stage. My interpretation of the play is that it narrates history specifically from the American perspective. In the first scene, the American characters are living peacefully, celebrating their rites, while only later do the Europeans characters make their violent entrance.

Another important element worthy of note is that contrary to what might be expected, the female characters, América and Religión, embody the positive intellectual values of reason. Furthermore, as Lizana Miranda (2019, p. 38) argues in her reading of sor Juana's loa, América and Religión are especially interesting because they do not respect the general tendency in narratives of the conquering of the Americas to always represent America as naked, irrational, and uncivilized. In sor Juana's words, the traditions and the religion of America are as antique and noteworthy as European traditions. In fact, the loa opens with a celebration of the old and noble Mexican lineage made by another crucial character of the piece, the Music-Música:

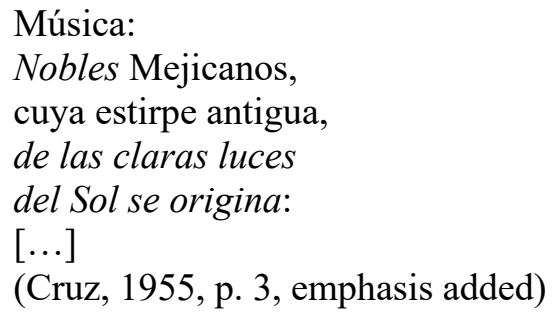

In these lines, the origins of Mexican nobility are attributed to the light of the sun, and in the subsequent lines (below), Música describes the occasion of the gathering: the pagan celebration of the God of Seeds - the deity that ensures abundance and prosperity to the American territories by fertilizing them: 


\author{
Música: \\ Y pues la abundancia \\ de nuestras provincias \\ se Le debe al que es \\ Quien las fertiliza \\ [...] \\ (Cruz, 1955, p. 3, emphasis added)
}

Música is chanting the praise to the Mexican people and to the God of Seeds, describing the ritual that they are about to guide, while Occidente (the West) and América (America) take their seats. ${ }^{62}$

Following once more the work of Lizanda Miranda (2019, p. 48), Religión, despite being a woman and despite the fact that América should be the epitome of savagery, is depicted as noble, as gifted with reason to the extent that she can engage in a direct dialogue with the Christian religion. América's opening line is a polysemic " $Y$ con razón", which can be interpreted as "with reason", understood as the capability of the mind, and as "righteous":
América:
Y con razón, pues es solo
el que nuestra Monarquía sustenta, pues la abundancia
de los frutos se Le aplica; y como éste es el mayor beneficio, en quien se cifran todos los otros, pues lo es el de conservar la vida, como el mayor Lo estimamos:
$[\ldots]$
(Cruz, 1955, p. 5, emphasis added)

América replies to Occidente with the expression " $y$ con razón", but she is also claiming that above all the goods produced by the God of Seeds, the most important one is life.

\footnotetext{
${ }^{62}$ According to the annotations by Alfonso Méndez-Plancarte, the ritual is the Teocualo, a Mexica ritual in which God is metaphorically eaten - an action that creates an interesting parallel between Mexican preHispanic religion and Christianity, to which sor Juana draws our attention (Cruz, 1955, 503; Lizana Miranda, 2019, 45).
} 
This is the first reference to the violence perpetrated by the conquistadores - able only to invade and destroy the land without respect, rather than "conquering" it by using the virtue of Reason (Lizana Miranda, 2019, p. 51).

In the middle of the celebration of the God of Seeds, sor Juana describes the entrance of Religión dressed like a Spanish lady, and Celo dressed like a Spanish captain-“sospechosamente semejante a Cortés" (Glantz, 2006, p. 475)—with Spanish soldiers following behind. ${ }^{63}$ Celo (representing religious zeal) is not a positive character. He is violent and often addressed as "barbarous", uncivilized, and irrational:

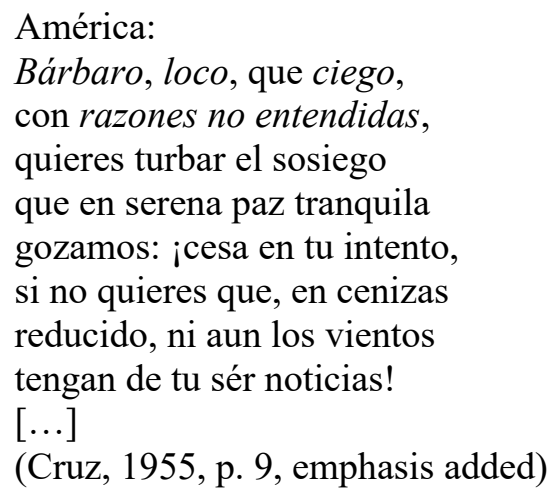

The entrance of Celo is of pivotal importance if we are to fully understand his role. The aggressive male European soldier has no American counterpart but, according to Margo Glantz (2006), finds a solid ally in the Christian Religion (Religión): Occidente and América, with all their indigenous subjects, have to be converted to Christianity or they will be punished by death (Glantz, 2006, p. 475). Here the ambivalence exhibited by Religión is fundamental. If we were to build a list of the characters in the play, from the most, to the least irrational (and therefore from the more civilized to the more uncivilized), Christianity would occupy second (or perhaps third) place, first place being occupied by the actual heroine of the loa: América. Reading further, at the end of the

63 "Suspiciously similar to Cortés" (translation mine). 
second scene, there is the outbreak of the war against América and Occidente-a fight that reveals, according to Margo Glantz (2006, p. 472), an allegorical transfiguration of the history of the conquest of México that sor Juana knows from the documents of Torquemada and his Monarquía Indiana (1615). Moreover, as noted by María Dolores Bravo Arriaga (2005, p. 60), the clash is not between two cultures: Rather, as the names of the characters express, on the one hand we have two conceptual and theological allegories (Zeal and Religion) while, on the other, they are two spatial allegories (the West and America). This has to be understood, not as an emptying of the space of the New World from any critical or intellectual capability, but, as Margo Glantz (2006, p. 482) underlines, as part of the attempt to exorcize the indigenous world of sin, giving back to the Aztec religion the same dignity afforded to Christianity.

Moving forward, Celo and his army attack Occidente and América, interrupting the religious ceremony. América and Occidente appear shocked by the guns and other weapons they have never encountered before. Expressing their dismay, they ask:

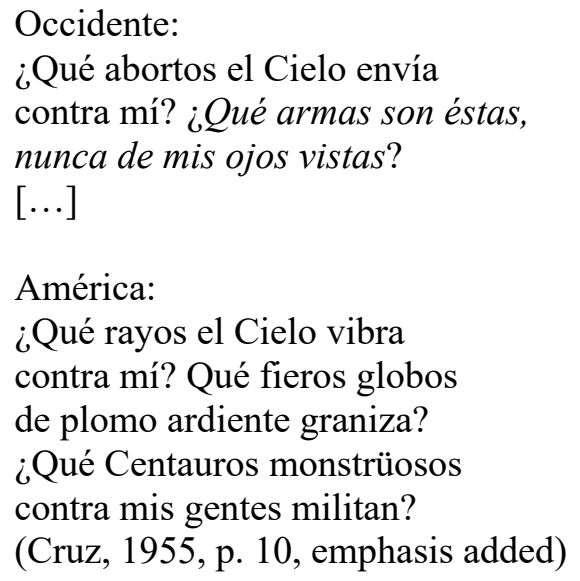

Here, I would like to emphasize how sor Juana describes the violent attitude of the Spanish soldiers, since, as we read in the third scene, after the war, Occidente and América claim that only the physical strength of Celo and Religión could subjugate them, 
not their reason. Thus, Religión needs to intervene with an imperative "Ríndete" [surrender]:

\author{
Religión: \\ ¡Ríndete, altivo Occidente! \\ Occidente: \\ Ya es preciso que me rinda \\ tu valor, no tu razón. \\ Celo: \\ ¡Muere, América atrevida! \\ (Cruz, 1955, p. 11, emphasis added)
}

These lines reveal once more the core argument of the loa, summarized by Margo Glantz (2006, pp. 476-48) in two crucial concepts: sacrifice and free will. Occidente sacrifices himself because the reasons to surrender offered by Religión are not sufficient to justify capitulation. However, a twist in the plot occurs and Religión stops Celo as he is about to kill América and Occidente. The virtue of Reason triumphs and following the clash, in the fourth scene, there is a peaceful dialogue in which the truth - namely that the God of Religión and the God of Seeds venerated by Occidente and América have a lot in common - is demonstrated. This latter point shows how the pre-Hispanic and European traditions are comparable and similar-so similar in fact, that in the penultimate (fourth) scene, there is a long dialogue in which América and Occidente "accept" being conquered by the arguments proposed by Religión:

Religión:

Espera, que aquésta no es fuerza, sino caricia.

¿Qué Dios es ése que adoras?

(Cruz, 1955, p. 12, emphasis added)

A little further on, Religión affirms:

Religión:

De Pablo con la doctrina 


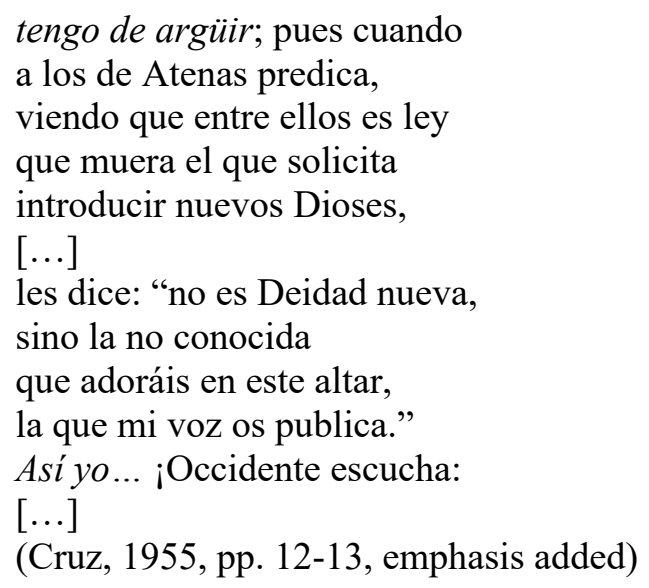

Inspired by St. Paul, Religión decides to convince Occidente and América that her God is an unknown God they already praise. The last scene is a joyful ending in which the auto is introduced as an allegory of Christian Mysteries. However, there is a final, explicit, and very interesting reference to Mexico. Indeed, in a dialogue between Celo and Religión, the reader discovers that the play will be performed in Madrid:

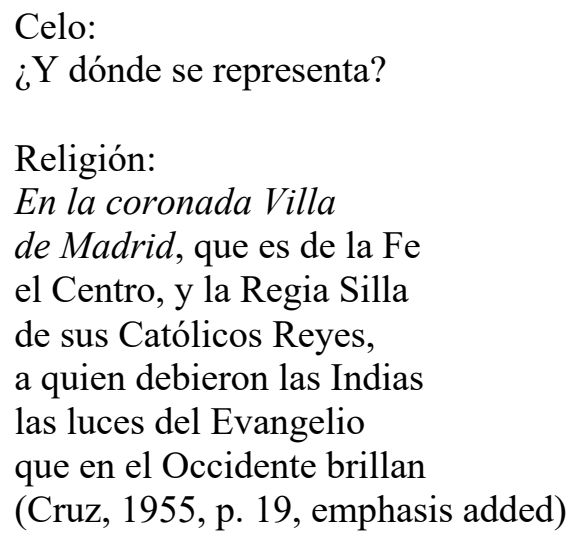

It is interesting to note that, once more, Mexico appears as a culturally independent country with a long history and its own traditions. The only thing that is introduced by (the Catholic) Religión and, in its own particular way, by Celo, is the name and the liturgies to praise the true God and His Gospel (Evangelio). In particular, when Celo asks where the auto will be performed, Religión answers that it will be performed in Madrid, a city described by Religión as the cradle of Christianity ("[...] Madrid, que es de la Fe 
el Centro [...]"; Cruz, 1955, p. 19). Evidently, Religión has a somewhat hyperbolic idea of Spain, compared to Rome, because it is described as the country that brought the Gospel to the "New World". There are two subtle messages hidden in these lines. First, following Lizana Miranda (2019, p. 39), there is no clear revindication of a criollo claim for independence in this loa, however, as also Miranda remarks, other scholars, such as Carmela Zanelli (1994), believe that the separation that sor Juana implies between Spain and her homeland (mi patria) is, in fact, a strategy to identify a difference that may indeed constitute grounds for independence. What is of most relevance here is not only the pride that sor Juana shows in describing pre-Hispanic culture, but also the words of disdain Celo utters when he discovers that a work written in Mexico will be performed in Madrid:

Celo:

¿Pues no ves la impropiedad de que en Méjico se escriba $\mathrm{y}$ en Madrid se represente? (Cruz, 1955, p. 19)

The answer provided by Religión reminds the reader that the work is composed as a commission ${ }^{64}$ and thus is not the product of a subject who independently produces (in this case) her own discourse:
Religión:
¿Pues es cosa nunca vista que se haga una cosa en una parte, porque en otra sirva? Demás de que el escribirlo no fue idea antojadiza, sino debida obediencia que aun a lo imposible aspira. Con que su obra, aunque sea rústica y poco pulida, de la obediencia es efecto, no parto de la osadía. (Cruz, 1955, p. 19, emphasis added)

${ }^{64}$ As with El Neptuno Alegórico analyzed in the first chapter, or the poems that reply to the Peruvian gentleman and the anonymous poet "recently arrived in New Spain" analyzed in the second and third chapters of this dissertation. 
The loa ultimately ends with a choral laud to God that assumes the name of the God of the Seeds, Dios de las semillas. It is important how this loa defines the relationship between the protagonists of the conquest because it underlines certain peculiarities, such as the role of the female characters, that might be less expected in a text written by a Catholic nun.

In summary, there are some interesting terms in this particular work by sor Juana to which I would like to draw attention, namely "West" (Occidente); "America" (América); and "homeland" (patria). I would like to emphasize some concepts, such as the idea of the conquest of the Americas and the difference between the violent use of strength perpetrated by Celo (Religious Zeal), opposed to the rational and benevolent strategy of convincement through the religious truth carried by Religión (Christianity). Running through all of these words, terms, and concepts is a unifying, common question: "Is it possible to translate 1492?" My thesis is that, upon the impossibility of translating this date, also depends the impossibility of translating the various terms and concepts indicated above, and ultimately, the impossible to place sor Juana in a singular canon, literary tradition, or national literary production — in short, to explain why it is impossible to place sor Juana in any singular homogeneous group or genre.

In the loa, sor Juana does not challenge the morphology of the play, respecting the common structure of a loa. Nonetheless, the argument of the text can be categorized under a plurality of genres. The loa that introduces El Divino Narciso is a captivating play in which many different "places" and voices make clear that sor Juana writes from a site that is not easy to identify: First, the play has been composed in the Americas, but performed in Madrid, interfering with a clear position into a colonial literary canon. Second, it has been written by a criollo author, but none of the voices of the play 
personifies explicitly a criollo embodiment of Mexican patriotism ante litteram, interfering with a possible categorization of the play into the criollo literature. Third, while the female characters are depicted as rational and opposed to the disruptive attitude of the male characters, especially European Religious Zeal, nonetheless, this interpretation is not enough to clearly state that the feminist literary canon is the only possible and adequate canon into which the loa can be placed. Sor Juana's position toward women's rights has always been characterized by several ambiguities, for example, here there are no "women", but female characters that are allegories for a continent and a religion.

\section{Loa of the Auto Dedicated to San Hermenegildo: The Conquest of America in sor}

\section{Juana's Work}

In order to follow this thread running through sor Juana's work related to the topic of the conquest, I will introduce another loa in which there appears a clear reference to the conquest: the loa to the auto titled El mártir del sacramento, San Hermenegildo (1692). The reason why it is necessary to move the analysis to this text, is that it represents the "prequel" to the expedition by Columbus and the conquest of Mexico. Here, sor Juana is approaching the theme of the expedition from a particular perspective that makes the topic of the play difficult to grasp at a first sight, but is also deeply connected with the reason why I consider the events of 1492 as untranslatable. This perspective is marked by an idea of "sacrifice" that undermines the whole experience of the conquest and its justification. Who is the real actor of this sacrifice? Is it Columbus, who decided to trespass beyond the ends of the known world? Or the peoples who see their land devastated by the European invasion? Was the American soil made to be exploited by the 
conquerors? Or, on the contrary, was this land not created for the hegemonic idea of humankind, but did it — and still has — a dignity of its own? The key to answering these questions is well hidden by sor Juana under a complex analysis of the free will. Because, the ultimate questions should be: Who is acting according to his or her free will? Who is suffering because of the misinterpretation of this "free will"?

Going to the general topic of the loa that introduces the auto El Mártir del Sacramento, the main theme of the text is the expedition of Columbus. It is interesting to see how sor Juana deals with the topic and with the act of trespass indicated by The Pillars of Hercules (the pillars that flank the Strait of Gibraltar) which, in the ancient vision of the world, marked the end of Christendom and Providence. How does sor Juana position herself with regard to the dual interpretations that generally characterize 1492-among those who interpret this event as an achievement, or among those who interpret it as a catastrophe? As I will show in this section, here too, sor Juana demonstrates her ability to find a third way - albeit one that would be invisible without the precedent reading of the loa to El Divino Narciso.

The characters of this loa are three students, named Estudiante 1, Estudiante 2, and Estudiante 3. Alongside the students, we find Colón (Columbus) with his soldiers, Hércules (the Greek mythological hero with his soldiers), and two musical choirs. Summarizing the plot, in the first scene a theological dialogue takes place between Estudiante 1 and Estudiante $2 .{ }^{65}$ Here, I would like to emphasize that the first two scenes are focused on a specific theological debate that locates the work in its own context and

\footnotetext{
${ }^{65}$ The fact that sor Juana can write as a student of logic and theology, even if she cannot be a student of logic or theology (because at the time, women were banned from any academic study, especially theology) is a clear demonstration that she was able to join any academic debate. Indeed, also in the second scene, the students are debating the "fineza" of Christ, a dispute that sor Juana also approaches in the famous letter quoted in the second chapter, entitled Carta Atenagórica or, more aptly: Crisis sobre un sermón.
} 
time. This detail is important because in the third scene, we move back in time to the place of the Pillars of Hercules that mark the outer limits of the Christian lands. As Giuseppe Bellini (1964, p. 163) underlines in his essay L'opera letteraria di Sor Juana Inés de la Cruz, sor Juana, almost cinematographically, creates a daring narrative flashback in which the audience of the loa can assist in the placement of the pillars.

Nonetheless, the third scene begins with the three students, Hercules, and his soldiers. The students hear the voices of Hercules' soldiers celebrating the placing of the pillars:

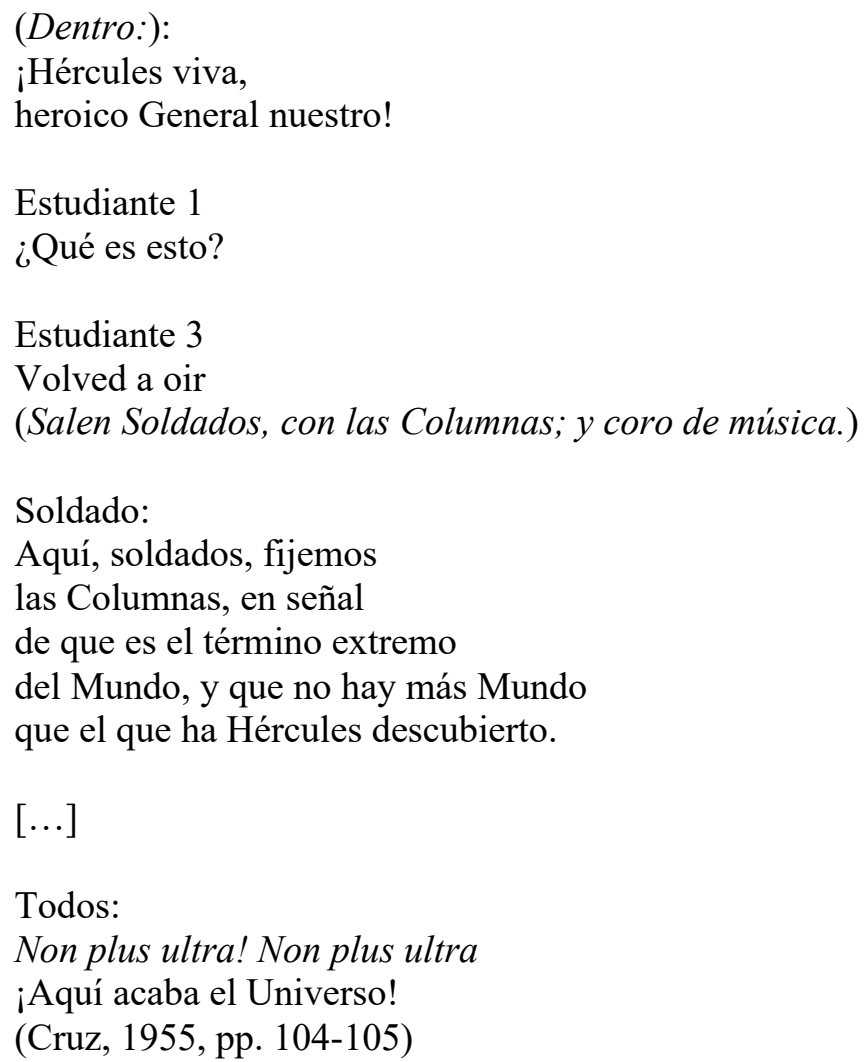

These lines establish both goal and imperative via the inscription non plus ultra [nothing more beyond] which, according to legend, was carved into the columns. The Pillars of Hercules indicate the end of the world and constitute the (Western) limit of the modern world. This limit, which Columbus exceeds with his mission, not only represents a 
material trespassing of a border, but also, according to María Dolores Bravo Arriaga (2005, p. 58), in the loa by sor Juana, the triumph of tradition over authority. This is a very interesting reading, not least because it coherently connects this loa with the loa to the El Divino Narciso. Both works in fact praise the act of free will over (any) law-a free will that, in both cases, results in a sacrifice in order not to surrender to an irrational world or mindset. This warning refers, not only to the backwardness of the European world before the mission of Columbus, but, as we know after the loa analyzed in the previous section, also to the colonial mindset, here considered as irrational, as embodied by the character of religious zeal. The Latin locution non plus ultra [nothing more beyond] is transformed by Columbus into plus ultra [further beyond], which also became the motto of the Spanish sovereigns after 1492. According to Sylvia Wynter (2003, p. 277), the opening toward the unknown world that lies beyond the Pillars of Hercules on which the Latin locution "non plus ultra" was carved, became a possibility thanks to the mission of Columbus and the "de-supernaturalization of its matrix mode of being human" (Wynter, 2003, p. 302) proposed by the Renaissance.

I would like to place this discourse, not only on the level of the free will exercised by Columbus, but also on the stronger and more powerful level as a critique of the idea that America is a land at the disposal of Europeans. In doing so, I connect sor Juana's poems about America (as analyzed above) with the concept of propter nos as examined by Sylvia Wynter in her analysis of 1492 — specifically in her essay "Columbus and the Poetics of the Propter Nos" (Wynter, 1991), written on the occasion of the centennial of the mission of Columbus. According to Wynter, in the times of Columbus, the whole Christian community was convinced that the world was created for us (propter nos, in Latin) in the same manner that the sacrifice of Christ was made to save the Christian 
community (again, the sacrifice would have been made for $u s$ ), meaning that nonChristians were considered idolators and for this reason "legitimately expropriable" (Wynter, 1991, p. 259). The “we", or the nos, coincides, also in Wynter's estimation, with a self-made Christian subject who excludes the idolators from its representation and identification.

The idea of the sacrifice made for us (propter nos) provides a link between the action of Columbus and the Last Supper of Christ, in which Jesus preannounces his sacrifice to the disciples (and, in particular, sor Juana focuses on the moment of the Washing of the Feet). Both sacrifices are connected with water, according to sor Juana, and they are the prelude to the incoming of something greater: an unknown world, in the case of Columbus (which, according to Columbus, was made for us, propter nos); and the Eucharist Communion, in the case of the Last Supper (a sacrifice made for us, propter nos). This argument proposed by sor Juana is helpful to pin down the fact that the land conquered by Spanish conquerors was not made for them.

What is interesting here is the way in which, despite of the propter nos poetics based on the fact that the land discovered was uninhabited and uninhabitable, according to Wynter (1991, pp. 252-54), Columbus' expedition reconfigures both the Christian hegemonic political ethic and its humanism. Returning to the loa, the unknown world here is described, not as unhabitable, but as an already habited place. This becomes very clear when Colón in scene $\mathrm{V}$ in the middle of the loa affirms:

Colón:

¡Más Mundos hay, más Imperios, que tus armas avasallen y sujeten tus alientos! ¡Sál de aquel pasado error, que tus Antiguos tuvieron, de que el término del Mundo 


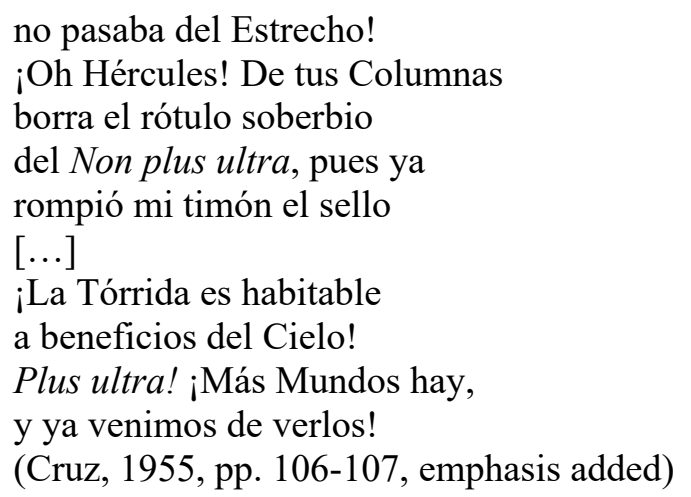

Thus, what we can read here is that Columbus' expedition is expected, not only to challenge the orthodoxy, but also to claim a new route to India for economic purposes. Sor Juana is already aware of what he will discover: Not only a new route to the East, but a whole (new) Western world that in sor Juana's opinion (one made clear in the preceding loa) is not at all the terra nullius over which the Spanish Empire can claim dominion (Wynter, 1991, p. 252). This is crucial because it changes the purpose of the sacrifice, the meaning of the propter nos, and the meaning of what is human and what is not (considering the "nos" of the propter nos as "we, humans"). We need to bear in mind that not only does sor Juana refuse to present the world "discovered" by Columbus as a new world, but rather, as one already inhabited; she also states this assertion through the character of Columbus himself. It can be inferred that she is criticizing the bona fides of Columbus' mission, highlighting his is a desire to conquer a land, rather than merely to discover a new route. In sor Juana's loa, Columbus defeats both the ancient world represented by Hercules, and the ancient belief that the world ends at the Pillars of Hercules. Yet, is this the end of the loa? Certainly not.

There is a last move by sor Juana to criticize the conquest, creating the aforementioned analogy between the expedition and the Washing of the Feet. The analogy is introduced by a passage in which Estudiante 1 and Estudiante 2 are the protagonists. They ask the wise Estudiante 3 several times to explain the link between the 
history of Colón and the main argument of the auto that has the Eucharistic sacrament as its center:

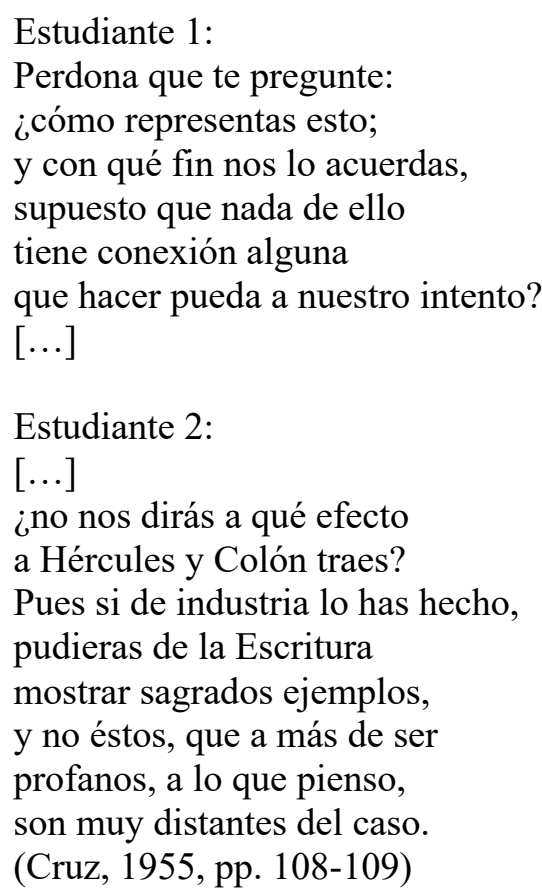

Now, after these questions, which center around the fact that Estudiante 3 is explaining a theological argument using two profane examples (Hercules and Columbus), instead of examples that come from the Scriptures, Estudiante 3 offers a complex reply that needs to be seen in the context of the loa to El Divino Narciso (analyzed above) if it is to make sense. The nexus between the conquest and the expedition by Columbus is represented by the Last Supper and the Eucharistic sacrament. As a short reminder, the characters in the loa to El Divino Narciso were caught in the moment to celebrate the rite of Teocualo - to eat God-and Religión convinced them that it was the same rite of the Eucharistic Sacrament. The sacrifice of God is then depicted by this moment of being eaten by His own believers. This is the ultimate sacrifice made, both by God in the Christian religion, and by America in the moment in which, once conquered, she is “eaten" by the Europeans. 
The link between the Eucaristic Sacrament and the mission of Columbus here is complex and hard to convey, For this reason, in the previous section I presented the loa to El Divino Narciso and here I present the loa to "San Hermenegildo", thus introducing the sacrifice of the Teocualo and the analogy with Christianity made by Religión before going into the analogy with the Sacrament in which, also in the Christian religion, God is transubstantiated into bread and wine. ${ }^{66}$ Indeed, without the foregoing, the answer that Estudiante 3 delivers would be particularly obscure:

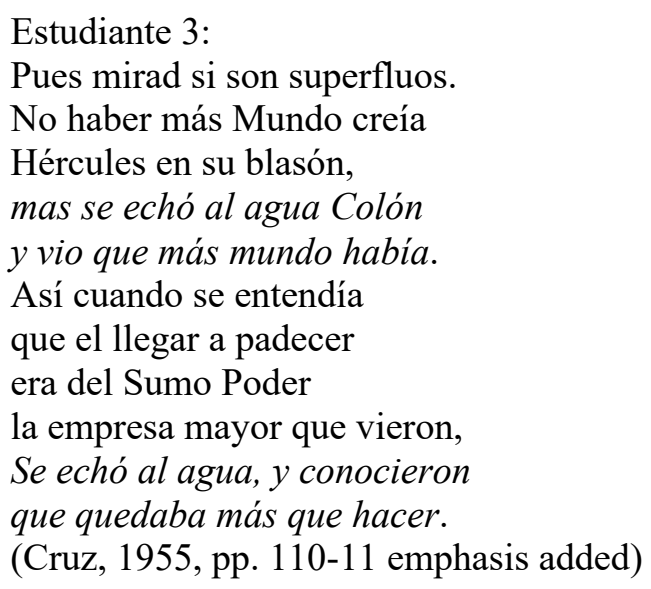

The above text expresses the answer in two parts. First, there is Columbus who se echó al agua [threw himself to the water] and who saw (care is required here, as sor Juana does not use the verb "to discover") that there was "more of the world". The nuance here is specifically not a "New World", but "more world"- a different world made of the same matter as the ancient one and not of some new, previously undiscovered matter. Second, the image of the Last Supper is introduced in these verses, and the Washing of the Feet that preludes the Eucharistic Sacrament in the Christian tradition. Sor Juana's text

${ }^{66}$ Generally, the two loas are presented in a different order: first the loa that introduces El mártir del Sacramento, San Hermenegildo; and then the loa that introduces El Divino Narciso. This is because it is the order that follows the logic of the events narrated: first the expedition of Columbus narrated in the loa of El mártir del Sacramento, San Hermenegildo; and then the conquest of Tenochtitlan/Mexico City narrated in the loa of El Divino Narciso. 
suggests that the twelve apostles knew that "quedaba más que hacer" (there was something more left to do). The "more" represented here is, in my opinion, what transforms the characters of América and Occidente from the previous loa to El Divino Narciso, into a sacrificed land, literally meaning America and the West. In this way, sor Juana is going from an allegorical view of the conquered land to a realistic interpretation of this land in which it appears as inhabited and not at all created only to be exploited by Europeans. According to sor Juana, Columbus embarks on an expedition toward an inhabited land that is thus in no way the terra nullius - the so-called uninhabitable torrid zone - described in scholastic tradition. Therefore, I argue that sor Juana distances herself from the classic interpretation of Columbus's expedition as an expedition that made a crucial contribution to humankind, since a vast geographical area was absorbed into the Christian world. Contrary to this one-sided narration, sor Juana does not erase the native inhabitants of America from the image of the "discovery". With her work, she undermines the idea that it was a "nobody's land", a terra nullius, and for this reason appropriable and conquerable.

This journey, from the conception of the New World as "new" and "undiscovered" to sor Juana's idea of the mission of Columbus as an expedition toward an unknown land that maintains a substantial continuity with the Old World, is crucial because it subverts the idea of the propter nos that guided the relationship between Europe and the Americas during the colonial era. Indeed, if a terra nullius is a land that Europeans can exploit because it was created in Europe's favor, then a land that already belongs to another population should not be sacrificed following the logic of a propter nos in which the preposition propter introduces only a final cause. Rather, the sacrifice has to be thought in accordance with the logic of a propter nos that introduces a causal close. This entails 
a change of emphasis in which America is sacrificed not for (propter) Europe, but because of (propter) Europe.

In this sense, I think that a new reading of the loas by sor Juana in light of Sylvia Wynter's (1995, p. 14) interpretation of the "Janus-faced" 1492 is essential. Such a reading changes the traditional perspective from which Europe looks at the New World and finds a third, alternative way to analyze and combine together the various elements that metaphorically constitute 1492. Among these elements, the idea of sacrifice according to Wynter (1995, p. 16) assimilates the human sacrifices that were part of the Aztec rites to maintain the "flow of life" with the sacrifice of Columbus which aimed to maintain the "flow of gold" (Wynter, 1995. p. 16). This assimilation casts a different and interesting light on the aspects of sacrifice (the human sacrifice, the Eucharistic Sacrament, the propter nos) that sor Juana also underlines as common to both the Christian and the Aztec world. In the reading of both loas, there is a sort of primordial attempt to go beyond the common interpretations of 1492-interpretations that are, in Wynter's (1995, p. 5) estimation, represented by dissidents and celebrants. Rather than a simple common trait between the two interpretations, sor Juana proposes a position in between, able to dismantle the Medieval vision of the world on the one hand, and to criticize the violence perpetrated by the conquerors on the other.

This reflection also entails what (or who) is considered human and the position such an idea of the human occupies in the history of the conquest. In criticizing the Medieval vision of the world, while simultaneously underlining that the land conquered by Columbus was inhabited by people who do not need to be converted since they already celebrate the "proper" Sacraments (as we read in the loa to El Divino Narciso), sor Juana is subverting the idea of humanism with the hegemonic human at its center, in favor of a 
humanism with the idea of the human on the horizon-as Wynter proposes in her conversation with Katherine McKittrick (McKittrick \& Wynter, 2015, pp. 23-24). Wynter categorically affirms:

And notice! One major implication here: humanness is no longer a noun. Being human is a praxis. $[\ldots][\mathrm{W}] \mathrm{e}$ have to replace the ends of the referent-we of liberal monohumanist Man2 with the ecumenically human ends of the referent-we in the horizon of humanity. (McKittrick \& Wynter, 2015, pp. 23-24)

Here Wynter underlines the importance of subtracting space to the idea of the hegemonic monohumanist Man2 and replacing it with a referent-we that finds its place in a plural horizon of humanity. Similarly, in sor Juana's texts, the pluralization of the idea of the conquered lands, specifically of Mexico, and the idea of a land that is not created for the benefit of Europe, undermine the belief that the conquest occupied a no one's land, positing the accent on that "no one" and transforming it from the annihilation of preHispanic humanness into part of the praxis of being human.

It is interesting to notice that sor Juana is able to perceive the problematic of the sacrifice and the sacrificed land precisely because she is criolla, and therefore she does not belong to those who fully classify as human (the Christian Europeans), nor to those who suffered the violence of the conquest (the indigenous populations). It is this position "in between" that allows her to think in terms of propter nos, problematizing the "nos" and questioning for whom the land was created. This passage is fundamental to better understand what it means to live "in between", and how sor Juana represents the moments of the conquest and the mission of Columbus. It becomes clear that for sor Juana, it is "easier" to approach the mission of Columbus starting from an intricate theological 
argument. This is relevant because it shows that she did not perceive the mission of Columbus as independent from a divine project, while at the same time, the project that sor Juana presents diverges from the common idea that America was created and sacrificed propter nos homines as a terra nullius.

\section{Sor Juana: Curdling in Between}

Thus question guiding this chapter has been to interrogate the possibility of including sor Juana's corpus into a specific literary canon. In order to answer this question, in the preceding sections, mainly through the analysis of the two loas (the loa that precedes $E l$ Divino Narciso and the loa that precedes El Mártir del Sacramento), I highlighted three aspects that characterize sor Juana's approach to colonization: the relationship between Europe and America; the conquest of Mexico; and the mission of Columbus in 1492. This path through sor Juana's compositions dedicated to America showed how sor Juana's corpus resists being categorized, and should instead be placed in the impossible space of in-betweenness, both as a criollo and in view of her unplaceable discourse on America and Europe. In this section, I return to the question of her position in the literary canon from a different perspective, considering the concepts of genre and canon as acts of colonization.

The "in-betweenness" that sor Juana claims in the works I examined, opens up the possibility to let the text speak without confining it, without superimposing structures on the text, without translating it, and without the necessity to enter into a relationship with dominant thought. In this sense, the question of whether it is possible to place sor Juana's work into a literary canon, is transformed into a different question: "What do we miss in sor Juana's corpus if we attempt to confine her work to a specific canon?" The answer to 
this question brings us back to that space of in-betweenness that constitutes the impossible space from which sor Juana speaks. For this reason, I dedicate this section to a close examination of this in-betweenness in which sor Juana declares herself to be- the lack of any concrete status, condition, or group — connecting this with the idea of curdling, as borrowed from Lugones, and with the idea of nepantla.

As we saw in the preceding sections, sor Juana lives exactly "between" the era of the conquest and the era of an independent Mexico, embodying, at the end of seventeenth century, an early patriotic feeling juxtaposed with a general sense of belonging to a Spanish Empire that actively tried to fragment Mexican society-a process of fragmentation that occurred not only in the colonies, but also in Europe. We saw how sor Juana's reading of Mexican society, of the conquest, and of the mission of Columbus are, as always, original, even if particularly convoluted. By encompassing all the different facets of Mexico - the yet-to-exist independent country; the role of América and that of Occidente in the loa that precedes El Divino Narciso; the emphasis on the fact that America is a land inhabited by autochthone ancient traditions in the loa that precedes $E l$ Mártir del Sacramento; the land in which different languages are spoken (Spanish, Basque, Nahuatl, the manner of speaking of the Afro-Mexican population) in the quoted poems and villancicos—-sor Juana enhances Mexican differences in an act of "curdling" rather than "fragmenting” (Lugones, 1994, p. 460).

This difference, between curdling and fragmentation proposed by Lugones, is crucial if we are to understand precisely why sor Juana is not locatable within any canon. The terminology of curdling I have borrowed from an essay by María Lugones entitled "Purity, Impurity, and Separation". Through the metaphor of the "separation" of the ingredients of mayonnaise, Lugones (1994) is able to explain something crucial about our 
path toward the disaggregation of the idea of genre in sor Juana's texts and the unplaceability qua canon that this entails. In Lugones' words, the difference between curdling and fragmentation is the following:

My aim is to distinguish between multiplicity (mestizaje) and fragmentation and to explain connections that I see between the terms of this distinction and the logics of curdling (impurity) and of splitting (purity). Fragmentation follows the logic of purity. Multiplicity follows the logic of curdling. The distinction between fragmentation and multiplicity is central to this essay. I will exhibit it within individuals and within the social world. According to the logic of curdling, the social world is complex and heterogeneous and each person is multiple, nonfragmented, embodied. [...] According to the logic of purity, the social world is both unified and fragmented, homogeneous, hierarchically ordered. [...] Fragmentation is another guise of unity, both in the collectivity and the individual. (Lugones, 1994, p. 463)

The logic of purity, according to Lugones, is one that establishes a hierarchical orderone that maintains the social world under a enforced cohesive power that recognizes its fragments as part of a homogeneous collective. Conversely, the logic of curdling recognizes the heterogeneity and complexity of each person. This recognition of multiplicity (impurity, mestizaje) opens up the possibility of distinguishing between curdling as an act of differentiating the different parts of a non-fragmented element and splitting as an act of differentiating the different parts of a fragmented element. In this sense, difference is a condition in which each curdled part cannot be isolated from the others, while, if considered from the logic of purity, the "same difference" becomes the mark of an impurity that can be fragmented, separated, and isolated at any moment. 
Imaging sor Juana's corpus as a curdled and non-fragmented element allows us to recognize its multiplicity precisely without the intention of establishing a hierarchy between the works that constitute the corpus itself.

The above-cited quotation also introduces the core questions of this section: How best to approach sor Juana Inés de la Cruz's corpus, especially the lyric poems, and why her work is placed into so many different canons (for example, the canons of Mexican literature, Hispano American literature, Baroque literature, colonial literature, Spanish literature, and women's literature)? Each canonical entry, in effect, forces sor Juana's work to undergo another process of assimilation that provokes an erasure and a consequent loss of specificity. For example, by entering the canon of Baroque literature, its American specificity is put at risk, while when she is considered to be a colonial author, any attempt to criticize the colonial situation is inevitably compromised. Each act of erasure amounts to the separation of an element - a fragmentation of sor Juana's subjectivity that, upon each act of separation, renounces a certain aspect of her corpus. As with the term Geschlecht, if only one aspect is considered central, other aspects are lost. Renouncing all else to a single aspect of her literary production represents not only a loss, but also an act of forced assimilation. As it happens with the blows that mark the division of the unitary meaning of Geschlecht (Derrida, 2008, p. 51), an imaginary axe falls over sor Juana's corpus, cutting out entire works that are considered superfluous or incompatible with the primary theme of the canon. This phenomenon is compounded by the fact that sor Juana can also be considered a woman, a criolla, a Mexican, an American, or a feminist (each the identification for a specific canon). Every time the imaginary axe falls, it severs a piece of the singularity of sor Juana herself. At the same time, each fall of the axe reveals how the concept of "the canon" is fundamentally exclusive-for its 
own constitutive nature, it is an exclusionary space based on a strict hierarchy that regulates which texts are admitted and which are not.

As I already mentioned above, even if the structure of sor Juana's texts is very respectful of the norm, often the topic (the heart of the composition) or how that topic is presented (considering the rhetorical strategies, or the figures of speech used) infringes upon expectations, thus troubling the placement of the text into a definitive canon. Rather than being only a woman, only a criolla, and only a writer during the colonial era, she embodies all of these features, albeit often in opposition.

The multiplicity present in sor Juana's corpus is self-evident and unavoidable. It became evident in the very first work analyzed in this dissertation, El Neptuno Alegórico, up to and including the choral confrontation between the characters of the loas analyzed here. This multiplicity also crosses the space of what is untranslatable, not only because sor Juana does not translate any of the languages she uses into Spanish (except for Latin), but also because her multiple, valuable, and varied style, as well as the use of different sources, references, and topics, make it impossible to approach and welcome her corpus into any singular canon.

To explain what happens when the imaginary axe falls over the corpus, enhancing and underlining only some aspects of sor Juana's corpus, I would like to refer again to the essay of María Lugones (1994, p. 470), who explains the relationship between the terms "Mexican" and "American" in the binomial "mexican/american" perfectly: "The mexican/american can assimilate because the mexican in mexican/american is understood to be a member of a superfluous culture, the culture an ornament rather than shaping or affecting American reality." This quote demonstrates how there is always a risk in assimilating two or more elements since, in order to make assimilation possible, one 
element has to be predominant, the other elements being the "ornament" rather than being actively involved in the pairing. In a certain way, it is possible to affirm that each multiple aspect of sor Juana, according to the logic of the canon, to the logic of the nation or, in Lugones' terms, according to the logic of fragmentation, is assimilated for being superfluous and not for its ability to affect the corpus itself. For example, the multiple voices of Mexico can represent just another Baroque feature of assembling several elements into a single space, but it can also be considered as a revindication of a plurality that describes a reality very different from the criollo tendency to group together all the non-Spanish components of the Mexican society under the Aztec group, as if it were the only group worthy of attention.

How best to resist this tendency to erase singular and individual traits? There are two main types of resistance that sor Juana puts into action in her writings. First, she avoids generalizing or comparing the pre-Hispanic past to some singular culture that combines indigenous and criollo influences. Second, she always positions herself outside of any group, yet always with the ability to enter that space. In other words, she occupies a space "in between" that I would like to translate using the Nahuatl term "nepantla"-a term that, as we will read in the next paragraph, also appears in the famous essay Borderlands/La Frontera by Gloria Anzaldúa (1987, p. 100).

The first form of resistance is important because, in the narration of America and Mexico proposed by sor Juana, there is no assimilation of cultures. For example, the realities that live outside "México" (a geographical space translatable as Mexico City rather than Mexico, since today the space of the Republic covers part of the ancient space identified with "New Spain"), or other pre-Hispanic populations (among others the Mixe, Maya, Zapoteca, Mixteca, and Mazateca cultures and languages) are left "outside" to the 
benefit of the stronger and powerful Nahuatl culture. Nonetheless, it is remarkable that sor Juana in the loa to El Divino Narciso distinguishes America from the West into two distinctly different characters. Moreover, in creating a comparison between classical ancient Latin and Greek cultures, the Nahuatl culture enhances its subjectivity, becoming a "noteworthy" culture with a "noteworthy past". Simultaneously, the criollo grouprepresented by those passages in which sor Juana is "curdling" society, admitting those who can affirm "my homeland" (mi patria) in reference to Mexico, but who are not indios - does not acquire a subjective, strong position, but rather remains suspended between the attempt to defend the Aztec Empire, and the Spanish group of peninsulares in possession of political, spiritual, and economical power. It is interesting that sor Juana describes her own writings as "contaminated" in a positive way by the potion made by "los indios herbolarios de mi patria" (Cruz, 2018, p. 158; which in English could be translated as "the Indian herbalists of my fatherland"), making "thick" (Lugones, 1994, p. 474) not only the existence of the powerful Aztec heroes, but also the hidden, vulnerable presence of Indian herbalists. I need to specify here that the meaning of patria used by sor Juana differs from the current meaning of the word because, as Antonio Rubial García (2005, p. 348) explains, the term patria indicates the space where someone is born. Also, the term nación [nation] had a different meaning in the seventeenth century, since it does not indicate the geographical space delimitated by political borders, but rather is the space (not necessarily geographically contiguous) in which a community shares traditions, religion, and language. ${ }^{67}$

\footnotetext{
${ }^{67}$ In the same essay "La patria criolla de sor Juana y sus contemporáneos", Antonio Rubial García (2005, p. 348) specifies that the terms "nación" [nation] and "patria" [homeland] are more frequent than the term "país" [country] and "colonia" [colony].
} 
Undoubtedly, the criollo presence is made "thick", however, this does not mean that it is a presence that acquires increasing "substance". In fact, quite the contrary is true. Following Lugones's (1994) argument regarding the use of the term "thick":

Individuals are thick if they are aware of their otherness in the group, of their needs, interests, ways, being relegated to the margins in the politics of intragroup contestation. So, as transparent, one becomes unaware of one's own difference from other members of the group. (Lugones, 1994, p. 474)

This difference between thickness and transparency is crucial to understanding the second form of resistance - that concerning the Nahuatl term nepantla. In this regard, it is noteworthy that sor Juana's writing, seen as the space in between European soil and American traditions, is "invaded" by the magic of the Indian herbalists and thanks to this "perfusion" is made worthy of the attention of European readers.

The English translation of the Nahuatl word nepantla is "in between"-a space that does not belong to any definite side. Starting from the first link that appears between sor Juana and the word nepantla, as the first biographer of sor Juana, her friend Padre Diego Calleja reminds us, she was born in a village called San Miguel Nepantla-that is to say, San Miguel "in between", because the village is situated between the two main volcanoes of the Valley of Mexico: Popocatepetl (the smoking mountain) and Iztaccihuatl (the white woman). ${ }^{68}$ According to Padre Calleja, sor Juana's nature was forged between these two natures: the active, dangerous, and fiery temperament of Popocatepetl; and the

\footnotetext{
${ }^{68}$ As a reference in this dissertation, I used a modern transcript of the Aprobación del Reverendísimo Padre Diego Calleja, de la Compañía de Jesús by Giuseppe Bellini in his Sor Juana e i suoi misteri. Studio e testi (Bellini, 1987, pp. 53-64).
} 
docile, mild, and passive nature of the Iztaccihuatl. Going beyond this initial meaning of living "in between", sor Juana represents the embodiment of several other "in between" "spaces". For example, the resistance to genre that I termed "sexistance"-present also when it comes to allowing her corpus to enter into a singular canon-can be approached from different perspectives.

The central tenet of these perspectives will help us to define the very word "position" and is grounded in the considerations that Gilles Deleuze (1990) proposed in a conversation with Robert Maggiori about Leibniz. This conversation was first published in Libération, subsequently collected in Pourparler (Deleuze, 1990), and translated into English as Negotiations (Deleuze, 1995). I would like to start from the definition of "point" that provides this conversation's central theme, not least because it will be useful to introduce the space of nepantla as a non-space-a space that is impossible to assimilate and that, for this reason, makes it impossible for sor Juana to belong to any singular group. Deleuze states:

I don't like points; I think it's stupid summing things up. Lines aren't things running between two points; points are where several lines intersect. Lines never run uniformly, and points are nothing but inflections of lines. More generally, it's not beginnings and ends that count, but middles. (Deleuze, 1995, p. 161)

This first consideration links the ideas of singularity and sexistance, examined in the central portion of this dissertation, with the problematic issue of structurally approaching the work of an author who unceasingly affirms not to belong to any homogeneous group. Similarly, the points and lines in Deleuze's quote do not belong to a delimited space, nor are they the result of an additive function. Here, lines are the result of numerous 
intersections rather than something "running between two points", and points are moments of inflection and folding. However, the most important part of the quote is the final line in which Deleuze affirms (1995, p. 161): “More generally, it's not beginnings and ends that count, but middles" (emphasis added). Thus, I can safely shift to what matters: nepantla - the middle. Yet to fully approach the concept of "the middle" in sor Juana's literary production, I need to introduce the term from two different perspectives. The first is the middle (nepantla) as presented by Gloria Anzaldúa (1987, p. 100) in Borderlands/La Frontera. The second angle is the impossibility of translating the term according once more to what Emily Apter (2013) argues in her essay on untranslatability.

Importantly, here I understand and use the term "translation" in the context of its Latin root "transferre", which conveys the idea of transposition and movement from one place to another. In this passage of ideas from one place (or one idiom) to another place (or idiom), many aporias occur. First, the passage marks a "checkpoint" (Apter, 2013, p. 99) in which the correspondence between the two places intersects the conceptual space inhabited by the question that asks what the ethical purpose is of translating and moving ideas toward a second space, which so often performs the role of the adjective American in the pair mexican/american as explained by Lugones. In other words, the language, metaphors, indeed the very word "nepantla" that characterizes sor Juana's work, represent terms that cannot easily be translated, since they deny a place of origin and do not recognize a monolithic point of arrival. This latter idea is visible in sor Juana's work, especially when she talks about America, because here there is an explicit reference to differences and multiple voices erased by the conquest through its act of fragmentation. What sor Juana does in her writings, is an act of re-composition and curdling of the idea of a society governed by the criollo people and inspired only by the magnificence of the 
memory of Aztec culture, in an operation of cultural appropriation. The pivotal meaning of the connection between translation, nepantla, and sor Juana's work, is precisely this refusal to belong to either communities: the criollo group, and the Spanish elite. This refusal, although more clearly stated, is no different from the refusal that sor Juana enacts when she denies belonging to a sex or a genre. Of course, it is impossible to express this particular "position" because it involves precisely a refusal to indicate belonging and origin. Even when she does affirm "mi patria" (my homeland), she underlines an existing cohabitation with different cultural elements that merge in her poetry.

The contemporary idea of translation, absent in sor Juana, is then an obstacle rather than a bridge. Each time sor Juana's corpus is absorbed into a canon, it counts not as a middle, as Deleuze claims, but rather as an origin. Instead, I emphasize the "middle position" in which we can find sor Juana's corpus. In the same way, it is possible to find the description of a dematerialized subject caught in the folding moment of being both alive and dead simultaneously (the Phoenix), and to place sor Juana's corpus both outside and inside several canons. Not recognizing this perpetual border-crossing of canons means not recognizing the plural dimension of her texts. Sor Juana is mestiza, not in the common sense of the term as an actual daughter of an indigenous and a Spanish person, but because it is possible to find in her a state of "psychic restlessness" (Anzaldúa, 1987, p. 78). As Gloria Anzaldúa remarks in her famous essay Borderlands/La Frontera. The New Mestiza, it is possible to affirm that also sor Juana's production is in a perpetual state of nepantilism:

In a constant state of mental nepantilism, an Aztec word meaning torn between ways, la mestiza is a product of the transfer of the cultural and spiritual values of one group to another. Being tricultural, monolingual, bilingual, or multilingual, speaking a 
patois, and in a state of perpetual transition, the mestiza faces the dilemma of the mixed breed: which collectivity does the daughter of a darkskinned mother listen to? (Anzaldúa, 1987, p. 78)

This state of nepantilism is where we can find sor Juana's corpus. This state is a result of the "colonial condition" and the colonial rewriting of Mexican history against which sor Juana pits her critique. The presence of the Nahuatl language; other languages representing the composite Mexican society; the difference established between "America" and "the West"; the use of Nahuatl words in a Spanish context; the underlining of the abundance of goods produced on American soil; and acknowledging the economic and social exploitation of American lands - these are all narrative strategies adopted to place the "nation" that the criollo group is building in a state of crisis. This state of crisis extends to the overrepresentation of an idea of mestizaje that is nothing less than blatant cultural appropriation. In the passages of the loa in which sor Juana "curdles" the history of America, and in the passages in which Mexican society is described apart from its continuity with the Aztec empire (which so often characterizes official narration of Mexican history today), we find a silent yet powerful critique of the very roots of the current Mexican nation. This narration is described by Octavio Paz (1988) in Sor Juana as follows:

Mexico was born with the Aztec state, or even earlier; it lost its independence in the sixteenth century and recovered it in 1821. According to this idea, between Aztec and modern Mexico there is not only continuity but identity; both are the same nation, which is why we say that Mexico recovered her independence in 1821. New Spain was an interregnum. (Paz, 1988, p. 11) 
This narrative of Mexico — one of "continuity" and "identity" between the Aztec and the post-colonial situation — fails, not only because it is evidently "colored by myth" (Paz, 1988, p. 11), but also because of issues related to the aporias of translation expressed by Lugones. Indeed, the recovery of independence is linguistically subjugated to the Spanish language. As Lugones (2007, p. 191) remarks in "Heterosexualism and the Colonial/ Modern Gender System”, analyzing Quijano's model of “global, Eurocentered, capitalist power", the hegemony of the Spanish language that sor Juana undermines is equal to undermining a Eurocentrism that, following Quijano, Lugones declares as "not of Europeans only, but of the Eurocentered world, of those educated under the hegemony of world capitalism" (Lugones, 2007, p. 191).

Another important feature of sor Juana's "curdling" of society is her refusal to become part of a homogeneous group, instead depicting a heterogeneous and choral society. This operation connects with the idea of a mestizo in which different elements concur to create a non-homogeneous texture-embodying a textual politics from which emerges multiplicity and a claim against "social homogeneity" (Lugones, 1994, p. 475). This is an important point because, as Lugones argues, behind the idea of "social homogeneity" there is a complex structure of domination: "Social homogeneity, domination through unification, and hierarchical ordering of split social groups are connected tightly to fragmentation in the person. If the person is fragmented, it is because the society is itself fragmented into groups that are pure, homogeneous" (Lugones, 1994, p. 475). This passage by Lugones highlights precisely the contradictions and difficulties that sor Juana denounces in using her writing as a material instrument of speaking out against homogeneity. Always keeping in mind the difference between the act of 
separation and the act of fragmentation described by Lugones (1994), it is impressive how sor Juana is able to conceal such a profound critique of the colonial system beneath various small details. First, in the loa to the Divino Narciso, sor Juana presents the idea of America as heterogeneous with regard to the West. Second, in the villancicos, she employs different languages spoken in New Spain. Third, she does not translate the tocotines written in Nahuatl. Finally, and most significantly, she recognizes the exploitation of America by the Europeans. This latter point is inseparable from those that precede it, because it demonstrates the existence of a Eurocentric perspective on society that is fragmented in order to establish a distance between "pure" and "impure" Europeans, but also a Eurocentric affluence that does not respect the place of extraction of the goods it consumes.

According to Luis Leal (1993), the variety of elements that coincide to form the villancicos, the loas, and the other poems and texts in which the indigenous element appears (either in the form of a language, or as a character) allows sor Juana to establish a dialogue with the marginalized classes, instead of attempting to reclaim a specific criollo identity that uses (or abuses) the concept of mestizaje only to legitimize its dominance over the indigenous people (Leal, 1993, pp. 199-200).

The resistance exercised by sor Juana against the act of belonging and against the principle of non-contradiction is made more interesting because of the colonial system. Indeed, when sor Juana declares as hers a homeland that in fact does not exist independently from the Spanish Empire, she is declaring a sort of "fake" belonging, demonstrating that, on the one hand, it is possible to perceive her as not Spanish, but on the other hand, she is not "Mexican" either. She is "criolla": a particular kind of mestizaje who does not only belong to the novohispano society, but also to other colonies. When 
sor Juana claims this impossible belonging, she is using the same mechanism that allowed her to be simultaneously alive and dead, or to affirm that she is not a woman without explicitly stating what she is: She suspends the ideas of origin and position, enhancing and highlighting the contradictions of the colonial genre system, a system that is only able to think in terms of presence and essence, and that automatically excludes what lives on the edge, what is in the middle-what is nepantla. The loas and the poems analyzed and quoted in this chapter demonstrate once more that the process of colonization reinforced the idea that it was "necessary" to categorize literary production into canons, instead of recognizing the process of curdling, erasing all literary works that, rather than collocating themselves within a particular, defined genre, exist "in between" (nepantla).

\section{Conclusion: Sor Juana Today}

Throughout this dissertation, I have endeavored to reveal how sor Juana, through her extensive oeuvre, represents the upheaval of a singularity that resists and refuses categorization and definition. Subjectivity in sor Juana is posited always outside of any paradigm that might force the subject to occupy a position within pre-defined possibilities - between absence or presence, between female or male, between life or death, between being Mexican or not. My focus has been primarily on the individuation of an alternative narration of sor Juana's literary corpus, to enhance those traits that create a direct clash with hegemonic Cartesian philosophy based on the supremacy of a subject that constitutes reality only by thinking in the first person ("I"). By highlighting important 
traits of sor Juana's corpus - the fluidity of the subject, the impossibility of a definitive sexual categorization of the subject (distinct from a mere sexual neutrality), the deconstruction of the "life / death" binary, and a profound resistance to being easily named or defined - I have offered a different perspective on sor Juana's works. Such a perspective is helpful to make a detailed analysis of her words in order that these words might reveal more clearly the complex and fascinating universe that her work, and indeed sor Juana herself, represents.

With this journey into sor Juana's work and in particular her style of writing, I have aimed to demonstrate that in sor Juana's writings there remain many undiscovered nuances and unexplored paths. The primary focus of my research was the analysis of those works in which sor Juana deconstructs the hegemonic conception of a stable subject when considered as something that is always sexed, present, placeable, and reproducible. By focusing on the intricate Baroque style of the texts themselves, in each chapter of this thesis I have established which contribution sor Juana can make to contemporary debates on sex, subject theory, and positionality. In doing so, I have revealed an exciting nexus between her texts and the processes of deconstruction of the metaphysical subject that continue to this day-most notably with Derridean deconstruction and the topic of sexedness, and with the critique of the colonial over-representation of the subject performed by Sylvia Wynter regarding the coloniality of Being. This nexus, between sor Juana's corpus and poststructuralist theory, is revealed by the fact that in sor Juana's work the subject always remains fluid, for example as seen in the analysis of sor Juana's $E l$ Neptuno Alegórico (Cruz, 1957, pp. 355-410) and Primero Sueño (Cruz, 2018, pp. 257299) conducted in the first chapter. 
At all times I tried to respect the complexities and ambiguities of the texts analyzed. I achieved this by asking the reader to take time and effort to comprehend each text, with the purpose of demonstrating not only their untranslatability but also the extraordinarily interesting and fascinating universe that sor Juana reveals to us by using writing to express her corporeality. In addition, the thesis has pursued a specific theoretical trajectory, drawing the reader into the irreproducibility of sor Juana's words with the intention to show that singularity and polysemy can occupy the same poetic space.

And yet, this space remains unplaceable and difficult, indeed sometimes impossible, to restrict to a specific genre. This unplaceability became especially clear in the fourth chapter, where I approached the question of writing from an "in between"/nepantla position. Thus, as this dissertation shows, not only is sor Juana's subject difficult to trace, but the space of this subject is also marked by a profound indefinability. This unplaceability also emerges from the specific condition of sor Juana as criolla, being neither Spanish nor indigenous, instead living "in between". Yet throughout this dissertation, I have never perceived these difficulties in a negative sense. Rather, following the example of sor Juana, who considers the inaccessibility of the cloister as an opportunity to exercise her freedom, I have embraced these difficulties as an enriching challenge. Always conscious of remaining open to her work, I tried to focus on the multiplicity of its myriad possible interpretations - to the meaning of a body of work and of an author who specifically does not want to be defined or captured in some ultimate explanation. I interpreted both the amphiboly and the complexity of the passages that sor Juana offers in her poetry as part of her attempt to escape hegemonic normsunderstood as a process that pretends to be natural and fully comprehensible. In difference 
to normativity, her work demonstrates a profound desire always to head in the opposite direction and, to this end, it can often be considered as "unnatural" and "convoluted". I have preferred not to stress this aspect of sor Juana's texts, instead allowing this quality to emerge, making space for the plurality of the meaning that the lines and verses can have, rather than simply "explaining" them. Throughout this thesis, I also had occasion to lose myself in the labyrinthine texts, often without a clearly defined exit.

Sor Juana's contribution to the debate about subject and sexedness is realized also by the invitation that sor Juana makes throughout her works never to fall into the trap of identity. Indeed, sor Juana never identifies herself with steady forms of identity, in this way denying power to processes of identification, preferring instead to be associated with dynamic realities, such as the idea of the subject that she proposes in her writing.

To evidence the dynamism of this subject, I insisted in the first chapter on the fluidity of the subject, analyzing two texts: El Neptuno Alegórico and Primero Sueño. These two texts show the complexity of sor Juana's discourse about the subject, and the merit of adopting a poststructuralist perspective that underlines the central tenet of both texts: The subject is not a strong and steady reality, but a semiotic and fluid concept that escapes definition. To better understand this complex process of fluidification of the subject and the reference to the labyrinth, it is crucial always to think in the main figuration of the Baroque: the fold. Reading sor Juana's texts through the concept of the Baroque subject derived from The Fold by Gilles Deleuze (1993), which emphasizes the role of the fold in Baroque philosophy, an idea of subject was revealed that is often concealed by images or rhetorical processes in sor Juana's corpus. For example, when, at the end of Primero Sueño, sor Juana writes the famous "yo despierta" (Cruz, 2018, p. 299), the feminine adjective "despierta" may refer to a "yo" ("I") that is polysemic and that can be taken as 
the "I" of the soul (a noun that agrees in feminine in Spanish), or to the "I" of the author, if we agree that is a female author who writes. Here, the subject of the poem reaches the peak of its immateriality and becomes a specter as presented by Jacques Derrida in Specters of Marx (1994) — that is to say, as something that, like the soul in the poem by sor Juana, puts time out of joint. This specific formation of the subject, which culminates in the moment it achieves female corporeality in Primero Sueño, allows me to question the sex of this subjectivity.

In Respondiendo a un caballero del Perú, que le envió unos barros diciendola que se volviese hombre (Cruz, 2018, pp. 117-123), analyzed in the second chapter, we find the answer to this question. This answer, which presents the focus of the second chapter, is condensed into the line that begins with the strong assertion "pues no soy mujer" (therefore, I am not a woman). Sor Juana here affirms that in order to be considered a woman, she should act like one. Being a nun and living in a cloister, she affirms that she cannot be considered a woman, and for this reason, she cannot change her sex, as the gentleman from Peru suggests. After the detailed close reading of the poem, it is clear that sor Juana considers sex as a doing, rather than a status. Following this consideration, in the second chapter I have introduced to the theoretical framework a text by Jean-Luc Nancy (2017). In Sexistence, Nancy claims that we do not only exist outside the sphere of the Being, but that we also s'exist in a sexed existence in which, as sor Juana claims in her poem, sex is an act. Nonetheless, in articulating her response to the gentleman from Peru without accepting to be classified as either a man or a woman, sor Juana also demonstrates an act of resistance. This specific act of resistance, which I called sexistance, adds to the previous configuration of the subject analyzed in the first chapter a more active characteristic. Indeed, this subject placed itself, not only outside sexual 
binarism (being either male or female), but also beyond the principle of non-contradiction that forces any entity to be either this or that.

Sor Juana's categorical refusal to assume a steady identity is crucial if we are to understand that sor Juana's configuration of the subject also refuses the idea of a norm. norm understood as a pre-established condition that a subject has to respect. This refusal, traceable in the third chapter of this thesis, connects the impossibility of grasping the ultimate meaning of reality, with the impossibility of belonging to a specific category. By analyzing the poem, the original epigraph of which is Romance que respondio nuestra poetisa (Cruz, 2018, pp. 130-138), in which sor Juana replies to an anonymous poet recently arrived in New Spain from Europe, I have tried to emphasize the role played by the Phoenix and the peculiar interpretation of this creature that sor Juana offers in her poem. Here, I discerned four themes: the singularity of the Phoenix; the Phoenix as a creature that is both alive and dead in the same moment and in the same space; the obstacles that sor Juana needs to overcome in order to be compared to the Phoenix; and the impossibility for the Phoenix to have a genealogy. I do not consider these themes as mere characteristics of the Phoenix, or strategies to justify the comparison between sor Juana and the Phoenix proposed by the anonymous poet. Rather, in my reading of Romance que respondió nuestra poetisa, I perceive them as actual philosophical questions that undermine the relationship with the norm. Indeed, specifically in relation to the second and third themes, I highlighted two interesting points via Derrida's work, and in particular via his seminars collected in Life Death (Derrida, 2019). The first point is the lack of distance between life death, summarized by Derrida as the lack of the "and" and of the "is" (in French et and est) between the concept of life and the concept of death. The second point is individuated by the fact that the Phoenix is a male noun in Spanish 
and sor Juana needs to justify how a male noun can address her, a person considered as female. The infringement of the grammatical norm by transforming the male noun into a female noun is not supported by sor Juana, but rather, she deprives the noun of the possibility to address only what is classified as male. This simple move opens to the upheaval of the singularity against the norm, and against the "program of the and and of the $i s "$ as described by Derrida (2019, p. 4).

Moving to the fourth chapter, a last question remains unsolved: Where is this subject situated? Again, the answer provided by sor Juana is marked by an extreme ambiguity, calling into question not only the possibility to situate the subject spatially, but also temporally. As a consequence, it is impossible to place her work into a singular canon. In the fourth chapter, I have attempted to answer this complicated question by focusing on the problematic colonial context of sor Juana's life. First, I have analyzed the amphiboly of the year 1492 in order to look at this crucial moment in the early modern era from a perspective that emphasizes the multiple meanings that the year of the conquest of the Americas had for sor Juana — a year that does not only represent the "discovery" of a "new" continent, but also other events that occurred in Europe (for example the death of Lorenzo De' Medici) and marked indelibly the history of humanism. Guided by the understanding of amphiboly presented by Emily Apter (2013) in Against World Literature, and by the essays about 1492 written by Sylvia Wynter (1991, 1995, 2003, 2015), I have unpacked the meaning of 1492, proposing a reading of this event that is compatible with both sor Juana's view and a contemporary one. Second, the concept of America also changed through time and today cannot be translated into the same signifier. From the analysis of sor Juana's poems and villancicos dedicated or crossed by the topic of America, it results that sor Juana's idea of Mexico is particularly multi-faceted, 
comprising myriad co-existing languages and cultures. It was important to underline this aspect in order to understand that, when sor Juana wrote the two loas analyzed in this chapter, she clearly did not perceive herself as Mexican (considering Mexico as the area of the Valley of Mexico, inhabited mostly by Nahuatl/Aztec populations), nor as Spanish, since she was born on Mexican soil.

The two loas analyzed in this chapter are, first, the loa that precedes the auto titled El Divino Narciso; and second, the loa that precedes the auto El Mártir del Sacramento, San Hermenegildo. What results from this analysis is that sor Juana dedicates the loas to two specific aspects of the conquest: The first loa is dedicated to the conquest of the Mexican Aztec empire, and the second loa is a complex presentation of the expedition of Columbus. The close readings revealed how sor Juana's style of writing and of approaching the question of the conquest cannot be easily categorized, since she "curdles in between". Following María Lugones (1994, p. 463), curdling here refers to the way in which sor Juana highlights the multiplicity of the Americas, living "between" the condition of not being indigenous, nor Spanish. She occupies with her corpus a space "between" dualisms and dichotomic realities without belonging to any of these. The importance given to the idea of "betweenness" is also condensed into the Nahuatl word nepantla, meaning "in between", which is doubly connected with sor Juana. On the one hand, biographically, sor Juana was born in a village called San Miguel Nepantla, built between the two volcanos of the Valley of Mexico. On the other hand, nepantilism (Anzaldúa, 1987, p. 100) is a neologism that indicates the state of restlessness of the mestiza. This restlessness also characterizes sor Juana's works, particularly when it comes to the act of situating her corpus into a canon. Considered as the ultimate act of colonialism, from this perspective the canon represents a space in which an author can 
enter only if they possess the required characteristics-a requirement that sor Juana rejects each time she encounters the opportunity to be classified.

Concluding, this last move in this dissertation is the attempt to transform the mechanisms used to criticize the traditional idea of the subject into a method to deconstruct the ideas of nation and of the literary canon, both exemplifying acts of fragmentation (Lugones, 1994, p. 463) and colonization. My aim in this dissertation was to enhance and underline the upheaval expressed in those verses and passages in which sor Juana denies being part of a genre, or actively undermines a commonly held belief by adopting a double strategy: She leaves the question unsolved, as she does in the case of her sex; or she subverts the narrative, as she does in the loa to El Divino Narciso, where she entrusts the role of the more rational and intelligent character to an indigenous woman called América.

Together, all of these elements which the chapters in this dissertation bring to the fore create a composite picture in which the main theme is that to adhere to a fixed and predetermined category means to be conquered — absorbed by a process of assimilation in which a stronger and more powerful idea obscures the singularity, understood as that which is not replaceable nor translatable, considering it weaker. In her work, sor Juana demonstrates precisely a refusal — a singularity that refuses to be conquered, showing itself to be powerful and able to overcome any dichotomy, including that of life/death. For this reason, the allegory of the Phoenix was pivotal in my dissertation. The Phoenix knows no distance between life and death. It is unique and, consequently, refuses to be assimilated into any stable category or genre. The Phoenix was crucial, opening my investigation into the impossibility of placing sor Juana's corpus into any rigid, defined canon. The image of this creature, impossible to capture, helped me to question how she 
defines the place in which she lives, taking into consideration the profound colonial influence at that time.

In concluding, I would like to once more return to where this project began. At the very outset, I asked myself: Why sor Juana? Why today? Why does her corpus require another reading from a poststructuralist perspective? The answer I formulated in this thesis expresses the need to incorporate in the practice of research not only certainties and results, but also restlessness, a feeling of uneasiness, so perfectly represented in the works of sor Juana. The affirmation that emerges from the voice of sor Juana is not to be scared by what is amphibole or what is undefinable - for example, when, in the space of a single line, she denies that she is a woman (as we saw in the second chapter), or when she affirms that a Phoenix without beard can exist (as we saw in the third chapter). In my research, via the lens provided by my method, which is strongly influenced by the four essays by Derrida dedicated to Geschlecht, I enhanced the use of polysemy as a methodological praise of undecidability.

In many regards, sor Juana remains an enigma to this day. In my research, I have promoted new lines of thoughts on sor Juana that have as their aims not some speculative resolution of her enigma, but the transformation of that enigma into a strategy via which to read sor Juana's texts as a labyrinth—without the perception of what is "right" and what is "wrong". Yet, this does not imply a return to an empirical methodology that receives only from the experience the input to understand which is the right or the wrong move, but rather to recognize that even in the face of the densest Baroque text, there is the possibility to read that density without the need to overcome it by fixing 'meaning'.

The untranslatability of sor Juana's texts demonstrates precisely that writing retains materiality and signifiers that are impossible to translate into a new materiality 
without losing part of their meaning. Yet, far from being understood as a limitation, this poetic ambiguity has enabled me to dive into the research of new forms of approaching and approximation in which the text can remain untranslated, but can still communicate. This aspect of my research remains an only partially explored field that opens new roads in sor Juana's universe - a universe in continuous expansion that reassures me that the question "Why sor Juana, why today?" is a question with an endless number of answers which, as a consequence, makes sor Juana's corpus forever relevant and intriguing.

The act of avoiding categories and identities that typifies sor Juana's corpus, and that has been the main focus of this dissertation, reveals itself to be a powerful tool in the research of new reading methods, and also in the political praxis of a feminism that remains open to transgressions, alliances, and contaminations. As a consequence, the act of avoiding the trap of identity allows me to approach the literary text as a political instance. Due to this approach, the questions that open the chapters (who is the subject that speaks in sor Juana's texts; what is its sex; in which sense does it "exist"; and where does it exist) are no longer mere biographical curiosities. Rather, in the literary analysis, these questions transform the biographical into a stronger possibility of reclaiming, through the upheaval of the singularity, an in-between space that escapes identification. 


\section{Bibliography}

Abbagnano, N. (2006) Storia della Filosofia. 12 Voll. Roma, Italy: Gruppo Editoriale L'Espresso.

Abreu Gómez, E. (1934). Sor Juana Inés de la Cruz. Bibliografía y Biblioteca. Mexico D. F., Mexico: Monografías Bibliográficas Mexicanas.

Abreu Gómez, E. (1938). La ruta de sor Juana. Mexico City, Mexico: DAPP.

Aguirre Carreras, M. (1975). Del encausto a la sangre: Sor Juana Inés de la Cruz. Mexico City, Mexico: Larios e hijos impresores.

Anzaldúa, G. (1987). Borderlands/La Frontera. The New Mestiza. San Francisco, U.S.A.: Aunt Lute Books.

Apter, E. (2013). Against World Literature. On the Politics of Untranslatability. New York, U.S.A.: Verso.

Arango L, M. A. (2008). Tema y estructura en el teatro del siglo XVI y XVII en Hispanoamericana y España. Berlin, Germany: Peter Lang.

Arango L, M. A. (2000). Contribución al estudio de la obra dramática de Sor Juana Inés de la Cruz. New York, U.S.A.: Peter Lang.

Arenal, E. (2005). Del emblema al poema. Leyendo como una mujer la imagen de la mujer. In S. Lorenzano (Ed.), Aproximaciones a Sor Juana. (pp. 19-28). Mexico City, Mexico: Fondo de Cultura Económica. 
Arenal. E. (1985). Sor Juana Inés de la Cruz: Reclaiming the Mother Tongue. Letras Femeninas, $11(1 / 2), 63-75$.

Arenal, E. \& Powell, A. (1993). A Life Without and Within: Juana Ramírez/ Sor Juana Inés de la Cruz (1648/51-1695). Women's Studies Quarterly, 21(1/2), 67-80.

Arenal, E. \& Schlau S. (2010). Untold Sisters: Hispanic Nuns in Their Own Works. Albuquerque, U.S.A.: University of New Mexico Press.

Aristotle. (2011). De Anima. Translated with Introduction and Notes by Mark Shiffman. Newburyport, U.S.A.: Focus Publishing.

Arroyo Hidalgo, S. (1993). El Primero Sueño de Sor Juana: Estudio semántico y retórico. Mexico City, Mexico: Universidad Nacional Autónoma de México.

Augustine of Hippo. (1991) The Trinity, De Trinitate. Introduction, Translation, and Notes Edmund Hill. New York, U.S.A.: New City Press.

Austin, J. (1962). How To Do Things With Words. Oxford, United Kingdom: Oxford University Press.

Bellini, G. (1964). L'opera letteraria di Sor Juana Inés de la Cruz. Milano, Italia: Cisalpino.

Bellini, G. (1987). Sor Juana e i suoi misteri. Studio e testi. Milano, Italia: CisalpinoGoliardica.

Bénassy Berling, M.-C. (1982). Humanisme et religion chez Sor Juana Inés de la Cruz. Paris, France: Éditions Hispaniques. 
Benítez, F. (1985). Los demonios en el convento: sexo y religión en la Nueva España. Mexico City, Mexico: Ediciones Era.

Bergmann, E. L. (1993). Ficciones de Sor Juana: poética y biografía. In S. Poot Herrera, $Y$ diversa de mí misma entre vuestras plumas ando. Homenaje internacional a Sor Juana Inés de la Cruz, (pp. 171-184). Mexico City, Mexico: El Colegio de México.

Bosse, M., Potthast, B. \& Stoll A. (1999) La creatividad femenina en el mundo barroco hispánico. 2 Voll. Kassel, Germany: Edition Reichenberger.

Brading, D. A. (2015). La Nueva España. Patria y Religión. Mexico City, Mexico: Fondo de Cultura Económica.

Bravo Arriaga, M. D. (2005). Las loas de los autos de Sor Juana: los signos de la tolerancia. In S. Lorenzano (Ed.), Aproximaciones a Sor Juana. (pp. 55-64). Mexico City, Mexico: Fondo de Cultura Económica.

Broggio, P. (2004). Evangelizzare il mondo. Le Missioni della Compagnia di Gesú tra Europa e America (secoli XVI-XVII). Roma, Italy: Carocci Editore.

Burke, C. \& Irigaray, L. (1980). When Our Lips Speak Together. Signs: Journal of Women In Culture and Society, 6 (1), 69-79.

Butler, J. (1990). Gender Trouble. Feminism and the Subversion of Identity. New York, U.S.A.: Routledge

Butler, J. (1993). Bodies That Matter. On the Discursive Limits of Sex. New York, U.S.A.: Routledge. 
Butler, J. (2004). Undoing Gender. New York, U.S.A.: Routledge.

Butler, J. (2015). Senses of The Subject. New York, U.S.A.: Fordham University Press.

Butler, J. \& Malabou, C. (2016). Sois mon corps. Une lecture contemporaine de la domination et de la servitude chez Hegel. Montrouge, France: Bayard Editions.

Cassin, B. (ed.). (2004). Vocabulaire Européen des philosophies: Dictionnaire des intraduisibles. Paris, France: Seuil.

Cassin, B. (ed.). (2014). Dictionary of Untranslatables. A Philosophical Lexicon. Princeton, U.S.A.: Princeton University Press.

Cervantes, E. A. (2016). El testamento de Sor Juana Inés de la Cruz y otros documentos. Mexico City, Mexico: Frente de Afirmación Hispanista.

Charnon-Deutsch, L. (1992). Estudios sobre escritoras hispánicas en honor de Georgina Sabat-Rivers. Madrid, Spain: Editorial Castalia.

Cixous, H. \& Clément, C. (1986). The Newly Born Woman. Minneapolis, U.S.A.: Minnesota University Press.

Colombi, B. (2017). El Neptuno Alegórico de Sor Juana Inés de la Cruz: fábula clásica, emblemática y mitografía criolla. In B. Ventarola (Ed.), Ingenio y Feminidad: Nuevos enfoques en la estética de Sor Juana Inés de la Cruz. (pp. 71-98). Madrid/Frankfurt, Spain/Germany: Iberoamericana Vervuert.

Cortés Koloffon, A. (2013). Cósmica y Cosmética. Pliegues de la alegoría en Sor Juana Inés de la Cruz y Pedro Calderón de la Barca. Madrid, Spain: Iberoamericana Vervuert. 
Cruz, S. (1995). Juana Inés de Asuaje o de Asuage. El verdadero nombre de sor Juana. Puebla, Mexico: Universidad Autónoma de Puebla.

Cruz, Sor Juana Inés de la. (1951). Obras completas de Sor Juana Inés de la Cruz. I Lírica Personal. Edición, prólogo y notas de Alfonso Méndez Plancarte. Mexico City, Mexico: Fondo de Cultura Económica.

Cruz, Sor Juana Inés de la. (1952). Obras completas de Sor Juana Inés de la Cruz. II Villancicos y letras sacras. Edición, prólogo y notas de Alfonso Méndez Plancarte. Mexico City, Mexico: Fondo de Cultura Económica.

Cruz, Sor Juana Inés de la. (1955). Obras completas de Sor Juana Inés de la Cruz. III Autos y loas. Edición, prólogo y notas de Alfonso Méndez Plancarte. Mexico City, Mexico: Fondo de Cultura Económica.

Cruz, Sor Juana Inés de la. (1957). Obras completas de Sor Juana Inés de la Cruz. IV Comedias, sainetes y prosa. Edición, introducción y notas de Alberto G. Salceda. Mexico City, Mexico: Fondo de Cultura Económica.

Cruz, Sor Juana Inés de la. (1988). A sor Juana Anthology. Translated by Alan Trueblood. Cambridge, U.S.A.: Harvard University Press.

Cruz, Sor Juana Inés de la. (1994). The Answer/La Respuesta. Including a Selection of Poems. Critical Edition and Translation by Electa Arenal and Amanda Powell. New York, U.S.A.: The Feminist Press at the City University of New York.

Cruz, Sor Juana Inés de la. [1689] (1995). Inundación Castálida. Facsimilar Edition. Mexico City, Mexico: Universidad Nacional Autónoma de México. 
Cruz, Sor Juana Inés de la. [1692] (1995). Segundo volumen. Facsimilar Edition. Mexico City, Mexico: Universidad Nacional Autónoma de México.

Cruz, Sor Juana Inés de la. [1700] (1995). Fama y Obras pósthumas. Facsimilar Edition. Mexico City, Mexico: Universidad Nacional Autónoma de México.

Cruz, Sor Juana Inés de la. (2009). Obras completas de Sor Juana Inés de la Cruz. I Lírica Personal. Edición, prólogo y notas de Antonio Alatorre. Mexico City, Mexico: Fondo de Cultura Económica.

Cruz, Sor Juana Inés de la. (2018). Ecos de mi pluma. Antología en prosa y verso. Edición, prólogo, notas y cronología de Martha Lilia Tenorio. Mexico City, Mexico: Penguin Clásicos.

Cruz, Sor Juana Inés de la, \& Sayers Peden, M. (1987). A Woman of Genius. Salisbury, U.S.A.: Lime Rock Press.

Cruz, Sor Juana Inés de la, \& Tapia Méndez, A. (1981). Autodefensa espiritual de sor Juana. Monterrey, Mexico: Universidad Autónoma de Nuevo León.

Cruz, A. \& Hernández R. (ed.) (2011). Women's Literacy in Early Modern Spain and the New World. Farnham, U.K.: Ashgate Publishing.

Culler, J. (1975). Structuralist Poetics. London, United Kingdom: Routledge.

Culler, J. (2007). On Deconstruction. Theory and Criticism after Structuralism. Ithaca, U.S.A.: Cornell University Press. 
De Lauretis, T. (1990). Eccentric Subjects: Feminist Theory and Historical Consciousness. In Feminist Studies, 16 (1), 115-150.

Deleuze, G. (1988). Le Pli. Leibniz et le baroque. Paris, France: Les Éditions de Minuit.

Deleuze, G. (1993). The Fold. Leibniz and The Baroque. Minneapolis, U.S.A: The University of Minnesota Press.

Deleuze, G. (1995). Negotiations. New York, U.S.A.: Columbia University Press.

Deleuze, G. (2004). Desert Islands and Other Texts 1953 - 1974. Los Angeles, U.S.A.: Semiotext(e).

Derrida, J. (1967). De la Grammatologie. Paris, France: Les Éditions de Minuit.

Derrida, J. (1967). L'écriture et la difference. Paris, France: Seuil.

Derrida, J. (1974). Of Grammatology. Baltimore, U.S.A.: The Johns Hopkins University Press.

Derrida, J. (1976). Spurs. Nietzsche's style. Venezia, Italia: Corbo e Fiore Editori.

Derrida, J. (1983). Geschlecht: difference sexuelle, différence ontologique. In M. Haar (ed.), Les Cahiers de l'Herne Martin Heidegger, (pp. 571-595) Paris, France: L'Herne.

Derrida, J. (1987). Geschlecht II: La Main d'Heidegger. In J. Derrida, Psyché: Invenstions de l'autre. (pp. 415-452) Paris, France: Galilée.

Derrida, J. (1987). Psyché. Paris, France: Galilée. 
Derrida, J. (1993). Heidegger's ears: Philopolemology (Geschlecht IV). In J. Sallis (ed.), Reading Heidegger, (pp. 163-220). Bloomington Indianapolis, U.S.A.: Indiana University Press.

Derrida, J. (1993). Sauf le nom. Paris, France: Galilée.

Derrida, J. (1993). Spectres de Marx. Paris, France: Galilée.

Derrida, J. (1994). L'Oreille de Heidegger (Philopolémologie Geschlecht IV). In J. Derrida, Politiques de l'amitié. (pp. 343-419) Paris, France: Galilée.

Derrida, J. (1994). Politiques de l'amitié. Paris, France: Galilée.

Derrida, J. (1994). Specters of Marx. New York, U.S.A.: Routledge.

Derrida, J. (1995). On the Name. Stanford, U.S.A.: Stanford University Press.

Derrida, J. (2001). Writing and difference. New York, U.S.A.: Routledge.

Derrida, J. (2007). Learning to Live Finally...The Last Interview. Hoboken, U.S.A.: Melville House Publishing.

Derrida, J. (2008). Geschlecht I: Sexual Difference, Ontological Difference. In J. Derrida, Psyche. Inventions of the Other. Volume II. (pp. 7-26) Stanford, U.S.A.: Stanford University Press.

Derrida, J. (2008). Heidegger's Hand (Geschlecht II). In J. Derrida, Psyche. Inventions of the Other. Volume II. (pp. 27-62) Stanford, U.S.A.: Stanford University Press.

Derrida, J. (2008). Psyche. Inventions of the Other. Volume II. Stanford, U.S.A.: Stanford University Press. 
Derrida, J. (2013). Heidegger: la question de l'être et de l'histoire, Paris, France: Galilée.

Derrida, J. (2018). Geschlecht III. Sexe, race, nation, humanité. Paris, France: Seuil.

Derrida, J. (2020). Geschlecht III. Sex, race, nation, humanity. Chicago, U.S.A.: The University of Chicago Press.

Derrida, J. \& Ferraris, M. (1997). Il gusto del segreto. Bari, Italia: Editori Laterza.

Derrida, J. \& McDonald C., (1982). Interview: Choreographies: Jacques Derrida and Christie McDonald. Diacritics, 12 (2), 66-76.

Diccionario de Autoridades. Tomo I. (1726). Madrid, Spain: Real Academia Española.

Diccionario de Autoridades. Tomo II. (1729). Madrid, Spain: Real Academia Española.

Diccionario de Autoridades. Tomo III. (1732). Madrid, Spain: Real Academia Española.

Diccionario de Autoridades. Tomo IV. (1734). Madrid, Spain: Real Academia Española.

Diccionario de Autoridades. Tomo V. (1737). Madrid, Spain: Real Academia Española.

Diccionario de Autoridades. Tomo VI. (1739). Madrid, Spain: Real Academia Española.

Elliott, J. H. (1970). The Old World and The New. 1492 - 1650. Cambridge, U.K.: Cambridge University Press.

Elliott, J. H. (2009). Spain, Europe, and the Wider World. 1500 - 1800. London, U.K.: Yale University Press.

Exbalin, A. (2019). Des haillons et des perles. Images des inégalités socio-raciales en Nouvelles Espagne. In C. Lacaze, R. Soto-Quirós, \& R. J. Viales-Hurtado (eds.), Historia 
de las desigualdades étnico-raciales en México, Centroamérica y el Caribe (Siglos XVIIIXXI). San José, Costa Rica: Universidad de Costa Rica.

Fabre, L. F. \& Pluecker, J. (2015). Sor Juana \& Other Monsters. New York, U.S.A.: Ugly Duckling Press.

Field, A. M. (1988). The Origins of the Platonic Academy of Florence. Princeton, U.S.A.: Princeton University Press.

Foucault, M. (1970). The Order of Things. New York, U.S.A.: Pantheon Books.

Foucault, M. (1971). L'ordre du discours. Paris: France, Gallimard.

Foucault, M. (1976). La volonté de savoir. Paris: France, Gallimard.

Foucault, M. (2001). L'Herméneutique du sujet. Cours au Collège de France. 1981-1982. Paris, France: Gallimard Seuil.

Gaspar de Alba, A. (1999). Sor Juana's Second Dream. A Novel. Albuquerque: U.S.A.: University of New Mexico Press.

García-Ramos Merlo, J. (2020). El mito del Ave Fénix en la poesía barroca novohispana: influencias y relaciones comparadas. In S. Tedeschi, El largo viaje de los mitos. Mitos clásicos y mitos prehispánicos en las literaturas latinoamericanas, (pp. 27-46). Roma, Italia: Sapienza Università Editrice.

Giallongo, A. (2017). The Historical Enigma of the Snake Woman from Antiquity to the $21^{\text {st }}$ Century, Cambridge, United Kingdom: Cambridge Scholars Publishing. 
Giehlow, K. (2015). The Humanist Interpretation of Hieroglyphs in the Allegorical Studies of the Reinassance. Leiden, The Netherlands: Brill.

Gilbert, S. \& Gubar, S. (2000). The Madwoman in the Attic. The Woman Writer and the Nineteenth-Century Literary Imagination. Second Edition. Yale, U.S.A.: Yale Nota Bene.

Glantz, M. (2000). La comparación y la hipérbole. Mexico City, Mexico: Sello Bermejo.

Glantz, M. (2006). El cuerpo inscrito y el texto escrito o la desnudez como naufragio: Álvar Núñez Cabeza de Vaca. In M. Glantz, Obras reunidas I. Ensayos sobre literatura colonial, (pp. 86-116). Mexico City, Mexico: Fondo de Cultura Económica.

Glantz, M. (2006). El entorno de sor Juana. In M. Glantz, Obras reunidas I. Ensayos sobre literatura colonial, (pp. 472-484). Mexico City, Mexico: Fondo de Cultura Económica.

Glantz, M. (2006). Las finezas de sor Juana: Loa a El Divino Narciso. In M. Glantz, Obras reunidas I. Ensayos sobre literatura colonial, (pp. 472-484). Mexico City, Mexico: Fondo de Cultura Económica.

Glantz, M. (2006). Sor Juana: ¿Hagiografía o autobiografía? In M. Glantz, Obras reunidas I. Ensayos sobre literatura colonial, (pp. 215-340). Mexico City, Mexico: Fondo de Cultura Económica.

Gonzalbo Aizpuru, P. (ed.) (1991). Familias Novohispanas. Siglos XVI al XIX. Mexico City, Mexico: El Colegio de México.

Graff Zivin, E. (2018). Marrano Specter: Derrida and Hispanism. New York, U.S.A.: Fordham University Press. 
Grossi, V. (2007). Sigilososo v(u)elos epistemólogicos en Sor Juana Inés de la Cruz. Frankfurt - Madrid, Germany - Spain: Iberoamericana Vervuert.

Hankins, J. (2007) Cambridge Companion to Reinassance Philosophy. Cambridge, United Kingdom: Cambridge University Press.

Harvey, T. (2013). Figuring Modesty in Feminist Discourse Across Americas, 16331700. Farnham, U.K.: Ashgate Publishing.

Hierro Pérezcastro, G. (2005). Sor Juana y la filosofía en la universidad. In S. Lorenzano (Ed.), Aproximaciones a Sor Juana. (pp. 159-163). Mexico City, Mexico: Fondo de Cultura Económica.

Hill, R. (2000). Scepters and Sciences in the Spains. Cambridge, U.K.: Cambridge University Press.

Jakobson, R. (1984). Shifters, Verbal Categories, and the Russian Verb. In L. Waugh \& M. Halle (eds.), Russian and Slavic Grammar. Studies 1931-1981. (pp. 41-58). Berlin, Germany: Mouton Publishers.

Jones, J. (1979). "La erudición elegante": Observations on the Emblematic Tradition in Sor Juana's "Neptuno Alegórico" and Sigüenza's "Teatro de Virtudes Políticas". Hispanófila. 65 (Enero 1979), 43-58.

Kaiser, B. M. \& Thiele, K. (2017). "What is Species Memory? Or, Humanism, Memory and the Afterlives of 1492". Parallax, 23 (4), 403-415.

Kirby, V. (2009). “Tracing Life 'La Vie la Mort"”. The New Centennial Review. 9 (1), 107-126. 
Kirk, S. (2009). El parto monstruoso: creación artística y reproducción biológica en la obra de sor Juana Inés de la Cruz. Revista Iberoamericana, 75(227), 417-433.

Kirk, S. (2016). Sor Juana Inés de la Cruz and the Gender Politics of Knowledge in Colonial Mexico. New York, U.S.A.: Routledge.

Lacan, J. (1966). Écrits. Paris, France: Seuil.

Lacan, J. (2006). Le séminaire de Jacques Lacan livre XVI D'Un autre à l'autre, 19681969, Paris, France: Seuil.

La Maza, F. de (1980). Sor Juana Inés de la Cruz ante la historia. Mexico City, Mexico: Universidad Nacional Autónoma de México.

La Maza, F. de (1975). La ruta de Sor Juana de Nepantla a San Jerónimo. Mexico City, Mexico: Gobierno del Estado de México. Talleres Gráficos de la Nación.

Lavrin, A. (1991). Unlike Sor Juana? The Model of Nun in the Religious Literature of Colonial Mexico. In S. Merrim (ed.) Feminist Perspectives on Sor Juana Inés de la Cruz, (pp. 61-85), Detroit, U.S.A.: Wayne State University Press.

Leal, L. (1993). El hechizo derramado: elementos mestizos en Sor Juana. In S. Poot Herrera, Y diversa de mí misma entre vuestras plumas ando. Homenaje internacional a Sor Juana Inés de la Cruz, (pp. 185-200). Mexico City, Mexico: El Colegio de México.

Lizana Miranda, P. (2019). La poética o retórica subalterna en la loa El Divino Narciso de Sor Juana Inés de la Cruz. Alpha, 48, 37-53.

Long, P. H. (2009). Sor Juana/Música. Berlin, Germany: Peter Lang. 
López Cano, R. (2000). Música y retórica en el barroco. Mexico City, Mexico: Universidad Nacional Autónoma de México.

López-Portillo Romano, C. B. \& Lorenzano, S. (2005). Presentación. In S. Lorenzano (Ed.), Aproximaciones a Sor Juana. (pp. 7-8). Mexico City, Mexico: Fondo de Cultura Económica.

Luciani, F. (2004). Literary Self-Fashioning in Sor Juana Inés de la Cruz. Lewisburg, U.S.A.: Bucknell University Press.

Lugones, M. (1994). Purity, Impurity, and Separation. Signs, 19 (2), 458-479.

Lugones, M. (2007). Heterosexualism and the Colonial / Modern Gender System. Hypatia, 22 (1), 186-209.

Lugones, M. (2010). Toward a Decolonial Feminism. Hypatia, 25 (4), 742-759.

Malabou, C. (2011). Changing difference. Cambridge, United Kingdom: Polity.

Markey, L. (2016). Imagining the Americas in Medici Florence. Philadelphia, U.S.A.: Pennsylvania University Press.

Martín Jiménez, A. (2005). Cervantes y Pasamontes: la réplica cervantina al Quijote de Avellaneda. Madrid, Spain: Biblioteca Nueva.

Martínez, L. A. (2012). La Celda, el hábito y la evasión epistolar en sor Juana Inés de la Cruz. Revista chilena de literatura, 81, 69-89.

Maura, J. F. (2005). Españolas de Ultramar en la historia y en la literatura. Valencia, Spain: Universitat de Valencia. 
McKittrick, K. \& Wynter, S. (2015). Unparalleled Catastrophe for Our Species? Or, to Give Humanness a Different Future: Conversations. In K. McKittrick (ed.), Sylvia Wynter On Being Human as Praxis, (pp. 9-89). Durham, U.S.A.: Duke University Press.

Melville, H. (2002). Bartleby, the Scrivener. In Melville's Short Novels, (pp. 3-34) New York, U.S.A.: W.W. Norton \& Company

Merrim, S. (1999). Early Modern Women's Writing and Sor Juana Inés de la Cruz. Nashville, U.S.A.: Vanderbilt University Press

Merrim, S. (ed.) (1991). Feminist Perspectives on Sor Juana Inés de la Cruz. Detroit, U.S.A.: Wayne State University Press.

Merrim, S. (1991). Toward a Feminist Reading of Sor Juana Inés de la Cruz: Past, Present, and Future Directions in Sor Juana Criticism”. In S. Merrim (ed.) Feminist Perspectives on Sor Juana Inés de la Cruz, (pp. 11.37). Detroit, U.S.A.: Wayne State University Press.

Moi, T. (2002). Sexual/textual politics. London, United Kingdom: Routledge.

Muriel de la Torre, J. (1946). Conventos de Monjas en la Nueva España. Mexico City, Mexico: Editorial Santiago.

Muriel de la Torre, J. (1982). Cultura Femenina Novohispana. Mexico City, Mexico: Universidad Nacional Autónoma de México.

Muriel de la Torre, J. (1992). Las mujeres de Hispanoamérica: época colonial. Mexico City, Mexico: MAPFRE Editorial.

Nancy, J.-L. (2000). Corpus. Paris, France: Métailiée 
Nancy, J.-L. (2001). L' “il y a” du rapport sexual. Paris, France: Galilée.

Nancy, J.-L. (2017). Sexistence. Paris, France: Galilée.

New Oxford American Dictionary. (2010) Oxford, United Kingdom: Oxford University Press.

Ovid. (2008). Metamorphoses. Oxford, United Kingdom: Oxford University Press.

Hoad, T. F. (2002). Oxford Concise Dictionary of English Etymology. Oxford, United Kingdom: Oxford University Press.

Pascual Buxó, J. (2002). El resplandor intelectual de las imágenes. Estudios de emblemáticas y de literatura novohispana. Mexico City, Mexico: Universidad Nacional Autónoma de México.

Pascual Buxó, J. (1993). El enamorado de sor Juana. Mexico City, Mexico: Universidad Nacional Autónoma de México.

Paz, O. (1982). Sor Juana Inés de la Cruz, o las trampas de la fe. Mexico City, Mexico: Fondo de Cultura Económica.

Paz, O. (1988). Sor Juana, or The Traps of Faith. Cambridge, U.S.A.: Harvard University Press.

Perelmuter, R. (2004). Los límites de la femineidad en Sor Juana Inés de la Cruz: estrategias retóricas y recepción literaria. Madrid, Spain: Iberoamericana Vervuert.

Pérez-Amador Adam, A. (2007). La ascendente estrella. Madrid, Spain: Iberoamericana Vervuert. 
Pérez Martínez, H. (2012). Sor Juana Inés de la Cruz. Una poesía al crisol de la vida. Ciudad Juárez, Mexico: Universidad de Ciudad Juárez.

Pfandl, L. (1963). Sor Juana Inés de la Cruz, la décima musa de México. Mexico City, Mexico: Universidad Nacional Autónoma de México.

Plato, (2008). The Symposium. Edited by M. C. Howatson \& F. C. C. Sheffield. Translated by M. C. Howatson. Cambridge, United Kingdom: Cambridge University Press.

Plato, (2009). Timaeus and Critias. A New Translation by Robin Waterfield. Oxford, United Kingdom: Oxford University Press.

Ponzio, A. (1993). Signs, Dialogue and Ideology. Amsterdam/Philadelphia, The Netherlands/U.S.A.: John Benjamins Publishing Company.

Poot Herrera, S. (ed.) (1995) Sor Juana y sum undo. Una mirada actual. Mexico City, Mexico: Universidad del Claustro de Sor Juana.

Prendergast, R. (2007). Constructing an Icon: the Self-Referentiality and Framing Sor Juana Inés de la Cruz. Journal for Early Modern Cultural Studies, 7 (2), 28-56.

Puccini, D. (1996). Una donna in solitudine. Bologna, Italy: Cosmopoli Editore.

Remes, P. (2005). Neoplatonism. Berkeley, U.S.A.: University of California Press.

Rosenblat, A. (1965). El Castellano de España y el Castellano de América. Unidad y diferenciación. Caracas, Venezuela: Universidad Central de Venezuela. 
Rubial García, A. (2005). La patria criolla de Sor Juana y sus contemporáneos. In S. Lorenzano (Ed.), Aproximaciones a Sor Juana. (pp. 347-370). Mexico City, Mexico: Fondo de Cultura Económica.

Sabat de Rivers, G. (1998). En busca de sor Juana. Mexico City, Mexico: Universidad Nacional Autónoma de México.

Sabat de Rivers, G. (1976). El "Sueño" de Sor Juana Inés de la Cruz. Tradiciones literarias y originalidad. London, U.K.: Támesis.

Sánchez Robayna, A. (1989). Para leer "Primero Sueño” de Sor Juana Inés de la Cruz. Mexico City, Mexico: Fondo de Cultura Económica.

Saussure, F. de. (1971). Cours de Linguistique Générale. Paris, France: Payot.

Schons, D. (1926). "Some Obscure Points in the Life of Sor Juana Inés De La Cruz". Modern Philology. Vol. 24, No. 2. pp. 141-162.

Sharma, N. (2015). Strategic Anti-Essentialism: Decolonizing Decolonization. In K. McKittrick (ed.), Sylvia Wynter On Being Human as Praxis, (pp. 164-182). Durham, U.S.A.: Duke University Press.

Solodkow, D. (2009). Mediaciones del yo y monstruosidad: sor Juana o el "fénix" barroco. Revista Chilena de Literatura, 74, 139-167.

Stevens. (1726). A New Dictionary. Spanish and English and English and Spanish, London, United Kingdom. 
Stivale, C. (1998). The two-fold thought of Deleuze and Guattari. New York, U.S.A.: Guilford Press.

Tenorio, M. L. (1999). Los villancicos de Sor Juana. Mexico City, Mexico: Colegio de México.

Various Authors. (1953). Musique et poésie au XVI siècle. Paris, France: Centre Nationale de la Recherche Scientifique

Wynter, S. (1991). Columbus and the Poetics of the Propter Nos. Annals of Scholarship, $8(2), 251-286$.

Wynter, S. (1995). 1492: A New World View. In V. Lawrence Hyatt \& R. Nettleford (eds.), Race, Discourse, and the Origin of the Americas: A New World View, (pp. 5-57). Washington, U.S.A.: Smithsonian Institution Press.

Wynter, S. (2003). Unsettling the Coloniality of Being/Power/Truth/Freedom. Toward the Human, After the Man, Its Overrepresentation - An Argument. The New Centennial Review, 3 (3), 257-337.

Yugar, T. (2014). Sor Juana Inés de la Cruz. Feminist Reconstruction of Biography and Text. Eugene, U.S.A.: Wipf \& Stock 


\section{Short biography}

Valeria Stabile was born in Castrovillari, Italy on December 29, 1985. In 2011 she obtained her bachelor's degree in Linguistics, European and Extra European Languages at the University of Pisa in Pisa, Italy with laude. In 2015 she earned a second bachelor's degree in Harpsichord and Early Keyboards at the Conservatorio "N. Piccinni" in Bari, Italy. In 2017 she graduated with laude from the Erasmus Mundus Programme GEMMA Master's Degree in Woman's and Gender Studies at the University of Bologna and at the Utrecht University. In 2017 she started her Ph.D. at the University of Bologna in cotutelle with the Utrecht University under the supervision of Prof. dr. Rosemarie Buikema, Pr., dr. María José Rodrigo Mora, dr. Kathrin Thiele, Prof. dr. Edoardo Balletta and Prof. dr. Gilberta Golinelli. She presented as speaker in several international conferences about the topics of feminist research and perspectives on literature, on sor Juana's corpus, and on gender studies.

Publications:

Stabile, V., “1968-2018. Tlatelolco fifty years after” In Performing Memories: Media, Creation, Anthropology, and Remembrance edited by Gabriele Biotti, Cambridge Scholars Publishing, Newcastle upon Tyne, 2021, pp. 102-116.

Stabile, V., "Autobiografía y heterofagia: la alimentación como espacio de reconocimiento del cuerpo en sor Juana Inés de la Cruz", in Postfilosofie. Rivista di pratica filosofica e scienze umane, Anno 12. Numero12 (2019). "Le rivoluzioni dell'alterità', pp. 206-221. 
Stabile, V., Translation of: "Sessistenza, una teoria dell'ontologia sessuale" di Emily Apter, in L'indice dei Libri del Mese N. 42019 Anno XXXVI Speciale "Festival delle Donne e dei Saperi di Genere", p. III

Stabile, V., "Dis-Tanz. Una riflessione su femminile ed elettricità a partire Da Apuntes para una declaración de fe di Rosario Castellanos" In Cultura \& Comunicazione, Anno IX n. 14 - Maggio 2019, Guerra edizioni, ISBN 978-88-557-0634-6

Stabile, V., “"En mi lengua': il gioco delle immagini e delle parole in La Celestina di Fernando de Rojas", in L'IMMAGINE NELLA PAROLA, NELLA MUSICA E NELLA PITTURA a cura di Susan Petrilli, Mimesis/ ATHANOR. SEMIOTICA, FILOSOFIA, ARTE, LETTERATURA Collana diretta da Augusto Ponzio n.s. XXVIII, 21, 257-270

Stabile, V., “«Made up of so many different parts»: alla ricerca dell’alterità nelle parole di Audre Lorde", in Postfilosofie. Rivista di pratica filosofica e scienze umane, Anno 11. Numero11 (2018) “Teorie femministe e saperi di genere. Nel segno di Audre Lorde”, pp. $48-55$.

Stabile, V., "Intorno al genere”, in: Postfilosofie. Rivista di pratica filosofica e scienze umane, Anno 11. Numero11 (2018) “Teorie femministe e saperi di genere. Nel segno di Audre Lorde", pp. 152-155.

Stabile, V., "Velar las palabras, callar las heridas. La memoria de la guerra francoargelina en la producción de Assia Djebar./ Veiling voices, silencing wounds. The 
memory of the French Algerian war in Assia Djebar's production", in Estudios Humanísticos. Filología 39 (2017) 107-123 (ISSN 0313-1329)

Stabile, V., "C.R.Stimpson G.Herdt Critical terms for the study of gender 2014 The University of Chicago Press 557 (ISBN 978-0-226-77481-7)" in: Women's Studies International Forum Vol. 63, Elsevier, 2017, (ISSN 0277-5395) 